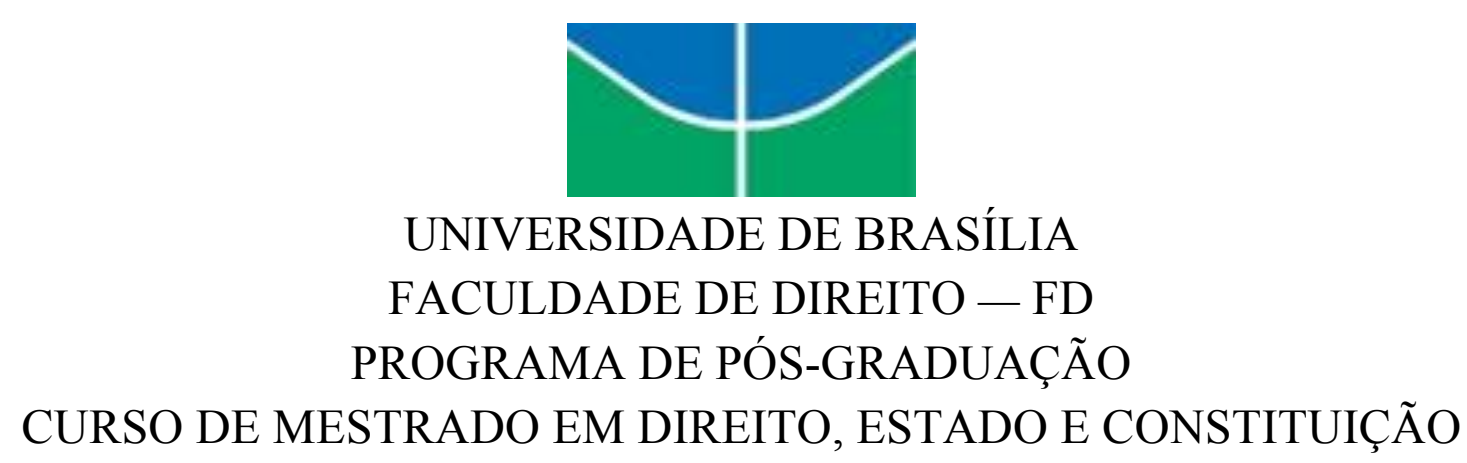

ENTRE VULNERABILIDADES PRESUMIDAS E A OCULTAÇÃO DE VOZES: TRAMAS DISCURSIVAS NAS DECISÕES DO JUDICIÁRIO BRASILEIRO SOBRE TRÁFICO INTERNACIONAL DE MULHERES CISGÊNERO

Raquel Negreiros Silva Lima

Brasília

2016 


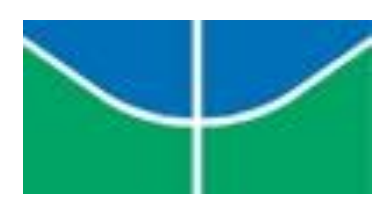

RAQUEL NEGREIROS SILVA LIMA

\title{
ENTRE VULNERABILIDADES PRESUMIDAS E A OCULTAÇÃO DE VOZES: TRAMAS DISCURSIVAS NAS DECISÕES DO JUDICIÁRIO BRASILEIRO SOBRE TRÁFICO INTERNACIONAL DE MULHERES CISGÊNERO
}

\author{
Dissertação apresentada ao Programa de Pós- \\ Graduação em Direito da Universidade de Brasília \\ como requisito para a obtenção do grau de Mestre \\ Área de concentração: Direito, Estado e \\ Constituição \\ Linha de pesquisa 1: Sociedade, conflito e \\ movimentos sociais \\ Orientadora: Prof $\stackrel{\text { a }}{\text {. Dr }}$ - Ela Wiecko Volkmer de \\ Castilho
}

\section{Brasília}




\title{
FOLHA DE AVALIAÇÃO
}

\author{
RAQUEL NEGREIROS SILVA LIMA
}

ENTRE VULNERABILIDADES PRESUMIDAS E A OCULTAÇÃO DE VOZES: TRAMAS DISCURSIVAS NAS DECISÕES DO JUDICIÁRIO BRASILEIRO SOBRE TRÁFICO INTERNACIONAL DE MULHERES CISGÊNERO

Após sessão pública de defesa desta dissertação para a obtenção do título de Mestre em Direito, a candidata foi considerada aprovada pela banca examinadora.

Brasília, 17 de março de 2016.

BANCA EXAMINADORA
Orientadora: Professora Doutora Ela Wiecko Volkmer de Castilho (Faculdade de Direito, UnB)

Professor Doutor José Geraldo de Sousa Junior (Membro interno: Faculdade de Direito, UnB)

Professora Doutora Thamara Duarte Cunha Medeiros (Membro externo: Universidade Estadual da Paraíba, UEPB, e Tribunal de Justiça do Estado de São Paulo, TJSP)

Professora Doutora Marcia Anita Sprandel (Membro Suplente: Senado Federal) 
A Neusa Negreiros e Raimunda Lima (in memoriam), minhas avós, mulheres que moram em mim. 


\section{AGRADECIMENTOS}

É uma oportunidade extremamente feliz poder expressar gratidão por todas aquelas pessoas que nos antecederam ou por nós passaram, contribuindo para o processo permanente de construção da nossa subjetividade, da forma como nos enxergamos e nos posicionamos no mundo.

Nominar, em poucas linhas, quem favoreceu a elaboração dessa dissertação é, no mínimo, um exercício injusto. Não há espaço para descrever a magnitude do sentimento de gratidão que tenho pelas pessoas que, antes mesmo de o mestrado começar, participaram da gestação deste meu projeto pessoal e acadêmico. Agradeço com o mais profundo afeto a todas aquelas pessoas que me incentivaram em algum momento a seguir para o mestrado; durante o curso e a escrita da dissertação me estimularam a prosseguir; escutaram minhas lamentações, inseguranças e angústias; seguraram a minha mão quando pensei que não seria possível concluir a tempo; compreenderam minhas ausências e me estimularam a ver o mestrado não apenas como dever e desafio, mas como oportunidade de amadurecer e ampliar o autoconhecimento.

Sou grata aos meus pais, Aurélio e Neusanir, e à minha irmã, Rejane. Simplesmente não há palavras para exprimir o que significam para mim. Amo vocês! Essa dissertação só existe porque tive amor e apoio incondicional de vocês três. Agradeço, ainda, a todos os meus familiares, tios e tias, primos e primas e à minha madrinha, Rosângela.

Ao Cassio, que dedicadamente me acompanhou, entre meus sorrisos e lágrimas, rumo à concretização deste sonho, o meu agradecimento carinhoso.

Homenageio todos os meus amigos e todas as minhas amigas, de perto e de longe, os de longa data e os mais recentes, porque estão em mim, e a força da amizade e do amor tem o poder de nos mover adiante. Um livro seria pouco para registrar todos os motivos pelos quais agradeço a cada um de vocês por existirem na minha vida.

Deixo aqui o meu especial agradecimento à Gabi, à Cida, ao Bruno e à Vanessa, que me apoiaram com muito carinho durante este tempo e seguraram as pontas comigo. Vocês são incríveis!

À Philippa, agradeço não só pela ajuda com o abstract, mas também por uma infinidade de razões que só uma amizade que tem idioma próprio - Raquipa - explica. 
Às pessoas queridas da PGR - inclusive as que já saíram para alçar novos voos, cada vez mais altos e belos -, muito obrigada pelo apoio. É uma alegria poder conviver e aprender, diariamente, com vocês.

À Fabiana Gorenstein, à Talitha Selvati, muito obrigada pela generosidade de me auxiliarem na elaboração do projeto de mestrado e do texto da dissertação. Foi seguindo os passos trilhados por vocês que pude alcançar os frutos desta pesquisa.

Ao pessoal da secretaria da Faculdade de Direito, em especial à Euzilene, agradeço por todo o empenho em me auxiliar ao longo da jornada no mestrado.

Agradeço a minha orientadora pela forma acolhedora como me direcionou durante a realização da pesquisa. Quando me perdi, foi ela quem me ajudou a retomar o foco. Em meio às inseguranças, esteve presente e fez-me sentir mais forte para produzir e defender o meu estudo. Muito obrigada, professora Ela Wiecko, fui muito agraciada por poder contar com a sua sensibilidade e experiência nesta jornada.

À professora Thamara Duarte Cunha Medeiros, agradeço a gentileza e a disponibilidade de vir de longe para contribuir com esta pesquisa, como membro avaliador da banca. Gentilmente agradeço, igualmente, a Marcia Anita Sprandel por aceitar integrar o corpo avaliador deste estudo, participando como membro arguidor na banca, e à Lúcia Gonçalves de Freitas, por ter avaliado carinhosamente o trabalho na forma de parecer, especialmente sob o aspecto da metodologia empregada.

Ao professor José Geraldo, o meu mais sincero obrigada, por quase uma década de inspiração e apoio. "O Direito Achado na Rua" é a minha lente para a compreensão do Direito como "modelo avançado de legítima organização social da liberdade", nas palavras de Lyra Filho. Foi na busca de um maior protagonismo das mulheres, como sujeitos de direitos, e de uma linguagem emancipadora que esta pesquisa foi conduzida. Suas lições, professor, são alicerce e combustível para essa vontade de transformar a realidade em prol de uma cultura de cidadania, igualdade de gênero e direitos humanos. 
Mulher da Vida, minha Irmã.

De todos os tempos.

De todos os povos.

De todas as latitudes.

Ela vem do fundo imemorial das idades e carrega a carga pesada dos mais torpes sinônimos, apelidos e apodos: Mulher da zona, Mulher da rua, Mulher perdida, Mulher à-toa.

Mulher da Vida, minha irmã.

(Cora Coralina) 


\section{RESUMO}

A presente dissertação trata do discurso jurídico-penal brasileiro sobre as mulheres cisgênero em processos sobre tráfico internacional de pessoas para a exploração sexual. Busca responder à inquietação sobre se são consideradas e ouvidas as vozes das mulheres nos processos selecionados, seja quando ocorre a migração livre para a prostituição, seja nos casos em que tem vez a exploração sexual. A pesquisa, de metodologia qualitativa, apoia-se na epistemologia feminista, contraposta ao saber androcêntrico e cis-heteronormativo que rege a racionalidade contemporânea ocidental. Utiliza como método a análise do discurso, com amparo em documentos contidos na base de dados do Escritório das Nações Unidas Contra Drogas e Crime - UNODC. Examina o papel do discurso judiciário na redução das assimetrias de gênero. Aborda a moralidade intrínseca às narrativas pró-abolicionismo da prostituição e mergulha em busca de caminhos que permitam repensar a linguagem utilizada no enfrentamento ao tráfico de mulheres cisgênero para fins de exploração sexual.

Palavras-chave: tráfico de pessoas, mulheres cisgênero, discurso penal, narrativas, prostituição, exploração sexual. 


\begin{abstract}
This dissertation evaluates Brazilian judicial discourse for cisgender women subjected to international people trafficking for sexual exploitation. It seeks to understand if the voices of the women involved are considered and heard during the judicial process, both in cases of free migration for prostitution and when sexual exploitation occurs. This qualitative research is based on feminist epistemology, which opposes the androcentric cisgender heteronormativity that dominates the contemporary Western rationality. The investigation uses discourse analysis (DA) as a method, based on documents presented in the United Nations Office on Drugs and Crime - UNODC Case Law Database. This study also examines the role of Brazilian law in reducing gender disparities. It reflects on the intrinsic morality of the arguments which favour the abolishment of prostitution, and searches for ways in which to instigate a review of the current language used with regards to the trafficking of cisgender women for sexual exploitation.
\end{abstract}

Keywords: human trafficking, cisgender women, criminal discourse, narratives, prostitution, sexual exploitation. 


\section{RESUMEN}

La tesina aborda el discurso jurídico penal brasileño sobre la mujer cisgénero en los procesos sobre trata internacional de personas para explotación sexual. Pretende dar respuesta a la inquietud acerca de si son consideradas y escuchadas las voces de las mujeres en las decisiones examinadas, sea cuando hay migración libre para la prostitución o cuando ocurre la explotación sexual. La investigación, de metodología cualitativa, se basa en la epistemología feminista, en oposición al conocimiento androcéntrico y cis-heteronormativo que rige la racionalidad contemporánea occidental. Utiliza como método el análisis del discurso, amparada en la base de datos de la Oficina de Naciones Unidas contra la Droga y el Delito UNODC. Examina el papel del discurso jurídico en la reducción de las disparidades de género. Reflexiona sobre el componente moral que integra las narrativas sobre el abolicionismo de la prostitución en busca de caminos que permitan repensar el lenguaje utilizado en la trata de mujeres cisgénero para explotación sexual.

Palabras clave: trata de personas, mujeres cisgénero, discurso penal, narrativas, prostitución, explotación sexual. 


\section{SUMÁRIO}

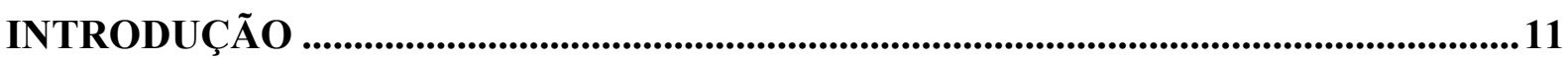

1 EPISTEMOLOGIAS E METODOLOGIAS POR UM DISCURSO FEMINISTA.... 19

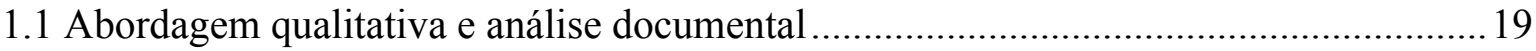

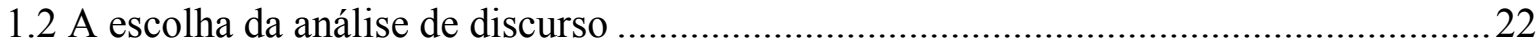

1.3 Bases por uma epistemologia feminista e crítica ao sistema andro-cis-heteronormativo

1.4 Política de conhecimento: minha perspectiva e lugar de fala como pesquisadora e o espaço político da investigação

2 ESTEREÓTIPOS E VIOLÊNCIAS NO DISCURSO JUDICIAL BRASILEIRO ....37 2.1. O tráfico de pessoas sob o prisma dos diplomas normativos nacionais e internacionais

2.2 O marco brasileiro de enfrentamento ao tráfico de pessoas . 46

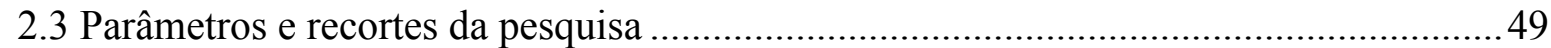

2.4 Validade, confiabilidade e consistência do projeto investigativo...................................52

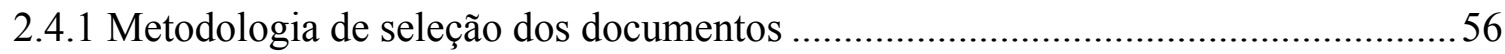

2.5 Análise do corpus documental e achados de pesquisa .............................................61

3 TRÁFICO INTERNACIONAL DE MULHERES: MIGRAÇÃO, SEXUALIDADE E DISCURSO JURÍDICO-PENAL. POR UMA NOVA LINGUAGEM DE PROTEÇÃO DO FEMININO NA SOCIEDADE PÓS-COLONIAL ...................................................75

$3.1 \mathrm{O}$ cenário brasileiro do tráfico de mulheres cis: uma realidade ainda pouco conhecida 75

3.2 A prostituição como objeto histórico de combate

3.3 Possibilidades de aproximação pós-colonial e feminista sobre a questão do tráfico internacional de mulheres cisgênero para fins de exploração sexual: sobre a limitação do discurso penal repressivo e a necessidade de reinvenção humanista do projeto de proteção da mulher 102

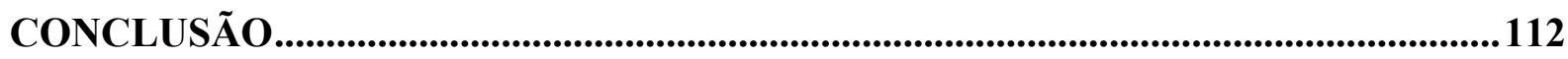

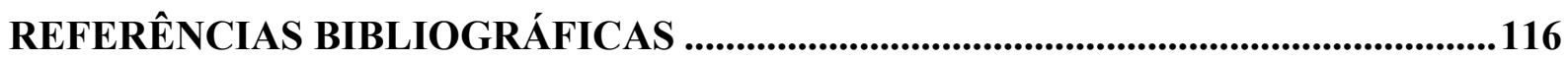

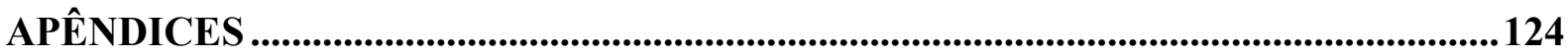

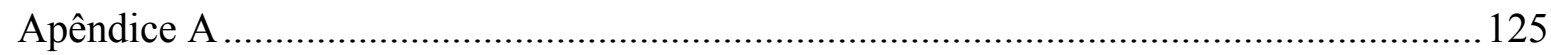

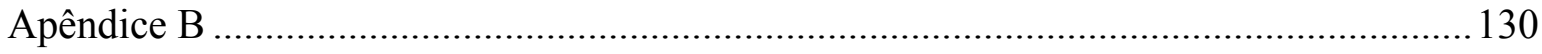

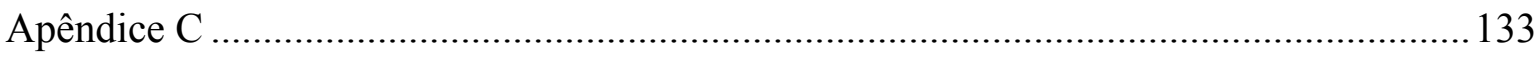

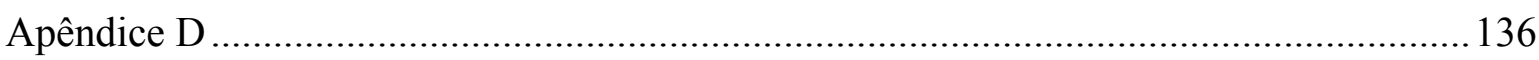

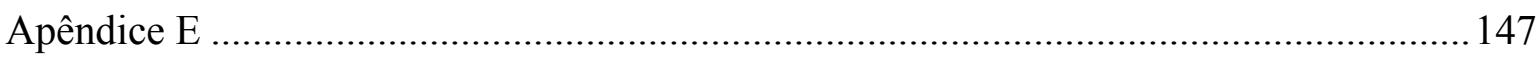




\section{INTRODUÇÃO}

Escrevo no feminino e em primeira pessoa.

O uso do feminino corresponde à identidade de gênero que performatizo no dia a dia. Não deixa de ser também uma escolha que homenageia todas as múltiplas formas do "ser mulher" em um mundo ainda dominado por uma lógica androcentrista, que se pretende universal, mas mostra sua face excludente ao relegar a uma posição de subalternidade o conjunto de caracteres que integram a noção difusa, etérea, complexa do "ser mulher"1.

Mulher branca, parda, negra. Pobre, rica. Cis, Trans. Nacional, estrangeira. Heterossexual, bissexual, homossexual. Europeia, latina, asiática, africana. Índia, quilombola, ribeirinha. A pesquisa é uma deferência a todas as formas e papeis assumidos pela mulher no contexto das relações sócio-político-jurídicas de poder. A investigação participa do movimento de luta por uma nova lógica discursiva, subversiva das estruturas edificadas que subjugam o feminino.

Peço perdão e desde já me redimo se, em algum trecho do texto, passar uma impressão essencialista ou simplificadora da noção de mulher, o que não é minha intenção. O uso do vocábulo foi eleito em função da carga semântica da palavra no Brasil. O termo, embora aparentemente simplificador, também pode ser utilizado como marco de uma identidade que trabalha para desfazer as amarras de uma dominação histórica.

Falar em primeira pessoa foi a forma mais transparente que encontrei de, sem jamais apartar-me da identidade feminina, evidenciar que o estudo que segue, assim como toda a produção científica, não tem pretensões de neutralidade. Pelo contrário. Faz parte de um projeto militante de produção de conhecimento engajado e teoria crítica, por alguém que se considera mulher e para todas aquelas pessoas que, assim como a eu-pesquisadora, identificam-se dentro desse mesmo universo do ser.

O uso do masculino foi guardado, ao longo de todo o texto, para os momentos em que atribuir ao gênero feminino certas atitudes seria incongruente, por razões fáticas ou políticas.

É o caso do emprego da palavra magistrado. A magistratura brasileira é majoritariamente masculina. O Poder Judiciário, como estrutura fundamental de Poder, ainda reproduz, no Brasil, uma consciência androcêntrica. Esse é o retrato que a documentação

1 Utilizo a expressão, mesmo reconhecendo que a própria noção da existência de um "ser mulher" seja limitada e controversa, nos dias de hoje, como bem nos fala Donna Haraway em seu Manifesto Ciborgue (2009). 
investigada pinta. E, mesmo nos raros casos analisados que foram julgados por magistradas do gênero feminino, o discurso dominador e de subjugação dos corpos femininos permaneceu latente. Merece, portanto, ser atribuído ao gênero masculino o extrato das decisões judiciais examinadas ${ }^{2}$.

Coloco que a ausência da pretensão de verdade e universalidade não invalida o método ou a produção do conhecimento. Apenas admito a consciência do meu lugar de fala, de ser mulher, heterossexual, parda, latina, e com isso construo conhecimento, à luz de uma epistemologia feminista que se ampara em uma visão pluriversal de mundo.

Neste estudo falo sobre tráfico de pessoas, migração, prostituição, mas o cerne da investigação está nas narrativas judiciais sobre as mulheres cisgênero, que, acredito, refletemse de alguma forma também no mundo das mulheres transgênero, por serem narrativas que repousam sobre a esfera do feminino.

Por cis ou cisgênero, refiro-me às pessoas que performam suas identidades de acordo com o sexo que lhes foi atribuído ao nascer. Cis significa "do mesmo lado" e, nessa esteira, a mulher cisgênero é aquela que nasceu com órgãos sexuais femininos e se expressa socialmente no feminino. Não performatiza, portanto, sua identidade de acordo com o masculino, o que denotaria uma opção pela transgeneridade.

Já a transgeneridade é aqui compreendida como terminologia ampla que pretende abarcar todas as variações de gênero que não se encaixam no paradigma binário do feminino e do masculino, de acordo com o sexo atribuído no nascimento. Dentro desse termo guardachuva, há duas classificações mais notoriamente conhecidas, quais sejam, a de travestis e transexuais. Sem embargo, essas duas categorias estão longe de alcançar a complexidade das diferentes performances de gênero possíveis. O campo político pelo reconhecimento de novas modalidades de identificação de gênero está em aberto.

Enveredo pelo discurso do Judiciário Brasileiro sobre o tráfico de mulheres cisgênero. O faço com base nas sentenças e nos acórdãos em apelações criminais que o Brasil, por intermédio do Conselho Nacional de Justiça, enviou ao Escritório das Nações Unidas contra Drogas e Crime - UNODC ${ }^{3}$, até o mês de dezembro de 2015. De um total de 81 decisões,

2 Registro que apenas os Documentos 8, 12, 16 e 21, do Apêndice B, trazem a identificação da julgadora como juíza, no feminino.

3 Escritório responsável pelo acompanhamento da observância dos protocolos acessórios à Convenção contra o Crime Organizado Transnacional, entre eles, o Protocolo Adicional à Convenção das Nações Unidas contra o Crime Organizado Transnacional Relativo à Prevenção, Repressão e Punição do Tráfico de Pessoas, em Especial Mulheres e Crianças (Palermo, Nações Unidas, 2003). 
restaram 36 após a exclusão dos documentos que não apresentavam elementos consistentes para a análise do discurso - dentre eles Habeas Corpus, Revisões Criminais e Recursos em Sentido Estrito -, bem assim daqueles que faziam referência a tráfico de crianças e adolescentes ou a aliciamento de trabalhadores para fim de emigração.

A curiosidade pelo material foi intuitiva. Partiu da expectativa de nele encontrar potencial substantivo a respeito das relações de gênero e dos pilares da construção social do conceito de tráfico de pessoas nas narrativas do Judiciário. $\mathrm{O}$ exame das decisões foi feito à luz dos parâmetros conceituais do que seja tráfico de pessoas contidos no Protocolo Adicional à Convenção das Nações Unidas contra o Crime Organizado Transnacional, também conhecido como Protocolo de Palermo (NAÇÕES UNIDAS, 2003). De acordo com esse diploma normativo, tráfico de pessoas é "o recrutamento, o transporte, a transferência, o alojamento ou o acolhimento de pessoas, recorrendo à ameaça ou ao uso da força ou a outras formas de coação, ao rapto, à fraude, ao engano, ao abuso de autoridade ou de situação de vulnerabilidade ou à entrega ou aceitação de pagamentos ou benefícios para obter o consentimento de uma pessoa que tem autoridade sobre outra, para fins de exploração" (NAÇÕES UNIDAS, 2003).

Palermo surge como instrumento internacional em nome da (i) prevenção e do combate ao tráfico de pessoas, com atenção especial às mulheres e às crianças; (ii) proteção e ajuda às vítimas desse tráfico, com respeito pleno aos seus direitos humanos; e (iii) promoção da cooperação entre os Estados-Partes para atingir os dois primeiros objetivos.

Como se depreende dos escopos indicados, mulheres e crianças recebem especial atenção dentro da temática do tráfico de pessoas. Sobeja dos objetivos do Protocolo a noção de que mulheres e crianças são especialmente vulneráveis ao problema. Será esta uma impressão que corresponde à realidade? Temos dados para atestar que sim? A investigação caminha por aí. Propõe-se a questionar, inclusive, em que medida a atribuição da qualidade de vítima às mulheres migrantes não gera o efeito perverso de esvaziar a potência, a capacidade de agir, dessas pessoas como sujeitos de direitos.

Destaco que o próprio uso do termo vítima, ao longo do texto, foi feito em razão de ser esse o vocábulo empregado pelo Protocolo de Palermo e pelo Judiciário Brasileiro nas decisões analisadas. Reconheço, porém, a limitação dessa palavra para expressar as diferentes experiências migratórias incorporadas no discurso corrente sobre tráfico de pessoas e a necessidade de leitura crítica dos sentidos que veicula. 
Com a noção de que as mulheres estão no centro das políticas de enfrentamento ao tráfico de pessoas, tomei como rumo a análise das decisões brasileiras disponibilizadas na base de dados do UNODC. A aproximação ainda superficial daqueles julgados dava a dimensão de que a quantidade de casos de tráfico de pessoas para fins de exploração sexual era sensivelmente superior àquela encontrada nos casos de adoção para tráfico de crianças ou de aliciamento mediante fraude para trabalho no exterior e, forte nesta pressuposição, conduzi a investigação.

Despertou em mim a curiosidade de entender o que esse conjunto maior de dados sobre tráfico de pessoas para exploração sexual dizia sobre as mulheres que supostamente foram traficadas. Ao mesmo tempo, tive a noção de que a inclusão de mulheres transgênero na análise exigiria uma abordagem diferenciada, que fosse capaz de acompanhar os matizes que a imagem da mulher transgênero migrante carrega. Ao mesmo tempo em que performatiza o feminino, a mulher trans tem em sua história elementos masculinos. Portanto, a mescla dos casos referentes a mulheres cis e trans poderia vir, eventualmente, a poluir os dados sobre a narrativa do Judiciário Brasileiro sobre migração, liberdade, autonomia e violência no feminino.

A par dessas ponderações, pensei em separar os casos de mulheres trans para um estudo ulterior, que viesse a complementar o presente. Qual não foi a minha descoberta? De que sobre tráfico de mulheres trans havia na base de dados apenas Habeas Corpus, espécie de ação constitucional essencialmente fundada no direito de liberdade e que não oferece cognição horizontal mais profunda sobre a matéria discutida no processo penal principal. Notei, ali, que havia um silêncio eloquente sobre o tráfico de mulheres transgênero. Estariam elas invisibilizadas pelo discurso hegemônico do tráfico? Ou os casos sobre mulheres transgênero estariam fora do espectro de decisões reunidas pelo UNODC por somente terem sido mais recentemente incorporados à lógica repressivo-penal do tráfico após as alterações da Lei 11.106/2005, que modificou o tipo penal de tráfico de mulheres para falar em tráfico de pessoas? ${ }^{4}$

Ao ler os relatórios Globais do UNODC mais recentes, confirmei a impressão de que não há um cuidado na identificação dos casos de mulheres trans, pois a lógica discursiva do

4 Registro existirem notícias divulgadas na rede mundial de computadores sobre condenações de pessoas por tráfico internacional de mulheres trans. A exemplo, a informação disponibilizada no endereço eletrônico do $\begin{array}{llllll}\text { Ministério } & \text { Público } & \text { Federal, em } & 12 & \text { de novembro de } 2014\end{array}$ (http://www.prmg.mpf.mp.br/imprensa/noticias/criminal/sete-acusados-sao-condenados-por-traficointernacional-de-pessoas, acesso em 19 de março de 2016). Esses casos, porém, não estão visíveis dentro do espectro de julgados analisados, ocorridos entre março de 1996 e agosto de 2012. 
tráfico de pessoas é fundamentalmente binária e se divide entre mulheres e homens, sem espaço para performances de gênero que não se encaixam nesses dois grandes modelos. Ficou latente, por tudo isso, a ideia de que é preciso conhecer mais sobre o universo das mulheres trans. Faltam dados sobre a intersecção entre a experiência dessas mulheres e o tráfico de pessoas. Antevi um campo de pesquisa singular, que não poderia caber na presente dissertação, por estar além do alcance dos documentos analisados, mas que merece imersão cuidadosa por parte dos pesquisadores da área.

Retornando ao recorte inicial da pesquisa, com foco no discurso judicial sobre tráfico de mulheres cisgênero, preocupei-me em ler as sentenças e os acórdãos criminais buscando elementos sobre as possíveis vítimas do tráfico internacional para fins de exploração sexual. Ressai das decisões um retrato da mulher traficada internacionalmente? Se sim, que atributos são associados a essa mulher? Ela é considerada uma vítima, dentro da trama discursiva desenvolvida pelos magistrados? Ou é considerada algoz? A quem se imputa a responsabilidade pelo ocorrido? Que tipo de adjetivo é associado à personalidade da mulher traficada?

As inquietudes foram se desdobrando. Queria saber se a voz das pessoas traficadas estava presente nas decisões. Se estivesse presente, qual era o papel jogado pelo espaço de fala daquelas mulheres? Suas narrativas eram essenciais para a condenação ou absolvição por tráfico? A subjetividade da experiência migratória faz parte da tipificação do tráfico no Brasil?

Para tomar forma de pesquisa, minhas inquietações precisaram ser cortadas, limadas, ponderadas e pensadas, de modo a chegar, com isso, à seguinte pergunta central: que tramas discursivas emergem das narrativas da Justiça Brasileira sobre tráfico internacional de mulheres cisgênero?

A hipótese axial que permeou a formulação dessa pergunta era a de que havia uma incongruência entre a objetividade do tipo penal incriminador do tráfico internacional de pessoas, contido no Artigo 231 do Código Penal Brasileiro, e os elementos objetivosubjetivos que emergem do Protocolo de Palermo para caracterização da ofensa, como é o caso da fraude, do engano e, em certa medida, da coação e outras formas de violência que dependem de um juízo de valor para serem identificadas.

Decorrência da hipótese central, preocupei-me em verificar se a vítima do tráfico de pessoas para fins de exploração sexual era ou não invisibilizada dentro do discurso penal 
oficial do Poder Judiciário. Na sequência, procurei elementos que me permitissem correlacionar o aparecimento da fala das mulheres cisgênero supostamente traficadas com a moral social que envolve a questão da sexualidade feminina e do uso mercantil do sexo. Testei, ao final, a hipótese de que o discurso jurídico-penal é utilizado de forma a prejudicar os direitos das mulheres.

O caminho para elucidar essas questões foi trilhado segundo a metodologia de estudo qualitativo com técnica de análise documental. A pesquisa qualitativa tem como foco explorar um tema para entender o significado atribuído pelos indivíduos, grupos ou organizações a um problema social ou humano, como aponta Creswell (2010).

Investigar o papel que a subjetividade ocupa nesses provimentos é também abrir a janela de discussão sobre os regimes de precarização da vida que antecedem o abuso, a coação e o engano de mulheres cisgênero, ou mesmo os meandros da opção livre e esclarecida pelo exercício da prostituição. São questões sociais relacionadas, por exemplo, à desigualdade de classes, à discriminação de gênero e raça, à liberdade laboral e à mercantilização da vida no regime de produção e acumulação capitalista.

O objetivo perseguido em minha pesquisa foi analisar a presença/ausência da vítima nos provimentos jurisdicionais que encerram o exame fático-jurídico dos processos penais sobre tráfico de mulheres cis para fins de exploração sexual, bem como investigar o que essa abertura ou obstrução ao espaço de identificação e subjetividade da vítima diz com relação ao exercício da prostituição.

Trata-se de estudo de caráter indutivo-exploratório, fundado sobre as bases epistemológicas da análise de discurso proposta por Michel Pechêux, Eni Orlandi e Dominique Maingueneau, que se reporta à ideologia veiculada no discurso para perguntar como é que o texto se coloca no intertexto - isto é, na realidade histórica, política, social e das relações de gênero - que o envolve.

Sem pretensão de exaurir o tema, proponho o estudo analítico de dados que possam subsidiar formas de pensamento que modifiquem o regime hegemônico de produção dos saberes sobre tráfico de mulheres para fins de exploração sexual.

A análise das decisões ocorreu em dois níveis. Primeiro foram eleitos códigos essenciais - os termos-pivô, na terminologia de Michel Pechêux - que marcariam pontos de atenção na narrativa das decisões selecionadas. Os códigos foram: mulher, tráfico de pessoas, exploração sexual, prostituição, prostituta, pessoa traficada e vítima. 
Procedida a análise linha a linha, para marcação dos códigos acima, retornei ao material primeiramente para conferir a intensidade do uso do vocábulo vítima em cada um dos casos. Fiz, no mesmo ensejo, a correlação entre o termo vítima e as narrativas das mulheres supostamente ofendidas, o que me permitiria visualizar se havia maior ou menor reconhecimento das mulheres que ali figuravam como pessoas traficadas como vítimas e se sua subjetividade tinha reflexos importantes para a persecução penal do tráfico.

Segui pelo mapeamento dos termos selecionados em função de cinco categorias analíticas: (i) prostituição como exploração sexual; (ii) auxílio à migração para a prostituição como tráfico de pessoas; (iii) exercício da prostituição como degradação moral; (iv) mulher cisgênero migrante como vítima; e (v) migração para prostituição como ingenuidade ou vulnerabilidade.

Destaquei e organizei os trechos discursivos com maior densidade de conteúdo para a análise e, devidamente estruturados os achados da pesquisa, passei a interpretá-los no contexto maior de uma narrativa sobre mulheres, tráfico de pessoas, migração e prostituição.

O estudo conta com três capítulos. No primeiro, intitulado Epistemologias e metodologias por um discurso feminista, procuro demonstrar as bases em que se estrutura a abordagem qualitativa e a análise documental e esclareço as razões pelas quais escolhi como método a análise de discurso. Ainda neste capítulo inaugural, apresento justificativas para a realização de uma abordagem feminista ao longo da pesquisa, que se oponha à lógica hegemônica andro-cis-heteronormativa. Falo um pouco sobre a subalternização dos caracteres sociais associados ao feminino e sobre a necessidade de revisitação dessas bases epistêmicas. Termino com a apresentação de minha perspectiva e lugar de fala neste estudo, com o cuidado de deixar transparente o espaço político da investigação, por reconhecer que o saber científico não é neutro, nem universal, e que o discurso de neutralidade do saber oculta a imposição de verdades universalistas excludentes.

Estereótipos e violências no discurso judicial brasileiro é o segundo capítulo. Inauguro-o com a retomada dos diplomas normativos nacionais e internacionais sobre tráfico internacional de pessoas. Detalho a moldura dentro da qual se desenvolvem as políticas brasileiras de enfrentamento ao tráfico de pessoas e, com base nesse substrato teórico, abro espaço para a apresentação de toda a metodologia empregada no exame da documentação utilizada como corpus de análise. Concluo-o com a apresentação detalhada dos elementos discursivos encontrados e das relações de sentido que eles permitem identificar em torno das relações de gênero, dos estereótipos sobre a mulher migrante e dos valores morais arraigados 
à produção do Judiciário Brasileiro sobre tráfico de mulheres cisgênero para fins de exploração sexual.

O terceiro capítulo se chama Tráfico internacional de mulheres: migração, sexualidade e discurso jurídico-penal. Por uma nova linguagem de proteção do feminino na sociedade pós-colonial. Este é o ponto em que integro os elementos discursivos estudados ao longo do segundo capítulo ao intertexto, que, com isso, passam a fazer sentido, criar sentidos, reproduzir sentidos no mundo em que vivemos.

A expansão do texto para o intertexto começa com a recuperação dos dados, das estatísticas, nacionais e internacionais, sobre qual é a realidade do tráfico de mulheres cisgênero. Neste momento, dedico-me a entender até que ponto conhecemos quem é a mulher brasileira que migra, quais são seus sonhos, seu perfil, de onde e para onde ela parte. Quantas e como são as mulheres traficadas? Qual a sua cor e sua classe social? O que efetivamente ocorre nas suas experiências migratórias?

O segundo ponto enfrentado no terceiro capítulo trata da prostituição e das narrativas que a envolvem dentro e fora do contexto migratório de mulheres. Este tópico se conecta ao terceiro, no qual discorro sobre as limitações inerentes ao discurso penal repressivo das sentenças e dos acórdãos e incito a leitora a refletir sobre novas possibilidades de linguagem para proteção do feminino, em especial, da mulher migrante. Sugiro, ao final, uma aproximação pós-colonial como caminho para a redução das assimetrias de gênero, em abertura para o aprofundamento futuro desta pesquisa. 


\title{
1 EPISTEMOLOGIAS E METODOLOGIAS POR UM DISCURSO FEMINISTA
}

\author{
Perdi meus fantásticos castelos \\ Como névoa distante que se esfuma... \\ Quis vencer, quis lutar, quis defendê-los: \\ Quebrei as minhas lanças uma a uma! \\ Perdi minhas galeras entre os gelos \\ Que se afundaram sobre um mar de bruma... \\ - Tantos escolhos! Quem podia vê-los? - \\ Deitei-me ao mar e não salvei nenhuma! \\ Perdi a minha taça, o meu anel, \\ A minha cota de aço, o meu corcel, \\ Perdi meu elmo de ouro e pedrarias... \\ Sobem-me aos lábios súplicas estranhas... \\ Sobre o meu coração pesam montanhas... \\ Olho assombrada as minhas mãos vazias...
}

(Florbela Espanca in A Mensageira das Violetas)

\subsection{Abordagem qualitativa e análise documental}

Produzi a presente pesquisa com base em abordagem qualitativa, de viés indutivo e caráter empirista, consoante classificação elaborada por Antonio Carlos Gil (1994). Por sua natureza, trata-se de pesquisa básica com objetivo exploratório e amparo documental, consistente em sentenças e acórdãos reunidos na base de dados do Escritório das Nações Unidas contra Drogas e Crime - UNODC acerca da problemática do tráfico de pessoas no Brasil. O país havia enviado dados sobre 78 casos julgados por tráfico de pessoas até dezembro de 2015.

$\mathrm{Na}$ análise qualitativa de dados indutiva, criei meus próprios padrões, categorias e temas, e me comprometi a manter especial atenção aos significados que as autoras do discurso atribuem ao problema questionado. Esse tipo de análise exigiu que me propusesse a despir dos significados que trago pessoalmente, para poder alcançar novos significados emergentes da prática discursiva das investigada (CRESWELL, 2010).

Esse tipo de abordagem chegou a ser menosprezado nos Estados Unidos entre o período da Grande Depressão e o início da década de 1960. O enfoque quantitativo, 
alimentado pela perspectiva positivista de Durkheim, foi fortalecido pela divulgação da tese de doutoramento de Samuel Stouffer, em 1930, na Universidade de Chicago, berço de grandes investigações qualitativas das décadas de 1910 e 1920.

O estudo, intitulado An experimental comparison of statistical and case history methods of atitude research, veiculava a proposição de que, embora questões sociais pudessem ser pesquisadas igualmente por métodos qualitativos e quantitativos, o método estatístico era o mais rápido e de mais fácil aplicação (MINAYO; MINAYO-GÓMEZ, 2003).

A volta do prestígio da pesquisa qualitativa foi impulsionada pela sociologia da década de 1960, em trabalhos sobre etnometodologia, interacionismo simbólico na compreensão de microprocessos sociais e no trabalho de campo com grupos focais e inferência.

Essas pesquisas lançaram luzes sobre a relação entre ciência e poder, desvendando, como elucidam Minayo e Minayo-Gómez (2003), temas como o controle das cidadãs pelo Estado, a problemática racial no campo criminológico e o estudo de instituições totais. Colaboraram, ainda, para discussão profícua acerca da utilidade da ciência como meio de superação dos problemas sociais enfrentados pelo povo em questões públicas que exigem mudanças.

A matéria-prima em pesquisas qualitativas é a fala, a língua escrita ou qualquer das múltiplas formas de comunicação possíveis. O objetivo é aproximar sujeito e objeto, para entender como ações, estruturas e relações significativas emergem de dados como a empatia, os motivos e as intenções das autoras, suas crenças, seus valores e suas aspirações (MINAYO; SANCHES, 1993).

Esse é o perfil da análise metodológica que empreendi, com base na produção escrita dos magistrados responsáveis por aplicar a lei penal em caso de denúncia de tráfíco internacional para fins de exploração sexual de mulheres cisgênero.

De acordo com Creswell (2010), os processos de investigação quantitativos e qualitativos são similares, mas os qualitativos tomam como parâmetro o uso do texto e da imagem, têm etapas particulares de análise e utilizam estratégias distintas de investigação. A opção por uma abordagem qualitativa não exclui, sem embargo, a utilização auxiliar de critérios matemáticos na descrição, representação e interpretação dos dados (MINAYO; SANCHES, 1993).

É com intuito de conciliar técnicas de quantificação e qualificação de dados que pretendi, primeiramente, fixar ligações de regularidade discursiva nos documentos 
selecionados, a partir da categorização de expressões centrais, os termos-pivô ${ }^{5}$. Após, pela mensuração da frequência de códigos específicos, da correlação e do contexto histórico que evidenciam, procurei alcançar, ao final, uma imersão interpretativa não apenas pelos sentidos latentes que as palavras utilizadas veiculam, mas também pela projeção subjetiva e simbólica que emerge do discurso.

Faço a ressalva de que não se trata de pesquisa de métodos mistos, dado que os instrumentos de contagem utilizados são meramente ancilares ao projeto maior de análise discursiva levado a efeito ${ }^{6}$.

O discurso cristalizado pelo Judiciário, como Poder estatal, influencia as estruturas de poder assentes na sociedade, reiterando-as ou modificando-as, o que alimenta especial interesse investigativo no corpus escolhido. É das conexões entre pensamento, linguagem e realidade histórica que emerge a ideologia, metodologicamente retratada, nas palavras de Orlandi, como "mecanismo estruturante do processo de significação" (2007, p. 96).

Observo que os limites da análise documental, na leitura de Creswell (2010), estão associados aos fatos de que (i) as pessoas não são igualmente articuladas; (ii) as informações podem não estar disponíveis ou podem estar protegidas, e, ainda; (iii) a investigação pode requerer informações difíceis de encontrar ou que obriguem a lidar com materiais incompletos, inautênticos ou imprecisos.

Esses entraves, contudo, não se apresentaram de forma contundente ao longo da presente pesquisa. O equilíbrio no nível de instrução dos sujeitos do discurso analisado e a disponibilização pública em meio eletrônico de material jurisdicional autêntico, por organização internacional que trabalha em parceria com o Conselho Nacional de Justiça ${ }^{7}$,

5 Os termos-pivô, ou palavras-chave, são entradas lexicais que podem ser utilizadas como ferramentas para realização da análise de discurso.

6 De acordo com Creswell e Plano Clark, inexiste uma definição única do que seja a pesquisa de métodos mistos. Há, contudo, características essenciais fortemente associadas a ela. Dizem os autores que "nos métodos mistos, o pesquisador: coleta e analisa de modo persuasivo e rigoroso tanto os dados qualitativos quanto os quantitativos (tendo por base as questões de pesquisa); mistura (ou integra ou vincula) as duas formas de dados concomitantemente, combinando-os (ou misturando-os) de modo sequencial, fazendo um construir o outro ou incorporando um no outro; dá prioridade a uma ou a ambas as formas de dados (em termos do que a pesquisa enfatiza); usa esses procedimentos em um único estudo ou em múltiplas fases de um programa de estudo; estrutura esses procedimentos de acordo com visões de mundo filosóficas e lentes teóricas; e combina os procedimentos em projetos de pesquisa específicos que direcionam o plano para a condução do estudo" (CRESWELL; PLANO CARK, 2013, p. 22). Há, na pesquisa de métodos mistos, uma sequência de fases múltiplas de investigação, produção e intercalação de dados de caráter mais amplo, custoso e lento que as quantitativas e qualitativas.

7 Órgão constitucional que direciona o funcionamento administrativo do Poder Judiciário Brasileiro. 
foram grandes facilitadores do processo de pesquisa e auxiliaram na conclusão da investigação subjacente.

O uso desses documentos também foi apropriado e recomendável para a pesquisa por representar o discurso oficial do Poder Judiciário de forma criteriosa, por meio de textos compilados em processo atento pelos magistrados que proferiram as sentenças e os acórdãos estudados.

A análise documental, conceituada por Bardin (1979, p. 45) como "uma operação ou um conjunto de operações visando representar o conteúdo de um documento sob uma forma diferente da original, a fim de facilitar, num estado ulterior, a sua consulta e referenciação", tem como propósitos o armazenamento da informação sob formas variáveis e a facilitação do acesso do observador, mediante ampliação do volume e da pertinência do conteúdo veiculado.

Nesse esteio, o corpo documental estudado foi eleito, de um lado, pela conveniência de que se aprofundasse a leitura dessas sentenças e desses acórdãos, pelo seu potencial informativo acerca da realidade de sentido construída e reproduzida pelo Poder Judiciário no processo penal investigativo do tráfico internacional de mulheres cis em casos de prostituição e exploração sexual. De outro lado, a escolha da amostra é intencional, por subsidiar pesquisas ulteriores que possam, inclusive, vir a contestar ou a observar criticamente a consistência das estatísticas oficiais lançadas pelo UNODC acerca do cenário brasileiro em relação ao tráfico internacional de mulheres cis.

\subsection{A escolha da análise de discurso}

Registrado o fato de que este estudo qualitativo tem por objeto a análise de símbolos e relações que emergem da discursividade das sentenças e dos acórdãos selecionados, cumpre conhecer melhor a análise de discurso enquanto método utilizado para a produção da pesquisa científica que ora se apresenta e os motivos da escolha desse conjunto de ferramentas.

O termo análise do discurso foi identificado num artigo de Harris, em 1952. Ali, o discurso foi aproximado daquilo que também se poderia designar "linguística textual" (CHARAUdEAU; MAINGUENEAU, 2014). Michel Pêcheux, por sua vez, ainda em 1969, conceituava o discurso como contratos linguísticos específicos que veiculam materialmente ideologias (MAINGUENEAU, 1997). Mais recentemente, surgiram linhas com conceitos e objetos variados dentro do que se entende por análise discursiva. Entre os grandes polos 
atuais: (i) o dos que enfocam a interação social; (ii) o dos que se debruçam sobre o estudo dos gêneros de discurso; (iii) o dos que se centram no exame da organização textual ou das marcas de enunciação; e, ainda, (iv) o dos que se inclinam à investigação das condições de produção do discurso, com suas marcas ideológicas (CHARAUDEAU; MAINGUENEAU, 2014).

A eleição da análise de discurso como método não se deu de forma aleatória ou como estratégia vazia de validação da pesquisa no campo científico, como podem afirmar os críticos do uso difundido desse método ${ }^{8}$. Foi escolha consciente tendo em vista o ajuste adequado entre a proposta pesquisada e as possibilidades de investigação científica do material selecionado para análise. Se, de um lado, a noção do que seria análise de discurso é hoje fluida, pela incomensurabilidade do campo de pesquisas que foram levadas a efeito sob esse rótulo, não é menos certo que essa ampliação tem raízes na interdisciplinaridade própria do método. Interdisciplinaridade esta que não se mostra limitadora da produção científica, pelo contrário, impulsiona estudos potencialmente inovadores justamente por não se compartimentalizarem formalmente dentro de um único campo de saber.

O viés de observação dos dados que serão apresentados a seguir deposita suas bases no contributo de Michel Pêcheux, Eni Orlandi e, mais recentemente, Dominique Maingueneau.

Cumpre, primeiramente, assentar um conceito do que seria discurso. Amparo-me na definição de Charaudeau e Maingueneau (2014, p. 168), apontada em seu Dicionário de análise do discurso:

Noção que já estava em uso na filosofia clássica, na qual, ao conhecimento
discursivo, por encadeamento de razões, opunha-se o conhecimento intuitivo. Seu
valor era, então, bastante próximo ao logos grego. Em linguística, essa noção,
proposta por Guillaume, conheceu um impulso fulgurante com o declínio do
estruturalismo o e crescimento das correntes pragmáticas.

A noção atual de discurso está embebida do caldo teórico produzido a partir das décadas de 1960 e 1970 na França, tempo em que houve o crescimento, na Europa, de movimentos sociais, étnicos, de gênero, feministas e ambientalistas, para apreensão dos quais

8 A esse respeito, o posicionamento externado por Baronas (2007) no artigo Efeito de pertencimento à análise de discurso. 
a pesquisa científica marcadamente positivista tinha uma abordagem insuficiente (MINAYO; MINAYO-GÓMES, 2003) ${ }^{9}$.

Naquela época, floresceram três linhas europeias distintas de pensamento teórico dentro do que hoje se concebe como análise do discurso: a de Michel Pêcheux; a sociolinguística de Marcellesi, Gardin e Guespin; e a análise particular de Foucault (NARZETTI, 2010).

As coincidências na orientação teórica perfilhada pelas linhas apontadas estão, entre Pêcheux e os sociolinguistas, na internalização de conceitos marxistas e na teorização do discurso com amparo nas ideias de classes sociais e ideologia.

De outra parte, embora Foucault e Pechêux não concordassem acerca dos reflexos da ideologia no discurso, dada a apresentação, por Foucault, de uma visão particular do fenômeno discursivo, calcada na projeção de uma arqueologia de saberes, compartilhavam tanto a abordagem do sujeito do discurso como resultado de processos históricos de subjetivação quanto a acreditação do método de análise discursiva como instrumento de história dos saberes (NARZETTI, 2010).

Feitas as aproximações e distinções essenciais, tem-se que, no conceito talhado originalmente por Pêcheux, o discurso se coloca em um nível intermediário entre a língua e a fala, figurando como mais que um objeto linguístico: um objeto sócio-histórico. Dizia ele que “todo processo discursivo se inscreve numa relação ideológica de classes" (PÊCHEUX, 1988, p. 92), merecendo exame crítico, pois

A discursividade não é a fala (parole), isto é, maneira individual "concreta" de habilitar a "abstração" da língua; não se trata de um uso, de uma utilização ou da realização de uma função. Muito pelo contrário, a expressão processo discursivo visa explicitamente a recolocar em seu lugar (idealista) a noção de fala (parole) juntamente com o antropologismo psicologista que ela veicula (PÊCHEUX, 1988, p. 91).

A análise discursiva surge como tentativa difusa e transdisciplinar de reflexão sobre escritura, linguística, marxismo e psicanálise (MAINGUENEAU, 1997), conectando-se com o tempo de agitação social pela defesa de novas bandeiras emancipatórias. Ocuparam-se seus primeiros adeptos, num contexto de efervescência social, da construção de um projeto de

9 Essas novas identidades não se viam retratadas "em recortes quantitativos aglomerados, nem no recorte de classe apenas" (MINAYO; MINAYO-GÓMES, 2003, p. 130), porquanto os enfoques totalizantes mitigavam e ocultavam matizes relevantes de expressões subjetivas e de sociabilidades individuais e coletivas. 
abordagem discursiva dos processos político-ideológicos que fosse capaz de melhor interpretar os sentidos da comunicação.

O pressuposto teórico que emerge dessa elaboração hermenêutica é o da ausência de transparência da comunicação, bem como o do reconhecimento dos riscos que a compreensão espontânea do discurso apresenta no contexto da produção de saberes em ciências sociais. Aponta-se a necessidade de apreensão de sentidos que à primeira vista não são evidentes no discurso, por representarem conceitos naturalizados pelo corpo social. A análise discursiva parte, portanto, do estranhamento com relação à mensagem apresentada pela imagem, pelo texto escrito, pela fala, pelos silêncios.

Difere, fundamentalmente, de abordagens eminentemente quantitativas, fruto de formulações mais ortodoxas e positivistas da análise de conteúdo, por não se limitar à garimpagem de códigos e à mensuração de frequências textuais, tratando de identificar o conteúdo apreciado conectado com a realidade maior em que se insere e se reproduz, o intertexto. A análise de discurso, enfim, pode ser entendida como viragem crítica do conteudismo.

A análise de conteúdo, entendida como conjunto de técnicas para análise das comunicações (BARDIN, 1979, p. 42), costuma utilizar procedimentos sistemáticos e objetivos para descrever o conteúdo das mensagens integrantes do corpus pesquisado. Seu princípio-base é desmontar estrutura e elementos do corpus, por meio da elaboração de conceitos operatórios e da definição de planos experimentais, para elucidar suas características e extrair seus significados latentes (LAVILLE e DIONNE, 1999; BARDIN, $1979)^{10}$.

No contraponto, a análise do discurso, na linha teórica de Pêcheux, Orlandi e Maingueneau, não propõe o estabelecimento de limites rígidos entre a linguagem e o social ou psicológico, mas sugere a articulação desses planos interior e exterior. Torna evidente a noção

10 As origens do conjunto de ferramentas da análise de conteúdo remontam à década de 1915, quando $\mathrm{H}$. Laswell analisou sistematicamente a imprensa e a propaganda de seu tempo. Com seu trabalho, Laswell iluminou caminhos de investigação da propaganda e da ciência política por aproximadamente quarenta anos, até o fim da II Guerra Mundial. Contudo, por volta da década de 1940, a análise de conteúdo centrava-se demasiadamente na mensuração de dados por frequência e intensidade, deixando de apresentar resultados interessantes e de responder a perguntas de relevo, o que ocasionou seu parcial abandono nos anos seguintes. É, porém, na década de 1950 que novos estudos são feitos e a análise de conteúdo expande-se para além do espectro descritivo, enveredando também pelos caminhos da inferência e diversificando sua aplicabilidade para as esferas da Etnologia, da História, da Psiquiatria, da Linguística, da Sociologia e da Ciência Política (CAPELLE; MELO; GONÇALVES, 2003). A ampliação do uso do método foi ainda mais sentida após a década de 1960, com a difusão dos computadores, o interesse pelos estudos acerca da comunicação não verbal e a consciência da inviabilidade de precisão dos trabalhos linguísticos (BARDIN, 1979). 
de que o trabalho estatístico de massa por si só não acrescenta o afazer científico e se interessa em responder ao questionamento: como esse texto se coloca no mundo? ${ }^{11}$ Rejeita, nesse ensejo, as pretensões de neutralidade do discurso científico. Nega a existência de um significado real preconstruído a ser meramente transmitido por baixo da mensagem. Ilumina a figura da pesquisadora e os reflexos de seus pressupostos ideológicos e conceituais no encaminhamento da análise. Evidencia, por fim, que a atividade de pesquisa gera interferências na realidade (ROCHA; DEUSDARÁ, 2005).

Elucidam Capelle, Melo e Gonçalves (2003, p. 13) que a análise do discurso segue da enunciação para o discurso, enquanto que a análise de conteúdo, segue, na inversa, do discurso para a enunciação. Como resultado, "a análise do discurso não visa o que o texto quer dizer, como é a posição da análise de conteúdo em face de um texto, mas como ele funciona diante de um determinado contexto social e histórico".

Observa-se que, no desenvolvimento do método que ora se adota, Pêcheux encadeou três etapas de análise do discurso: a da superfície linguística, a passagem ao objeto discursivo e deste para a formação ideológica. Em detalhamento da proposta pêcheuxtiana, Orlandi, por sua vez, recomenda, primeiramente a análise das palavras do texto, com atenção aos adjetivos, substantivos, verbos e advérbios. Sucessivamente, a análise da construção de frases, da construção de uma rede semântica entre o social e a gramática. Por último, considerar a produção social do texto como algo que constitui o seu sentido (CAPELLE; MELO; GONÇALVES, 2003).

Fiorin, de sua parte, acrescenta que a análise do discurso deve atentar às marcas de enunciação deixadas no discurso, a serem identificadas em razão da autora, do espaço e do tempo em que foi produzido (CAPELLE; MELO; GONÇALVES, 2003).

Todos esses elementos foram identificados na análise do corpus dessa pesquisa, a partir da sua relação com os códigos selecionados: mulher, tráfico de pessoas, exploração sexual, prostituição, prostituta, pessoa traficada e vítima.

Esses termos-pivô foram então mapeados em função de cinco categorias analíticas maiores: (i) prostituição como exploração sexual; (ii) auxílio à migração para a prostituição como tráfico de pessoas; (iii) exercício da prostituição como degradação moral; (iv) mulher

\footnotetext{
11 A demarcação teórica dos dois campos investigativos também se dá no sentido do procedimento analítico adotado, por mais que haja autores que classifiquem a análise de discurso como uma entre as diversas técnicas utilizadas pela análise de conteúdo.
} 
cisgênero migrante como vítima; e (v) migração para prostituição como ingenuidade ou vulnerabilidade.

Ainda em termos metodológicos, a corrente mais recente a dialogar com o projeto pêcheuxtiano ${ }^{12}$ coloca os conhecimentos de análise do discurso a "serviço de um projeto militante". Ou seja, busca refletir sobre as formas de poder que se estabelecem por meio do discurso entre os sexos, as raças, as classes sociais (CHARAUDEAU; MAINGUENEAU, 2014, p. 45).

Essa vertente conecta-se com a exploração analítica de textos que pretendi empreender e, desde já, afirmo que o seu potencial grau de subjetivismo não reduz a validade da presente utilização do método de análise discursiva. Pelo contrário, confirma suas próprias premissas, dado que toda interpretação do discurso é permeada pelo olhar de quem interpreta.

\subsection{Bases por uma epistemologia feminista e crítica ao sistema andro-cis- heteronormativo}

Para a presente análise, parto de uma perspectiva de contestação do saber/poder androcêntrico nas ciências sociais, trazida por Sandra Harding (1986) e Donna Haraway (2009), que propuseram uma epistemologia sob a perspectiva feminista. De acordo com as duas autoras, a história da ciência e a construção epistemológica moderna são marcadas, na tradição ocidental, por uma produção que pretende desvincular o discurso científico de perspectivas políticas, históricas, de classe e contextuais. À luz desse paradigma, a pessoa que responde pela pesquisa supostamente apresenta apenas resultados isolados e, por conseguinte, neutros.

Iniciado no racionalismo iluminista e na construção epistemológica do homem ocidental um projeto científico universalizante, objetivo e atemporal, formou-se o paradigma hegemônico de um conhecimento normatizado de bases masculinizada, cisgênero e heterossexual. Apenas quem se enquadrasse na heteronorma teria lugar de fala na construção do conhecimento moderno ocidental ${ }^{13}$.

12 Essa linha tem como expoentes Van Dijk e Wodak, como bem explicam Charaudeau e Maingueneau (2014).

13 "A heteronormatividade expressa as expectativas, as demandas e as obrigações sociais que derivam do pressuposto da heterossexualidade como natural e, portanto, fundamento da sociedade. Na definição de Lauren Berlant e Michael Warner: 'Por heternonormatividade entendemos aquelas instituições, estruturas de compreensão e orientações práticas que não apenas fazem com que a heterossexualidade pareça coerente - ou seja, organizada como sexualidade - mas também que seja privilegiada. Sua coerência é sempre provisional e seu privilégio pode adotar várias formas (que às vezes são contraditórias): passa desapercebida como 
Em seguida, o positivismo científico, forte especialmente nos séculos XVIII e XIX, manteve autorização apenas para o discurso de homens heterossexuais cisgênero, em sua maioria. Dotava-os, numa ponta, de um saber perpetuador da própria esfera de dominação do conhecimento, enquanto, noutra ponta, silenciava as demais falas, subjugadas.

Essas eram as vozes até então dominantes. Simulavam uma neutralidade que dizia apartar o poder da esfera de emanação do conhecimento científico, em nome da objetividade e da validade do discurso nesse campo. O conhecimento e a epistemologia da modernidade pretenderam afirmar um conceito de universalidade que legitimasse sua própria concepção cosmológica, fora da história, do contexto e das condições sociopolíticas e de classe, que seria válido para todo e qualquer tempo e sociedade, com regras que ditassem o certo e o errado.

Surgindo dessa oposição estamos diante da noção binária e simplificadora do que é verdadeiro e falso, da conduta normal e desviante, da condição hegemônica e universal frente à condição contraproducente. Havendo normalização, há, por conseguinte, um desvio da norma que deve ser submetido ao escrutínio do cientista (homem) e devolvido à sua forma padrão.

Encontra-se presente, na condição moderna, o discurso da unidade, do domínio, da conquista hegemônica e da supremacia de uma ideia sobre todas as outras, por ter força legítima. Não surpreendentemente, o paradigma científico da ciência normal foi também constituído pelo discurso proferido por homens cisgênero heterossexuais e que segue omitindo vozes dissonantes. Ou seja, o discurso moderno é, em síntese, também um discurso opressor de quem não performatiza o masculino.

Em poucos espaços da comunidade científica, têm visibilidade grupos subrepresentados, desviantes da condição hegemônica. Mulheres, negras e negros, indígenas, etnias ciganas, homossexuais, bissexuais, pessoas trans e toda a gama dos subalternos étnicosociais. Embora a ciência tenha tido um discurso de imparcialidade e objetividade, a notória exclusão dos grupos sub-representados da construção do saber mostra que a vivência masculina cis-heteronormativa foi predominante no paradigma da ciência normal, naturalizado no preconceito e na desconsideração da capacidade dos grupos subalternos.

linguagem básica sobre aspectos sociais e pessoais; é percebida como um estado natural; também se projeta como um objetivo ideal ou moral.' (2002, p. 230) Em outras palavras, a heternormatividade é mais do que o aperçu de que a heterossexualidade é compulsória. Como um conjunto de prescrições que fundamenta processos sociais de regulação e controle, a heternormatividade marca até mesmo aqueles que não se relacionam com pessoas do sexo oposto" (MISKOLCI, s/d). 
A científicação desses preconceitos legitimava a exclusão, ao comprovar, em bases metodológicas do modelo androcêntrico, a incapacidade das mulheres, das pessoas negras e das pessoas homossexuais, dentre outros, para "fazer ciência".

Sob a ótica do distanciamento sujeito-objeto e da construção de um projeto científico totalizante e universalizante, os critérios científicos refletiram, ao longo do tempo, a voz daquelas pessoas que produziam o conhecimento, escudando-se, pela aura de objetividade e pretenso afastamento, da responsabilidade sobre a pesquisa.

Marcado pela construção hegemônica de poder, o paradigma moderno não se fundou apenas nas estruturas econômicas de dominação, mas também nas estruturas sociais e normativas. Ao perpetuar a exclusão dos grupos sub-representados, pôde-se oprimir e silenciar, monitorar e punir por sua própria existência aquela gente que se desviava do padrão branco, cisgênero, masculino, heterossexual e rico. Assim, o sistema-mundo do Ocidente se sustentou criando bases subalternas em questões de raça, gênero, sexualidade e exclusão financeira dos meios de produção.

Importante também considerarmos o momento histórico entre a segunda metade do século XIX e o século XX. O fim dos sistemas escravagistas, a eclosão dos movimentos feministas e os primeiros estudos sobre a sexualidade começaram a romper padrões. Eventos convulsionaram o mundo, o choque das Grandes Guerras mostrou uma face terrível do conhecimento científico instituído. O nazismo, que pode ser considerado o ápice de um projeto de mundo ariano andro-cis-heteronormativo, criou um consenso social de que haveria que estabelecer limites para a atrocidade e a opressão.

Portanto, foi no final do século XIX e, principalmente, começo do século XX, que os estudos sobre sexualidade e gênero tiveram, ao mesmo tempo, o papel de reforço e de contestação dessa virada epistemológica. Primeiro, passaram a influir nas identidades dominantes, pois foi a partir do estudo da pessoa homossexual que surgiu a percepção da identidade do heterossexual, este o padrão dominante e normativo, aquele o desviante e que precisaria ser devolvido à normalidade. Ainda dentro do padrão binário de pensamento, com estudos do gênero feminino surgiu a noção de identidade de gênero masculina, esta também o padrão dominante (MISKOLCI, s/d).

A naturalizada e omitida dominação histórica tornou-se mais evidente. Ocorre que, apenas na condição de subalternos, os grupos oprimidos e dominados foram nomeados, reconhecidos e determinados num primeiro momento. Somente quando a dominação, antes 
tida como natural, passou a ser mais claramente visualizada, houve espaço para o primeiro grito dos excluídos.

Surgem, nesta senda, as primeiras teorias feministas, com as críticas de Simone de Beauvoir ao androcentrismo na filosofia e na ciência, como também os embriões dos Estudos Culturais e pós-coloniais. A estrutura paradigmática da ciência foi rompida, ocasionando uma nova revolução científica, como diria Thomas Khun (1975). Assim despontaram os estudos feministas e a pergunta, realizada por Sandra Harding (1986), sobre se haveria uma epistemologia ou metodologia feminista da ciência.

A crítica feminista ao modelo hegemônico androcêntrico da produção científica e a exclusão massiva das mulheres da comunidade atacaram também a noção de que o conhecimento científico é atemporal, universal e objetivo. O conhecimento científico emerge de um lugar de fala e isso deve ser levado em consideração na produção do saber. É, portanto, histórico, contextualizado e assumidamente experiencial, sendo que essa dimensão deve ser considerada e incluída na sua própria construção.

Conta-se, hoje, com uma epistemologia feminista, para a qual pesquisadoras que se compreendem como mulheres podem contribuir substancialmente, em razão de suas vivências nessa identidade.

Haraway (1991) propôs uma desconstrução dos modelos metanarrativos da ciência, cujo protagonista, como dito, era o homem branco, cisgênero, heterossexual, rico e ocidental. Expoente do pós-modernismo feminista, propõe um novo estudo da condição de gênero, em que o sujeito histórico mulher não é um tipo essencial, mas uma construção de arquétipos e vínculos sociais de poder e estrutura. No esteio dos seus ensinamentos, o projeto dessa pesquisa partiu para a análise da realidade discursiva do Poder Judiciário brasileiro usando como base a discussão do gênero, numa tentativa de desconstrução do grande relato moderno e essencialista do padrão normativo e moral de comportamento exigido das mulheres.

\subsection{Política de conhecimento: minha perspectiva e lugar de fala como pesquisadora e o espaço político da investigação}

Produzir conhecimento é influir nas estruturas de poder de uma sociedade. Os reflexos da elaboração de um discurso acadêmico podem ser sentidos em micro ou macroestruturas. Porém, independentemente da magnitude de seu impacto, necessariamente interagem com a rede de influências que informam a vida em sociedade. 
O discurso científico, com os seus propósitos essenciais de produção de "verdades", ao transitar pelos diversos campos de intelecção em que é lançado e constituir-se em poder, atrai para quem realiza a pesquisa responsabilidades que vão desde o compromisso com os métodos de validação que regem seu trabalho até a preocupação com os reflexos do que propõe além dos muros da Universidade.

Não é sem razão que Foucault, em análise do percurso analítico do trabalho dos intelectuais de esquerda, observava o deslocamento dos escritos deles ao longo do tempo. Enquanto os primeiros herdeiros de Marx, em defesa de uma consciência comum e pretensamente universal, comprometiam-se com a defesa de ideias que reproduzissem um senso de justiça próprio - numa espécie de retomada do platonismo grego —, seus sucessores deslocaram o enfoque para identificar na fecundidade de práticas sociais e institucionais localizadas campo suficiente para pesquisas. Pretendiam, a partir daquele ponto de investigação, revisitar a realidade em perspectiva contra-hegemônica, com identificação de ligações transversais de saber e poder (FOUCAULT, 2012).

E foi assim que Foucault passou à problematização do papel do intelectual e sugeriu que a dificuldade por ele enfrentada deveria ser encontrar meios de construir uma nova política de verdade. Alterar os regimes político, econômico e institucional de produção do saber, mais que tentar ilustrar as pessoas.

A mim, pesquisadora, impõe-se o desafio de desvincular o poder da verdade das formas hegemônicas de funcionamento da sociedade. Para esse fim é que se colocam pequenas e sucessivas dificuldades que vão desde a identificação de um campo relevante para a pesquisa, com um certo recorte espacial e temporal, passam pelas complexas escolhas das perguntas a serem feitas e alcançam os métodos de análise empreendidos.

Ao analisar o discurso, também produzo discurso e interfiro na realidade discursiva maior que me envolve. Inexiste discurso neutro. Discurso, ideologia e história estão fundamentalmente imbricados na produção de saberes científicos.

Parto, assim, do reconhecimento prévio da artificialidade de tentar cindir o mundo da pesquisa e o mundo da ação. Os métodos de validação são a janela de diálogo acadêmico e os limites do discurso científico. Para além da observação constante e rígida do método de análise, fica aberto o campo de disputa discursiva entre saberes, onde há muito espaço a ser ocupado pelos estudos de gênero, razão que se conecta com o recorte do presente estudo no 
processo discursivo que envolve sentenças e acórdãos judiciais sobre tráfico de mulheres cisgênero em casos de prostituição e de exploração sexual.

A adoção de uma postura supostamente neutra em face das relações de gênero seria a renúncia à tentativa de mudança, a aceitação tácita das distorções que o discurso penal do Judiciário é capaz de promover nessa seara. O que a transparência exige, porém, é que informe, desde o início da apresentação de meus achados, a política de conhecimento a que me vinculo, os pressupostos que adoto e as concepções em que me firmo, pessoalmente, para selecionar o corpus de análise discursiva e nele mergulhar.

Assim é que a eleição de códigos em função das categorias "prostituição como exploração sexual", “auxílio à migração para prostituição como tráfico de pessoas", "exercício da prostituição como degradação moral”, "mulher cisgênero migrante como vítima" e "migração para prostituição como ingenuidade ou vulnerabilidade" está inextricavelmente associada ao reconhecimento de minha posição como feminista em busca de respostas sobre o que efetivamente vem a configurar o problema do tráfico internacional de pessoas e quais são as narrativas à sua volta.

O engajamento na luta feminista em defesa da autonomia das mulheres favoreceu o recorte do tema da pesquisa. As metodologias de produção do conhecimento científico sob a perspectiva de gênero, quando rigorosamente observadas, possibilitam o diálogo acadêmico sobre novos temas e viabilizam a exploração de temas antigos, porém ainda atuais, em busca de narrativas que iluminem pontos invisibilizados pelo discurso corrente e dominante. Pesquisar na área de interesse feminino é se lançar à produção de saberes que interferirão nas relações de poder já estabelecidas, em favor da igualdade de gênero. Abre-se, nesse intento, a possibilidade de uma discursividade menos androcêntrica e da oxigenação de pautas feministas que não sejam conservadoras.

Entre as possibilidades de articulação com os conceitos de relações de gênero e patriarcado, foi escolhido apenas o primeiro para a pesquisa apresentada. Isso em razão da flexibilidade que o conceito de relações de gênero permite alcançar quando se pensa na estrutura dos arranjos sociais e na fluidez do exercício de poder, que não se compartimentaliza dentro da bipolaridade tradicional da sexuação entre o feminino e o masculino.

Não que a alusão às mulheres ou ao feminino deixe de ser relevante para a pesquisa. Pelo contrário, para facilitação da metodologia da pesquisa, o corpus documental foi formado exclusivamente em função da mulher cisgênero que migra ao exterior. Essa alusão ao 
feminino e ao "ser mulher", enquanto construtos socioculturais absorvidos pela pessoa e performatizados por ela à sua própria maneira, é permanente ao longo do texto.

Sem embargo, a opção pela articulação com o conceito de relações de gênero possibilitará, mais adiante, em estudos futuros, refletir, sobre os mesmos pilares teóricos, acerca do tráfico de pessoas também com relação a transgênero, homens, crianças e adolescentes. Uma realidade holística merece ser tratada com conceitos flexíveis, que tenham aptidão para moldar-se à complexidade da vida e não pretendam essencializá-la.

Quando se fala em prostituição e exploração sexual, a proposta de investigação das relações de gênero subjacentes parece apropriada para questionamento dos discursos dominantes, por dois motivos cruciais.

O primeiro, de que o próprio uso da categoria patriarcado, ainda que sob o marco do "patriarcado contemporâneo", reforça, mesmo no plano discursivo latente, a ideia de que o feminino se constrói a partir do masculino e de que há uma rígida estrutura por trás dos papeis exercidos por mulheres e homens socialmente. Esse pressuposto implícito gera inconsistências quando se pensa nos grupos que não performam suas identidades dentro desse binarismo, como as e os transgênero.

O segundo, de que o abandono do patriarcado como lente de apreensão das relações sociais de gênero permite, tal como nos ensina Machado (2000), ver o sistema de relações sociais entre os gêneros em suas próprias contradições e notar "a fragilidade desse patriarcado que se quer apenas entre homens, mas que tem sido levado a afirmar cada vez mais os direitos políticos, civis e familiares das mulheres”. Desse modo, empreendo a tentativa de captar as dificuldades inerentes à conceituação internacional do tráfico de pessoas para fins de exploração sexual sob o prisma dos "embates entre feministas e não feministas, entre posições de expansão dos direitos individuais e posições conservadoras e neoconservadoras" (MACHADO, 2000, p. 12).

O reconhecimento cultural não está dissociado do funcionamento da economia política. A transformação dos modos de regulação social da sexualidade e da formação de identidades se reflete na divisão do trabalho, nos fluxos de capital, em opressões materiais diversas, na própria reafirmação ou reformulação da família tradicional heterossexual e chefiada pelo sexo masculino (BUTLER, 1996).

O fluxo migratório internacional de mulheres cis brasileiras para exercício da prostituição e também de outras atividades laborais tem impactos não apenas com relação à 
moral cristã conservadora que prevalece no Ocidente. Impacta a produção e a circulação de riquezas, a remessa externa de valores para sustento das famílias e redes de apoio na origem. Tem reflexos econômicos relevantes e de empoderamento individual e social, portanto. Por esse mesmo viés, a própria leitura da prostituição voluntária como trabalho ou como não trabalho aponta para possibilidades distintas de articulação política ao seu redor, seja para legalizá-la, criminalizá-la, aboli-la ou regulamentá-la.

O laço entre a identificação cultural da mulher que migra e as engrenagens econômicas e políticas que o seu deslocamento agita não deve ser menosprezado quando se fala em tráfico de pessoas. É ponto nevrálgico para a compreensão mais profunda das políticas, das identidades e das relações que se formam no campo de estudo.

Do mesmo modo, o aprofundamento sobre os pressupostos que levam à associação da legislação penal entre migração para prostituição e tráfico de pessoas na modalidade de exploração sexual traz reflexões interessantes sobre o impacto negativo de políticas moralizantes e de veio abolicionista da prostituição na construção do projeto de vida de mulheres cis brasileiras que decidem migrar, independentemente da atividade que pretendam ou venham a exercer no exterior.

Cidadania, identidade, reconhecimento, economia, permeabilidade de fronteiras: são campos que se imbricam na construção sócio-histórica, normativa e política da figura do tráfico de pessoas para fins de exploração sexual. E como o fenômeno jurídico não é um sistema fechado de normas autorreferentes, pode-se entender que a demarcação do que lemos por tráfico de pessoas somente poderá advir do direito positivado na medida em que o conceito legal esteja em consonância com o que o discurso e as práticas contra-hegemônicas por reconhecimento de direitos humanos consideram legítimo.

A imersão pelas contradições do direito legislado internamente, bem como das normas de proteção dos direitos humanos pactuadas internacionalmente — de seu conteúdo e forma de aplicação - integra a busca da legitimidade dos controles e das políticas de enfrentamento ao tráfico de mulheres cisgênero. Nesse esteio, o objetivo da pesquisadora foi utilizar a investigação sociojurídica como instrumento de emancipação social, anseio que repousou sobre as bases da proposta filosófica de Roberto Lyra Filho (1982), para quem o direito se enuncia como modelo de "legítima organização social da liberdade" 14 .

${ }^{14}$ Nas palavras de Lyra Filho: “(...) o direito é, antes de tudo, liberdade militante, a afirmar-se evolutivamente, nos padrões conscientizados de justiça histórica, dentro da convivência social de indivíduos, grupos, classes e 
A construção paulatina do plexo de direitos humanos das mulheres perpassa, no particular, a investigação de como o Poder Judiciário, como instância oficial do sistema jurídico, dita, no âmbito da persecução penal, o que configura tráfico de mulheres cisgênero para exploração sexual e o que não. Mais: como é que esse ramo de Poder veicula, pela reprodução da lei penal, um discurso moralizante das relações sociais.

O discurso Judicial, transversa e ocultamente, é capaz de reafirmar assimetrias e desigualdades, atuando em sentido oposto à proteção da liberdade e da realização maior dos direitos humanos. Pode, ainda, pelo viés da ingenuidade de sua reprodução, conduzir a uma sistemática de julgamento que, em termos de estatística penal, desencadeie a formulação de políticas públicas enviesadas ou estéreis, incompatíveis com o cenário ainda não devidamente caracterizado do tráfico internacional de mulheres brasileiras cis para exploração sexual.

Por conta desses riscos inerentes à produção e reprodução automática e naturalizada do discurso judicial, algumas inquietudes acompanharam a pesquisa. Afinal, é possível vislumbrar a subjetividade da mulher "vítima" dentro da sentença penal? Se não, como é que o discurso penal punitivo da exploração sexual se coloca no mundo? Ele veicula potencial transformador das estruturas assentes de poder e discriminação da mulher? Tem um viés conservador? Esses questionamentos foram o filtro para a aproximação inicial ao acervo documental selecionado e permaneceram latentes ao longo de todo o processo metodológico de exploração e análise levado a efeito.

Como ensina Sousa Santos (2013), é comum partir da hegemonia dos direitos como linguagem universal de dignidade humana. O problema é que, embora haja um aparente consenso acerca dessa noção de dignidade, a maioria da população mundial figura como simples objeto de discursos de direitos humanos. Não como sujeito desses direitos.

Dentro dessa "gramática despolitizada de transformação social" (SOUSA SANTOS, 2013, p. 48), utilizada pelas instituições oficiais do Estado, tem-se uma janela para a perigosa inversão ideológica dos valores e para o risco de utilização do discurso protetivo como arma política utilizada em diferentes contextos, até mesmo contraditórios, por quem concentra o poder econômico e político no cenário capitalista globalizado.

A investigação de possibilidades discursivas e práticas de veio emancipador pode orientar a reelaboração de pautas políticas em defesa dos direitos das mulheres e interferir na

povos - e isso quer dizer que o direito é então, em substância, processo e modelo de liberdade conscientizada ou conscientização libertadora, na e para a práxis transformativa do mundo" (LYRA FILHO, s/d, p. 500). 
discursividade hegemônica, subvertendo-a. Além disso, a abordagem em questão tem o potencial de subsidiar reflexões futuras acerca da própria dificuldade de manutenção da formação discursiva calcada na proteção dos direitos humanos por reafirmação dos controles penais e migratórios, como se indicará mais adiante. 


\section{ESTEREÓTIPOS E VIOLÊNCIAS NO DISCURSO JUDICIAL BRASILEIRO}

O sexo e a sexualidade não são degradantes nem desumanizantes por si mesmos nem sequer quando há dinheiro no meio; nem sequer se aceitássemos que o sexo comercial ou não - implica a coisificação do outro para o consumo ou a satisfação pessoal. Sua decodificação depende sempre do marco cultural e social em que se inscrevem e na imbricação complexa desse marco com as diversas e diversificadas formas de experimentar subjetivamente o sexo. Pensar a sexualidade ligada ao domínio masculino e à submissão feminina, ao avassalamento e à coisificação dos corpos femininos apenas pelo desejo masculino - não como possível narrativa erótica construtora de masculinidades, mas como algo dado e definidor - e pensá-la ligada à identidade e subjetividade como base da dignidade são conceituações problemáticas, porque não só podem carregar visões reducionistas das relações de gênero, mas podem, além disso, terminar avalizando posturas cristãs conservadoras, as quais, sabemos, nunca beneficiam as mulheres (DAICH, 2012, p. 80. Tradução livre).

\subsection{O tráfico de pessoas sob o prisma dos diplomas normativos nacionais e internacionais}

A proposta de investigar os processos discursivos que envolvem o ato de julgar, em primeira ou segunda instância, processos judiciais sobre tráfico internacional de mulheres cis faz referência a tempo, cultura, história e lugar. O discurso judicial oficial brasileiro é produto de relações de sentido maiores.

Caroline Ausserer (2011) reflete sobre o discurso do tráfico de pessoas como problema de migração. Considera que os esforços em homenagem à proteção da humanidade e da dignidade das vítimas do tráfico são, antes, mecanismos de controle para prevenir e responder à migração não documentada. Propõe um deslocamento contra-hegemônico na lógica argumentativa de proteção da vítima, observando os pontos em que o discurso de proteção dos direitos das pessoas traficadas apresenta contradições e incongruências com relação aos anseios dessas pessoas. Salienta, a propósito, que o processo de construção da categoria migrante não é natural, mas social.

O recrudescimento das políticas antitráfico demonstra, segundo a autora, que a vítima cujos interesses se pretende resguardar é o Estado, não a pessoa. A ameaça ao pilar essencial da soberania emerge do rompimento indevido das fronteiras estatais por quem não está autorizado a ingressar no território. As pessoas não documentadas desobedecem os parâmetros seletivos de permeabilidade das fronteiras. Sua identidade é, em virtude disso, trabalhada como risco à soberania nacional e ao bem estar de cidadãs locais. 
Migrantes não documentadas agridem os códigos de cidadania e pertencimento estabelecidos no território para onde vão. Decerto que, por vezes, sua presença traz benefícios objetivos para as pessoas locais. Principalmente quando a sua marginalização se entrelaça com as necessidades de prestação de serviços e execução de atividades pouco valorizadas. Labor em áreas de parco reconhecimento social, desgastante, prejudicial à saúde. Dificilmente a pessoa indocumentada questionará distorções remuneratórias ou de regime de trabalho injustas. Nesse ponto, a sua presença invisível convém ao regime capitalista (Mendonça, L.; 2014). O ponto mais perverso, entretanto, está em que, caso não mais convenha ao Estado cerrar os olhos para a sua presença, a pessoa indocumentada poderá ser descartada.

Os instrumentos de transformação de migrantes em refugo do mundo globalizado, por excelência, são a deportação e expulsão. E ainda que as políticas de enfrentamento ao tráfico de pessoas se digam embebidas do veio protecionista da humanidade universal, é perspicaz a anotação de Ausserer (2011, p.118) de que “o Protocolo de Tráfico dedica mais da metade do próprio texto à especificação do fortalecimento de regimes de fronteira, e visa à proteção das pessoas traficadas, sobretudo, em termos de "repatriação"”.

Retomemos, rapidamente, o veio dos instrumentos de enfrentamento ao tráfico de pessoas no espaço das negociações internacionais. A primeira referência de que se tem notícia sobre tráfico de pessoas, no contexto da ascensão capitalista e do imperialismo, foi o Tratado de Paris, firmado entre Inglaterra e França no ano de 1814, para suprimir o comércio de pessoas negras escravizadas para fim de exploração laboral (LIMA; SEABRA, 2011). Essa foi a base normativa sobre a qual se erigiu, pouco mais de um século depois, a Convenção sobre a Escravatura assinada em Genebra (1926), ainda sob os auspícios da Sociedade das Nações.

Após a sucessão do projeto da Sociedade das Nações pelo da Organização das Nações Unidas, no ano de 1946, os termos da Convenção de Genebra de 1926 foram confirmados, quando já vigia a Convenção 29 da Organização Internacional do Trabalho em relação ao trabalho forçado ou obrigatório (1930).

O parâmetro para configuração do tráfico de pessoas escravizadas seriam atos de captura, aquisição ou cessão de indivíduo com o propósito de escravizá-lo, bem assim os de cessão, por venda ou troca e todo ato de comércio ou transporte de gente submetida à 
escravidão. Em $1956^{15}$, foram incluídas práticas análogas à escravidão, como a servidão, a prisão por dívida, o casamento forçado com fim lucrativo, a entrega - ainda que a título não oneroso - de mulher casada por cessão do marido ou ante o seu falecimento, ou de criança ou adolescente para exploração.

No texto da Convenção de 1926, o comprometimento com a repressão do tráfico de pessoas escravizadas alcançava a tomada de medidas impeditivas do embarque, desembarque e transporte por via aquática. No processo de apropriação do diploma normativo pela Organização das Nações Unidas, houve cuidado em acrescentar o dever de proteção das fronteiras aéreas e terrestres dos pactuantes. A permeabilidade seletiva dos marcos territoriais do Estado, na configuração herdada do absolutismo europeu, estava consagrada textualmente como marco da política migratória dos países do centro ${ }^{16}$ quase um século atrás.

A questão do deslocamento de mulheres entre fronteiras também esteve em pauta no alvorecer do século XX. Sob o enfoque da prevenção da exploração sexual e da violência contra a mulher, a movimentação internacional foi inicialmente sentida com o Acordo para a Repressão do Tráfico de Mulheres Brancas, no ano de 1904, em Paris, convolado, em 1910, em Convenção Internacional. O recorte era basicamente para responder ao cenário de intensificação da migração feminina na Europa, em especial das mulheres provenientes do Leste Europeu, o que também se conecta com a restrição do escopo da proposta em função da cor. Contudo, prevalecia, nessa época, o discurso da autonomia da vontade, entendendo-se que as casadas ou solteiras maiores somente seriam consideradas vítimas de tráfico em caso de fraude ou constrangimento (CASTILHO, 2008).

O ano de 1921 marcou a Convenção Internacional para Supressão do Tráfico de Mulheres e Crianças ${ }^{17}$, independentemente de raça e cor. O de $1933^{18}$, a Convenção para a Supressão do Tráfico de Mulheres Adultas, quando o consentimento passou a ser irrelevante para a mulher adulta e a casada, cristalizando o veio abolicionista na abordagem da prostituição. Em 1947, adveio, por fim, o Protocolo de Emenda à Convenção Internacional para a Supressão do Tráfico de Mulheres e Crianças e à Convenção para Supressão do Tráfico de Mulheres Maiores.

\footnotetext{
15 Convenção Suplementar sobre a Abolição da Escravatura, do Tráfico de Escravos e das Instituições e Práticas Análogas à Escravatura, de 1956.

${ }^{16}$ Faço uso dos termos centro e periferia para referir-me, de um lado, aos países europeus e àqueles que, como os Estados Unidos, integraram-se ao sistema global como colonizadores da subjetividade, da autoridade, da economia e da epistemologia da América Latina, da África e da Ásia.

17 Promulgada, no Brasil, pelo Decreto no. 23.812, de 30 de janeiro de 1934.

18 Promulgada, no Brasil, pelo Decreto n-. 2.954, de 10 de agosto de 1938.
} 
Embora o primeiro dos quatro instrumentos (1910) não pretendesse a extinção da prostituição, autorizando o seu exercício por opção de livre vontade de mulheres casadas ou maiores, tanto nele quanto nos três que o seguiram a prostituição figurava como atentado à moral e aos bons costumes (CASTILHO, 2008). Mais: embora o último tratasse também de crianças, todos tinham como centro de articulação política o problema da mulher migrante.

Posteriormente consolidados os diplomas de 1910, 1921, 1933 e 1947 na forma da Convenção e do Protocolo Final para a Repressão do Tráfico de Pessoas e do Lenocínio de Lake Success, em $1949^{19}$, houve alteração na diretriz inicial para que se passasse a identificar como vítima do tráfico qualquer pessoa, independentemente do sexo e da idade. Gravava-se, na história do discurso do tráfico de pessoas, um novo marco regulatório, mais amplo. No entanto, a potencial viragem por novos caminhos de reflexão sobre outros temas que não a prostituição e a exploração sexual deixou de ocorrer.

Ficou latente o propósito específico de utilizar a Convenção para eliminar a prostituição, por seu mal intrínseco, e consequentemente o tráfico que a acompanhava (PISCITELLI; VASCONCELOS, 2008). O aliciamento para a prostituição, ainda que consentido, bem como as atividades de dirigir, financiar ou contribuir para o financiamento de casa de prostituição, também deveriam ser reprimidos. Os Estados-Partes comprometiam-se, na forma do Artigo 6o da Convenção de 1949, “a tomar todas as medidas necessárias para revogar ou abolir toda lei, regulamento ou prática administrativa segundo os quais as pessoas que se dedicam ou se presume dedicarem-se à prostituição devem inscrever-se em registros especiais, possuir papeis especiais ou ficarem sujeitas a condições excepcionais de vigilância ou de notificação". O tráfico de pessoas passou a figurar, explicitamente, como bandeira moralizante da migração para fins sexuais. Uma bandeira não mais restrita às mulheres, mas ainda fortemente direcionada a elas.

Foram sucessivas as tentativas de aprimoramento daquele marco regulatório de 1949. Surgiram a Convenção sobre a Eliminação de todas Formas de Discriminação contra a Mulher (CEDAW), de 1979; a Convenção Interamericana sobre Tráfico Internacional de Menores (1994) ${ }^{20}$; e a previsão, no Estatuto de Roma (1998), da prostituição forçada e da escravidão sexual como crimes contra a humanidade.

Mais recentemente, surgiu o Protocolo Adicional à Convenção das Nações Unidas contra o Crime Organizado Transnacional (NAÇÕES UNIDAS, 2003), mais conhecido como

19 Promulgada, pelo Brasil, na forma do Decreto n-. 46.981, de 8 de outubro de 1959.

20 Promulgada, no Brasil, pelo Decreto n-. 2.740, de 20 de agosto de 1998. 
Protocolo de Palermo, com a proposta de abranger o tráfico de todos os seres humanos, independentemente de gênero, raça, cor ou idade. Afirma destinar-se a combater a exploração da pessoa humana qualquer que seja o seu gênero e inaugura, nas palavras de Castilho (2008, p. 11), uma nova "fase do controle jurídico internacional em matéria de tráfico e de prostituição".

O tráfico de pessoas é associado hoje à mobilidade social em função do desemprego, de perseguições e conflitos políticos, crises familiares e sociais, guerras e outros. Não mais se reduz à exploração da prostituição. Diz-se caracterizado o problema, sob os auspícios do Protocolo de Palermo (NAÇÕES UNIDAS, 2003), quando se configure uma ação como o recrutamento, o transporte, a transferência, o alojamento ou o acolhimento de pessoas, perpetrada por meio de ameaça, fraude, engano, uso da força ou outras formas de coação como rapto, abuso de autoridade, aproveitamento de situação de vulnerabilidade, entrega ou aceitação de pagamentos ou benefícios - para obter o consentimento de uma pessoa com a finalidade de explorá-la.

Há, portanto, uma ação, um meio e uma finalidade predefinidos quando se fala em tráfico de seres humanos, sendo que a exploração é caracterizada internacionalmente por mínimos ${ }^{21}$. Os mínimos são: a "exploração da prostituição" de outra pessoa ou outras formas de exploração sexual, trabalho ou serviços forçados, escravatura ou práticas similares à escravatura, servidão ou remoção de órgãos. A situação de vulnerabilidade, por sua vez, é conceito em aberto, cuja densidade é traduzida com base na interpretação dos sistemas nacionais de Justiça Criminal, e pode gerar abordagens distintas e, mesmo, contraditórias, de quem seria vítima e quem não 22 .

A tensão acerca do que se deveria considerar exploração no contexto do tráfíco marcou os trabalhos preparatórios da Convenção contra o Crime Organizado Transnacional. Esse ponto era crucial para que se pudesse traçar o escopo e o alcance de aplicação do Protocolo de Palermo (NAÇÕES UNIDAS, 2003). As notas interpretativas para os documentos oficiais da negociação terminaram por assentar três parâmetros básicos (NAÇÕES UNIDAS, 2000).

\footnotetext{
21 Apenas com relação a crianças e adolescentes o meio é desconsiderado.

22 Os trabalhos preparatórios da negociação do Protocolo de Palermo faziam alusão ao abuso de uma situação de vulnerabilidade como "toda situação em que a pessoa interessada não tem mais opção verdadeira nem aceitável que submeter-se", parâmetro bastante elástico e de aplicação discricionária (NAÇÕES UNIDAS, 2000, p. 12. Tradução livre).
} 
Os dois primeiros eram de que a extração de órgãos de crianças com o consentimento dos responsáveis ou por razões médicas ou terapêuticas legítimas não seria considerada exploração e de que a adoção ilegal poderia vir a configurar exploração quando equivalesse a práticas análogas à escravidão (NAÇÕES UNIDAS, 2000). O terceiro, concernente ao tráfico de pessoas adultas, centrou-se na prostituição e na exploração sexual para, antes, frisar a inexistência de um parâmetro uniforme de abordagem. Dizia-se:

64. Nos trabalhos preparatórios se indicará que o Protocolo aborda a exploração da prostituição alheia e outras formas de exploração sexual unicamente no contexto do tráfico de pessoas. Os termos "exploração da prostituição alheia" ou "outras formas de exploração sexual" não se definem no Protocolo, que em consequência não prejulga a maneira em que os Estados-Partes abordem a prostituição em seu direito interno (NAÇÕES UNIDAS, 2000, p. 13. Tradução livre).

E a indefinição permaneceu na redação final do documento, que não pautou o que seria "exploração", limitando-se a demarcar parâmetros não exaustivos do que deveria ser abordado pelos Estados-Partes como tráfico de pessoas e a rejeitar o lucro como elemento essencial. As maiores dificuldades narradas pelo UNODC, nesse particular, consistiam (i) na preocupação em não reduzir indevidamente a proposta do Protocolo, (ii) nas divergências de opinião sobre quando e como as formas de exploração deveriam ser definidas, bem assim (iii) na recusa de certas formas de exploração propostas, como o trabalho doméstico, o turismo sexual e a maternidade forçada (NAÇÕES UNIDAS, 2015).

Aproximadamente quinze anos depois da criação do Protocolo de Palermo (NAÇÕES UNIDAS, 2003) esse posicionamento de não uniformização de entendimentos sobre tráfico, prostituição e exploração sexual persiste. Ao final do ano de 2014, representantes de doze países reuniram-se em Viena para tentar aperfeiçoar os parâmetros interpretativos da exploração. Entre as marcas em que avançaram, esteve o reconhecimento de que as definições internacionais de escravidão e trabalho forçado são parâmetros relativamente seguros a serem importados para classificar a ocorrência de tráfico de pessoas na prática. Por outro lado, o encontro redundou no simples reconhecimento de que a servidão, as práticas similares à escravidão e a "exploração da prostituição" não contam com um entendimento jurídico geral sobre seus significados, muito embora sejam relevantes para a interpretação do conteúdo e da finalidade do Protocolo de Palermo.

No que tange à prostituição, portanto, o consenso atual se exaure no ponto em que se reconhece que a atividade por si só não configura tráfico de pessoas, exigindo-se que um terceiro colha benefício da prostituição de outrem. A exploração, por esse viés, poderia se 
caracterizar na injustiça do benefício auferido, a ser medida na forma da legislação interna de cada país. Chaves interpretativas como o grau de severidade da exploração e o contexto cultural e nacional detêm, também nesse particular, relevante espaço de atuação, o que não afasta questionamentos sobre o que deve ou não ser considerado injusto ${ }^{23}$.

Pairam dúvidas acerca do grau de intencionalidade da abstenção dos Estados-Partes quanto ao equacionamento das disputas discursivas acerca do que se deve ou não considerar exploração da prostituição alheia e outras formas de exploração sexual. Há quem cogite que a manutenção dessa postura denota aparente neutralidade do diploma no que se refere à prostituição, como anota Piscitelli (2008). Essa mesma abstenção, porém, desemboca nos acirrados debates sobre as possibilidades de interpretação do que vem a ser o consentimento válido. Igualmente, reflete incertezas sobre o que seria o abuso de situação de vulnerabilidade que exclui o assentimento dado pela vítima ${ }^{24}$. Mais: a depender da forma como articulamos o conceito de vulnerabilidade, podemos caracterizar a pessoa que migra para prostituir-se voluntariamente como imigrante ilegal (CASTILHO, 2008), o que permite sua criminalização, ainda que a prostituição em si não seja considerada ilegal pelas leis do país de destino. Esses são alguns dos danos colaterais básicos das políticas antitráfico vigentes.

Os conflitos interpretativos não se exaurem no campo da definição do que vem a ser a exploração que enseja a classificação de uma violência como tráfico de pessoas. Estudo recente realizado com a colaboração de Estados-Partes do Protocolo de Palermo iluminou a dificuldade de lidar com o consentimento da vítima (NAÇÕES UNIDAS, 2014). Observou-se que os casos mais complexos, em que se vislumbrava uma violência e a pessoa indicada como vítima atestava ter concordado com a forma de exploração investigada, foram solucionados com amparo na noção de valores. O consentimento não deveria ser considerado quando ultrapassasse valores básicos como a dignidade, a liberdade e a proteção de vulneráveis. Isso era um parâmetro consensual.

A questão era, no campo da exploração sexual, que os valores de dignidade humana poderiam ser utilizados para desconsiderar a validade de qualquer assentimento, sob o pressuposto de que a prostituição, como mercantilização do corpo, não pode ser consentida (NAÇÕES UNIDAS, 2014).

23 'Para estar 'errada', portanto, a exploração precisa estar ligada de alguma forma à injustiça - não apenas tomando vantagem de uma pessoa, de sua situação ou vulnerabilidade, mas tomando uma vantagem injusta. Essa é uma distinção útil, mas com certeza levanta a questão de como a injustiça deveria ser definida ou entendida" (NAÇÕES UNIDAS, 2015, p. 21-22. Tradução livre).

24 Sobre a indefinição conceitual quanto à questão do abuso de posição de vulnerabilidade, contamos com documento temático produzido pelas Nações Unidas (2013). 
Não curiosamente, foi marcado o fato de que o consentimento nos casos de trabalho forçado era investigado de maneira distinta daqueles em que despontava a exploração da prostituição ou outras formas de exploração sexual. Cristalizava-se, por mais esse fator, a permeabilidade da construção social do tráfico de pessoas à questão de gênero. Concluiu-se:

(...) o tipo de exploração relacionado com o tráfico em questão pode fazer uma diferença na forma como as afirmações de consentimento são compreendidas e como ela afeta o processo de justiça criminal [sic]. Geralmente, na maioria dos Estados pesquisados, o papel do consentimento foi apontado como sendo mais complexo em casos de trabalho do que para os casos de exploração sexual. Isso pode se relacionar com diferentes limites legais entre as duas formas de exploração. Em alguns Estados, mesmo que as próprias vítimas fortemente afirmem seu consentimento, ou quando há indícios de consentimento, tais afirmações são desconsideradas em casos de tráfico para exploração sexual. Quando combinado com uma interpretação liberal de meios mais "sutis", como "abuso de posição de vulnerabilidade", torna-se possível acusar, como tráfico, a conduta que possa de outra forma ser considerada como lenocínio ou lucro com a prostituição. Nesses mesmos Estados, uma afirmação semelhante de consentimento por parte de uma vítima do tráfico para exploração de trabalho ou indicações de consentimento pode ser tratada de forma bastante diferente: considerados como altamente relevantes para a questão se o tráfico para exploração do trabalho de fato ocorreu ou não (NAÇÕES UNIDAS, 2014, p. 96).

Portanto, no que se refere à prostituição, embora haja consenso para reconhecer que a atividade em si não configura tráfico, esse discurso pode ter forte componente retórico, já que a validade do assentimento do exercício da prostituição pode ser desqualificada em face de valores morais diversos. Aliás, a tendência é que o assentimento seja desconsiderado em face de outras modalidades de tráfico, como a que envolve trabalhos forçados.

A desconsideração do consentimento nos casos de migração para a realização de serviços sexuais também é possível em razão da identificação da escolha como abuso de situação de vulnerabilidade, independentemente da subjetividade da pessoa que se reputa traficada.

Esse, inclusive, foi um dos temas trabalhados no seminário temático das Nações Unidas sobre a questão do consentimento, ocasião em que foi frisada a possibilidade de que, antes de ler o tráfico pela perspectiva da vítima, fosse feita a leitura a partir da percepção dos agentes do crime acerca do potencial de exploração da pessoa vitimada (NAÇÕES UNIDAS, 2014). A diretriz se conecta com a projeção protetiva de Palermo (NAÇÕES UNIDAS, 2003), mas encerra dúvidas sobre a adequação do marco de segurança aplicado às mulheres. Se, por um lado, há uma facilitação da investigação e punição de casos em que a autonomia da vontade foi suprimida e a exploração da sexualidade feminina efetivamente ocorreu, por outro, toda mulher que migra sem documentos para prostituir-se pode vir a ser considerada 
vítima - com altas chances de repatriação -, independentemente de vislumbrar na prostituição uma atividade laboral conveniente para a realização de seus projetos pessoais.

Conclui-se, assim, que a aferição, em concreto, dos casos de tráfico é permeada por uma construção de gênero que pressupõe assimetrias entre o masculino e o feminino. A mulher parece compartilhar o marco de vulnerabilidade e incapacidade destinado a crianças e adolescentes, como anota Castilho (2013), posição em que a vontade por ela manifestada tem seu valor reduzido, em nome da proteção.

Nesse panorama, cumpre reconhecer a ocorrência de uma viragem do Protocolo de Palermo (NAÇÕES UNIDAS, 2003) com relação ao que se convencionou reprimir sob os auspícios da Convenção de Lake Success (NAÇÕES UNIDAS, 1949). É difícil, no entanto, compreender até que ponto o padrão de neutralidade com relação à prostituição não deixa frestas para a criminalização da atividade por outras vias. A resposta depende da reunião de achados nos campos das políticas de repressão dos agentes, de acolhimento das vítimas e de prevenção primária. Enfim, o aprofundamento quanto ao discurso e às práticas nesses três eixos é que poderá iluminar o papel efetivamente exercido pelo Protocolo de Palermo (NAÇÕES UNIDAS, 2003) no campo das práticas sexuais autônomas e livres.

Observe-se, ainda, que, embora a discursividade sobre as práticas sexuais no contexto migratório tenha sofrido idas e vindas na história da produção normativa internacional, o padrão de discurso atrelado à deportação como válvula de defesa da segurança nacional persiste em Palermo (NAÇÕES UNIDAS, 2003). Independentemente do reconhecimento da condição de vítima de tráfico de pessoas, ao final do processo investigativo, a deportação é ferramenta em poder dos Estados-membros da Convenção Contra a Criminalidade Organizada Transnacional e de seus Protocolos. Isso é o que evidenciam as notas interpretativas da negociação do Protocolo de Palermo em seu item $71^{25}$ (NAÇÕES UNIDAS, 2000).

Esse, também, o achado de Kempadoo (2005) ao observar que as vítimas do tráfico de pessoas recebem, em troca da colaboração com os sistemas de Justiça Criminal acerca de quem são seus traficantes - por vezes pessoas íntimas e familiares que auxiliaram na

\footnotetext{
${ }^{25}$ O item contempla a seguinte redação: “Artigo 6: Assistência e proteção às vítimas de tráfico de pessoas. (...) Parágrafo 3. (...) 71. Nos trabalhos preparatórios se indicará que as palavras 'residência permanente' neste parágrafo deverão ser entendidas no sentido de residência prolongada no país, mas não necessariamente residência indefinida. Este parágrafo deverá ser entendido sem menoscabo do que disponha o direito interno relativamente à outorga do direito de residência ou à duração da mesma" (NAÇÕES UNIDAS, 2000, p. 14. Tradução livre).
} 
promoção de seu deslocamento -, vistos para permanecerem no país de destino apenas no período necessário para conclusão da investigação dos agentes. Acrescenta-se: quando lhes é facultada a permanência no destino, a benesse costuma depender da alocação da vítima dentro do quadro de profissões regulamentadas no país, exigência que não raramente esbarra na continuidade voluntária da migrante no mercado de serviços sexuais.

Decerto que o retorno da vítima pela via da deportação é menos gravoso do que pela da expulsão. Nesse particular, a projeção da mulher como provável vítima de exploração da prostituição e de outras formas de exploração sexual traz um benefício em relação ao simples reconhecimento da migração não autorizada. Com isso, o ato de afastamento da pessoa estrangeira não impedirá seu posterior ingresso no país em que está por vias regulares. Por outro lado, tirante o resultado final, seja pela vitimização por tráfico de pessoas ou pela criminalização da migração indocumentada, o que se verifica ao final dos processos de monitoramento da situação é a devolução ao país de origem, às condições de que partiu inicialmente, independentemente da vontade de permanecer.

Justamente em virtude desses casos é que especialistas da área de tráfico internacional de pessoas, como Piscitelli (2011), narram situações em que Palermo é utilizado como argumento para recrudescer estratégias antimigração e antiprostituição, iluminando caminhos de reflexão acerca do caráter limitado do potencial de gerenciamento das políticas de tráfico de pessoas sob a perspectiva repressiva.

\subsection{O marco brasileiro de enfrentamento ao tráfico de pessoas}

Com referência ao contexto brasileiro, o Protocolo de Palermo (NAÇÕES UNIDAS, 2003) foi internalizado muito rapidamente. Poucos meses após a entrada em vigor do diploma internacional, o Decreto no. 5.017/2003 foi editado para incorporá-lo à ordem jurídica nacional. Todavia, a legislação penal concernente ao tráfico de pessoas se direciona exclusivamente à mobilidade para exercício da prostituição, interna ou internacional ${ }^{26}$ e 27 ,

${ }^{26}$ Como se vê nos Artigos 231 e 231-A do Código Penal Brasileiro (CPB): "Artigo 231: "Promover ou facilitar a entrada, no território nacional, de alguém que nele venha a exercer a prostituição ou outra forma de exploração sexual, ou a saída de alguém que vá exercê-la no estrangeiro. Pena - reclusão, de 3 (três) a 8 (oito) anos. $\S 1^{\circ}$ Incorre na mesma pena aquele que agenciar, aliciar ou comprar a pessoa traficada, assim como, tendo conhecimento dessa condição, transportá-la, transferi-la ou alojá-la. $§ 2^{\text {o }}$ A pena é aumentada da metade se: (...) IV - há emprego de violência, grave ameaça ou fraude. § 3o Se o crime é cometido com o fim de obter vantagem econômica, aplica-se também multa" (Redação conferida pela Lei no 12.015, de 2009).

27 “Artigo 231-A: Promover ou facilitar o deslocamento de alguém dentro do território nacional para o exercício da prostituição ou outra forma de exploração sexual: Pena - reclusão, de 2 (dois) a 6 (seis) anos. § 1으 Incorre na mesma pena aquele que agenciar, aliciar, vender ou comprar a pessoa traficada, assim como, tendo 
mesmo após as modificações legislativas dos anos de 2005 e 2009. Note-se que isso se dá mesmo que, no Brasil, a prostituição seja legal, embora não regulamentada.

A atual disciplina do Código Penal Brasileiro encaixa o tráfico nacional e internacional de pessoas dentro do título referente aos crimes contra a dignidade sexual, no capítulo que se destina a tratar do lenocínio e do tráfico de pessoas para o fim de prostituição ou outra forma de exploração sexual. A topologia da norma, até o advento da Lei no 12.015/2009, era no título dos crimes contra os costumes, no capítulo sobre o lenocínio e o tráfico de mulheres. A alusão a gênero foi cortada na forma da Lei no - . 11.106/2005 e, somente no ano de 2009, ocorreu a inclusão da noção de exploração sexual.

Considera-se vítima de tráfico, atualmente, qualquer pessoa que tenha sua entrada ou saída do país, ou mesmo seu deslocamento interno, promovidos ou facilitados para o exercício da prostituição. Em outras palavras: a migração para a prostituição é aqui entendida como espécie do gênero exploração sexual independentemente da aderência voluntária da suposta vítima para o evento. O elemento subjetivo presente no meio enganoso, fraudulento ou coator são parâmetros considerados apenas no cálculo da pena, para majorá-la. São igualmente apenados o agenciamento e o aliciamento migratório para essa atividade, independentemente de denotarem exploração. Nesse particular, o preceito penal do tráfico de pessoas apenas acrescenta à lógica repressiva do lenocínio, constante dos Artigos 227 a 230 do Código Penal $^{28}$, a ideia da migração.

As bases em que se dá a persecução penal da exploração sexual são amplas. "Hoje o gênero é a exploração sexual, sendo espécies dela turismo sexual, prostituição infantil, pornografia infantil, prostituição forçada, escravidão sexual, casamento forçado" (CASTILHO, 2008, p. 11). E a ideia de exploração da prostituição de outrem, apresentada pelo Protocolo de Palermo (NAÇÕES UNIDAS, 2003), foi substituída pela de prostituição em si, o que gera a distorção de que todo deslocamento para exercício da atividade recebe o rótulo de tráfico. Os problemas da insuficiência e da inadequação do marco penal brasileiro têm sido atribuídos a interesses que "inibem o desenvolvimento de ferramentas que poderiam,

conhecimento dessa condição, transportá-la, transferi-la ou alojá-la. § $2^{\circ}$ A pena é aumentada da metade se: (...) IV - há emprego de violência, grave ameaça ou fraude. § 3o Se o crime é cometido com o fim de obter vantagem econômica, aplica-se também multa." (Redação conferida pela Lei no 12.015, de 2009).

28 “Artigo 227 - Induzir alguém a satisfazer a lascívia de outrem: (...); Artigo 228. Induzir ou atrair alguém à prostituição ou outra forma de exploração sexual, facilitá-la, impedir ou dificultar que alguém a abandone: (...); Artigo 229. Manter, por conta própria ou de terceiro, estabelecimento em que ocorra exploração sexual, haja, ou não, intuito de lucro ou mediação direta do proprietário ou gerente: (...); e, Artigo 230 - Tirar proveito da prostituição alheia, participando diretamente de seus lucros ou fazendo-se sustentar, no todo ou em parte, por quem a exerça: (...)". 
objetivamente, medir condições de exploração em contextos sexuais" (NAÇÕES UNIDAS, 2015, p. 80).

Os Artigos 231 e 231-A do Código Penal parecem, por todo o exposto, objetivamente cegos com relação às diferentes formas de exploração transnacional humanas. $\mathrm{O}$ contraponto com a lógica da migração para atividades que são reconhecidas como trabalho é interessante. É que, na figura típica do aliciamento de trabalhadores com o fim de emigração ${ }^{29}$, está inserido o elemento fraudulento.

Assim, parece evidente que a questão do comércio sexual é acompanhada por assimetrias do sistema penal repressivo que dizem, nas entrelinhas, que a prostituição não é trabalho, muito embora seja classificada como ocupação pelo Ministério do Trabalho e Emprego (CBO/MTE, item 5.198) ${ }^{30}$. Merece registro, ainda, que o recrutamento fraudulento de trabalhadores para a emigração tem pena sensivelmente menos severa que o recrutamento para a prostituição, ainda que consentido.

A previsão penal que enfoca como tráfico internacional de pessoas apenas o aliciamento migratório para fins de comércio sexual invisibiliza o conjunto maior de práticas exploratórias previsto na Política Nacional de Enfrentamento ao Tráfico de Pessoas ${ }^{31}$, que se remete aos tipos mínimos de exploração do Protocolo de Palermo, referindo-se também a trabalho e serviços forçados, escravatura, servidão e remoção de órgãos ${ }^{32}$ e 33 .

Por fim, convém mencionar a tramitação do Projeto de Lei do Senado n⿳o. 479, de 2012, aprovado na casa iniciadora aos 26 de março de 2014, que propõe uma nova abordagem penal do tema. O projeto sobre prevenção e repressão ao tráfico interno e internacional de pessoas e sobre medidas de proteção às vítimas previu, originalmente, a revogação dos Artigos 206, 207, 231 e 231-A do CPB e a tipificação do tráfico em função da exploração, nas diversas formas contempladas por Palermo, com explícita menção ao casamento servil e à adoção ilegal como espécies de servidão e abertura a outras formas de exploração mediante

29 Diz o Artigo 206 do Código Penal Brasileiro: "Recrutar trabalhadores, mediante fraude, com o fim de levá-los para território estrangeiro. Pena - detenção, de 1 (um) a 3 (três) anos e multa".

30 A descrição é a de que as pessoas que laboram nesse setor: "Buscam programas sexuais; atendem e acompanham clientes; participam em ações educativas no campo da sexualidade. As atividades são exercidas seguindo normas e procedimentos que minimizam as vulnerabilidades da profissão".

31 Decreto no- 5.948/2006.

32 Nações Unidas, 2003. Artigo 2 do Protocolo de Palermo.

33 Apesar dos avanços da Política Nacional, não se ignora o fato de que ela ainda falha ao deixar de definir o que é exploração, conceito central para a orientação das práticas de enfrentamento ao tráfico de pessoas no Brasil, como alerta Piscitelli (2012). 
coação, fraude, abuso ou engano que ofendam, de modo relevante, a dignidade da pessoa e sua integridade física.

Referido projeto de lei do senado parece pretender eliminar o pressuposto de que toda prostituição é uma espécie de exploração sexual, contudo, a registro de Castilho (2015), essa lógica discursiva será mantida no título do capítulo e nos Artigos 228 e 229 do Código Penal. Além disso, não há previsão de definição para a exploração sexual no aludido projeto, muito embora essa proposta já possa ser vislumbrada no Projeto do Novo Código Penal (PLS nº 236/2012) do Senado, que a reconhece no ato de "obrigar alguém a exercer a prostituição ou impedir ou dificultar que a abandone". De todo modo, segundo a mesma autora "é provável que a associação de equivalência entre prostituição e exploração sexual continue sendo feita, não só porque ainda terá respaldo no Código Penal, mas principalmente porque é forte no Congresso Nacional a corrente abolicionista da prostituição" (CASTILHO, 2015, p. 10).

Acrescente-se, a título de informação, que tramita, na Câmara dos Deputados, o Projeto de Lei no. 4.211, de 2012, do Deputado Jean Wyllys, que pretende a regulamentação da prostituição e prevê espécies não taxativas de exploração sexual.

Feitas essas considerações preliminares para mapeamento do espaço em que a presente pesquisa se desenvolveu, passo à apresentação pormenorizada da metodologia de análise utilizada e dos achados da investigação.

\subsection{Parâmetros e recortes da pesquisa}

Ao longo da presente exposição registrarei os passos seguidos para a coleta e análise de dados. Também serão expressadas as estratégias de confirmação e validação dos resultados.

Declaro, desde já, no campo das boas práticas de produção científica, que os resultados apresentados fazem parte de investigação inédita e não houve necessidade de submissão prévia da proposta de pesquisa a comitê de ética, especialmente por utilizar-se de material de domínio público.

De todo modo, sob o ponto de vista ético, a investigação apresenta riscos mínimos aos sujeitos envolvidos e foram adotadas todas as cautelas investigativas de praxe. $\mathrm{O}$ compromisso ético sugere a preservação dos nomes das autoras que emergem das sentenças e dos acórdãos, entre eles, eventuais nomes de magistrados, pessoas ofendidas pela conduta 
supostamente criminosa, testemunhas, acusados, bem como dos outros sujeitos cuja identificação possa constar das sentenças e dos acórdãos. Busca-se, por essa via, prevenir quaisquer riscos de hiperexposição ou constrangimento.

Esclareço que a pesquisa recai sobre a discursividade contida em decisões de processos judiciais sobre tráfico internacional de mulheres. A investigação em tela está estritamente focada no discurso que emerge do material analisado, que foi examinado por meio da observação de correlações, frequência de termos e associações de estruturas vernaculares às categorias analíticas previamente elaboradas.

Convém anotar que a menção a locais de partida ou destino das pessoas retratadas como ofendidas nas decisões, caso ocorra, será meramente ilustrativa. A pesquisa não se propõe a fornecer elementos que convirjam para o monitoramento de potenciais rotas de tráfico ou para a identificação de características de vítimas, acusados ou organizações criminosas, dados que não aparecerão de forma estruturada e sistemática nas linhas que seguem, por exorbitarem o recorte da proposta de pesquisa.

Decisões de casos especificamente relativos à exploração de crianças e adolescentes, em todas as suas formas, foram excluídas do âmbito cognitivo desta pesquisa. Procedi à escolha metodológica de eliminação desses casos, porque a investigação tem por objetivo captar a subjetividade das pessoas supostamente ofendidas nos casos narrados, enveredando pelo grau de autonomia que o Poder Judiciário atribui às eventuais escolhas migratórias.

Seria incompatível fazer apreciação desta matéria com crianças e adolescentes sem a devida pontuação e investigação do grau de discernimento e de liberdade dessas pessoas. Igualmente inadequado seria acolher, sem a ponderação que o assunto exige, a ideia de consentimento da vítima para pessoas que ainda estão em formação e não atingiram a barreira biológica da maioridade. Para entrada nessa esfera, seria prefacial investigar o campo de disputas discursivas pertinente, em que são travadas extensas reflexões sobre como proteger o segmento sem deixar de reconhecer crianças e adolescentes como sujeitos de direitos que progressivamente adquirem o protagonismo de suas vidas.

É preciso observar, aliás, que a tutela da sexualidade de crianças e adolescentes não se exaure no campo da repressão das múltiplas formas de violência, por meio da responsabilização dos agressores. Como salienta Fabiana Gorenstein (2009), a proteção não se alcança somente pela limitação progressiva de direitos sexuais e reprodutivos das pessoas menores de idade. Esse é apenas o caminho do controle e da dominação, em nome do qual 
acaba por ser esquecida a necessidade de implementação de direitos em favor de uma sexualidade mais saudável na infância e na adolescência.

De mais a mais, mesmo que a pesquisa fosse limitada ao lado repressivo, seria muito arriscado tentar acessar o pano de fundo normativo-penal do tráfico internacional de crianças e adolescentes para fins de exploração sexual simultaneamente ao dos adultos. O motivo perpassa o fato de que a questão do tráfico internacional de crianças e adolescentes acende discussão complexa, que se abre sobre um universo fático-normativo paralelo.

O Código Penal Brasileiro (Decreto-Lei no. 2.848/1940), na redação atual, chega a englobar expressamente a tutela de crianças e adolescentes na tipificação do tráfico internacional de pessoas para fins de exploração sexual, prevendo causa de aumento de pena de 50\% nessas hipóteses. Entretanto, a proteção penal de crianças e adolescentes em face da exploração sexual internacional está detalhada no Estatuto da Criança e do Adolescente. Ali encontra-se a tipificação de condutas como o envio de criança ou adolescente para o exterior sem observância das formalidades legais ou com intuito de lucro ${ }^{34}$. Também se apresentam as figuras da pornografia infantil ${ }^{35} \mathrm{e}$ da submissão de criança ou adolescente à prostituição e à exploração sexual ${ }^{36}$.

No cotejo das realidades de sujeitos adultos e menores de idade, algum dos lados poderia ser essencializado, em prejuízo da qualidade da investigação. Além disso, tratar as situações sobre crianças e adolescentes sem uma inclinação específica, sem traçar sequer um panorama da complexidade que envolve toda a discussão sobre os direitos sexuais e reprodutivos dessa população, seria, em última instância desvalorizar esses mesmos casos, o que não estaria de acordo com o móvel do estudo.

Justificada a exclusão de casos sobre crianças e adolescentes, observo, sem embargo, que ainda persistiram no universo das decisões selecionadas para a análise discursiva algumas que versavam, cumulativamente, sobre a exploração sexual de pessoas menores de idade.

Os casos representam pouco mais de $10 \%$ do total analisado e não foram excluídos por dois motivos: pela abordagem em separado da ofensa contra a pessoa menor de idade, que permitia exclusão física do trecho; ou, pela inexistência de exploração específica das ofensas narradas contra crianças e adolescentes na decisão judicial, que foram tratadas dentro do

\footnotetext{
34 Artigo 239 do Estatuto da Criança e do Adolescente (ECA).

35 Artigos 240, 241, 241-A a 241-E, do Estatuto da Criança e do Adolescente (ECA).

36 Artigo 244 do Estatuto da Criança e do Adolescente (ECA).
} 
contexto do tráfico de pessoas adultas. Entende-se que, nas duas situações, inexiste contaminação dos elementos discursivos escolhidos, afastando-se qualquer prejuízo ao conteúdo da pesquisa.

Foram considerados igualmente exorbitantes em face dos limites da pesquisa processos relacionados a aliciamento para o fim de emigração, aliciamento de trabalhadores de um local para outro do território nacional e recrutamento de pessoas para realização de trabalhos em condições análogas à escravidão dentro do território nacional. Como esses casos não retratam formas de exploração sexual em primeiro plano, são incapazes de fornecer elementos cognitivos substanciais para o presente estudo.

\subsection{Validade, confiabilidade e consistência do projeto investigativo}

A pesquisa qualitativa tem em foco três exigências enumeradas por Graham Gibbs (2009): validade, confiabilidade e consistência. A validade está associada ao trabalho da pesquisadora de verificar a precisão dos resultados empregando procedimentos específicos. A confiabilidade indica que a abordagem está em paralelo com relação àquela adotada por outras pesquisadoras no campo do Direito. A consistência, por fim, advém da documentação do máximo de etapas possível, além da apresentação de um banco de dados detalhado.

No primeiro capítulo, houve apresentação do presente estudo como pesquisa qualitativa de perfil indutivo e exploratório, que se desenvolve sobre sentenças e acórdãos em processos disponibilizados na base de dados do Escritório das Nações Unidas contra Drogas e Crime referentes a tráfico internacional de mulheres cisgênero. Ali estava a demonstração da validade da pesquisa.

Naquele mesmo capítulo inaugural, foi demonstrada a pertinência e a adequação da opção de recorrer à análise de discurso para exame do conjunto de documentos selecionados, o corpus documental. Esta foi a fase de demonstração da confiabilidade do projeto científico, que passou a se reportar, dali em diante - e com amparo nas lições metodológicas de Michel Pêcheux, Eni Orlandi e Dominique Maingueneau —, à pergunta: como o texto daquelas sentenças e acórdãos se coloca no mundo?

Demarcada a linha condutora de todas as demais indagações que surgiram ao longo do caminho de pesquisa, identifica-se o conjunto de documentos do qual se extraíram os dados utilizados. 
A documentação foi coletada na base de dados referente a casos judiciais de tráfico de pessoas do $\mathrm{UNODC}^{37}$ e abarca todo o material ali disponibilizado até o mês de dezembro de 2015, que se reporta à existência de 78 ocorrências de casos judiciais sobre de tráfico internacional de pessoas no Brasil.

A escolha do material de análise esteve relacionada à oportunidade de traçar um panorama dos elementos discursivos contidos em sentenças e acórdãos penais que falavam sobre tráfico internacional de mulheres. Esse foi o meio eleito para responder a inquietudes pessoais e acadêmicas fundadas na noção prévia de que a objetividade que a lei penal brasileira imprimia à capitulação penal do tráfico de pessoas para fins de exploração sexual não se identificava com a subjetividade da definição do delito no Protocolo de Palermo (NAÇÕES UNIDAS, 2003).

Retomando as explanações do capítulo anterior, observo que a atual redação do Artigo 231, caput, do Código Penal considera crime o ato de "promover ou facilitar a entrada, no território nacional, de alguém que nele venha a exercer a prostituição ou outra forma de exploração sexual, ou a saída de alguém que vá exercê-la no estrangeiro". A aferição da conduta é, portanto, objetiva.

No contraponto, o Protocolo de Palermo (NAÇÕES UNIDAS, 2003) descreve o tráfico de pessoas nos seguintes termos:

a) Por "tráfico de pessoas" entende-se o recrutamento, o transporte, a transferência, o alojamento ou o acolhimento de pessoas, recorrendo à ameaça ou ao uso da força ou a outras formas de coação, ao rapto, à fraude, ao engano, ao abuso de autoridade ou de situação de vulnerabilidade ou à entrega ou aceitação de pagamentos ou benefícios para obter o consentimento de uma pessoa que tem autoridade sobre outra, para fins de exploração. A exploração deverá incluir, pelo menos, a exploração da prostituição de outrem ou outras formas de exploração sexual, o trabalho ou serviços forçados, a escravatura ou práticas similares à escravatura, a servidão ou a extração de órgãos;

b) O consentimento dado pela vítima de tráfico de pessoas tendo em vista qualquer tipo de exploração descrito na alínea a) do presente artigo, deverá ser considerado irrelevante se tiver sido utilizado qualquer um dos meios referidos na alínea a);

c) O recrutamento, o transporte, a transferência, o alojamento ou o acolhimento de uma criança para fins de exploração deverão ser considerados "tráfico de pessoas" mesmo que não envolvam nenhum dos meios referidos na alínea a) do presente artigo;

d) Por "criança" entende-se qualquer pessoa com idade inferior a dezoito anos.

Como ilustra a transcrição, o Protocolo leva em conta elementos como a ocorrência de coação, fraude, engano, abuso de autoridade e situação de vulnerabilidade durante o processo

\footnotetext{
37 Os casos podem ser consultados em https://www.unodc.org. Último acesso aos 31 de jan. de 2016.
} 
de migração internacional. Esses conceitos estão condicionados ao exercício de juízos de valor. Ora, como apontar, por exemplo, fraude e engano sem tomar por base a percepção subjetiva da vítima? Qual seria o impacto dessa objetivação do fenômeno na esfera da persecução jurídico-penal? Se, por exemplo, fraude e engano não são valorados, na lei penal brasileira, para caracterização do tipo penal de tráfico internacional de pessoas para fins de exploração sexual, quais são os reflexos dessa rigidez e objetividade do modelo penal no papel jogado pelo testemunho da pessoa traficada? Na tessitura da sentença ou do acórdão que condena ou absolve existe preocupação com a personalidade, as características pessoais e socioeconômicas das diversas mulheres que ali figuram como alvos do crime?

Mais: era importante descobrir se, como vítima, o Judiciário colocava em primeiro plano a pessoa que eventualmente sofreu o engodo ou a violência. Ou seria a decisão de punir um projeto mais fortemente voltado para a defesa da moral veiculada no Código Penal e da doutrina que o cerca? Será que o Judiciário constrói, de forma expressa ou subliminar, imagens dessas pessoas? E se constrói, que imagens são essas? Os retratos formados ilustram um perfil essencializado ou complexo dessas mulheres?

Havia todo um universo discursivo nos dados que o Escritório das Nações Unidas reúne e disponibiliza para consulta pública em sua página eletrônica. Esse mundo merecia ser conhecido mais de perto sob uma perspectiva de gênero: essa foi a aposta da pesquisa.

O projeto foi levado a efeito sobre dados secundários, firme na idoneidade da seleção anteriormente realizada pelo UNODC em parceria com o Conselho Nacional de Justiça CNJ. Denominada Case Law Database, a plataforma do UNODC reúne decisões judiciais de diversos países, orientadas, em última instância, para o marco internacional do Protocolo de Palermo (NAÇÕES UNIDAS, 2003).

No Brasil, os documentos do banco de dados do UNODC referem-se a julgados em primeira ou segunda instância no período fundamentalmente compreendido entre $1^{\circ}$ de março de 1996 e 31 de agosto de 2012. A Case Law Database passa, atualmente, por atualização e os julgados lançados no ano de 2016 não puderam sem incluídos. Não obstante, a amostra é, ainda assim, representativa, por recolher, de forma homogênea, dados de todo o Judiciário nacional, sem discriminação de Juízos, estados ou regiões, até dezembro de 2015.

Atribui-se a sua pertinência, ainda, ao fato de poder consolidar reflexões que permitam aprofundamento ulterior, com expansão e atualização do corpus de análise, utilização 
eventual de métodos quantitativos ou mistos de pesquisa, bem como com agregação de novas categorias analíticas que porventura emerjam.

Por fim, a descrição das etapas da investigação subjacente preenche o último prerrequisito eleito por Graham Gibbs (2009) como essencial para a pesquisa qualitativa: a consistência.

Nesse intuito, realizei uma leitura prévia e integral do material, que auxiliou na formulação de hipóteses e estimulou uma reflexão preliminar sobre a qualidade das decisões e a viabilidade de utilizá-las como instrumento de análise do discurso judicial sobre tráfico internacional de mulheres cisgênero. Daí, seguiram-se seis grandes etapas.

A primeira delas, de caráter preparatório, consistiu em uma releitura livre de todos os documentos brasileiros disponíveis na base de dados da UNODC, com objetivo de extrair impressões acerca de seu conteúdo, traçar hipóteses iniciais que direcionassem o estudo e identificar as teorias que se adéquam ao material examinado.

A segunda centrou-se no aprofundamento teórico com relação ao tráfico de pessoas para eleição de unidades de registro relevantes dentro dos textos selecionados, os termos-pivô, na terminologia de Michel Pêcheux. Ao final desta etapa, pude criar as categorias analíticas pertinentes aos objetivos do projeto.

A terceira etapa desdobrou-se em dois momentos. O primeiro foi o do recorte fundamentado do material que formaria o corpus de análise. O segundo, o da seleção de casos que apresentavam densidade de conteúdo compatível com a análise pretendida. Ao final, foi feita a recuperação, em formato digital, das decisões analisadas qualitativamente, comprobatórias da consistência do estudo.

$\mathrm{Na}$ quarta etapa, foi feita, em meio manuscrito, a microanálise do material, pela marcação, linha a linha, de destaques dos termos-pivô agregados na segunda etapa e dos trechos substancialmente mais densos.

Sucedeu-se a exploração do material, com administração sistemática dos controles de frequência dos indicadores, exame de correlações e extração de trechos discursivos específicos para ampliação qualitativa da fase de resultados com relação às categorias de análise preestabelecidas. Nisso consistiu a quinta etapa.

Superada a fase de mensuração de dados por frequência e do estabelecimento de correlações, passou-se à sexta e última etapa do método. Concluí a análise do discurso 
mediante investigação do comprometimento simbólico e político (ORLANDI, 2007) da mensagem difundida pelo corpus documental. Esta fase foi marcada pela expansão das conclusões para além do texto e avaliação de como o discurso nele veiculado se apresenta no intertexto, isto é, na realidade das narrativas brasileiras sobre tráfico de pessoas e gênero.

\subsubsection{Metodologia de seleção dos documentos}

Trabalhando já sobre a base do UNODC, observei haver, dentro do catálogo, casos repetidos e outros com mais de uma decisão anexada. Diante disso, o número final de decisões examinadas foi de 81 .

Passei à fase de leitura complementar dos casos selecionados, momento em que foram excluídos 21 Habeas Corpus ${ }^{38}, 2$ Revisões Criminais ${ }^{39}, 2$ Recursos em Sentido Estrito ${ }^{40}, 2$ acórdãos em Embargos de Declaração ${ }^{41}$ e 1 Termo de Audiência ${ }^{42}$.

Os Habeas Corpus têm o papel constitucional de resguardar o direito de locomoção da paciente $^{43}$. Funcionam como socorro imediato em vista da potencial ou efetiva constrição ilegítima ou abusiva do direito de liberdade das pessoas. Por essa razão, não costumam veicular matérias que demandem investigação mais profunda sobre o mérito propriamente dito da causa penal subjacente.

O mesmo ocorre com as Revisões Criminais, cujas hipóteses de cabimento estão restritas (i) à contrariedade da sentença condenatória em face do texto expresso da lei ou da evidência dos autos; (ii) ao caso em que a sentença condenatória estiver escorada em depoimentos, exames ou documentos comprovadamente falsos; ou (iii) quando se descobrirem provas novas da inocência do condenado ou circunstância que "determine ou autorize diminuição especial da pena" ${ }^{44}$. Aqui, como visto, a cognição horizontal dos fatos encontra limitações incompatíveis com a imersão profunda no mérito da causa já decidida.

O Recurso em Sentido Estrito tem seu cabimento limitado às situações taxativamente enumeradas no Código de Processo Penal, as quais, numa aproximação grosseira, apresentam

\footnotetext{
${ }^{38}$ Documentos 37, 38, 39, 40, 41, 43, 44, 45, 46, 47, 48, 49, 50, 51, 52, 53, 54, 55, 56, 57 e 58; Apêndice C.

39 Documentos 59 e 60; Apêndice C.

40 Documentos 61 e 62; Apêndice C.

41 Documentos 63 e 64; Apêndice C.

42 Documento 65; Apêndice C.

43 Artigo 5o-, LXVIII, da Constituição Federal de 1988.

$44 \mathrm{Na}$ forma do Artigo 621, incisos I, II, III, do Código de Processo Penal (Decreto-Lei no. 3.689/1941).
} 
efeitos semelhantes aos de meras decisões incidentes, não devolvendo ao juízo recorrido o exame exauriente do mérito do processo (OLIVEIRA, 2012) ${ }^{45}$.

Os Embargos de Declaração, por sua vez, têm utilidade restrita à discussão de obscuridade, ambiguidade, contradição ou omissão na Justiça Criminal comum ${ }^{46}$. Apenas excepcionalmente esses recursos podem, acolhidos, levar à modificação do julgado, acrescentando conteúdo ao provimento jurisdicional ao qual se opõem. Ocorre que, nas duas situações em que a base de dados utilizada apresentou acórdãos em Embargos de Declaração, houve rejeição do pedido, com manutenção da decisão anterior, eliminando a utilidade do material para a pesquisa.

Por fim, o Termo de Audiência de Instrução e Julgamento contido no Case Law Database do UNODC cuida, de forma muito sucinta, da absolvição da acusada, em acolhimento da manifestação do Ministério Público Federal e não esclarece com densidade suficiente os elementos concretos de convicção que motivaram o julgamento.

Havia 2 sentenças e 1 acórdão fundados em prescrição e que, por não apresentarem elementos para análise do discurso judicial, tiveram de ser excluídos. A primeira das sentenças foi proferida ainda na fase de inquérito policial, que precede a fase Judicial da persecução penal ${ }^{47}$. A segunda foi lavrada mais de onze anos após o recebimento da denúncia, situação na qual o magistrado competente entendeu, sumariamente, caber reconhecimento da prescrição em perspectiva por economia processual ${ }^{48}$. O acórdão, de outra parte, emanado do Tribunal Regional Federal da 5- Região, cuidou de reconhecer a prescrição retroativa da pretensão punitiva da acusada, cuja pena arbitrada em sentença não havia ultrapassado 4 anos e não foi alcançada pelas alterações da Lei n-. 12.234/2010, a qual afetou a contagem de prazos prescricionais entre a data do fato e a do recebimento da denúncia ${ }^{49}$.

Na mesma situação dos julgados referentes à prescrição, justificou-se a eliminação de sentença declaratória da extinção da punibilidade do acusado de um dos processos por morte $^{50}$. A decisão não trazia elementos discursivos consistentes para a presente investigação.

A modalidade de tráfico sobre a qual se debruçavam os processos que integraram o corpus documental também foi utilizada como parâmetro de exclusão de casos que não

\footnotetext{
45 Artigo 581 do Código de Processo Penal (Decreto-Lei no. 3.689/1941).

46 Artigo 382 do Código de Processo Penal (Decreto-Lei no. 3.689/1941).

47 Documento 66; Apêndice C.

48 Documento 67; Apêndice C.

49 Documento 68; Apêndice C.

50 Documento 69; Apêndice C.
} 
estivessem essencialmente relacionados à persecução penal brasileira ao tráfico internacional de mulheres cis, como esclarecido ao início do capítulo. A leitura atenta de todos os casos elencados permitiu identificar situações de tráfico de crianças e adolescentes, a totalizarem 4 processos, majoritariamente relacionados à exploração sexual ${ }^{51}$. Esses casos, associados aos 2 outros processos que descreviam o aliciamento para trabalho no exterior e o recrutamento nacional de pessoas para realização de trabalhos em condições análogas à escravidão ${ }^{52}$ foram separados do material submetido à análise discursiva.

Uma sentença de absolvição em caso de produção e envio de fotos pornográficas ao exterior foi descartada em virtude do não enquadramento da conduta, pelo Poder Judiciário, como tráfico internacional de pessoas ${ }^{53}$. Além dela, houve casos eliminados por não estarem disponíveis os respectivos arquivos eletrônicos na base de dados utilizada ${ }^{54}$.

Por fim, cumpre esclarecer que, de todas as situações de tráfico examinadas, apenas uma se referia ao ingresso de mulher cis estrangeira no país. Tratava-se de uma argentina que veio com a promessa de realizar trabalhos domésticos e se defrontou com tentativa de exploração sexual. O processo foi mantido na base de dados porque, embora fizesse referência à imigração e não à emigração, partilhava dos mesmos elementos discursivos dos casos em que as mulheres ofendidas eram de nacionalidade brasileira e tentaram ou lograram emigrar ${ }^{55}$.

Procedidos os cortes, restaram 33 processos, aos quais se reportam 36 documentos, que encontram-se repartidos em 25 sentenças e 11 acórdãos ${ }^{56}$.

${ }^{51}$ Documentos 70, 71, 72 e 73; Apêndice C.

52 Documentos 74 e 75; Apêndice C.

53 Documento 76; Apêndice C.

${ }^{54}$ Documentos 42, 77, 78, 79, 80 e 81; Apêndice C.

55 Documento 3; Apêndice C.

$56 \mathrm{O}$ rol de processos submetidos à análise: Sentença 2006.30.00.000871-5 (DOC. 1), Sentença 2006.33.00.005669-9 (DOC. 2), Sentença 1999.71.03.001519-4 (DOC. 3), Apelação Criminal 1999.71.03.001519-4 (DOC. 4), Sentença 2004.61.20.001211-9 (DOC. 5), Sentença no Processo 97.13.01451-0 (DOC. 6), Apelação Criminal 2003.60.04.000915-4 (DOC. 7), Sentença 000882169.2011.403.6181 (DOC. 8), Sentença 2001.38.03.002448-8 (DOC. 9), Sentença 2005.83.00.0068866-8 (DOC. 10), Sentença 2009.84.00.005367-8 (DOC. 11), Sentença 6682.72.2010.405.8300 (DOC. 12), Sentença 2001.71.03.001661-4 (DOC. 13), Sentença 2005.70.03.005598-2 (DOC. 14), Sentença 2005.72.09.000609-8 (DOC. 15), Apelação Criminal 0001389-24.2002.4.03.6113 (DOC. 16), Apelação Criminal 2005.03.99.009508-0 (DOC. 17), Sentença 2004.38.03.009328-4 (DOC. 18), Apelação Criminal 000170358.2007.4.03.6124 (DOC. 19), Sentença no Processo 896379.2002.4.05.8300 (DOC. 20), Sentença 89.0040455-5 (DOC. 21), Apelação Criminal 96.03.087722-0 (DOC. 22), Sentença no Processo 2001.81.00.016360-1 (DOC. 23), Apelação Criminal 0007379-88.2000.4.03.6105 (DOC. 24), Sentença 2001.83.00.007512-0 (DOC. 25), Apelação Criminal no Processo 2001.83.0000.7512-0 (DOC. 26), Sentença 98.21262-0 (DOC. 27), Sentença no Processo 197929.2004.4.05.8100 (DOC. 28), Sentença 000668960.2007.4.05.8400 (DOC. 29), Sentença 2005.70.00.032242-8 (DOC. 30), Sentença no Processo 2004.81.00.18889-0 (DOC. 31), Sentença no Processo 2005.81.00.003813-6 (DOC. 32), Apelação Criminal no Processo 2004.81.00.018889-0 (DOC. 33), Apelação Criminal 2005.61.19.004841-3 (DOC. 34), Apelação 
As sentenças são instrumento de julgamento pelo juiz de primeira instância da própria pretensão punitiva. Permitem ao julgador conhecer e pronunciar-se amplamente sobre os elementos da ação penal pública persecutória de tráfico de pessoas para fins de exploração sexual. Do mesmo modo, os acórdãos em apelação criminal têm aptidão para devolver amplamente ao conhecimento do órgão judiciário de segunda instância a apreciação dos elementos da causa. É em virtude do potencial substantivo que essas duas classes de decisões jurisdicionais apresentam que deu-se a eleição de ambas para o estudo qualitativo.

Adianto que, a princípio, cogitei de fazer uma separação entre o conteúdo veiculado nas sentenças e nos acórdãos, para posterior enquadramento nas cinco categorias apresentadas. A proposta estava amparada na hipótese de que as sentenças provavelmente trariam maior densidade de conteúdo discursivo que os acórdãos das apelações criminais. Isso porque pressupus, ao início do trabalho, que o fato de os magistrados de primeira instância apreciarem, de forma inaugural, os fatos narrados acrescentaria mais caldo substantivo para a análise da mensagem propagada em sentença.

A hipótese, no entanto, não se confirmou no universo de documentos selecionados. Não se justificava traçar uma linha divisória entre as sentenças e os acórdãos investigados, por inexistir uma assimetria efetiva entre ambos no contexto dos elementos codificados e da subsunção às categorias analíticas utilizadas. Assim é que o resultado da pesquisa não se atribui apenas ao discurso dos tribunais ou ao dos juízos federais de piso, mas é o extrato comum da produção de ambas as instâncias discursivas.

Outra proposta levantada durante a projeção do estudo esteve associada à repartição dos julgados no tempo, em razão da introjeção do Protocolo de Palermo na ordem jurídica nacional, na forma do Decreto no. 5.017, de 12 de março de $2004^{57}$, e das modificações legislativas pelas quais passou o Artigo 231 do Código Penal na última década. Refiro-me, mais especificamente, às Leis n⿳o. 11.106/2005 e n⿳⺈. 12.015/2009.

Foi então que pensei na exclusão dos 3 processos cujas sentenças foram prolatadas antes da vigência do Protocolo de Palermo (NAÇÕES UNIDAS, 2003). A justificativa para esse recorte seria a de que os provimentos jurisdicionais anteriores à internalização de Palermo no ordenamento jurídico nacional não serviam como marco analítico para a

Criminal 2004.83.00.007499-2 (DOC. 35) e Sentença no Processo 2004.83.00.007499-2 (DOC. 36). Os documentos 1 a 36 integram o Apêndice B da dissertação.

57 O protocolo foi aprovado na Assembleia-Geral da Organização das Nações Unidas em 15 de novembro de 2000. Colocado à disposição dos Estados-membros para assinatura na sequência, teve sua vigência iniciada em 25 de dezembro de 2003. 
utilização do parâmetro normativo internacional atualmente existente, do qual emerge uma definição de tráfico com componentes valorativos da subjetividade das vítimas.

Porém, para que essa opção fosse viável, a lei de regência do tempo do crime deveria ser a mesma lei penal aplicada na data da sentença. Ocorre que, com o recrudescimento sucessivo do dispositivo penal que trata do tráfico internacional de pessoas para fins de exploração sexual, teve vez a ocorrência de fenômeno diverso: o da extra-atividade da lei penal mais benéfica, que projeta efeitos para o futuro em defesa da pessoa acusada. Com isso, o pressuposto da identidade entre a lei do tempo da conduta criminosa e o da sentença não se confirmou.

Por outro prisma, o dado preliminar que emergiu dessa tentativa frustrada de repartição das decisões no tempo foi o de que, ao inverso das expectativas originais, não existiu alteração sensível nos componentes das sentenças em paralelo com a modificação dos parâmetros legais de capitulação do tráfico de mulheres cis. Aliás, um exemplo disso é que, mesmo numa análise superficial de predominância dos termos "tráfico de mulheres" e "tráfico de pessoas", fica demonstrado que, desde o advento da Lei no-. 11.106/2005, a remissão a "tráfico de mulheres" só foi atualizada para "tráfico de pessoas" e adotada com predominância na metade das decisões ${ }^{58}$.

Decerto que a atualização da terminologia não seria mandatória nos casos analisados, tendo em vista a seleção justamente daqueles provimentos jurisdicionais que se reportam ao tráfico internacional de mulheres cis. Mas o interessante é notar que, mesmo havendo a possibilidade de adoção predominante do termo mais recente, orientado a pessoas de todos os gêneros, parcela significativa dos julgadores manteve-se fiel à terminologia tradicionalmente adotada e reproduzida na doutrina majoritária, num exercício simplificador que pode redundar na reafirmação do fenômeno do tráfico para fins de exploração sexual como algo intrinsecamente associado à figura da mulher cisgênero.

Afastados os motivos que poderiam ensejar a separação apriorística das sentenças em anteriores ou posteriores à internalização do Protocolo de Palermo ou à edição das Leis no․ 11.106/2005 e no. 12.015/2009, procedi à análise qualitativa das 36 decisões em bloco monolítico.

${ }^{58}$ Documentos 6, 7, 10, 16, 17, 19, 20, 24, 25, 28, 31, 32, 34, 35 e 36; Apêndice B. 


\subsection{Análise do corpus documental e achados de pesquisa}

As políticas públicas de enfrentamento ao tráfico de pessoas costumam fazer referência ao controle judicial, especialmente quando estão em pauta os desdobramentos repressivos de notícias de tráfico obtidas pelas autoridades nacionais. E, justamente porque o Poder Judiciário é uma instância de referência no assunto, é importante que o ato de julgar minimize preconceitos de origem, raça, sexo, cor, idade ou quaisquer outras formas de discriminação ${ }^{59}$. Diante desse objetivo Republicano, tem relevo o monitoramento de discursos e práticas que invisibilizam relações e subjetividades no contexto do tráfico e possivelmente alimentam relações de gênero assimétricas.

No campo da produção científica, pensar sobre o método empodera, afirma Katharine Bartlett (2011). Sob essa perspectiva, a autora propõe que as pesquisas feministas traduzam formas de questionar as convenções legais dominantes e desenvolver convenções alternativas que tomem em consideração experiências e necessidades das mulheres. Recomenda, então, a adoção de três etapas pela pesquisadora que pretende produzir conhecimento na seara do feminismo:

(1) identificar e questionar aqueles elementos da doutrina legal existente que excluem ou põem em desvantagem as mulheres e membros de outros grupos excluídos (fazer a pergunta pela mulher); (2) racionalizar a partir do ideal de que as soluções jurídicas são respostas pragmáticas a dilemas concretos antes que escolhas estáticas entre perspectivas contrárias (...) (racionalidade prática feminista); e (3) buscar conhecimentos profundos e perspectivas ampliadas através de compromissos colaborativos ou interativos com outros, baseados na experiência e nas narrativas pessoais (aumento de consciência) (BARTLETT, 2011, p. 23. Tradução livre).

A pergunta pela mulher foi feita ao longo de todo o processo de leitura e sistematização do conteúdo das sentenças e dos acórdãos em apelação criminal. Aliás, a própria ideia de seleção do material com recorte sobre os casos de tráfico internacional de mulheres cisgênero teve por objetivo facilitar a identificação de elementos do discurso jurídico-penal que colocam a mulher em posição de subalternidade.

Conhecendo, de forma analítica, as tramas discursivas que emergem das decisões, pretendi, num salto ulterior, direcionar e ampliar os resultados para a busca de soluções práticas que possam contribuir para inverter a lógica de subalternidade subjacente ao discurso

59 Constituição Federal de 1988, Artigo 3ㅇ․ 
andro-cis-heteronormativo dominante da realidade sociopolítica e do sistema jurídico como um todo.

A opção por seguir as etapas enumeradas no método de Bartlett (2011, p. 24) repousa sobre a compreensão maior de que a apreciação substantiva dos elementos daquelas sentenças e acórdãos pode favorecer uma crítica consistente e fundamentada das regras postas no jogo discursivo do sistema jurídico-penal de tutela da sexualidade feminina. As soluções jurídicas respondem de forma prática aos dilemas da vida em sociedade e passam a integrar essa mesma vida que pretendem regular.

Essa conectividade circular pede a leitura da atuação do Judiciário como algo que, embora se pretenda neutro, isonômico e imparcial - como grande parte da produção científica desde o Iluminismo —-, está completamente embebido do componente cultural circundante. Cumpre então ler o conteúdo do material pesquisado buscando entrelaçá-lo com o campo discursivo que o abarca, tomando o cuidado de assinalar pontos em que palavras, expressões e silêncios dizem mais do que parece à primeira vista.

Cuida-se de enveredar pelos componentes latentes da mensagem, perpassar a figura de quem enuncia, questionar a quem o enunciado se dirige. Pensar as relações que a enunciação da sentença e do acórdão inaugura, rompe, alimenta e em que medida nega a neutralidade da produção jurisdicional na esfera da repressão penal.

Recorrer a decisões judiciais para analisar os meandros desses enunciados e investigar como eles se colocam no mundo é, ainda, dar visibilidade a esse material. Uma visibilidade que pretende controlar, pelo viés social e acadêmico, a produção institucional do Judiciário, enquanto Poder que, no regime democrático nacional, tem por tarefa proteger, antes da moralidade dominante, a cidadania, a dignidade da pessoa humana e o valor social do trabalho ${ }^{60}$.

De mais a mais, o acompanhamento crítico do afazer Judiciário parte desse mesmo compromisso das cidadãs mulheres com a democracia, pois, como bem lembra Sousa Junior (2008), um Judiciário conservador é incompatível com a perene reformulação de direitos e práticas próprios da experiência democrática.

Pensar o lugar da prostituição e da exploração sexual nos casos perseguidos pela Justiça brasileira é uma das formas de aprofundamento nos meandros do tráfico de pessoas. Afinal, se ocorre grave ofensa à dignidade sexual da pessoa humana no contexto migratório,

${ }^{60}$ Constituição Federal de 1988, Artigo 1ํ. 
não há dúvidas de que medidas precisam ser tomadas para reparar o dano. Não obstante, investigar, sistematicamente, ferramentas adequadas para enfrentar a questão de modo profilático e holístico é etapa que precede a elaboração de plataformas de ação política e de produção de normas para enfrentar o problema.

Pautar, criticamente, inconsistências, contradições, estereótipos e assimetrias do discurso dominante, com seus fluxos e influxos, são os eixos do processo de análise discursiva que orientaram a pesquisa subjacente.

O tráfico de pessoas é construção sócio-histórica, cujos primeiros traços se destacaram na primeira década do século XX. Esse constructo está fortemente permeado pelo componente de gênero, seja em virtude de suas origens, seja por força da continuidade, no tempo, de padrões culturais e estereótipos que nele vertem elementos. Sabendo disso, noto que, ao introduzir certos códigos no texto da decisão judicial, a pessoa que julga ativa componentes da memória institucional e social e desativa outros, produzindo o seu esquecimento e fazendo o discurso predominante variar no tempo (ORLANDI, 2007) ${ }^{61}$.

Essa foi a razão pela qual, mediada pelo campo de pesquisas já realizadas sobre tráfico de pessoas, identifiquei códigos cuja frequência e forma de aparecimento nas decisões seria potencialmente capaz de indicar regularidades no padrão de julgamento adotado pelo país. Os códigos foram: mulher, tráfico de pessoas, exploração sexual, prostituição, prostituta, pessoa traficada e vítima. A identificação de cada um deles foi permanentemente acompanhada pelas noções de violência e de estereótipo de gênero.

A violência e a violação de direitos humanos diferem do crime. A distinção analítica entre esses dois planos é feita por Piscitelli (2008, p. 56):

O crime implica a tipificação de abusos, a definição das circunstâncias envolvidas nos conflitos no plano jurídico. A violência é um termo aberto a disputas de significado, que implica o reconhecimento social mais amplo, não apenas legal, de que certos atos constituem abuso.

Estereótipo de gênero, aqui, é compreendido a partir da leitura que Debora Diniz faz do livro Gender stereotyping: transnational legal perspectives, de Rebecca Cook e Simone Cusack. Figura como "visão abrangente ou preconceituosa de atributos ou características que alguns grupos de indivíduos possuem ou mesmo que a sociedade espera que possuam" (COOK, 2012, p. 12).

${ }^{61}$ Não por outra razão, Orlandi (2007, p. 10) leciona que investigar discursividades é mergulhar num duplo jogo de memória: "o da memória institucional que estabiliza, cristaliza, e, ao mesmo tempo, o da memória constituída pelo esquecimento, que é o que torna possível o diferente, a ruptura, o outro”. 
Os estereótipos podem também ser compreendidos como formas de essencialização da identidade e de naturalização de relações sociais e, sob esse ponto de vista, não traduzem automaticamente formas injustas de discriminação no campo do gênero. A questão que se coloca é a de captar as práticas de estereotipagem judicial que redundam em opressão de gênero, refletindo-se no direito de migrar e de dispor autonomamente do próprio corpo. Sob o manto da prática de luta feminista de Cook, pretendo, por ora, contribuir para erradicar uma eventual estereotipagem injusta e opressora do Poder judiciário na esfera do tráfico de mulheres cis, em uma análise que correlaciona os termos-pivôs colhidos com as categorias de análise.

As categorias de análise são lentes para leitura e interpretação dos códigos selecionados. São a marca do discurso e da subsunção histórico-social em que se poderá realizar a interpretação discursiva. Conforme já esclarecido, a análise de discurso não se atém apenas ao textual, mas procura compreender o contexto por trás dos termos-pivô, em que medida eles se conectam com o emissor e o que sua utilização denota sobre o posicionamento tomado, acreditando-se que o texto nunca é neutro ou alheio às construções socioculturais.

As categorias analíticas aqui apresentadas carregam, em si, a discussão sobre sua própria desconstrução. A conexão realizada entre o texto e a categoria de análise, portanto, pode chegar à conclusão de que os códigos a integram em relevância para afirmá-la como integrante do discurso social hegemônico ou não.

Portanto, o padrão de alocação de cada um dos termos-pivô nas decisões foi observado criteriosamente com o objetivo de mapear quando cada um deles dialogava com as cinco categorias de análise enfocadas no estudo: (i) prostituição como exploração sexual; (ii) auxílio à migração para prostituição como tráfico de pessoas; (iii) exercício da prostituição como degradação moral; (iv) mulher cisgênero migrante como vítima; e (v) migração para prostituição como ingenuidade ou vulnerabilidade.

A categoria prostituição como exploração sexual foi registrada para facilitar a compreensão de quais sentenças e acórdãos produziam a equiparação expressa entre essas duas realidades. Trata-se, portanto, de uma categoria analítica atrelada a uma visão objetiva da prostituição como não trabalho, que desconsidera, nesse tocante, qualquer possível vontade autônoma de comercializar serviços sexuais.

De acordo com as lições de Adriana Piscitelli (2008, p. 46), a exploração sexual 
(...) é uma expressão sobre cujo conteúdo não há acordo no debate. As linhas abolicionistas consideram exploração sexual qualquer modalidade de prostituição, inclusive as que envolvem mulheres adultas que estabelecem contratos consensuais e trabalham de maneira autônoma (Barry, 1997). Já as abordagens que apoiam organizações de trabalhadoras do sexo não consideram a prostituição, em si, sinônimo de exploração (Jasmin, 1993; McClintock, 1993). Elas percebem a exploração como uma possibilidade aberta pelas características do mercado de trabalho, que se intensifica no âmbito do capitalismo globalizado (Kempadoo, 1998).

Em meio à indefinição do que pode ser considerado exploração sexual, o conceito de tráfico contido no Protocolo de Palermo ${ }^{62}$ (NAÇÕES UNIDAS, 2003) faz referência à “exploração da prostituição de outrem ou outras formas de exploração sexual".

Ao definir tráfico de pessoas nesses moldes, o Protocolo se antepõe à visualização da prostituição apenas como atividade embasada mercantilização do uso sexual do corpo que decorra de determinação pessoal, consciente e livre ${ }^{63}$. Admite, por corolário, que o conceito de prostituição possa ser articulado como espécie de exploração sexual, integrando a prostituição em si a um campo semântico normativo mais fortemente associado à noção de violência, em paralelo com as linhas abolicionistas retratadas por Piscitelli (2008).

Trilhando caminho semelhante ao adotado no Protocolo de Palermo (NAÇÕES UNIDAS, 2003), identifiquei haver decisões que edificavam uma identidade entre as noções de prostituição e de exploração sexual, usando uma e outra de forma intercambiável ${ }^{64}$. Outro marcador da aproximação semântica entre os conceitos estava no uso de expressões como “exploração da prostituição", "obrigou à prostituição", "obrigadas a se prostituírem" ${ }^{65}$. Nessas situações, que equivaleram a mais de $20 \%$ do total, a prostituição foi tomada como espécie em relação ao gênero exploração sexual, num jogo discursivo de associação entre prostituição e violência.

Esse tipo de associação tem como característica a versatilidade de não dizer, necessariamente, que toda prostituição é exploração, nem desdizê-lo à interlocutora. A mensagem, por ser dúbia, pode ser utilizada, sem maior contestação, para fortalecer a percepção social hegemônica, calcada numa visão androcêntrica e heteronormativa, de que a prostituição é incompatível com a opção livre e autônoma da pessoa que se prostitui, tratandose, sempre e necessariamente, de espécie do gênero exploração da sexualidade.

\footnotetext{
${ }^{62}$ Artigo 3, a, do Protocolo de Palermo (NAÇÕES UNIDAS, 2003).

63 Essa perspectiva de observação da prostituição tem maior proximidade com a vertente do regulamentarismo da profissão.

64 Documentos 33 e 34, Apêndice B.

65 Documentos 10, 12, 19, 21, 25, 27, 28 e 30; Apêndice B.
} 
Evidência mais clara disso são as decisões nas Apelações Criminais 2004.81.00.018889-0 e 2005.61.004841-3 ${ }^{66}$, proferidas pelos Tribunais Regionais Federais da 5 - e 3 - Regiões, respectivamente. Em ambas, não houve qualquer relato de fraude, engano ou violência, mas foi utilizada a expressão "exploração sexual" pelo Poder Judiciário para fazer remissão à prostituição das ofendidas. Essa, parece, é uma das grandes armadilhas discursivas que envolvem o intercâmbio aparentemente ingênuo ou mesmo o escalonamento como gênero e espécie dos conceitos de prostituição e exploração sexual.

\section{A próxima categoria é auxílio à migração para a prostituição como tráfico de} pessoas. Por trás de sua eleição, esteve o interesse em testar a hipótese de pesquisa consistente na afirmação de que a lei penal brasileira que tipifica o tráfico internacional de pessoas gera, na prática, a igualação dessas duas questões. Eventualmente confirmada a hipótese, haveria espaço para debater os reflexos da tomada de um elemento pelo outro no contexto migratório.

Do total das decisões analisadas, aproximadamente 40\% revelam uma equiparação entre auxílio na migração para a prostituição — do qual é espécie o contrabando de migrantes $^{67}$ - e tráfico internacional de mulheres ${ }^{68}$. O argumento de que o consentimento é irrelevante para a caracterização da tipicidade penal esteve presente na metade desses documentos ${ }^{69}$, inclusive em situações de tentativa em que a fala da vítima havia sido transcrita nos autos e não trazia nenhuma evidência de ameaça, uso da força, coação, rapto, fraude, engano, abuso de autoridade, aproveitamento de situação de vulnerabilidade ou compra do consentimento ${ }^{70}$.

Evidência desse entendimento, transcrevo a fundamentação de um dos julgados que verberaram a orientação descrita:

TRÁFICO DE MULHERES (...). CRIME QUE SE CONSUMA COM A MERA FACILITAÇÃO DA SAÍDA DE MULHER DO TERRITÓRIO NACIONAL PARA O EXERCÍCIO DA PROSTITUIÇÃO. IRRELEVÂNCIA DA VONTADE DA VÍTIMA OU DE SUA CONDIÇÃO PRÉVIA DE MERETRIZ NA CARACTERIZAÇÃO DA FORMA BÁSICA.

\footnotetext{
66 Documentos 33 e 34; Apêndice B.

67 "O Contrabando de Migrantes é um crime que envolve a obtenção de benefício financeiro ou material pela entrada ilegal de uma pessoa num Estado no qual essa pessoa não seja natural ou residente". Definição extraída do endereço eletrônico do UNODC, em consonância com o Protocolo contra o Contrabando de Migrantes por via Terrestre, Marítima e Aérea (Protocolo dos Migrantes).

${ }^{68}$ A associação genérica pode ser observada nos Documentos 2, 4, 13, 14, 15, 17, 18, 19, 20, 21, 22, 25, 26, 34 e 36; Apêndice B.

${ }^{69} \mathrm{O}$ consentimento é manifestamente afastado como causa de descaracterização do tráfico internacional para fins de exploração sexual na narrativa judicial dos Documentos 2, 13, 14, 21, 25, 26 e 28; Apêndice B.

70 Documentos 2, 13 e 18; Apêndice B.
} 


\section{(...)}

Pouco importa fosse ou não a vítima pessoa dedicada ao meretrício em João Pessoa, ou estivesse ou não ciente da natureza da atividade que desenvolveria em território espanhol. $\mathrm{O}$ crime de que aqui se cuida não tem necessariamente a fraude como elemento integrante do tipo. Para sua configuração, inexiste a necessidade de que a vítima tenha sido induzida em erro através da oferta de condição inexistente de trabalho ou a algo que não se irá cumprir.

O mero fato de ter emprestado dinheiro à (...) [para] que ela custeasse sua viagem à Espanha, o que está acima de questionamento, já é suficiente para tonalizar o verbo núcleo "facilitar" de que fala o art. 231 do Estatuto repressivo. É inequívoco que (...), com vontade dirigida à prática da ação incriminada, qual seja, a de promover ou facilitar a saída da vítima, tendo consciência de que iria ela entregar-se à prostituição no país a que se destinava, subministrou-lhe os meios materiais necessários a tanto e, mais, prestou-lhe auxílio oferecendo-lhe abrigo em Recife antes do embarque, conforme ela mesma confessou, além de ter indicado-lhe a casa de meretrício (...), cujo proprietário conhece (... ${ }^{71}$.

O que ressaiu dos dados analisados foi a noção de que, em parte considerável das decisões, o simples favorecimento ou a intermediação da migração para a prostituição, independente sequer do intuito de lucro, já eram utilizados como elementos cruciais para a caracterização e punição do crime de tráfico internacional de pessoas para fins de exploração sexual. Na mesma senda, foi interessante notar que a maioria acachapante das decisões que enquadravam as noções de auxílio à migração para prostituição e tráfico internacional de pessoas na mesma esfera semântica o fazia com amparo direto na lei, não se remetendo sequer à doutrina penal ou à jurisprudência pertinente.

Segundo Piscitelli (2008), as análises costumam considerar que tráfico de pessoas e contrabando de migrantes, este o auxílio remunerado à migração, são coisas distintas. Há, porém, casos reais que apresentam elementos de ambos ou a transformação de um para o outro.

Esse tipo de situação também chegou a ser identificado nas decisões, no campo da equiparação semântica entre auxílio à migração para a prostituição e tráfico de pessoas. Exemplo foi o caso de uma mulher que, não se adaptando às condições de trabalho encontradas no país de destino, retornou ao Brasil e passou, então, a ser ameaçada sob o argumento de que deveria emigrar novamente para pagar as dívidas contraídas em função da primeira viagem. A segunda viagem somente não ocorreu, no caso descrito, em função de a ofendida ter sofrido assalto a caminho do Aeroporto de Guarulhos e, neste incidente, ter perdido o dinheiro que custearia o transporte até o destino final ${ }^{72}$. Observei, entretanto, que a grande maioria dos casos subjacentes às decisões investigadas não trazia elementos que

\footnotetext{
71 Documento 25; Apêndice B.
}

72 Documento 16; Apêndice B. 
ilustrassem, com clareza, a transformação do auxílio gratuito ou do contrabando de migrantes em tráfico de internacional de pessoas.

Na categoria seguinte, exercício da prostituição como degradação moral, formulei a pergunta sobre em que ponto a prostituição é representada como fruto da degradação moral das vítimas, das pessoas acusadas, da família e da sociedade.

$\mathrm{O}$ que permeou o exame dessa categoria foi o desejo de mapear a presença de componentes moralizantes em cada uma das decisões, bem assim dos potenciais desdobramentos desses elementos nos atos de sentenciar e lavrar o acórdão penal condenatório ou absolutório.

Entre as falas mais sensíveis a esse marcador analítico destacou-se uma que se referia a "proposta de trabalho honesto", em clara referência dicotômica ao trabalho sexual ${ }^{73}$. Os trechos mais emblemáticos dessa categoria foram assim redigidos:

Além de possuir personalidade voltada à prática reiterada de violações a bens jurídicos tutelados pelas normas penais, as consequências do delito praticado pelo condenado (...) são as mais nefastas possíveis: sob sua condenação e ação, faz envolver práticas incompatíveis e inaceitáveis em pleno século 21, que não deixam de ser uma espécie de "escravidão", uma "escravidão sexual". As mulheres brasileiras são enviadas ao exterior, mais exatamente para Portugal, para entregar seus corpos com o escopo de pagarem as passagens aéreas e a estadia já adiantadas e, sobejando, trazendo algo de volta ao Brasil.

É um procedimento vil e desumano: valer-se da miséria, da pobreza e da pouca de [sic] oportunidade que esse país oferece a seus próprios nacionais - para bem viver e/ou subsistir com decência e dignidade, com o fito de ganhar mais, lucrar, enricar-se. E mais: para construir uma verdadeira organização criminosa, que ilude e degrada as mulheres nacionais.

Além disso, uma outra consequência, é o fato de se disseminar no estrangeiro uma ideia errônea e equivocada sobre a mulher brasileira, dando-lhe nuances pejorativas e vulgares - como se isso fosse a regra. Sem dizer que tal fato pode passar a impressão que o Estado brasileiro não atua, é conivente com tal conduta criminosa. As consequências, pois, são as piores possíveis. O estrangeiro, notadamente o português é bem vindo ao Brasil, até em face dos vínculos históricos e etc. No entanto, não se pode mais admitir que ao invés de vir para contribuir para o progresso e o desenvolvimento do país, aqui venha sangrar-lhe, depauperar-lhe, como se mercenário fosse. Não se pode mais aceitar esse tipo de comportamento, especialmente por quem vem de fora ${ }^{74}$.

\section{$* * *$}

Por via do tipo penal em apreço, visa-se proteger a moralidade pública sexual, os bons costumes e também a liberdade sexual, independentemente da discussão acerca do fato de outros países serem ou não mais liberais no tratamento da exploração do comércio sexual ${ }^{75}$.

73 Documento 9; Apêndice B.

74 Documento 5; Apêndice B.

75 Documento 11; Apêndice B. 
A conduta social [da ré] dá conta de ser pessoa de vida fácil e atividades opróbrias. Quanto à personalidade, revela severos transtornos, delineados pela dificuldade em se amoldar às regras do lucro moral e honesto ${ }^{76}$.

$* *$

Consideradas as circunstâncias judiciais acima valoradas, e acrescentando a torpeza do agir da recorrente (gana de obter vantagem econômica com a viagem e atividade degradante da vítima), o que dá margem ao reconhecimento da agravante do art. 61, II, “a”, do CP (...) ${ }^{77}$.

A categoria pode fornecer interessantes subsídios de uma releitura do discurso judicial, como instância de reafirmação da moral social dominante, que condena a mulher que se prostitui, em julgamento a priori.

A projeção do exercício da prostituição como degradação moral, como visto acima, fala de ilusão e degradação das mulheres nacionais. Aborda, também, o tema da difusão, no estrangeiro, de uma imagem pejorativa e vulgar da mulher brasileira. Reafirma, por fim, a lei penal que defende a moral pública social dominante. Reforça, por todo o exposto, estereótipos que militam em favor da reprodução de assimetrias nas relações de gênero.

A penúltima categoria analítica da pesquisa é a da mulher cisgênero migrante como vítima. Assim como na categoria anterior, a forma como a pessoa que se prostitui é retratada nas decisões tem importância para a identificação de bandeiras morais e culturais levadas dentro do discurso repressivo penal do tráfico de mulheres cisgênero para o mercado do sexo, cujo teor almejei compreender com maior precisão.

Essa categoria também permite explorar o espaço de fala da mulher supostamente traficada, a sua voz, ou ausência dela, dentro do processo judicial, e se lhe é atribuído, de um lado, o papel de vítima ou, de outro, o de dona da própria vontade e responsável pela sua sorte.

Tem ainda o potencial de favorecer o estudo de como a mulher que se prostitui é caracterizada na jurisprudência e qual é a mensagem que se difunde com as características atribuídas à mulher brasileira que migra pelas mais diversas razões e com os mais variados projetos de vida.

Constatei que, em cerca de $60 \%$ de todas as decisões, a mulher supostamente ofendida, independentemente de suas características pessoais ou do contexto laboral e social que

\footnotetext{
76 Documento 25; Apêndice B.

77 Documento 35; Apêndice B.
} 
vivesse no Brasil, foi retratada como vítima do tráfico de pessoas ${ }^{78}$. A percepção da imagem da vítima foi mensurada pela intensidade do uso do vocábulo ao longo das decisões. Intrigante, sem embargo, foi verificar que, em parte dos documentos analisados, o comportamento da vítima foi utilizado como móvel da redução da pena-base do crime, essencialmente nos casos em que já se prostituísse no Brasil ou anuísse com a proposta de migrar para o exercício da prostituição. Indico trechos bastante elucidativos disso:

A vítima contribuiu com a conduta praticada pela ré, pois vislumbrava ir para o exterior e lá se prostituir e "ganhar um bom dinheiro" (grifos no original) ${ }^{79}$.

$* * *$

As consequências extrapenais não foram graves e o comportamento das vítimas facilitou a ação do agente, já que anuíram no transporte a esta Capital, para posterior deslocamento para a Europa (grifos no original) ${ }^{80}$.

$* * *$

O comportamento da vítima de certa forma colaborou para a prática do crime, na medida em que ela já se prostituía nesta cidade e decidiu ir para a Europa com o fim de prostituir-se, somente não sabia que seria mantida em cárcere privado, achando que teria opção de aceitar ou rejeitar programas. Essa circunstância deve ser levada em favor do réu ${ }^{81}$.

O discurso das decisões poderia ser sintetizado, por esse viés, na ideia de que a mulher que aceita se prostituir, no Brasil ou no exterior, assume um risco que favorece todas as engrenagens do tráfico de pessoas para fins de exploração sexual, incorrendo em comportamento que, pela sua reprovabilidade latente, deve ser deduzido do grau de apenação dos agentes do delito.

Mais de $20 \%$ dos documentos em que houve condenação não faziam alusão a fraude, lucro, coação, situação de vulnerabilidade ${ }^{82}$. Nessas mesmas situações, o interessante é observar que metade sequer transcrevia a fala da vítima como praxe para a fundamentação. A outra metade, mesmo transcrevendo, ignorou a subjetividade emergente das vozes ali presentes e teve o amparo da letra seca da lei para isso.

Causa estranheza pensar, nesse particular, que, não sendo considerados em primeiro plano elementos relacionados à violência, fraude, engano e exploração, o simples fato de exercer a prostituição no país e pretender, eventualmente, prosseguir na atividade no exterior,

\footnotetext{
78 Documentos em que a mulher migrante é retratada como vítima: 2, 4, 6, 7, 8, 9, 10, 11, 12, 13, 14, 16, 18, 20, 21, 22, 24, 25, 26, 27, 28 e 36; Apêndice B.

79 Documento 18; Apêndice B.

80 Documento 2; Apêndice B.

81 Documento 12; Apêndice B.

${ }^{82}$ Documentos 1, 2, 6, 7, 13, 22, 34 e 36; Apêndice B.
} 
possa ser móvel da discriminação das garotas que já se prostituíam e foram traficadas em relação àquelas que saíram do Brasil com promessa de estudos ou de trabalho em outra área.

É o discurso judicial produzindo a seguinte mensagem: a submissão a condições degradantes e o ultraje à dignidade da mulher cis que se prostitui têm reduzida importância para o sistema penal repressivo do tráfico internacional de pessoas, pois a prostituta tem seus direitos limitados a um padrão de subalternidade.

Pelos dados colhidos, a associação entre os termos vítima e prostituta - ou seus equivalentes, como garota de programa e meretriz -, quando ocorrente, fez notar que, mesmo nas hipóteses em que se procedeu ao suposto acolhimento da prostituta por utilização do sistema penal repressivo, a resposta do Judiciário veio mitigada, estimulando, na outra ponta do discurso, o aliciamento para a prostituição no exterior dentro desse segmento de mulheres cis, independentemente de também estarem em causa elementos como a venda de falsos sonhos e a violência em todas as suas formas.

Quanto ao lugar de fala das mulheres cisgênero em nome das quais ativou-se o aparato persecutório do Estado para repressão da conduta prevista no Artigo 231 do Código Penal Brasileiro, pude observar que mais da metade continha transcrição ou registro indireto da narrativa das supostas vítimas ${ }^{83}$.

Por outro lado, surpreendeu perceber que a concessão de lugar de fala nos processos para essas pessoas não se configurou como indício de abertura do Poder Judiciário à subjetividade que emanava dos depoimentos, especialmente no que concerne aos elementos da fraude, coação, violência, engano, ameaça, etc., todos contidos no Protocolo de Palermo (NAÇÕES UNIDAS, 2003).

A transcrição dos depoimentos, em oposição às expectativas alimentadas no início do projeto de pesquisa, teve a finalidade instrumental de preencher o relatório essencial que acompanha as sentenças e os acórdãos em apelação criminal. Após, foi o conteúdo dessas vozes desconsiderado ou citado superficialmente para fins de capitulação penal dos fatos, na generalidade dos casos, quando não para reduzir a pena-base do crime, na forma do Artigo 59 do Código Penal Brasileiro ${ }^{84}$, como anteriormente demonstrado.

83 A narrativa das ofendidas está presente nos Documentos 1, 2, 4, 5, 6, 7, 9, 13, 14, 16, 17, 18, 19, 20, 21, 25, 27, 28, 29 e 35; Apêndice B.

84 “Art. 59 - O juiz, atendendo à culpabilidade, aos antecedentes, à conduta social, à personalidade do agente, aos motivos, às circunstâncias e consequências do crime, bem como ao comportamento da vítima, estabelecerá, conforme seja necessário e suficiente para reprovação e prevenção do crime: I - as penas aplicáveis dentre as cominadas; II - a quantidade de pena aplicável, dentro dos limites previstos; III - o regime 
Essa pretensa objetivação das decisões esteve muito presente no corpus de análise, excepcionada de forma mais clara em apenas três curtos trechos de diferentes decisões, que lançaram luzes sobre o papel da narrativa das vítimas na investigação do tráfico internacional de pessoas para fins de exploração sexual. Colhe-se desses excertos isolados:

Crime consumado. Materialidade e autoria comprovadas, sobretudo, com base nos depoimentos das duas vítimas, que esclarecem acerca da atuação da ré nas negociações juntamente com o espanhol, levando-as, inclusive, à polícia federal para tirar passaportes, e de sua estada na Espanha ${ }^{85}$.

$* * *$

As declarações da vítima neste tipo de delito possuem valor probante fundamental, vez que são fonte direta de informação de como os fatos ocorreram ${ }^{86}$.

\section{$* * *$}

Em crimes da espécie, praticados, no mais das vezes, na clandestinidade, deve ser deferida especial atenção para a narrativa da vítima, mormente quando coerente com as demais circunstâncias em que cometido o delito. Assim, assume ela caráter preponderante como prova, autorizando, aqui, que se reconheça o concurso formal, pois tudo nestes autos leva a crer que, efetivamente, foram encaminhadas outras três mulheres para a Europa, sempre com o auxílio de (...). Enfatizo que o único interesse da lesada é apontar os verdadeiros culpados e narrar sua atuação, e não acusar inocentes. O depoimento de (...) harmônico, estável e seguro desde a fase inquisitória, é prova quantum satis de que a ré teve também participação ativa na emigração de (...), pelo que deve incidir a causa especial de aumento contida no art. 70 , caput, do Código Penal ${ }^{87}$.

Última categoria analítica da pesquisa, a noção de migração para a prostituição como ingenuidade ou vulnerabilidade foi localizada em 6 das 36 decisões ${ }^{88}$.

Essa categoria, assim como a anterior, tem aptidão para sinalizar elementos do discurso que se direcionam a formar um retrato da pessoa a quem se atribui o sofrimento de ter sido traficada para exploração sexual, o que sem dúvidas se expande do papel para o mundo da vida e influencia o imaginário social sobre o perfil das mulheres brasileiras que migram.

Em apenas duas das situações descritas, não houve narrativa de tráfico subjetivamente compatível com os parâmetros do Protocolo de Palermo (Nações Unidas, 2003), casos em que, mesmo assim, as ofendidas foram retratadas como "garotas iludidas" 89 ou "pessoas humildes e de pouca instrução, apresentando assim, alto grau de vulnerabilidade em caso de

inicial de cumprimento da pena privativa de liberdade; IV - a substituição da pena privativa da liberdade aplicada, por outra espécie de pena, se cabível".

85 Documento 16; Apêndice B.

86 Documento 26; Apêndice B.

87 Documento 25; Apêndice B.

${ }^{88}$ Documentos 2, 12, 18, 20, 21 e 28; Apêndice B.

89 Documento 2; Apêndice B. 
persuasão e mesmo de intimidação" ${ }^{90}$. Nos demais casos, todos conducentes à condenação das pessoas acusadas, a caracterização judicial do perfil das mulheres cis traficadas foi talhada consoante segue:

No caso sub examine, verifica-se que o grau de reprovação da conduta do réu é intenso, haja vista que se aproveitava de pessoas por quem se dizia apaixonado, para levá-las consigo ao exterior com fins de prostituição, bem como solicitavalhes ajuda para conseguir levar ainda outras pessoas de seu conhecimento, além do que tinha especial predileção pelas garotas de Natal, Recife e Fortaleza, por serem pobres (portanto mais vulneráveis) e bonitas (portanto capazes de atrair mais clientes).

(...)

No que concerne às circunstâncias do delito, já foram acima ponderadas, considerando que ele se aproveitava de pessoas mais vulneráveis para convencê$\operatorname{las}^{91}$.

$* * *$

A ré, de forma livre e consciente, tentou facilitar a saída do país da vítima D. para que esta se prostituísse na cidade de Zaragoza/Espanha, sendo-lhe exigível conduta diversa. Foi motivada pela possibilidade de que sua prima ingressasse na prostituição no exterior, a fim de obter lucro fácil. Não há registro de antecedentes criminais. Personalidade dentro dos padrões normais. De conduta social em desacordo com os bons costumes. Circunstâncias normais à espécie. As consequências são desabonadoras, eis que aliciou a vítima nas suas relações de parentesco (prima), pessoa jovem (24 anos), sem qualificação profissional (faxineira), à procura de uma segurança financeira e pessoal (grifos acrescidos) ${ }^{92}$.

$* * *$

(...) $\mathrm{O}$ fato de as moças terem conhecimento de que trabalhariam como prostitutas não afasta a tipicidade da conduta imputada à ré.

É que o tipo penal previsto no art. 231 do CPB tem por finalidade evitar o tráfico de mulheres, sobretudo quando efetuado por terceiros que visam lucrar às custas de pessoas menos providas elou esclarecidas (grifos acrescidos) ${ }^{93}$.

$* * *$

Cremos que o passo inicial é perceber a verdadeira situação das mulheres envolvidas, ou seja, as perceber como vítimas da miséria, da ganância, da nossa própria cultura, das esperanças desfeitas e dos sonhos nunca realizados, exploradas em suas ilusões de uma vida melhor e vilipendiadas no corpo e espírito, destroçadas em sua dignidade e auto-estima [sic], no que pese tentarem demonstrar, muitas vezes, com uma desfaçatez histriônica, um certo alheamento dos fatos, convencidas de (...) estarem realizando atividades conscientes e com vontade livre. Verifica-se que muitas das mulheres envolvidas romantizam suas situações, ainda acreditando que, um dia, "sairão desta vida" e se casarão com um "gringo" rico e carinhoso, com quem formarão família respeitável em um vínculo

90 Documento 36; Apêndice B.

91 Documento 12; Apêndice B.

92 Documento 18; Apêndice B.

93 Documento 20; Apêndice B. 
amoroso estável e duradouro, em uma evidente manifestação de uma adolescência latente, cuja vivência integral não foi permitida pelo destino ${ }^{94}$.

Este último trecho é especialmente relevante sob o ponto de vista da imagem vitimadora que se projeta sobre as mulheres que migraram no intuito de se prostituírem, difundindo-se em três eixos. No primeiro eixo, estaria a face vulnerável de quem vem da pobreza e encontra uma barreira social praticamente intransponível para superar essa condição. O segundo eixo é o da infantilidade da mulher que migra para se prostituir. $\mathrm{O}$ último representa, por sua vez, a face gananciosa, da desfaçatez e da trapaça para ascensão social daquela mulher que, marginalizada pela pobreza, interessa-se pela ideia de trilhar um projeto de vida fora da dogmática andro-cis-heteronormativa.

Com isso, forma-se, à maneira de Picasso, uma imagem cubista da mulher cisgênero migrante, em especial daquela que está disposta a ingressar na prostituição. Concentram-se, na mesma figura romantizada e degradada, um conjunto de atributos que parecem não se encaixar e que reforçam não apenas a impossibilidade de que a mulher possa, por uma escolha racional, no contexto das opressões de gênero, raça, cor e classe em que vive, buscar na prostituição um meio legítimo de tentar escapar à circularidade do modelo excludente em que está enredada.

O projeto de mercantilização do uso do corpo é rejeitado como opção e, nesses termos, condenado, aprioristicamente, pelo Estado, ali representado pela pessoa de um magistrado que, muito provavelmente, não vivenciou as mesmas contingências de vida daquelas jovens que reputa tolas e ambiciosas, em seu discurso estereotipado.

De posse do arcabouço de conteúdo que a análise propiciou, chega o momento de refletir sobre como as tramas discursivas identificadas incidem sobre o papel de gênero atribuído, pela Justiça Penal Brasileira, à mulher cisgênero que migra, ou tenta migrar, ao exterior.

94 Documento 28; Apêndice B. 


\title{
3 TRÁFICO INTERNACIONAL DE MULHERES: MIGRAÇÃO, SEXUALIDADE E DISCURSO JURÍDICO-PENAL. POR UMA NOVA LINGUAGEM DE PROTEÇÃO DO FEMININO NA SOCIEDADE PÓS- COLONIAL
}

\author{
Hombres necios que acusáis \\ a la mujer sin razón, \\ sin ver que sois la ocasión \\ de lo mismo que culpáis: \\ si con ansia sin igual \\ solicitáis su desdén, \\ ¿por qué queréis que obren bien \\ si las incitáis al mal?
}

(Sóror Juana Inés de la Cruz, Satíricas a la vanidad masculina)

\subsection{O cenário brasileiro do tráfico de mulheres cis: uma realidade ainda pouco conhecida}

O recorte das sentenças e dos acórdãos coletados na base de dados do UNODC nos casos de tráfico de pessoas relativos à prostituição e à exploração sexual teve em vista, primeiramente, o fato de que esses são os campos em que as estatísticas globais do próprio UNODC lançam alertas mais gritantes.

Ainda no ano de 2008, produzi, em coautoria com Samira Lana Seabra, artigo sobre tráfico de pessoas na perspectiva de gênero (LIMA e SEABRA, 2011).

O parâmetro que se apresentava a quem pretendia enfrentar o tema era, fundamentalmente, o do UNODC do ano de 2006. Afirmava-se que cerca de 54\% das vítimas no mundo todo eram mulheres e que o comércio de pessoas promovia a circulação de verbas ilícitas de cerca de 7 a 9 bilhões de dólares anuais (LIMA e SEABRA, 2011). Em 2008, o UNODC já estimava que o tráfico internacional de pessoas movimentava, anualmente, até US\$ 12 bilhões (doze bilhões de dólares). Atestava, ainda, que o perfil das pessoas vitimadas era de pobreza, isolamento e fraqueza (NAÇÕES UNIDAS, 2008) ${ }^{95}$.

95 A publicação em referência foi produto da conferência global ocorrida em Viena, entre 13 e 15 de fevereiro de 2008. 
Em 2009, foi divulgado um segundo relatório global com dados acerca de 155 Estados e territórios. Comemorava-se que, enquanto, em 2003, apenas um terço dos Estados-membros possuía legislação contra o tráfico de pessoas, ao final de 2008, quatro quintos já tinham promovido mudanças legislativas, sendo que mais da metade dos Estados-membros tinha desenvolvido planos nacionais para enfrentar o problema (NAÇÕES UNIDAS, 2009).

Dizia-se que alguns palpites poderiam ser lançados acerca do perfil das vítimas identificadas no ano de 2006, muito embora já se soubesse que havia marcas de influência das leis e prioridades locais nesses dados, a enfocarem, comumente, a questão da exploração de crianças e adolescentes e o tema da exploração sexual. Os resultados foram que mulheres correspondiam a $66 \%$ das vítimas, crianças e adolescentes do sexo feminino, a 13\%, homens, a $12 \%$ e meninos e garotos, a $9 \%$. A exploração sexual, especificada por 52 dos 61 países notificadores, marcou 79\% dos casos apreciados (NAÇÕES UNIDAS, 2009).

Sucederam-se os relatórios globais de 2012 e 2014. Continuaram alardeando a gravidade e as amplas dimensões do tráfico de pessoas, na linha dos primeiros, com amparo nos dados que eram remetidos pelos países que aderiram ao Protocolo de Palermo (NAÇÕES UNIDAS, 2003).

O Relatório Global de 2012 (NAÇÕES UNIDAS, 2012) sintetizava, com relação ao período de 2007 a 2010, achados de acordo com os quais as mulheres giravam em torno de $55 \%$ a $60 \%$ do total de pessoas traficadas no mundo. Quando agregadas crianças e adolescentes, a população feminina traficada girava em torno de $75 \%$ do total. Houve, porém, um destaque quanto ao tráfico para trabalhos forçados, que passou a corresponder a uma parcela maior dos casos identificados, o que pode ser atribuído à abertura do enfoque das políticas de enfrentamento ao tráfico conduzidas pelos Estados-membros da Convenção das Nações Unidas Contra Drogas e Crime ${ }^{96}$.

Especificamente com relação à América, tomada como uma das quatro macrorregiões do globo, o total das vítimas de que se disse ter notícias, com base em 15 países, distribuídos na América do Norte, América Central/Caribe e América do Sul, girou ao redor de seis a sete mil pessoas, das quais $51 \%$ para exploração sexual e $44 \%$ para trabalhos forçados. O número de vítimas registradas permaneceu, assim, bem distante do contingente de milhares de pessoas que era alardeado desde o Relatório Global do ano de 2006. A justificativa para essa potencial

${ }^{96}$ Segundo o documento, o tráfico para fins de exploração sexual corresponderia a $58 \%$ de todos os casos de tráfico mundialmente detectados ( $21 \%$ a menos que em 2006), ao passo que o tráfico para trabalhos forçados corresponderia a $36 \%$. 
incongruência residia, fundamentalmente, em entraves como a subnotificação e dificuldades de mobilizar de forma integrada os Estados-Partes a atuarem em face do problema.

O Relatório Global de 2014 (NAÇÕES UNIDAS, 2014), a versar sobre o período de 2010-2012 (mas que também contém alguns dados de 2013), não trouxe grandes novidades com relação à identificação global das vítimas pelo gênero ${ }^{97}$. Apresentou o perfil mundial das vítimas do tráfico como sendo, outra vez, predominantemente feminino $(71 \%)^{98}$.

Na América do Sul, prevaleceu, entre 2010 e 2012, a exploração sexual, a girar em torno de $54 \%$, enquanto o trabalho forçado ficaria na casa dos $41 \%$, a totalizarem $95 \%$ das notícias de tráfico de pessoas recebidas. Outras formas de exploração identificáveis como tráfico, com esteio no Protocolo de Palermo (NAÇÕES UNIDAS, 2003), não tiveram participação expressiva nos números, levantando pressupostos que poderiam girar em três direções investigativas: (i) possibilidade de que fossem violências menos comuns no Cone Sul; (ii) maior dificuldade de sua identificação ou; (iii) características das políticas de enfrentamento ao tráfico locais, possivelmente centradas predominantemente na exploração sexual e laboral. Entre a inexistência e a invisibilidade, houve dentro desse espectro de casos remanescentes a apresentação de um espaço relevante para futuras pesquisas.

No campo da exploração sexual, atestou o relatório que 95\% das vítimas indicadas era do gênero feminino. Foi igualmente afirmada a proeminência do tráfico doméstico e intrarregional, já que o tráfico para fora da América do Sul se estabilizara no patamar de apenas $6 \%$.

No que tange ao tráfico entre diferentes regiões do globo, o relatório que condensou dados de 2007 a 2010 (NAÇÕES UNIDAS, 2012) apontou que as vítimas provenientes do Brasil eram particularmente proeminentes na Espanha, mas também haviam sido detectadas em outros 11 países da Europa Ocidental e Central, bem como no Estado de Israel. Esse nível de detalhamento inexiste no relatório de 2011 em diante (NAÇÕES UNIDAS, 2014), que se limita a assentar que os maiores fluxos traçados pelas vítimas do tráfico de pessoas da

97 Concluiu que $49 \%$ das vítimas eram mulheres e que, dos $33 \%$ de vítimas crianças e adolescentes, dois terços eram meninas ou garotas.

98 Com relação à distribuição percentual das formas de tráfico encontradas nesse mesmo período, o relatório de 2014 fez consignar que, dividindo-se o globo em (i) África/Oriente Médio, (ii) América, (iii) Europa/Ásia Central e (iv) Ásia Leste/Sul da Ásia/Pacífico, os percentuais das formas de exploração por tráfico eram sensivelmente mais representativos quando se tratava da exploração sexual, com índices variantes entre 48 e $66 \%$, sendo na América o menor deles. Em segundo lugar, ficou, novamente, o tráfico para trabalhos forçados, a girar em torno de 26 a 47\%. A exceção à estatística média foi no Leste e Sul da Ásia e na Região do Pacífico, onde a maioria dos casos detectados se referiam a trabalhos forçados (64\%), figurando a exploração sexual em segundo lugar (26\%). Os percentuais referentes a outras formas de exploração giraram em torno de 4 a 10\% em todas as regiões do globo, sendo na América o registro do menor índice. 
América do Sul seguem em direção à Europa Ocidental e Central, América do Norte e Central, além do Caribe.

Diante de todos esses dados, impossível subestimar o fato de que o tráfico de pessoas está fortemente associado a gênero. Embora flutuem percentualmente, referidas estatísticas são comumente utilizadas para alimentar a hipótese de que meninas e mulheres são o principal público a ser atingido pelas políticas de enfrentamento ao tráfico de pessoas.

Cabe, entretanto, dar um passo atrás e perguntar: será que essas estatísticas revelam a magnitude e o perfil do problema no contexto brasileiro? Há possibilidade de que tais estatísticas sobrerrepresentem, subrepresentem ou sejam opacas à realidade brasileira? Mais: a invisibilização de transgêneros nos relatórios globais tem impacto na discursividade do tráfico de pessoas e influi nos saberes que informam esse campo investigativo? Por essa perspectiva, os relatórios citados, mais que elucidarem, suscitam dúvidas ${ }^{99}$.

No Relatório Nacional sobre Tráfico de Pessoas referente ao período de 2005 a 2011 (BRASIL, 2012), a imprecisão das estimativas sobre o cenário brasileiro do tráfico de pessoas foi declarada. As dificuldades para calcular quantas pessoas brasileiras são submetidas a tráfico em termos anuais, mensais e diários foram atribuídas a fatores como (i) a subnotificação do crime, (ii) a ausência de legislação penal adequada, para abranger o tráfico de pessoas para fins que não o da exploração sexual, (iii) a falta de conhecimento de profissionais que recebem demandas em reconhecer as vítimas e (iv) a pendência de ajuste e uniformização dos sistemas de informação das instituições responsáveis, que não gravam as características dos envolvidos no impasse nem contemplam variáveis essenciais para a compreensão do fenômeno.

Ficou evidenciado, naquele relatório nacional, que a diferença entre tráfico de pessoas e migração irregular não é clara para todas as instituições do território nacional. O exemplo foi colhido do relatório produzido pela Comissão Parlamentar de Inquérito do Senado Federal em 2011, segundo o qual o aliciamento para emigração ou o aliciamento internacional configuram, por si, tráfico de pessoas (BRASIL, 2012). Esse mesmo exemplo poderia contemplar, pela leitura dos relatórios, também os sistemas de Segurança Pública e Justiça

99 Castilho (2015) evidencia a impossibilidade de comparação real da evolução do quadro mundial acerca do tráfico de pessoas com amparo nos Relatórios Globais produzidos nos anos de 2012 e 2014 pelo UNODC. A comprometerem esse mapeamento do real, em primeiro lugar, encontra-se a dificuldade que reside na indefinição conceitual do que vem a ser exploração sexual. Em segundo, a ausência de um padrão normativo comum de notificação do que vem a ser tráfico de pessoas entre os Estados-Partes. Com isso, o comparativo entre uns e outros, bem assim a contabilização global de número de vítimas, o mapeamento de rotas e as estimativas da movimentação de capital que o tráfico de pessoas proporciona ficaram comprometidos. 
Criminal, que parecem se guiar pelos parâmetros de tipicidade penal extraídos dos Artigos 231 e 231-A do Código Penal Brasileiro e reduzir o fenômeno à exploração sexual, quando não registram como tráfico de pessoas a simples migração, interna ou internacional, de pessoas adultas para exercício voluntário da prostituição.

Dentro do discurso repressivo-penal, o que se nota, com base nos relatórios nacionais, é a dissonância, de um lado, da Polícia, do Poder Judiciário e do Ministério Público e, do outro, de órgãos como a Secretaria de Inspeção do Trabalho do Ministério do Trabalho e Emprego (MTE/SIT). Enquanto esta última caracteriza trabalhadores resgatados em condição análoga à da escravidão como vítimas da figura do Artigo 149 do Código Penal ${ }^{100}$, os primeiros se limitam a identificar a questão do tráfico na figura da exploração sexual. Não aleatoriamente, identificou-se, no Relatório referente a 2005-2011 (BRASIL, 2012), que o número de processos distribuídos entre os tribunais brasileiros em decorrência do resgate de trabalhadoras em condição análoga à de escravo corresponde a quase mil, enquanto os de tráfico de pessoas, interno e internacional é de apenas $20 \%$ desse total.

Nesse quadro, deixa de haver a preocupação com o fato de que trabalhadoras resgatadas em condição análoga à de escravidão sejam consideradas vítimas de tráfico de pessoas, o que poderia favorecer o reconhecimento de direitos trabalhistas de nacionais no exterior e a regularização da permanência de estrangeiras e estrangeiros no país.

Tampouco há dupla identificação de diferentes formas de exploração sexual como casos que se enquadram tanto na lógica do tráfico de pessoas quanto como trabalhos forçados. Senão pelo prisma da correta tipificação penal, o cuidado com o duplo registro favoreceria um mapeamento mais consistente de ambos os fenômenos no território brasileiro, podendo ser útil no direcionamento de recursos e na elaboração de políticas públicas adequadas.

O que temos hoje como dado alarmante é que, particularmente quanto à forma de sistematização e operacionalização de demandas por parte da Polícia, do Poder Judiciário e do Ministério Público, não se tem em vista a aplicação de parâmetros normativos mais amplos que o tipo penal de tráfico de pessoas. Ignora-se, em parte, o Artigo 2oo $§ 4^{\circ}$, da Política Nacional de Enfrentamento ao Tráfico de Pessoas, segundo o qual "a intermediação, promoção ou facilitação do recrutamento, do transporte, do alojamento ou do acolhimento de

\footnotetext{
${ }^{100}$ Código Penal Brasileiro, Artigo 149: "Reduzir alguém a condição análoga à de escravo, quer submetendo-o a trabalhos forçados ou a jornada exaustiva, quer sujeitando-o a condições degradantes de trabalho, quer restringindo, por qualquer meio, sua locomoção em razão de dívida contraída com o empregador ou preposto: (...)".
} 
pessoas para fins de exploração também configura tráfico de pessoas" ${ }^{101}$. Com isso, a margem de subnotificação do problema se torna ainda maior, não havendo espaço para a produção de pesquisas quantitativas confiáveis.

Essas mesmas dificuldades permaneceram latentes no texto do Relatório Nacional referente ao ano de 2012 (BRASIL, 2014), elaborado em meio à tentativa de implementação de uma metodologia de coleta integrada de dados sobre tráfico de pessoas em diferentes instâncias de controle público ${ }^{102}$.

O pouco que se conhece do perfil das vítimas foi apresentado por dados recolhidos pela Coordenação-Geral da Vigilância de Agravos e Doenças não Transmissíveis do Ministério da Saúde (MS/SVS/CGDANT), lançados no Sistema de Informação de Agravos de Notificação (SINAN) — ainda em fase de expansão entre os municípios —, e do Censo dos Centros de Referência Especializados em Assistência Social (CREAS), do Ministério do Desenvolvimento Social ${ }^{103}$. Também a Secretaria de Políticas para Mulheres efetuou registros mais pormenorizados sobre as vítimas (BRASIL, 2014).

Ocorre que o sistema de saúde somente é capaz de captar demandas de tráfico de pessoas em que as pessoas ofendidas requerem cuidados médicos. Igualmente limitado, o CREAS traduz o perfil apenas de quem acessa o serviço em busca de apoio, não funcionando como parâmetro de universalização nacional. Por fim, o Disque 180, da Secretaria de Políticas para Mulheres, permite calcular o número de relatos de tráfico de pessoas e o perfil de quem acessa o serviço, mas não é preciso sobre o perfil da mulher traficada e não alcança a população sem acesso nem especifica se as vítimas são crianças ou adolescentes, adultas, cis ou trans (BRASIL, 2014).

Com todas essas dificuldades, a síntese alcançada pelos serviços de saúde no período de 2010 a 2011 era de que as vítimas de tráfico de pessoas eram, majoritariamente, do gênero feminino ${ }^{104}$. No ano de 2012, examinado mais recentemente, as mulheres apareceram em $80 \%$ dos casos (BRASIL, 2014).

\footnotetext{
${ }^{101}$ Anexa ao Decreto no -5.948 , de 26 de outubro de 2006.

102 Pretende-se, nos próximos anos, que sejam coletadas pelos atores estratégicos informações sobre a vítima, o traficante, a experiência do tráfico, os procedimentos dos órgãos de Segurança Pública e Justiça Criminal e os crimes correlatos.

${ }^{103}$ Este último, porém, limita-se a registrar as características da vítima para o mês de referência, o que dá uma imagem da realidade apenas por amostragem.

${ }^{104}$ Foram 39 das 52 vítimas de 2010 e, 65 das 80 de 2011. A faixa etária mais recorrente se situou entre 10 e 29 anos, com predominância entre 10 e 19 anos, para ambos os sexos. Pessoas solteiras, de baixa escolaridade o que pode ser associado à idade — e residentes da área urbana (BRASIL, 2012).
} 
O estudo referente ao ano de 2012 trouxe novos elementos, colhidos dos formulários preenchidos pelo sistema de saúde com relação à categoria raça/cor, na interface com o gênero. $59 \%$ das mulheres eram negras ou pardas e $40 \%$ brancas. O perfil dos homens, de outra parte, era de $63 \%$ entre negros e pardos e $33 \%$, de brancos. A porcentagem de pessoas negras e pardas identificadas como vítimas superou a média de sua participação na população brasileira, que é de 51\% (BRASIL, 2014).

O CREAS, de sua parte, gravou, entre 2010 e 2011, maior número de vítimas que o sistema de saúde, num total de 121 atendimentos no ano de 2010 e, no mês de agosto de 2011 (mês de referência no ano), 236 casos. 148 destes eram de mulheres, 88 de homens. 137 vítimas tinham idade entre 18 e 59 anos. O relatório, entretanto, não fornece identificação de quantos e quais desses casos se referiam a tráfico interno e internacional de pessoas (BRASIL, 2014).

Os relatórios nacionais, assim como os globais do UNODC ocultam, primeiramente, as cifras trans. Além disso, dão alguma referência sobre o perfil de gênero e cor da população vitimada por tráfico de pessoas apenas no que se refere àquelas que recorrem ao sistema público de saúde ou assistência social, majoritariamente. O Disque 180, da Secretaria de Políticas para as Mulheres, poderia colaborar para o alargamento das fontes de informação, mas ainda carece de aperfeiçoamento na parte de coleta de dados.

Diz-se que a parcela da população atendida, entre pessoas negras e pardas, é superior à média nacional em cerca de $10 \%$ tanto para mulheres quanto para homens (BRASIL, 2014). Sem embargo, esse resultado ainda não foi processado em face, por exemplo, do perfil da população que busca atendimento no Sistema Único de Saúde, dada a coexistência de um segmento complementar de seguros e planos de saúde.

Ignorar essa perspectiva maior de cotejo é, possivelmente, invisibilizar parte das pessoas que poderiam integrar as políticas de prevenção e atendimento conduzidas pelo governo brasileiro. Considerando esse quadro, como antever o número de vítimas ou pressupor a forma como efetivamente se estruturam as relações que antecedem a migração nacional e internacional? Afinal, é possível arriscar quem é a mulher brasileira que migra e em que medida ela é o alvo de exploração por organizações criminosas?

Os relatórios nacionais ainda anotam que a distinção entre as ocorrências de tráfico interno e internacional se dá, de forma mais consistente, dentro dos órgãos associados ao Sistema de Justiça Criminal. A Polícia tem por hábito centrar-se no número de ocorrências 
registradas, mas ainda não apresenta um quadro completo do número de vítimas por ocorrência nem traça o perfil dessas mesmas vítimas ou de seus ofensores.

Dentro do Ministério Público e do Poder Judiciário, desde 2012, o Conselho Nacional de Justiça e o Conselho Nacional do Ministério Público vêm envidando esforços para monitorar os procedimentos administrativos investigativos e os processos judiciais que apuram tráfico de pessoas, porém tampouco fornecem dados estruturados acerca do perfil das vítimas ou dos agentes do tráfico de pessoas.

Convém, então, perguntar: qual é o espaço e a prioridade que os órgãos do Sistema de Justiça Criminal conferem à caracterização da vítima quando se veem em face de um possível caso de tráfico de pessoas? É possível extrair das ocorrências, dos procedimentos administrativos e dos processos judiciais em curso nesses órgãos ou já findos dados consistentes ou relevantes, ainda que não estruturados, sobre vítimas ou ofensores? Há, aqui, um vasto campo investigativo que merece ser desbravado.

Quanto ao aspecto das condenações penais por tráfico de pessoas, o relatório nacional relativo ao ano de 2012 (BRASIL, 2014) aponta um funil no sistema de justiça, em que o número de ocorrências policiais se converte em um montante inferior de casos levados ao sistema de justiça criminal e, na mesma ordem, segue o número de sentenças condenatórias e a quantidade de pessoas cumprindo pena por tráfico de pessoas. De todo modo, anota-se que a tramitação dos processos tem sido regular, ao contrário do suscitado pelo UNODC em seu último relatório (NAÇÕES UNIDAS, 2014), no qual alega a insuficiência das medidas adotadas pelos Estados-Partes para combate e punição do crime.

Nesse contexto, parece impróprio atestar a ineficácia da persecução penal do tráfico de pessoas com base na dissonância entre o número de notificações de tráfico e o número de condenações propriamente ditas. Mais prudente seria refletir sobre os limites objetivos da persecução, atrelados às limitações do padrão penal consagrado nos Artigos 231 e 231-A do Código Penal Brasileiro $(\mathrm{CPB})$ e à prejudicada correlação estatística com outros crimes que poderiam se caracterizar como tráfico de pessoas, e muitas vezes não o são. Entre eles, casos de trabalho em condições análogas à escravidão ${ }^{105}$.

Nesse campo de incertezas e caminhos desconhecidos é que se desenvolvem as tramas discursivas do tráfico de pessoas, mais especificamente, do tráfico internacional de mulheres cisgênero.

${ }^{105}$ Artigo 149 do Código Penal Brasileiro. 
A partir da análise que realizei das decisões coletadas pelo UNODC, tenho por confirmada a hipótese de que quase a metade das decisões examinadas identifica, explicitamente, no auxílio à migração para a prostituição, o próprio tráfico de pessoas.

As discussões internacionais sobre o que vem a ser a exploração da prostituição de outrem e a exploração sexual estacionaram, há quinze anos, dentro de um padrão que se pretende neutro em relação à prostituição, mas que, efetivamente, permite deslocamentos velados na prática de controle e monitoramento internacional que se associam ao padrão de criminalização e supressão da migração para a prostituição.

O marco penal brasileiro ainda está um passo atrás nesse debate. Instrumentaliza, de forma ostensiva e flagrante, a Justiça no projeto de erradicação da migração para a prostituição. Alinha-se ao perfil abolicionista traçado, em 1949, na Convenção e no Protocolo Final para a Repressão do Tráfico de Pessoas e do Lenocínio. Marginaliza, invisibiliza e intensifica os regimes de precarização laboral a que se submete quem vive da prostituição por opção própria, considerados os limites, as amarras e as assimetrias dos projetos de vida viáveis dentro do segregacionismo produzido pelo modo de produção capitalista.

E qual é o papel do Judiciário brasileiro nesse contexto? O simples fato de existir, no Artigo 231 do Código Penal, uma capitulação objetiva do tráfico de pessoas para fins de exploração sexual que não considera a subjetividade das pessoas supostamente ofendidas pela conduta exime o Judiciário de se empenhar no projeto maior de ressignificação das bases do problema, para alcance de patamares mais elaborados de discussão?

O caminho orientado pelo Protocolo de Palermo (NAÇÕES UNIDAS, 2003) pede um retorno à subjetividade das pessoas traficadas. Atender a esse propósito é trabalhar pela consagração de um modelo de enfrentamento do problema que realmente enfoque as situações de violência no processo migratório. Também é uma forma de mitigar o paternalismo assimétrico nas relações de gênero que emerge das decisões proferidas pelo Judiciário nos casos de tráfico internacional de mulheres cis.

A visão globalizada da mulher migrante como uma identidade única e essencializada, como pessoa de vulnerabilidade intrínseca, iludida, mas também gananciosa reproduz estereótipos que estão longe de demonstrar o real, prejudicando o projeto de vida da mulher que migra, seja ela vítima de exploração ou não.

$\mathrm{Na}$ formatação atual das decisões analisadas, o Judiciário tem se colocado a serviço de um projeto antimigratório que não deveria estar na pauta institucional brasileira. A partir do 
momento em que redes de auxílio à migração internacional de mulheres são perseguidas, independentemente da utilização de fraude, coação, engano, exploração ou qualquer tipo de violência, o próprio processo migratório autônomo e livre das mulheres passa a deparar com mais uma barreira. Além disso, quando os casos de abusos são colocados no mesmo balaio dos demais, perde-se a noção do tamanho do problema a enfrentar, o que tem reflexos negativos na alocação de recursos e na montagem de estratégias que permitam proteger as migrantes de toda forma de degradação de sua dignidade e liberdade.

O estereótipo da mulher jovem, migrante, ambiciosa e vulnerável está presente nas decisões do Judiciário brasileiro observadas. Presume-se a vulnerabilidade, mas ocultam-se as vozes das vítimas no momento em que se suprimem ou ignoram as suas narrativas sobre o processo migratório.

Não em todos os casos a alcunha da inocência e do despreparo para decidir migrar esteve correlacionada à descrição de sofrimento, violência, abuso ou engodo. Não há dúvidas que a questão precisa de uma releitura, sob pena de continuidade da utilização acrítica das lentes imperialistas, colonialistas e segregacionistas dos países ricos para resolução dos problemas brasileiros.

Nas decisões analisadas, há associação entre prostituição e exploração sexual como sinônimos ou espécie e gênero, correlação que milita em favor de um projeto abolicionista da prostituição. Este jogo de relações discursivas cunha na essência da profissão o estigma da violência e da desonra, reproduzindo uma ideologia que coloca em patamar de subalternidade a mulher cisgênero que ingressa na prostituição por vontade própria, no exercício de uma escolha racional dentro das possibilidades de ascensão profissional e econômica de que dispõe.

Os excertos das decisões analisadas que tratavam a prostituição como degradação moral não foram todos alheios ao sofrimento que o tráfico de pessoas pode causar às mulheres cisgênero que tentam emigrar. A dificuldade, sem embargo, residia na reafirmação da moralidade pública e dos bons costumes, mesmo após a modificação do Código Penal, que se referia a crimes contra os costumes e passou a reportar-se a essas figuras como crimes contra a liberdade sexual.

Ora, se o objetivo das figuras penais relacionadas à prostituição e à migração é, atualmente, proteger a liberdade sexual, parece-me incongruente punir, independentemente da análise da subjetividade das vítimas, o auxílio à migração como tráfico de pessoas, por 
ausência de lesividade ao bem jurídico tutelado: a liberdade quanto ao exercício da própria sexualidade, ainda que pela mercantilização do uso do corpo.

Decerto que a doutrina teve seu papel na reafirmação da prostituição como violência no cenário migratório, pois veio em amparo à fundamentação dos julgadores, especialmente na parte em que afirmava a irrelevância do consentimento para a configuração do tráfico, independentemente de investigação complementar da ocorrência de fraude, engano ou violência nos processos examinados.

A autoridade das lições de doutrinadores do direito penal como Magalhães Noronha, Mirabete, Damásio de Jesus, Fernando Capez, Luiz Regis Prado, Bento de Faria e Paulo José da Costa Jr. emergiu como escudo e base discursiva legitimadora para os magistrados de primeira e segunda instâncias ${ }^{106}$. Exemplo desse emparelhamento entre os dizeres da doutrina e o conteúdo estigmatizador da mulher migrante e da prostituição nas decisões observadas é o da sentença no Processo 89.00.4.0455-5. Colhe-se do documento:

Também no que diz respeito à consumação do crime, basta que elas [as mulheres migrantes] tenham sido ajudadas a sair do país como fim de que se prostituíssem, não importando apurar se a prostituição efetivamente ocorreu. De acordo com PAULO JOSÉ DA COSTA JR., o crime em questão refere-se "à conduta daqueles que vão recrutar mulheres destinadas à prostituição, em outros países. Costumam os mercadores de mulheres, para arregimentá-las, fazer uso de expedientes os mais variados, onde a astúcia e a malícia assumem tonalidade predominante: o embuste, o engodo, que passa por todas as gamas das promessas sedutoras e envolventes, até atingir a do casamento. ( ) Como se depreende, parte da conduta delituosa se desenvolve no Brasil, parte no estrangeiro. Mesmo assim, o crime será considerado como praticado no Brasil, por determinação do art. 6o do Código, que adota o princípio da ubiquidade nos crimes praticados à distância." (Comentários ao Código Penal - Parte Especial, vol. 3, Editora Saraiva, 1989)

Bento de faria também tratou deste crime. Ao comentar o art. 231 do nosso Código, afirmou: "O - tráfico de mulheres - também denominado, aliás impropriamente, de - tráfico de brancas -, desde que também é compreensivo das amarelas ou das negras, consiste no recrutamento de mulheres no estrangeiro, promovendo ou facilitando a sua entrada no país, a fim de aqui exercerem a prostituição, ou a saída das que aqui se encontram para que a pratiquem em outros países. ( ) Esse - tráfico - existe para significar um - comércio - ignóbil no qual a mulher é considerada mercadoria. ( ) ... mulheres ou raparigas, em regra menores, são atraídas por promessas de colocações vantajosas, arrastadas para longe da família, geralmente, para fora do país, e uma vez chegadas às capitais no estrangeiro, são aí forçadas a entregarem-se à prostituição. (WEISS ET FRENNELET - Pandectes françaises, vol. 49, V. Prostitution n- 165) Poucas resistem à imposição, a maioria, porém, sucumbe e sujeita-se ao exercício do torpe comércio, cuja regularidade é audaciosamente fiscalizada pelo homem a quem,

${ }^{106}$ Documentos 9, 11, 14, 17, 18, 21, 22 e 25; Apêndice B. 
tímida e receosa, presta contas diárias do respectivo produto" (Código Penal Brasileiro, editora Livraria Jacinto Editora, 1943, vol. V, págs. 128/129) ${ }^{107}$.

Nas situações em que ocorreu a edificação explícita de uma dignidade subalterna para a prostituta, mensurada pela chave do comportamento da vítima, ficou bastante claro o perfil que a legislação penal brasileira pretende atingir, prefacialmente, com o discurso de tutela dos direitos humanos consagrados em plano internacional: as prostitutas que performatizam o feminino. Há também, na prostituição, quem se identifique com o gênero masculino, mas não deixa de haver um endereçamento político mais destacado às mulheres (cis e trans) que entram no mercado do sexo, consoante exposto até aqui.

Justamente em razão desses meandros é pertinente endossar as lições de Leal (2013, pp. 45 e 55-56) quando afirma:

(...) o tráfico de mulheres, de acordo com os casos aqui tratados, é resultado das contradições do processo de globalização, acirradas pela crise de acumulação do capital e de seus impactos no mundo do trabalho em consonância com a questão de gênero. (...) Nessa esteira, as políticas de enfrentamento ao tráfico de pessoas só poderão responder aos direitos sociais e humanos se houver de fato uma mudança de paradigma nas políticas econômicas e de migração em âmbito transnacional de forma a romper com a criminalização e a política higienista desferida contra as mulheres em situação de migração irregular e tráfico para atividades laborais no mercado do sexo e em outras modalidades.

O desprezo do meio enganoso, fraudulento, coator ou abusivo como parte essencial do crime alimenta práticas de repressão que criminalizam a própria prostituição e não o tráfico. Quando se percebe, em termos analíticos, o tráfico de pessoas como fenômeno composto pela associação de um aspecto objetivo - centrado nos verbos de ação do art. 3ำ do Protocolo de Palermo - e de um aspecto subjetivo - concernente à percepção particular da vítima sobre a sedução, coação, submissão, escravidão, etc. (LEAL, 2013) —, noto que a cisão produzida pela legislação penal brasileira não é apenas um desvio acidental em relação ao padrão acordado internacionalmente. Trata-se de estratégia de mobilização dos órgãos do Sistema de Justiça Nacional em prol de uma bandeira moralizante das práticas sociais.

Compreendido, assim, o tráfico de pessoas enquanto construção social fortemente permeada pelas assimetrias de gênero, prosseguirei pelo mapeamento histórico do projeto ocidental destinado ao combate da prostituição, para, após, refletir sobre novas possibilidades de discursividade contra-hegemônica que podem emergir de uma aproximação pós-colonial e feminista do tema do tráfico internacional de mulheres para fins de exploração sexual.

${ }^{107}$ Documento 21; Apêndice B. 


\subsection{A prostituição como objeto histórico de combate}

A trajetória histórica dos movimentos internacionais de enfrentamento ao tráfico de pessoas foi permeada, constantemente, pela lógica de gênero e por uma especial preocupação com o tema da prostituição.

Foi assim desde 1904, quando, na Europa, se iniciaram as tratativas para reprimir o tráfico de mulheres escravizadas brancas, especialmente associado à migração de mulheres do Leste europeu e à prostituição e exploração sexual delas.

Ainda na primeira década do século XX, estava em curso o que se convencionou chamar de primeira onda do feminismo. Esse período do movimento feminista foi associado às lutas pelo sufrágio feminino, bandeira notada de forma mais consistente dentro dos Estados Unidos e no Reino Unido, durante o século XIX e no início do XX.

A Nova Zelândia foi o primeiro país a reconhecer esse direito das mulheres, no ano de 1893. Três décadas depois, o sufrágio feminino foi reconhecido no Reino Unido. Nas terras brasileiras, ele só veio a ser autorizado com o Decreto Presidencial no. . 21.076, de fevereiro de 1932, quando foi considerado eleitor o cidadão alistado maior de 21 anos, "sem distinção de sexo".

Os séculos XIX e XX também foram uma época de florescimento de demandas feministas embebidas do ideal de igualdade entre mulheres e homens - cisgênero - em termos de autonomia para contratar, casar e adquirir bens. Tratava-se de uma pauta formal de reconhecimento jurídico igualitário mínimo da cidadania das mulheres. Note-se, aqui, que homens e mulheres eram tomados enquanto blocos homogêneos por dentro e antitéticos por fora.

Também o debate em torno da prostituição tomou a cena nos países do centro, nas primeiras décadas do século XX. A evidência disso está nos sucessivos pactos internacionais sobre tráfico de mulheres e crianças para fins de exploração sexual nos anos de 1910, 1921, 1933, 1947 e 1949.

O princípio da busca de direitos pelas mulheres para obter equiparação jurídica e social com os homens também esteve presente na segunda onda do movimento feminista, ocorrida a partir da década de 1960, nos países anglo-saxões. O debate distinguia-se da primeira onda porque já não primava pela conquista de direitos políticos, já garantidos em grande parte do mundo - inclusive no Brasil. 
A meta era dar visibilidade à discriminação entre os sexos e combatê-la. Foi o tempo do apogeu da luta contra o patriarcalismo, entendido como o conjunto de estruturas rígidas de poder que conduziam à opressão das mulheres pelos homens. Instâncias como a família centrada na figura masculina, os baixos salários femininos, o descaso dos governos em face das necessidades surgidas com a entrada massiva das mulheres no mercado de trabalho eram repudiadas pela pauta feminista nesse tempo.

A partir da década de 1970, também ocorreu uma intensificação, nos países anglosaxões, das discussões em torno da pornografia e da prostituição, período em que, diferentemente, a produção acadêmica brasileira manifestava apenas um interesse sutil por esses temas, por estar menos articulada em torno da moral cristã de cunho abolicionista que tomava corpo no centro do globo. Nesse tempo, a pauta do ativismo feminista brasileiro estava centrada na oposição ao regime militar, na luta pela democratização e pela anistia, bem como em lutas específicas contra a dominação masculina, a violência contra as mulheres e o direito ao prazer (PISCITELLI, 2012).

Nesse particular, Margareth Rago (1995) conta que foi a partir da década de 1970 que despontou, entre sociólogas, antropólogas e historiadoras, a preocupação em identificar os signos da opressão masculina e capitalista sobre as mulheres. Tomaram conta da cena as péssimas condições de trabalho, os salários inferiores aos dos homens, o assédio sexual. $\mathrm{O}$ objeto de estudos era a mulher trabalhadora, identificada como produto das determinações econômicas e sociais, vítima das injunções do sistema. Desse modo, a segunda onda do movimento feminista brasileiro pensava o fim da discriminação entre os sexos sob os influxos da lógica de capital e trabalho, distanciando-se de pautas de cunho moral mais proeminente, como a da mercantilização sexual.

O grande exemplo da produção acadêmica dessa época foi o livro $A$ mulher na sociedade de classes: mito e realidade, de Heleieth Saffioti, escrito entre dezembro de 1966 e fevereiro de 1967. O objetivo da autora era demonstrar que o problema da marginalização social da mulher é uma questão permanente na "estrutura das sociedades capitalistas" (SAFFIOTI, 1979, p. 373). Defendia ainda que as formas de desvalorização do papel da mulher no sistema capitalista prejudicava tanto os homens quanto as mulheres dentro da esfera de manutenção da família. Estabelecia, por fim, que o antagonismo entre feminino e masculino somente poderia vislumbrar um horizonte de superação fora da sociedade de classes. 
Dentro desse paradigma, a mulher era vista sob enfoque globalizante e tinha sua subjetividade atrelada a certa passividade. Os estudos sobre a mulher tomavam-na, essencialmente, como ser que sofre as pressões da estrutura externa. Não como sujeito dotado de individualidade e capacidade de interferência nas relações de poder assentes.

Foi apenas na década de 1980 que o caldo teórico da produção acadêmico-feminista no Brasil engrossou de modo a mergulhar de forma mais capilarizada nos dilemas e nos complexos processos de exclusão e violência pelos quais passavam diferentes mulheres brasileiras. Conferiu-se, sob esse mesmo enfoque, destaque à atuação dessas mulheres como sujeitos dotados de histórias próprias. "Aí floresce um conjunto de estudos preocupados em revelar a presença das mulheres atuando na vida social, reinventando seu cotidiano, criando estratégias informais de sobrevivência, elaborando formas multifacetadas de resistência à dominação masculina e classista" (RAGO, 1995, p. 82).

Começam a surgir estudos para resgate da experiência de mulheres pobres e marginalizadas, trabalhadoras ou não, e para dar visibilidade à exclusão feminina do campo dos negócios e da política. Entre esses estudos, um sobre a violência contra as mulheres no início da República, de Raquel Soihet, e outro sobre a prostituição e o discurso médico, de Magali Engel, são apontados por Margareth Rago (1995).

Recordo que a década de 1980 raiou também como período de abertura do regime militar e redemocratização do país, o que favorecia a intensificação do diálogo crítico dentro do campo feminista. Os primeiros lampejos da uma proposta de reconstrução do ideário sobre o papel e o espaço social das mulheres surgiram nesse período. Havia espaço para contestar definições essencialistas do "ser mulher" e criticar a identificação do feminino a partir da perspectiva das mulheres brancas e das classes mais altas.

Inauguravam-se caminhos para entender a complexidade da diversidade de se pensar as mulheres sem se remeter a uma essência metafísica e única do ser feminino. A década de 1980 foi o campo da construção de andaimes para o diálogo que caracterizou a década de 1990 como o tempo da viragem para a terceira onda do feminismo global. Essa terceira onda propôs olhar criticamente para o próprio movimento feminista, questionando paradigmas globalizantes da construção social entre homens e mulheres. Era o advento do paradigma pósestruturalista que, com recurso à ideia de relações de gênero, dispunha-se a pensar os jogos relacionais e discursivos que proporcionam relações assimétricas de poder dentro da sociedade. 
Sob a influência das vertentes feministas da França e dos Estados Unidos, foram traduzidos livros sobre sexualidade, contracepção e aborto, reprodução, saúde e estereótipos na educação das mulheres no Brasil (PISCITELLI, 2012) ${ }^{108}$.

Esse momento poderia ter rendido ensejo à emergência de formas menos eurocêntricas de debater os direitos das mulheres no Brasil, abrindo um leque de oportunidades contrahegemônicas de pensar as prioridades do movimento dentro da realidade nacional. Contudo, da mesma forma que a década de 1990 anunciou um período de maior liberdade e complexidade das pautas feministas, essa mesma década albergou o fortalecimento de grupos feministas que se alinhavam às narrativas no centro global para rejeitar a possibilidade de que a prostituição voluntária pudesse ser vista como forma de trabalho. Essa negação vai tomando corpo especialmente quando se associam ao imaginário da prostituição as ideias de turismo sexual e de tráfico internacional de pessoas.

E é assim que se cogita, a contar do ano 2000, do advento de uma quarta onda do movimento feminista, cujo objetivo é promover uma estratégia transnacional de agência em defesa dos direitos humanos das mulheres, a partir do trabalho de mobilização no âmbito da sociedade civil.

Dentro da proposta de reunião de esforços para a criação de uma estratégia transnacional de atuação do movimento feminista, foram acirrados os embates morais em torno da prostituição quando se pensou a substituição da plataforma internacional de enfrentamento ao tráfico de pessoas de Lake Success, assentada em 1949.

O tema foi alvo de disputa entre as Organizações não Governamentais - ONGs que participaram das negociações prévias ao Protocolo de Palermo (NAÇÕES UNIDAS, 2003). A Assembleia Geral da ONU criou um comitê internacional global que se incumbiria de definir se a prostituição seria encarada como exercício da autonomia das mulheres ou exploração sexual (MENDONÇA, T.; 2014). Na primeira linha, destacavam-se as propostas da Human Right Caucus, na segunda, colocavam-se os anseios da Coalition Against Trafficking in Women (CATW).

\footnotetext{
${ }^{108}$ Comenta Rago (1995, p. 84): "Na década de 1980, amplia-se largamente o leque temático não apenas em relação à incorporação de novos agentes sociais, como mulheres, prostitutas, loucas, crianças, negros etc., mas principalmente em relação a dimensões da vida social privilegiadas pelos estudos da mentalidade e da sensibilidade. Temas como a história do corpo e da sexualidade; o poder médico e a loucura; a família, o amor e o pecado; a sedução e o poder, as representações da mulher nos discursos médicos e jurídicos; os códigos da moralidade feminina são incorporados como objetos históricos".
} 
A Human Right Caucus enfocava o abuso, o engano e a coação como características fundamentais do crime de tráfico, abrindo oportunidade para a regulamentação interna da prostituição pelos Estados-Partes. O consentimento da pessoa traficada somente deveria ser desconsiderado com relação a crianças e adolescentes, o que era um ponto pacífico dentro do movimento feminista.

A pauta da Human Right Caucus pressupunha um conceito mais elástico de tráfico de pessoas, para incluir o serviço forçado, a escravidão, a servidão e a exploração sexual, pontos incorporados na redação final do Protocolo de Palermo (NAÇÕES UNIDAS, 2003). Adotava, igualmente, um projeto protetivo independente do gênero, do trabalho ou do serviço prestado, dando visibilidade ao problema dos direitos das trabalhadoras do sexo, "reforçando que a violação de direitos e os riscos da atividade permanecem em razão da criminalização e das leituras moralizantes sobre o trabalho sexual, bem como da supressão de direitos das/os migrantes que trabalham com sexo" (MENDONÇA, T.; 2014, p. 48-49).

Em oposição a esse entendimento, a Coalition Against Trafficking in Women (CATW), identificava na prostituição em si uma forma de escravidão, por igualar pessoas a objetos. Associava, ainda, a prostituição ao mal do tráfico de mulheres e crianças no mundo, sintonizando-se com a Convenção e o Protocolo Final para a Repressão do Tráfico de Pessoas e do Lenocínio de Lake Success, de 1949. Por essa linha de intelecção, todos os grupos marcados como vulneráveis à mercantilização do sexo deveriam ser considerados vítimas, independentemente de idade ou consentimento. Essa, inclusive, era a lógica subjacente à proposta da CATW de intitular o Protocolo de Palermo como "Protocolo para Prevenção do Tráfico de Mulheres e Crianças”.

A Human Rights Caucus criticou a denominação recomendada pela CATW, por vislumbrar o reforço, nas suas entrelinhas, do estereótipo do migrante irregular homem que busca trabalho em face da migrante irregular mulher, traficada e vítima. Captava, assim, a futura ocorrência de distorções que se fizeram posteriormente presentes mesmo com a rejeição do título da CATW e a adoção de uma postura supostamente neutra pelo Protocolo de Palermo (NAÇÕES UNIDAS, 2003).

Os documentos temáticos mais recentes produzidos pelas Nações Unidas revelam que o consentimento em casos de mercantilização sexual e migração tem sido mais facilmente desconsiderado que o consentimento na migração em busca de outros campos laborais. Com isso, faz-se presente uma espécie de infantilização das mulheres cisgênero migrantes com relação ao tratamento destinado aos homens, justificada sob o manto da proteção. 
A exploração sexual é permanentemente ressignificada no tempo, na história e no lugar, mutabilidade que está intrinsecamente relacionada com a transformação da moral social. A questão que se coloca é refletir sobre até que ponto o alinhamento político com as estratégias de enfrentamento ao tráfico de pessoas dos países do centro responde às especificidades da realidade brasileira. Afinal, em nome de uma estratégia global de atuação feminista, convém universalizar a abordagem do tráfico, da prostituição e da exploração sexual?

Piscitelli (2012) conta que, recentemente, grupos como o das Feministas Jovens e o da Marcha Mundial de Mulheres pareceram se inclinar à negação da prostituição como trabalho e à afirmação da impossibilidade de regulamentação da prostituição, por sua violência sexista intrínseca. Outro elemento crítico do discurso desses movimentos feministas brasileiros mais recentes seria, segundo a autora, a impossibilidade da prostituição livre com recurso aos argumentos da pobreza e da violência estrutural que atravessa a vida de mulheres pobres e negras. Ainda nessa linha, emana o discurso da sensibilização pela dor vinculada à prostituição e o de criminalização de todo o entorno da atividade.

A autora não deixa de reconhecer que esse é um campo discursivo heterogêneo, mas espanta-se com a forma como vieram se avolumando os esforços pela institucionalização de mecanismos de abolição da prostituição no país em tempos recentes. Aqui, como no discurso do CATW, a prostituição passa a ser vista por parte das ONGs que transitam pelas instâncias de poder político institucionalizado como o oposto da sexualidade legítima, à condição de normalidade da mulher. Com isso, a agenda e os debates sobre prostituição e tráfico acabaram se alinhando com propostas de controle ostensivo da migração feminina e da prostituição encabeçadas nas políticas dos países do centro (PISCITELLI, 2012; KEMPADOO, 2005).

Essa teia discursiva tem orientação muito semelhante à viragem sentida por Elisabeth Bernstein (2007) dentro das narrativas estadunidenses de enfrentamento ao tráfico na última década. Relata que, enquanto, na década de 1990, a perseguição dessas atividades estava ligada cultural e politicamente à defesa dos direitos das pessoas que trabalhavam com sexo, essa moldura foi sendo paulatinamente substituída por políticas federais que igualam toda prostituição ao crime de tráfico de pessoas e que capturam, de forma retórica, todas as atividades do comércio sexual dentro do rótulo de escravidão sexual.

Para além disso, explica que, nos Estados Unidos, parece ter se formado uma aliança espúria entre o projeto cristão evangelizador de "humanização militarizada" ao feminismo secular que incita o encarceramento com relação às práticas que integram o rol de 
mercantilização do sexo. A agenda dos dois grupos, segundo a autora, contempla a meta de abolição da prostituição, classificada como "antítese da liberdade". O meio eleito por ambos é a pressão por leis que favoreçam o recrudescimento do controle policial.

O pressuposto é o retorno a uma construção universal de um parâmetro de exercício regular da sexualidade da mulher, elaborado a partir de padrões sexuais hegemônicos nas elites culturais do mundo ocidental. O discurso normalizador do exercício da sexualidade pelo padrão abolicionista estadunidense traduz uma agenda neoliberal que não culpa as instituições ultrapassadas pelos problemas sociais, mas se centra em desvios e patologias individuais. Demais disso, o enfoque etiológico e repressivo da mercantilização do sexo elege a Justiça Criminal como espaço adequado para solucionar esses desvios, silenciando sobre o papel jogado pelas assimetrias na distribuição de recursos e oportunidades do sistema capitalista.

Se o discurso abolicionista brasileiro até um século atrás parecia rejeitar a regulamentação da prostituição por entendê-la como forma insidiosa de aplicar uma política higienista de controle da mulher, o reflexo recente das narrativas sobre o tráfico sexual de mulheres faz surgir um novo abolicionismo que não se preocupa tanto com as formas de exclusão assimétricas que a regulamentação da atividade pode conter, pois, antes, rejeita qualquer forma de regulamentação da mercantilização do sexo enquanto violência em si.

Esse tipo de perspectiva se faz sentir no material examinado ao longo da pesquisa. Uma das sentenças cuida de maneira especial do tema da legalização da prostituição. Nela, o julgador elenca uma série de razões pelas quais a mercantilização do uso do corpo é, em si, uma violência e deve ser contida pelo controle policial ostensivo, especialmente nas fronteiras:

Muitas pessoas acham que a legalização ou descriminalização da prostituição traria dignidade e profissionalismo para as mulheres em prostituição, argumentando, basicamente, que: a) a prostituição adulta deve ser encarada da mesma forma da liberdade de expressão, religião e comércio, não cabendo ao governo realizar escolhas pelas pessoas; b) a legalização da prostituição trará o gerenciamento das condutas, banindo os cafetões e prevenindo a prostituição clandestina; c) a legalização trará direitos de seguridade social às mulheres, além de um melhor atendimento médico, prevenindo doenças sexualmente transmissíveis; d) a legalização dignificará a prostituição como qualquer outra profissão.

Uma das primeiras questões a esse respeito é saber se a dignificação da prostituição fará o mesmo com a mulher, ou seja, será que a legalização ou descriminalização da prostituição trará dignidade para a mulher prostituída ou apenas para a indústria do sexo? Questionamos, assim, se os consumidores das atividades femininas seriam aceitos como legítimos consumidores do sexo e se a mulher em tal atividade seria aceita como uma trabalhadora comum. Cremos que não. 
Outrossim, se mesmo empresas de ramos tradicionais sonegam impostos, o que se dirá caso a prostituição seja legalizada, ou seja, a legalização/descriminalização da prostituição não fará desaparecer a prostituição clandestina seja para não serem efetuados os pagamentos dos impostos devidos, seja por não atenderem às exigências certamente feitas no que diz respeito à vigilância sanitária dos estabelecimentos ou como forma de preservar o anonimato das mulheres.

Revela-se, outrossim, amplamente discriminatório falar-se em controle da saúde pública através do monitoramento apenas das prostitutas com relação a doenças sexualmente transmissíveis, vez que, obviamente, são os homens que também as transmitam [sic].

Deve-se, ainda, examinar criteriosamente o que se entende por liberdade de escolha, vez que a maioria das mulheres na prostituição não realizaram uma escolha racional e verdadeiramente livre para entrar em tal atividade, mas simplesmente realizaram uma opção de sobrevivência que, na maioria dos casos, sequer foi uma opção, vez que era a única.

Ademais, legalizar a prostituição parece ser uma maneira simples de dizer aos governantes que eles não precisam se preocupar em melhorar as condições das populações, vez que sempre haveria a porta da prostituição, abdicando da responsabilidade de promover um decente e aceitável emprego.

No Brasil, por identificar a dignidade da pessoa humana como fundamento do nosso Estado Democrático de Direito (art. 1o-, III da Constituição de 1988), tal legalização é constitucionalmente defeso [sic], o que não significa deixar de reconhecer a necessidade de amparo e defesa das pessoas exploradas em tais atividades ${ }^{109}$.

\section{Prossegue:}

Verifica-se, no entanto, que a pobreza é insuficiente para criar uma legião de prostitutas, mas o fazem as percepções ainda silenciosamente cultivadas em nossa sociedade em relação às mulheres, ou seja, aquelas que estabelecem como única coisa de valor na mulher a sua liberdade sexual que, através de seu corpo, tem se transformado em uma ação vendável. É, pois, a cultura machista ainda vigente em nossa sociedade que partindo da percepção da mulher sem nome, sem família, passado, sem vida e sem vontade, autoriza a prostituição. É nessa cultura invisível que o poder econômico e social cria o silêncio a respeito de quem está sendo explorado, machucado e usado, na penosa constatação de que não se tem a quem recorrer, não se tem a onde ir [sic] e na impressão íntima de que não se é nada. Outro conceito típico de nossa condição de classe média é que as prostitutas são sujas e contagiosas, fontes de tudo o que é ruim e errado, pelo que é vista [sic] como alguém que merece uma punição que a própria vida lhe oferece e não todo tipo de cuidado ou atenção.

Além de se combater a pobreza, do incesto e das violências sexuais sofridas na infância [sic] que empurram a mulher para fora da família e para as profundezas da prostituição, há, pois, que se enfrentar tal cultura, sendo certo que a solução é obviamente política e deve também atingir diretamente os homens que utilizam a prostituição, mas não apenas com penas restritivas da liberdade, mas com pesadas multas e mesmo intervenção estatal, em forma de liquidação

${ }^{109}$ Documento 28; Apêndice B. 
forçada, das empresas criadas ou utilizadas de forma preponderante para o tráfico de mulheres, a exemplo da previsão do art. 24 da Lei Ambiental (Lei 9.605, de 12 de fevereiro de 1998).

Na verdade, cremos que a única prevenção possível seja a prevenção social, qual seja, a ampliação do acesso à educação e à saúde, aumento do acesso da mulher ao mercado de trabalho, maior controle e vigilância nas regiões de fronteira, com imediato treinamento das autoridades encarregadas da expedição de passaportes para prestarem esclarecimentos em entrevistas pessoais com mulheres suspeitas de futura prostituição. Disseminação, por meio de todas as formas de mídia, de informações que auxiliem a prevenir o tráfico e permita que as pessoas denunciem sua prática, bem como cartilhas informativas distribuídas por ocasião da expedição de passaportes ou mesmo impressão de como realizar tais denúncias nos próprios documentos de viagem e/ou passaportes são outras medidas simples de prevenção (grifos acrescidos) ${ }^{110}$.

A adoção de uma perspectiva abolicionista se conecta com as premissas de que prostituição é, necessariamente, assédio, abuso e violência, o que se associa à précompreensão de que "as mulheres nunca entram livremente em relações sexuais fora do 'amor' ou do desejo sexual autônomo" (KEMPADOO, 2005, p. 58).

Por esse viés, tem-se o negligenciamento de dois elementos do capitalismo tardio captados por Bernstein (2008, p. 353): “a relação entre a pobreza pós-industrial e a gentrificação ${ }^{111}$, e o impulso normativo de algumas feministas no sentido de reter um modelo modernista de intimidade sexual delimitada de maneira relacional" em face da proposta recreativa do sexo mercantil.

No projeto abolicionista, seja ele religioso ou secular, a prostituta é normalizada tanto quando lhe é atribuído o status de criminosa, quanto o de vítima. Isso, aliás, ficou bem evidente nas decisões do Judiciário brasileiro. Em sua maioria, faziam utilização mais frequente do termo vítima do que do termo prostituta ou de seus equivalentes (garota de programa ou meretriz, por exemplo). Sem embargo, quando era narrada a opção prévia ao ato de migrar pelo exercício da prostituição no exterior, imputava-se à ofendida a responsabilidade por facilitar o tráfico internacional para fins de exploração sexual, o que deveria ser abatido da pena imputada às pessoas acusadas.

Também pelo prisma da abolição da atividade de prostituição, são reafirmadas a tônica da deportação - que ainda emerge de Palermo (NAÇÕES UNIDAS, 2003), como bem

\footnotetext{
${ }^{110}$ Documento 28; Apêndice B.

${ }^{111}$ A gentrificação aparece como reestruturação de espaços urbanos com a substituição de residências e pequenos comércios locais por grandes edifícios e pontos comerciais que inflacionam a região, em prejuízo da população de baixa renda que originalmente ocupava o local, por sua natureza de privatização excludente.
} 
aponta Ausserer (2011) - e a do refreio à migração de mulheres cisgênero, conclusão que converge com o conteúdo da decisão acima.

Então, convém pensar: se a prostituição, dentro do próprio movimento feminista, é demonizada e entendida como exercício anormal da sexualidade feminina, nada impedirá que o código moral abolicionista verta livremente pelos caminhos da prevenção pelo medo e do recrudescimento dos controles policiais e migratórios sobre a mulher.

Esse é o grande risco de subversão da pauta feminista de proteção das mulheres com relação ao mercado do sexo. Além disso, o engajamento do feminismo no projeto de controle da atividade criminosa internacional pode, inclusive, prejudicar projetos pessoais de vida no exterior e alimentar uma política segregacionista dos países do centro em relação aos países da periferia do mundo globalizado, num contexto de acentuação radical das distorções econômicas do modo de produção capitalista (QUIJANO, 2002).

Decerto que, como anteriormente mencionado, a conformação de uma nova pauta abolicionista no Brasil não parece ocorrer em um cenário ideológico homogêneo, havendo vertentes do movimento feminista que defendem a regulamentação da prostituição e outras a interpretarem que essa regulamentação não se relaciona apenas com o empoderamento e a autonomia da vontade, mas também com a saúde sexual das prostitutas. Com isso, há uma margem importante para a revisitação das práticas e dos discursos pautados diante do governo.

Outro ponto positivo dessa heterogeneidade de pensamento é que ela se combina com a diversidade que o próprio mercado sexual abrange em termos de classe, etnia, gênero e lugar. O exercício da prostituição, a entrada na indústria pornográfica digital e impressa, o trabalho com danças sensuais são realidades permeadas por múltiplos e complexos fatores que não poderiam ser enfrentados com um discurso uniforme simplificador.

Há quem, como Carole Pateman (1993), repudie a existência de prostituição voluntária, presumindo que a sexualidade está necessariamente ligada à identidade e à subjetividade. Por essa linha, não se poderia comprar um serviço sexual, pois o pagamento não se daria sobre o serviço, mas sobre a objetificação da pessoa que se prostitui ${ }^{112}$.

\footnotetext{
${ }^{112}$ Nas palavras da autora: "Há uma relação essencial entre o corpo e o ser. O corpo e o ser não são idênticos, mas os seres são inseparáveis dos corpos. A ideia de propriedade na pessoa tem o mérito de chamar atenção para a importância do corpo nas relações sociais. (...) A masculinidade e a feminilidade são identidades sexuais; o ser não está completamente subsumido na sua sexualidade, mas a identidade é inseparável da construção sexual do ser. No patriarcado moderno, a venda de corpos femininos no mercado capitalista envolve a venda do ser de uma maneira diferente, e com um sentido mais profundo, do que a venda do corpo
} 
De outro lado, autoras como María Luisa Maqueda Abreu ${ }^{113}$ entendem que essa explicação tem orientação ideológica de cunho generalizante, sendo insuficiente para justificar que toda forma de mercantilização do sexo é violência. Nesse sentido, cuidam de assinalar que, dentro do que se pode enquadrar como tráfico de pessoas com fins de exploração sexual, há muitas mulheres que carregam seus projetos migratórios que, ainda que perpassem o exercício da prostituição - com todas as implicações morais que dificultam seu entendimento - denotam a consciência e o desejo de trilhar um projeto de vida próprio, por vezes compartilhado no âmbito familiar e comunitário.

Não fosse assim, o tema da deportação, esta aqui entendida como ato de reordenação do Estado-Nação, deixaria de ser tão nevrálgico sob a perspectiva da realização dos sonhos de quem migra. Essa projeção de uma vida melhor parece inextricavelmente associada à construção subjetiva da identidade da pessoa, razão pela qual merece ser tomada em sua importância.

Os discursos que trabalham pela contenção da migração de mulheres indocumentadas estão majoritariamente associados à ideia da prostituição, ainda que esse seja apenas um dos campos de atividade em que essas pessoas podem se inserir no destino em busca de superação pessoal. Com isso, o próprio fato de que o discurso abolicionista esteja se avolumando em tempos recentes reitera o pré-conceito de que toda migração feminina tende ao mercado do

de um jogador de beisebol ou a venda do domínio da utilização do trabalho (corpo) assalariado. A história do contrato sexual revela que a construção patriarcal da diferença entre masculinidade e feminilidade é a diferença política entre liberdade e sujeição, e que o domínio sexual é o principal meio pelo qual os homens afirmam sua masculinidade. (...) A feminilidade, também, é confirmada pela atividade sexual, e, portanto, quando uma prostituta contrata a utilização de seu corpo por outra pessoa, ela está vendendo a si mesma, num sentido bastante concreto. Os seres das mulheres estão envolvidos na prostituição de uma maneira diferente do ser em outras ocupações. (...) Quando os corpos das mulheres estão à venda como mercadorias no mercado capitalista, os termos do contrato original não podem ser esquecidos; a lei do direito sexual masculino é afirmada publicamente, e os homens recebem um reconhecimento público enquanto senhores sexuais das mulheres - e é isto que está errado com a prostituição" (PATEMAN; 1993, p. 302-305).

${ }^{113}$ Sobre o abolicionismo da prostituição, afirma Maqueda Abreu: "Não é de se estranhar que, sob estes pressupostos ideológicos, confundam-se, tão comumente, prostituição e tráfico, quando quem presta os serviços sexuais são imigrantes. À vulnerabilidade simbólica que arrasta o gênero - mulheres 'enfraquecidas' por abusos na infância, mulheres 'inocentes e submissas' -, associam-se agora outras formas de desvalorização por razões de etnia - mulheres 'atrasadas e ignorantes' - ou econômicas - mulheres 'pobres e sem recursos', que favorecem sua vitimização (Agustín). Os meios de comunicação e muitos informes 'bemintencionados' contribuem para esse 'olhar colonial' que ativa todo um dispositivo tutelar que as prejudica, porque seu efeito é o controle e a opressão estatal. São, parece, males menores para o feminismo abolicionista. Em seu afã por erradicar a violência de gênero que se associa ao sexo por dinheiro - leia-se prostituição e tudo o que tenha a ver com ela - esquecem a urgência de uma cidadania laboral para as mulheres em nosso mundo globalizado. A velha ideia de salvação, de reabilitação - para apagar o signo da degradação - substitui o necessário empoderamento das trabalhadoras sexuais para decidir o rumo de suas vidas" (MAQUEDA ABREU; s/d, p. 8-9. Tradução livre). 
sexo, o que favorece a criação de barreiras migratórias internacionais cada vez mais espessas e difíceis de transpor, em razão do gênero ${ }^{114}$.

Enfim, a narrativa abolicionista parece eclipsar uma lógica colonial insidiosa de controle da mobilidade das mulheres, o que não detém somenos importância no campo da proteção dos direitos humanos, já que reitera o processo de segregação territorial de que cogita Bauman (2005) ao falar das angústias de manutenção do Estado-Nação no contexto de globalização:

O objetivo mais ampla e intensamente cobiçado é a escavação de trincheiras profundas, possivelmente intransponíveis, entre o "dentro" e o "fora" de uma localidade territorial ou categórica. Fora: tempestades, furacões, ventos congelantes, emboscadas na estrada e perigos por toda parte. Dentro: aconchego, cordialidade, chez soi, segurança, proteção. Já que, para manter o planeta inteiro seguro (de modo que não precisemos mais separar-nos do inóspito "lado de fora"), nos faltam (ou pelo menos acreditamos que nos faltem) ferramentas e matériasprimas adequadas, vamos construir, cercar e fortificar um espaço indubitavelmente nosso e de mais ninguém, um espaço em cujo interior possamos nos sentir como se fôssemos os únicos e incontestáveis mestres.

A pressuposição de que a prostituição não pode caracterizar serviço em nenhuma hipótese - não se podendo cogitar de seu exercício como trabalho — também tem impactos reais na vida de quem está no mercado sexual, dada a compreensão pacífica de que esse processo de ocultamento da atividade redunda em perigosos cenários de violência do próprio comércio do sexo e por parte das instituições públicas de controle, como é o caso dos abusos policiais.

A definição da prostituição voluntária como violência ou não violência impacta o conteúdo da exploração que integra a definição do tráfico. Formulam-se, então, as seguintes perguntas: em que medida a associação necessária entre prostituição e tráfico não contribui para a precarização das condições de vida e trabalho no mercado do sexo ${ }^{115}$ ? Será que os meios de proteção utilizados não merecem ter suas bases novamente refletidas por veicularem um projeto paternalista de normalização da sexualidade feminina?

\footnotetext{
${ }^{114}$ Essa mesma ideia pode ser transladada para o universo da migração de transgêneros.

${ }^{115}$ Essa inquietude também é demonstrada na produção de Kamala Kempadoo. Afirma: "Existe atualmente uma indústria antitráfico que inclui números crescentes de assistentes sociais, políticos, pesquisadores 'czares' antitráfico e funcionários da imigração, e também leis e políticas novas e fundos e recursos especialmente dedicados para trabalho contra o tráfico, assim como um conjunto de novas medidas e métodos para prender os traficantes e prestar assistência às 'vítimas', sem que se possa demonstrar que tenham tido muito impacto nas vidas das mulheres pobres” (KEMPADOO, 2005, p. 72).
} 
A resposta a essas postulações não é simples, pois a prostituição não é um fenômeno unívoco ou uniforme, adquirindo diferentes formas de acordo com os contextos e os mercados, bem como em virtude de influxos históricos e culturais ${ }^{116}$.

Não ignoro que, do mesmo modo que o abolicionismo vitimiza a prostituta que o faz voluntariamente, objetificando-a em seu labor e prejudicando o reconhecimento de seus direitos, ele acerta ao alertar para os casos em que a prostituição envolve violência, abuso ou fraude contra as mulheres. Suscita a relevância do cuidado em casos nos quais a extrema pobreza ou outras formas de profunda vulnerabilização, como o financiamento do uso de drogas, acompanham o exercício da atividade ${ }^{117}$.

Esse impasse transparece em uma das decisões analisadas. Na contramão das demais, a argumentação utilizada pelo julgador seguiu parâmetros doutrinários de outros autores que não Magalhães Noronha, Paulo José da Costa Jr., Mirabete e Fernando Capez — mais citados nas decisões do corpus documental — para, primeiramente, afirmar que a consumação do crime somente ocorre com o efetivo exercício da prostituição no exterior, e não com a simples tentativa de emigração para exercício da prostituição. Disse o magistrado:

Importa considerar, ainda, que, para a consumação do delito, é imprescindível que haja a demonstração da efetiva prática do meretrício pela pessoa traficada, não bastando a mera consciência pelo agente de que o ingresso ou a saída da pessoa do território nacional tem por objetivo o exercício da prostituição. Repita-se, para a consumação do delito ora em análise, necessário que ocorra o exercício efetivo da prostituição, tratando-se, portanto, de crime material.

Neste sentido, leciona o autor Guilherme de Souza Nucci, in verbis:

"O conceito de prostituição já implica no exercício habitual do comércio da atividade sexual. É mais uma modalidade de crime cujo verbo principal exige um complemento habitual. Para consumar-se, portanto, é indispensável uma verificação minuciosa do ocorrido após a entrada da pessoa no território nacional ou depois que ela saiu, indo para o estrangeiro. Afinal, ainda que a pessoa ingresse no Brasil para exercer a prostituição, mas não o faça, inexiste crime. Não é delito formal, mas material, demandando o efetivo exercício da prostituição".

\footnotetext{
${ }^{116}$ Complementa Daich (2012, p. 79. Tradução livre): “A prostituição é problemática por si porque, por baixo da cobertura de uma aparente definição trans-histórica e transcultural, reúne ou condensa vários significados, porque fala de um vasto e diverso mercado do sexo em que inúmeros cenários são possíveis. As microcenas que precedem permitem que formemos apenas uma pequena ideia da complexidade da problemática. A prostituição se refere apenas a uma dentre tantas atividades possíveis dentro de um mercado sexual maior que inclui, por exemplo, a pornografia, o sexo telefônico e virtual, e a 'dança exótica', entre outras. A prostituição é um sistema onde o estigma socialmente produzido funciona como uma estratégia patriarcal que atenta contra a autonomia das mulheres (Juliano, 2002), mas é também um sistema estratificado no qual as distintas hierarquias sociais - classe, etnia, idade - operam de maneira diferencial na reprodução de desigualdades".

${ }^{117}$ Ainda nesses casos, a narrativa de controle policial não parece responder de forma suficiente ao problema. Pelo contrário, o submerge ainda mais e acentua a marginalização que diz combater, como elucida Kempadoo (2005).
} 
Do mesmo modo, preleciona Rogério Greco sobre a necessidade do efetivo exercício da prostituição para configuração do crime de tráfico internacional de pessoas, consoante se infere do texto abaixo transcrito:

"A lei penal, ao narrar o comportamento proibido, utiliza as expressões pessoa que venha a exercer a prostituição e para exercê-la no estrangeiro, pressupondo, pois, a necessidade do efetivo exercício da prostituição para que se reconheça a consumação do delito" ${ }^{118}$.

Forjou, na sequência, a distinção entre o exercício da prostituição e a prática do "alterne"119, com o que afastou o enquadramento dos fatos ao tipo penal do tráfico internacional de pessoas para fins de exploração sexual. Trouxe para o ato decisório falas das mulheres supostamente ofendidas e nisso se firmou para argumentar que, não tendo havido qualquer forma de limitação da liberdade das mulheres ou de desrespeito à sua dignidade, impunha-se a absolvição das pessoas acusadas. Seguem trechos da sentença:

No caso brasileiro, tendo em vista o perfil das vítimas deste delito, bem assim o lucro normalmente auferido por seus agentes, pode-se mesmo afirmar que o crime em comento não atenta somente contra os bons costumes, mas também e, em especial, contra os princípios da valorização e da dignidade da pessoa humana, fundamentos do nosso Estado Democrático de Direito (...).

De fato, não há dúvidas de que as vítimas do tráfico internacional ou interno de pessoas são tratadas pelos agentes dos delitos, não raras vezes organizações criminosas, como mercadorias, sendo atraídas pela falta de oportunidade no Brasil, de modo que a tutela penal se justifica também pelo grande mal que essa prática ocasiona à dignidade da pessoa traficada, à sua família, à sociedade e ao Estado, em face dos problemas sociais dela resultantes.

Quanto à configuração do crime em referência, dá-se pela prática de uma das condutas alternativas ou mistas previstas no tipo penal, a saber: promover, que significa ser a causa geradora de algo, tomar a iniciativa; intermediar, que quer dizer servir de ponte ou estar no meio das pessoas, aproximando-as; e facilitar, que é tornar acessível, mais fácil, ajudar na entrada ou saída do território nacional de pessoas para fins do exercício da prostituição. Essa última conduta pode ser praticada por qualquer meio, tais como o fornecimento de dinheiro, o pagamento das despesas com os preparativos da viagem ou o fim da prostituição, o fornecimento ou retirada de papeis ou documentos pessoais, como passaporte, dentre outros.

No caso em apreço, do exame do conjunto probatório não restou demonstrado que os acusados promoveram, intermediaram ou facilitaram a saída de pessoas do Brasil com o fim de se prostituírem, conduta que se caracteriza, muitas vezes, pela cobrança de dívidas infundadas e indevidas, retenção de documentos, encarceramento e ameaças.

In casu, todas as supostas vítimas ouvidas em Juízo foram uníssonas em afirmar que saíram do Brasil cientes tanto da dívida que tinham para com os réus - pois

\footnotetext{
${ }^{118}$ Documento 29; Apêndice B.

${ }^{119}$ Atividade explicada pelo magistrado no excerto que segue.
} 
eles haviam pago as passagens aéreas e providenciado a documentação necessária à concessão do visto de turista, embora, algumas vezes, ficassem sabendo do valor apenas em Portugal, após conversa com (...), quanto da forma como essa dívida seria paga, por meio de descontos na remuneração recebida, de modo que não há nos autos elementos que levem este Juízo a crer que a dívida contraída pelas mulheres se mostrava abusiva ou indevida.

De igual forma, as supostas vítimas também foram unânimes em dizer que não eram obrigadas a fazer nada além da atividade da dança, sendo livres para fazerem o que bem entendessem, inexistindo, ainda, qualquer tipo de ameaça à sua integridade física e/ou moral, tampouco a apreensão de seus passaportes, o que poderia inviabilizar seu retorno ao Brasil.

Em verdade, dos depoimentos colhidos por este Juízo, especialmente os das supostas vítimas, restou claro que as brasileiras iam a Portugal para, finalisticamente, participar de shows de dança ou "fazer consumação", a chamada prática do alterne, sem haver qualquer induzimento ou ordem dos acusados para que se submetessem à prostituição. Também comprovado não ter havido cárcere privado ou qualquer outra forma de limitação à liberdade - procedimento típico no cometimento do tipo imputado.

A respeito disso, essencial destacar a conotação dada à prática do alterne, que, na maioria das vezes, mostra-se associada à prática da prostituição. Contudo, pelos depoimentos colhidos por este Juízo, tem-se que a prática do alterne, consistente em entreter os clientes, estimulando-os a comprar bebidas no estabelecimento, com o intuito de obterem percentual sobre o preço da bebida servida, é distinta daquelas praticadas em casas de prostituição.

(...)

Deste modo, não se comprovou nos autos a prostituição narrada na denúncia. Ao contrário. Todas as testemunhas elencadas pelo Parquet, além das arroladas pela defesa dos réus foram enfáticas ao declinar que não se prostituíram no período em que trabalharam nas casas noturnas de Portugal, tendo algumas asseverado, ainda, que sequer viram qualquer ato de prostituição nos estabelecimentos.

Noutro pórtico, também não se configurou nos autos a coação, elemento inerente a esses casos de tráfico para fins de exploração sexual, pois, além de as dançarinas não ficarem presas em seus locais de trabalho, tendo plena liberdade de locomoção, ficaram na posse de seus passaportes, podendo voltar ao Brasil no momento em que desejassem, consoante se infere dos depoimentos, dentre outros, das testemunhas ${ }^{120}$.

O grande problema da narrativa hoje veiculada na maioria dos processos brasileiros sobre tráfico internacional de mulheres cisgênero é que "os matizes e diferenças se diluem no discurso abolicionista" (DAICH, 2012, p. 78. Tradução livre), forma de essencialização que parece jogar justamente na contramão das lutas feministas por emancipação e reconhecimento de direitos. Por outro lado, situações como a da decisão acima levam a refletir sobre como a

${ }^{120}$ Documento 29; Apêndice B. 
proteção de mulheres migrantes quanto à fraude, ao engano, à coação e qualquer outra forma de violência ficaria potencialmente debilitada, caso somente se entendesse que, enquanto não consumado o exercício forçado da prostituição, não haveria tráfico de pessoas. Outro problema está, ainda, no risco de que as testemunhas sofram algum tipo de intimidação no ato de depor, que impeça a visualização de uma violência efetivamente ocorrente.

Aqui reside uma inquietação pelo desenvolvimento de uma nova linguagem de proteção da liberdade e da sexualidade femininas na sociedade pós-colonial. É importante pensar em formas discursivas que permitam dialogar sobre os direitos humanos sem reproduzir opressões, estigmas e violências. Encontrar caminhos para falar da liberdade e da autorrealização das mulheres sem precisar afirmar esses valores mediante uso de mecanismos de repressão. Pensar em soluções que empoderem e protejam a mulher brasileira em primeiro plano, acima da moralidade pública e da defesa dos costumes de uma sociedade comandada por uma racionalidade capitalista andro-cis-heteronormativa.

\subsection{Possibilidades de aproximação pós-colonial e feminista sobre a questão do tráfico internacional de mulheres cisgênero para fins de exploração sexual: sobre a limitação do discurso penal repressivo e a necessidade de reinvenção humanista do projeto de proteção da mulher}

Como demonstrei anteriormente, a subjetividade das mulheres ofendidas não foi plenamente resgatada nas sentenças e nos acórdãos penais sobre tráfico internacional de pessoas para fins de exploração sexual. A transcrição das suas falas com relação aos fatos investigados até chegou a ser feita em mais da metade das decisões examinadas e, em algumas poucas, a importância do testemunho, da narrativa das vítimas, sobre a experiência de migração foi salientada. Não obstante, foi o suficiente para a condenação pelo crime de tráfico internacional de pessoas o simples relato de que tanto as mulheres que migravam quanto os acusados tinham consciência do potencial exercício da prostituição no exterior.

A letra seca do Artigo 231 do Código Penal foi aplicada e não houve espaço privilegiado de discussão para análise da ocorrência de fraude, coação, engano, compra do assentimento ou qualquer forma de violência. A mera colaboração consciente com o projeto pessoal de prostituição da mulher cisgênero migrante é suficiente, pela leitura do Judiciário nacional, para fazer incidir o peso da lei penal. Os parâmetros mais amplos do Protocolo de Palermo (NAÇÕES UNIDAS, 2003) e mesmo da Política Nacional de Enfrentamento ao 
Tráfico de Pessoas ${ }^{121}$, que atraem uma imersão sobre a subjetividade e a experiência das vítimas, adquiriram feição meramente ilustrativa no discurso de repressão ao tráfico de pessoas.

Reflexos da aplicação seca da lei foram sentidos na igualação entre as situações de restrição da liberdade sexual das pessoas supostamente traficadas e aquelas em que não houve qualquer indício de limitação da autonomia e da liberdade das mulheres migrantes. Neste passo, ficaram latentes as mensagens de que havia um código moral a ser resguardado dentro dos processos migratórios de mulheres cisgênero no país e de que a lei penal deveria servir de reforço a este código, independentemente da lesão ou do perigo de lesão à dignidade e à liberdade sexual da mulher que migrou.

A ocultação das vozes das vítimas não pode ser exclusivamente atribuída aos julgadores. O Código Penal Brasileiro exara o comando objetivo de apenação de quaisquer formas de favorecimento, intermediação ou auxílio à migração para a prostituição. Utiliza a fraude e o intuito de lucro apenas como fatores para elevação da pena acima do mínimo ou aplicação concomitante de multa ${ }^{122}$.

A presunção de vulnerabilidade das migrantes, entretanto, emerge do discurso contido em parte das sentenças e dos acórdãos, mesmo não figurando como requisito para a condenação dos acusados. Mesmo em casos em que não estavam descritos elementos ou circunstâncias que permitissem antever uma fragilidade tão intensa, a ponto de afastar a liberdade de opção pela migração para prostituição, proferiu-se o discurso de vulnerabilidade, de incapacidade de consentir, de falsa liberdade, ingenuidade e ilusão como justificativa moral para aplicação da lei penal incriminadora do tráfico internacional de pessoas.

A associação entre a objetividade da lei penal, que despreza a subjetividade das vítimas do tráfico de pessoas para fins de exploração sexual, e a presumida vulnerabilidade das mulheres cisgênero que migraram, faz parte de um ideário orientado à abolição da prostituição. Entre o risco da desproteção quanto à exploração sexual e o do paternalismo jurídico que infantiliza e despreza o poder da mulher cisgênero sobre a própria sexualidade, é

\footnotetext{
${ }^{121}$ Decreto no ${ }^{\circ}$. 5.948/2006.

122 Artigo 231: "Promover ou facilitar a entrada, no território nacional, de alguém que nele venha a exercer a prostituição ou outra forma de exploração sexual, ou a saída de alguém que vá exercê-la no estrangeiro. Pena reclusão, de 3 (três) a 8 (oito) anos. $\S 1$ o Incorre na mesma pena aquele que agenciar, aliciar ou comprar a pessoa traficada, assim como, tendo conhecimento dessa condição, transportá-la, transferi-la ou alojá-la. $\S 2$ o A pena é aumentada da metade se: (...) IV - há emprego de violência, grave ameaça ou fraude. § 3ำ Se o crime é cometido com o fim de obter vantagem econômica, aplica-se também multa." (Redação conferida pela Lei n 12.015, de 2009).
} 
o paternalismo a opção de política criminal adotada no país. Aliás, emerge das decisões uma inclinação ideológica pelo próprio recrudescimento dos controles migratórios, a incidir sobre qualquer mulher que possa ter a intenção de migrar para se prostituir.

Essa escolha política tem limitações de duas ordens. Embora possa realmente facilitar a prova e, por conseguinte, a condenação nos casos em que a liberdade e a dignidade sexuais da mulher migrante são violadas, por outro prisma, reprime a liberdade sexual das mulheres que pretendem se prostituir por enxergarem nesta profissão oportunidades de ascensão social, profissional e econômica atraentes. Em segundo lugar, funciona como perigoso instrumento de bloqueio da liberdade de deslocamento internacional das mulheres, independentemente dos projetos que pretendam executar no exterior. Aqui, a discriminação de gênero pode assumir uma das suas facetas mais perversas, sob o manto de uma narrativa "bem-intencionada".

A ideia de migrar internacionalmente é corriqueira no imaginário social do fim do século XX e do alvorecer do XXI. É uma possibilidade bastante palatável e concreta, no contexto de globalização da economia e de intensificação dos fluxos de pessoas, conhecimento e informação. A dúvida é: pertence legitimamente às estruturas institucionais do Poder Público a escolha sobre se uma mulher pode ou não buscar emigrar, independentemente da atividade que pretenda realizar no exterior? Entendo que não, sob pena de quebra da isonomia que a própria Constituição Federal de $1988^{123}$ confere ao tratamento das pessoas independentemente de sexo.

Temos então outro problema: a prova da materialidade do tráfico internacional de pessoas não se tornaria muito mais difícil de produzir se a subjetividade das vítimas fosse marcador essencial deste crime? Sim, o que provavelmente redundaria em menor número de condenações, inclusive nos casos em que a narrativa das ofendidas sinalizasse a ocorrência de fraude, engodo, compra do assentimento e violência.

O nó górdio da temática está exatamente aqui. Neste patamar podemos entrar numa circularidade discursiva que enverede pelos caminhos do controle policial e de novas possibilidades de uso dos mecanismos de repressão penal ao crime. Também podemos, diferentemente, buscar outra linguagem para o enfrentamento do problema, que seja capaz de reduzir as distorções do discurso criminal dominante.

No livro "Direitos Humanos, democracia e desenvolvimento", Sousa Santos (2013) parte da hegemonia dos direitos como linguagem de dignidade humana para enfocar a

${ }^{123}$ Artigo 5o, caput, da Constituição Federal. 
contradição real de que a maioria da população mundial não é vista como sujeito de direitos humanos, mas como objeto de seus discursos, como registrei no primeiro capítulo. Esse pressuposto é base para a investigação das possibilidades de utilização dos direitos humanos de modo subversivo, na contramão do discurso que reproduz a opressão. A matéria de que se constituem os direitos é feita no trabalho político dos movimentos e organizações sociais, bem como no labor teórico da construção alternativa desses mesmos direitos. No campo dos direitos humanos das mulheres não é diferente, sempre haverá mais de uma narrativa possível e é preciso buscar uma discursividade contra-hegemônica capaz de ir contra as assimetrias de gênero que persistem no pensamento ocidental dominante.

Sartre é quem, no século XX, retoma a visão aristotélica da liberdade incondicional do homem sobre si e no mundo (CHAUí, 2012). Para ele, a liberdade seria para o humano necessidade e fatalidade, por definir a própria humanidade da pessoa. Ou seja: é não apenas o exercício do ato voluntário de escolher, virtude incondicionada que se opõe à necessidade e à contingência da vida - como propugnava Aristóteles —, mas condição de humanidade ${ }^{124}$.

Marilena Chauí (2012, p. 419), numa releitura de Sartre, define a liberdade como “consciência simultânea das circunstâncias existentes e das ações que, suscitadas por tais circunstâncias, nos permitem ultrapassá-las, dando-lhes outro rumo e um novo sentido, que não teriam sem nossa ação" 125 .

Se a liberdade é condição de realização plena das mulheres e o discurso penal que deveria proteger os direitos de todas as mulheres é ambivalente, tendo uma vertente perversa de controle paternalista da migração feminina, é imperativo buscar janelas que permitam reler a questão do tráfico internacional para fins de exploração sexual por uma perspectiva libertadora. Como podemos alterar o curso e o sentido das políticas antitráfico para que elas veiculem menos o discurso dominante andro-cis-heternormativo e passem a se alinhar com um projeto de proteção sincera dos direitos humanos das mulheres?

\footnotetext{
124 “O quietismo é a atitude daqueles que dizem: os outros podem fazer o que eu não posso. A doutrina que lhes estou apresentando é justamente o contrário do quietismo, visto que ela afirma: a realidade não existe a não ser na ação; aliás, vai mais longe ainda, acrescentando: o homem [a mulher] nada mais é [são] do que o seu projeto; só existe[m] na medida em que se realiza[m]; não é [são] nada além do conjunto de seus atos, nada mais que sua vida" (SARTRE, 1970, p. 11).

${ }^{125}$ E prossegue: "A liberdade é a capacidade para darmos um sentido novo ao que parecia fatalidade, transformando a situação de fato numa realidade nova, criada por essa ação. Essa força transformadora, que torna real o que era somente possível e que se achava apenas latente como possibilidade, é o que faz surgir uma obra de arte, uma obra de pensamento, uma ação heroica, um movimento antirracista, uma luta contra a discriminação sexual ou de classe social, uma resistência à tirania e a vitória contra ela. O possível não é pura contingência ou acaso. $\mathrm{O}$ necessário não é fatalidade bruta. $\mathrm{O}$ possível é o que se encontra aberto no coração do necessário e que nossa liberdade agarra para fazer-se liberdade" (CHAUÍ, 2012, p. 422).
} 
Ernst Bloch (2005, p. 100) afirma que "todo o real transcorre com um ainda-não nele contido. Composições significativas da fantasia do sonho diurno não produzem bolhas de sabão: elas abrem janelas e, por trás destas, o mundo do sonho diurno é no mínimo uma possibilidade a que se pode dar forma”. Quais são as possibilidades de linguagem existentes para uma abordagem do tráfico de pessoas e, mais especialmente, para tratar de migração de mulheres e tráfico? Que ferramentas podem nos permitir alcançar patamares mais elevados de proteção, sem deixar de lado os projetos de inclusão social equitativa de todas as mulheres no mundo globalizado?

Para Aníbal Quijano (2002), a globalidade foi inicialmente compreendida como um processo drástico de modificação das relações entre espaço e tempo na subjetividade humana, que passou a identificar, na intensificação dos fluxos de informações, o "apequenamento do mundo" 126 .

Segundo o autor, esse processo foi orientado por um padrão de poder mundial articulado em quatro grandes eixos (QUIJANO, 2002, p. 1): (i) o da colonialidade, compreendida a partir da utilização da ideia de "raça" como "padrão de classificação social básica e dominação social"; (ii) o do capitalismo, que favoreceu uma concentração absurda do controle de recursos por uma minoria de pessoas e alimentou a polarização social extrema entre ricos e pobres; (iii) o do Estado-Nação, como autoridade coletiva e forma hegemônica de organização do poder público; e, (iv) o do eurocentrismo, como padrão dominante de "controle da subjetividade/intersubjetividade, em particular no modo de produzir conhecimento".

Quijano (2002) propõe como estratégia de enfrentamento a esse modelo excludente de implementação de uma modernidade periférica nos países da América Latina o empenho na retomada do controle do trabalho, do sexo, da autoridade coletiva, da subjetividade e, principalmente, do modo de produção do conhecimento.

Enrique Dussel compartilha com Quijano o sentimento de que a América Latina sofre, desde a chegada dos europeus, das imposições decorrentes de sua participação sempre periférica do processo de modernização em que se engajaram os países europeus. Fala, por isso, não em descobrimento, mas em encobrimento da América, no ano de 1492, momento em que a Europa “pôde se confrontar com ‘o outro' e controlá-lo, vencê-lo, violentá-lo; quando

\footnotetext{
${ }^{126}$ Quijano (2002) compreende a globalização como reconcentração da autoridade pública mundial que serve de base para o aprofundamento de tendências básicas do capitalismo e, por isso, tem uma natureza contrarrevolucionária que se faz sentir, por exemplo, em processos de desnacionalização e desdemocratização dos países periféricos.
} 
pôde se definir como um 'ego' descobridor, conquistador, colonizador da Alteridade" (DUSSEL, 1994, p. 8. Tradução livre).

Desde a nominação dos habitantes do Novo Mundo como índios, fruto da impressão preliminar dos europeus de haverem chegado às Índias, Dussel (1994, p. 49) observa que o processo de colonização se traduziu num projeto de controle em larga escala, que impunha "o domínio dos corpos pelo machismo sexual, da cultura, de tipos de trabalhos e de instituições criadas por uma nova burocracia política”.

Modernidade e colonialidade aparecem, sob a perspectiva dos estudos pós-coloniais, como faces de uma mesma moeda. O moderno estaria calcado essencialmente em dois tipos de colonização: a colonização do tempo, a partir da criação das ideias de Idade Média e Renascimento; e a colonização do espaço, pela conquista do Novo Mundo (MIGNOLO, 2009).

Faz parte da reafirmação de uma "modernidade global" o pensamento universalista de progresso, desenvolvimento, salvação e felicidade. Estes seriam, para Walter Mignolo (2009), os componentes de uma retórica de modernidade que, no nível da enunciação e dos sentidos, controla subjetividades, impondo, por exemplo, a educação cristã e laica, criando museus, controlando a produção acadêmica e a informação de massa difundida nos meios de comunicação.

São esses os componentes que também se fazem presentes na gestão e no controle do conhecimento, ilustrados na teologia e na invenção do direito internacional, que “estabeleceram uma ordem geopolítica do conhecimento fundado nos princípios epistêmicos e estéticos europeus que durante séculos legitimaram a desautorização do conhecimento não europeu e dos cânones estéticos não europeus" (MIGNOLO, 2009, p. 49) ${ }^{127}$.

Também Catherine Walsh afirma que a luta pela transformação das relações de poder mundial assentes perpassa o enfrentamento pelo controle de sentidos, pois "nomear também é lutar" (WALSH, s/d, p.1. Tradução livre). É preciso, afirma Walsh, disputar o espaço ocupado pela racionalidade hegemônica dominante no campo das ciências sociais, que é incapaz de

\footnotetext{
127 “O direito internacional se fundou baseando-se em supostos raciais: os 'índios' deviam ser considerados, se humanos, não muito racionais; ainda que dispostos a ser convertidos. A cara da modernidade ficou à vista nos argumentos e pressupostos epistêmicos da teologia jurídica para dizer e determinar quem era o quê. Simultaneamente, a outra cara da colonialidade se ocultava sob o status inferior do inferior inventado. Aqui temos um caso claro de colonialidade como cara oculta necessária e constitutiva da modernidade. A modernidade/colonialidade articula-se aqui a partir de diferenças ontológicas e epistêmicas: os índios são, ontologicamente, seres humanos inferiores e, em consequência, não são plenamente racionais" (MIGNOLO, 2009, p. 46. Tradução livre).
} 
captar "a diversidade e a riqueza da experiência social" e de propor "alternativas epistemológicas contra-hegemônicas que emergem desta experiência” (WALSH, s/d, p.3. Tradução livre).

E assim é que o pensamento descolonial ou pós-colonial se desenvolve, em nível epistêmico, não como um novo paradigma, mas como "Outro" paradigma (SOLER, 2009), que se atenta para a naturalização de hierarquias do sistema de poder mundial ${ }^{128}$, enfrentando "o mito do conhecimento universal fidedigno que disfarça quem fala e sua localização epistêmica geopolítica e corpo-política nas estruturas de poder/conhecimento coloniais" (GROSFOGUEL, 2006, p. 22. Tradução livre).

Os direitos humanos, em sua concepção hegemônica, foram cunhados como linguagem emancipatória herdada do Iluminismo oitocentista e precisam ser identificados como subproduto de um processo histórico de inversão ideológica de valores em favor da manutenção do controle subjetivo, epistêmico, financeiro e político dos países do centro, em favor da perpetuação de modernidades globais que redundam na manutenção de projetos de colonização também globais (MIGNOLO, 2009).

O acolhimento de uma proposta descolonial corresponde, nesse contexto, à desobediência epistêmica. Parte em busca de apropriação da produção de um conhecimento que não se conforme a uma organização racial e discriminatória do gênero feminino. Pede uma articulação em defesa de uma concepção contra-hegemônica dos direitos humanos.

“Eurocentrismo não dá nome a um local geográfico, mas à hegemonia de uma forma de pensar fundamentada no grego e no latim e nas seis línguas europeias e imperiais da modernidade" (MIGNOLO, 2008, p. 301). A modernidade não se define como um lapso histórico inescapável, mas como um feixe de narrativas de mundo, que podem ser transformadas pelo impulso inconformado daquelas que são subalternizadas pelos sistemas de conhecimento e poder assentes. Essa visão permite antever a importância de reescrevermos a

\footnotetext{
${ }^{128}$ Esclarece Soler (2009, p. 53) que: “A novidade da 'colonialidade do poder' e das perspectivas antes apontadas é advertir como a ideia de raça/racismo e aspectos associados a ela como o gênero, a humanidade e a classe se converte em princípios fundamentais de organização, dominação e classificação socionatural, que estruturam as múltiplas hierarquias do sistema e do padrão mundial de poder. Nesse sentido, podemos compreender, por exemplo, como e por que as diferentes formas de trabalho articuladas para a acumulação capitalista em escala mundial são atribuídas de acordo com as hierarquias raciais/classistas; por que a maior parte do trabalho coercitivo (ou precário) é realizado por pessoas não europeias na periferia e o trabalho "em branco" se localiza nos centros capitalistas. Também nos facilita compreender as hierarquias desenvolvimento/subdesenvolvimento, avançado/atrasado, rico/pobre; como e por que os produtos campesinos/populares são subvalorizados em face dos urbanos/capitalistas; ou por que o trabalho feminino/natural é subvalorizado no confronto com o masculino/humano" (Tradução livre).
} 
forma como lidamos hoje com a questão do tráfico internacional de pessoas para fins de exploração sexual.

O Protocolo de Palermo (NAÇÕES UNIDAS, 2003) tem o mérito de trazer à luz diferentes modalidades de subjugação da pessoa humana, no contexto do deslocamento espacial interno ou internacional. É bastante elucidativo ao colocar a ameaça, o uso da força ou outras formas de coação, o rapto, a fraude, o engano, o abuso de autoridade e a compra do consentimento como requisitos objetivos e subjetivos a serem observados quando houver suspeita de tráfico de seres humanos.

Peca, contudo, em pontos nevrálgicos, por sua vagueza e imprecisão. Assim ocorre quando não esclarece ao certo o que seria condição de vulnerabilidade ou exploração. É ainda permeável a abordagens abolicionistas da prostituição por aproximar semanticamente das noções de violência e exploração sexual o termo prostituição.

Trata-se de instrumento normativo internacional que foi cunhado no âmbito da Convenção das Nações Unidas Contra o Crime Organizado Transnacional e, embora veicule uma mensagem de proteção e assistência às vítimas, não se desvincula de uma lógica de criminalização, de repressão de condutas e também de repatriação das pessoas que migraram e foram encontradas em situação de tráfico.

Daí se vê que "a retórica salvacionista da modernidade e a lógica opressiva da colonialidade" (MIGNOLO, 2008b, p. 50) não se destacam uma da outra nas narrativas que o Protocolo de Palermo engendra sobre o tráfico. Cumpre, então, refletir sobre formas de recuperar o controle epistêmico, subjetivo e da autoridade sobre que medidas tomar com relação ao tráfico de pessoas e, em especial, com relação ao tráfico de mulheres para fins de exploração sexual. Falta debater o tema sob uma nova roupagem, com outros termos e outras ferramentas, que sejam mais flexíveis e eficientes que aqueles hoje utilizadas no controle migratório e repressivo penal.

Recordo Elisabeth Bernstein (2010), quando narra o trabalho de cristãs evangélicas e feministas antitráfico de nacionalidade americana que se engajaram no projeto político de "trabalhar pelo resgate", pela salvação, de mulheres migrantes que atuam na prostituição em diferentes países do mundo. Oferecem trabalhos em manufaturas, por exemplo, em troca do abandono da prostituição e da conversão ao modo cristão de vida. Defendem, no mesmo passo, o enrijecimento dos controles criminais da prostituição e das demais formas de 
mercantilização sexual do uso do corpo, no combate à degradação moral ínsita a essas práticas.

Faz parte do controle subjetivo dos países do centro globalizado sobre os países periféricos a retórica salvacionista de uma moral universal, que prega um conceito unívoco do certo e do errado, do degradante, do honrado, e normaliza todas as condutas que não se encaixam neste parâmetro. Esse tipo de estratégia salvacionista tem em sua face oculta não apenas a manutenção do controle da subjetividade das mulheres de todo o mundo, mas se desdobra no controle da autoridade pública, na articulação política e institucional das forças dos países periféricos em torno do tráfico de mulheres como problema de sexualidade e migração.

É marcante o alerta de Caroline Ausserer (2011, p. 112) de que a desconstrução das bases da narrativa sobre uma "crise das fronteiras", na verdade, "desmascara esta como parte de um discurso mais amplo que cria diversos medos para justificar a instalação de regimes mais estritos de migração".

Não devemos ignorar o fato de que, em grande parte das sentenças e dos acórdãos analisados ao longo deste estudo, houve narrativa de fraude, engano, abuso e violência. Portanto, há que se pensar em estratégias de proteção das mulheres que sofrem com esse tipo de violação da liberdade sexual. Nem todas as mulheres consideradas traficadas, estiveram, porém, em situação que pudesse se enquadrar nesse contexto. E é aqui que o recurso a uma discursividade homogênea e universalizante encontra limites que precisam ser debatidos.

A questão é que a esfera dos controles penais e do enrijecimento dos migratórios não parece ser suficientemente permeável a esses matizes, pela própria forma como o processo penal é conduzido no Brasil. Dentro da lógica de julgamento embasado no livre convencimento motivado do magistrado, a participação das vítimas nos casos de tráfico internacional de mulheres para fins de prostituição revela que estas pessoas têm sua fala utilizada como ingrediente que ajuda a engrossar o caldo da condenação penal, mas não é primordial para esse fim.

A subjetividade das vítimas não costuma ser colocada em primeiro plano, mesmo quando a pessoa ofendida se coloca à disposição do juízo, para auxiliar nas investigações. Aliás, inexiste um cuidado em sempre trazer a perspectiva da vítima para o ato decisório.

As sentenças e os acórdãos examinados dão a dimensão de que, enquanto formos debater a temática do tráfico de pessoas para fins de exploração sexual, o campo do direito 
penal será um ambiente limitado, por resvalar por caminhos que, correntemente, reproduzem um marco de segurança a ser aplicado incisivamente sobre as mulheres.

Nos países do centro, se a mulher não for considerada uma vítima de tráfico, deverá ser alcunhada de imigrante ilegal, criminosa, por assim dizer (CASTILHO, 2008). Essa limitação não está ao alcance da Justiça brasileira. Pior é, então, colaborar com o projeto de repatriação que subjaz a Palermo (NAÇÕES UNIDAS, 2003) para enaltecer a importância de recrudescer os controles migratórios, impedindo a saída ou a entrada de mulheres que possam vir a ter o interesse em se prostituir. Isso é render-se ao jogo de manipulação subjetiva e da autoridade que deflui do colonialismo em relação aos países latinos.

A esfera de discursividade penal se identifica, prima facie, como algo que serve à defesa dos direitos humanos das mulheres migrantes. A realidade, porém, é que, nos moldes atuais, ela não contribui para a criação de uma estratégia de agência que tenha a flexibilidade para tratar as diferentes mulheres e, portanto, seus diferentes contextos, de forma adequada, reconhecendo a urgência de que se confira uma cidadania laboral a quem faz do sexo meio de vida, por opção racional e livre.

O discurso repressivo penal contido nas decisões analisadas também inibe a percepção de que o ser migrante é uma categoria social que está embebida de elementos históricos, políticos, sociais, jurídicos e de gênero. É um conceito em disputa e que merece ser reformulado em moldes libertários, não repressivos.

O Judiciário Brasileiro cumpriria melhor o seu papel se, a despeito dos limites que o Código Penal lhe impõe, conferisse centralidade à narrativa das vítimas, reformulasse sua apreensão sobre o fenômeno do tráfico de pessoas pensando a mulher migrante como sujeito de direitos e sujeito de sua própria história; bem como se se desvinculasse da ideia de salvação e dos estereótipos de gênero que utiliza em reafirmação de um modelo de subalternização do feminino.

A busca de novas linguagens para falar sobre tráfico de mulheres perpassa o autoconhecimento de nós, colonizados; a autorização da nossa própria fala; a reflexão crítica sobre os cânones epistêmicos e estéticos dos países do centro globalizado. Pede que sejamos desobedientes em face da colonização do tempo e do espaço e que reinventemos, de forma humanista, o projeto de proteção da mulher dentro de uma narrativa de mundo pluriversal. 


\section{CONCLUSÃO}

Neste estudo de análise qualitativa, propus-me a despir-me dos significados pessoais, para poder alcançar novos significados emergentes da prática discursiva, o que é um desafio. Com isso reconheço que, ainda que tenha tentado extrair das falas dos magistrados os seus significados próprios, o meu olhar é o grande limite da análise do material escolhido.

Busquei respostas para inquietudes que tenho e que não surgem no vazio. Emergem da experiência de viver num corpo de mulher cisgênero, latina, brasileira, parda, jovem. Estão também intrinsecamente relacionadas com a empatia, com o reconhecimento em mim de todas as outras pessoas que comigo compartilham a performance do "ser mulher" numa sociedade que sofre as marcas de uma colonização epistêmica, subjetiva, da autoridade e da economia.

Nós, mulheres, vivemos sob o padrão hegemônico de poder androcêntrico, cisgênero, heteronormativo. Com isso, vivenciamos, nos mais diversos campos da vida e nas diferentes classes sociais, o peso de relações assimétricas de poder que subalternizam o feminino e que se refletem em dispositivos de controle da forma de existir, de se manifestar, de exercer a autonomia e a liberdade sobre nossos corpos.

Não é diferente quando falamos em migração e prostituição, conceitos que se entrelaçam dentro da lógica do que se convencionou chamar de tráfico internacional de mulheres para fins de exploração sexual. Ao longo do estudo, pude observar que, embora as estatísticas globais e os estudos nacionais sobre tráfico de pessoas deem papel de destaque para o tráfico de mulheres e meninas, bem assim para o polo da exploração sexual, esses dados parecem não dar uma dimensão concreta de qual é a magnitude real e o perfil do tráfico internacional de pessoas no Brasil.

Levantam, pelo contrário, suspeitas de imprecisão das estimativas, por dificuldade de harmonização das ferramentas de registro e da compreensão do que seja tráfico de pessoas entre os órgãos que lidam diretamente com esse fenômeno. Parte dessa dissonância está conectada com o limitado marco normativo utilizado pelos órgãos do Sistema de Justiça Criminal: Polícia, Poder Judiciário e Ministério Público.

Os relatórios de que o Brasil dispõe, assim como os relatórios divulgados pelo UNODC, ocultam as cifras de tráfico de pessoas trans, sistemática que se fez presente nas sentenças e nos acórdãos analisados, que não fazem referência a um caso sequer de tráfico de 
mulher transgênero. Também são pouco elucidativos acerca do número real de vítimas e sobre a forma como se estruturam as relações que envolvem a migração internacional nos casos de tráfico de mulheres cisgênero. Não há, ainda, dados estruturados sobre o perfil de vítimas ou ofensores, o que revela um espaço enorme para pesquisas e aprofundamento no tema.

Esse é o pano de fundo sobre o qual me movi ao analisar o conteúdo das decisões proferidas pelo Judiciário Brasileiro. A busca por tramas discursivas sobre o tráfico internacional de mulheres para fins de exploração sexual partiu de um cenário turvo, em que não pude identificar parâmetros objetivos sobre o perfil das vítimas ou a estrutura das relações que permeiam o que se pune como tráfico no país e que pudessem amparar ou justificar certas afirmações, adjetivações, estereotipagens ou associações feitas pelos magistrados.

Por meio do uso de códigos e categorias de análise, identifiquei que havia acórdãos que equiparavam, expressamente, a prostituição à exploração sexual, mesmo não havendo qualquer relato de fraude, engano ou violência. Outras decisões faziam uma aproximação semântica entre prostituição e exploração sexual por meio do uso de expressões como “exploração da prostituição", "obrigou à prostituição", "obrigadas a se prostituírem”. Com isso, colocavam a prostituição como espécie em relação ao gênero exploração sexual, num jogo discursivo de aproximação entre prostituição e violência que reforça o abolicionismo da prostituição, caracterizando a atividade como não trabalho, e atrai consequências danosas para a liberdade das mulheres.

Na prática, esse tipo de associação não diz que toda prostituição é exploração, mas tem o potencial de veicular a mensagem de que a prostituição não é uma atividade compatível com opções livres, autônomas e racionais pelo uso mercantil e recreativo do corpo da mulher cisgênero.

Metade das decisões eram impermeáveis às diferenças entre o auxílio na migração para a prostituição, que abrange o contrabando de migrantes, e o tráfico internacional de mulheres. Intercambiavam um e outro conceitos, em muitos casos, com amparo no argumento de que, pelos dizeres da lei penal brasileira, reiterados na doutrina penal, o consentimento é irrelevante para a caracterização de tráfico internacional de pessoas para fins de exploração sexual.

A prostituição foi associada à degradação moral especialmente quando havia referência ao "trabalho honesto" como sua antítese. Algumas decisões examinadas deixaram antever o papel que o discurso penal desempenha na reafirmação da moral social dominante, 
que condena a mulher que se prostitui aprioristicamente. Nessa categoria, também foi possível observar a argumentação sobre a suposta degradação das mulheres nacionais em projetos migratórios para fins sexuais, veiculada na forma de estereótipos que reproduzem assimetrias de gênero.

Concluí que, em cerca de $65 \%$ das decisões, a mulher supostamente traficada foi retratada como vítima de tráfico de pessoas, o que poderia redundar em acolhimento semântico de sua experiência como algo doloroso. Sem embargo, em um terço dos casos em que a mulher traficada foi considerada vítima, o seu comportamento foi utilizado para reduzir a pena-base do crime, essencialmente nos casos em que já se prostituísse antes ou anuísse com a proposta de migrar para ingressar no mercado do sexo. Aqui, emergiu a noção de uma reprovação latente ao comportamento de quem concorda em se prostituir por opção, a justificar a edificação de um padrão de subalternidade de direitos para a prostituta.

Constatei, não com surpresa, que nem metade das decisões transcrevia a fala da vítima e, mesmo nestes casos, foi recorrente o recurso à fala da mulher supostamente traficada como mera praxe para o relato e a fundamentação da sentença ou do acórdão, ignorando-se a subjetividade daquela voz sobre a eventual ocorrência de fraude, engano, coação, violência ou exploração para fins de condenação.

O retrato geral da pessoa a quem se atribui o sofrimento de ter sido traficada para exploração sexual é, segundo pinta o Judiciário Brasileiro, de "garotas iludidas" ou "pessoas humildes e de pouca instrução", altamente vulneráveis à persuasão ou intimidação.

Surgiu, ainda, a noção de que as mulheres cisgênero que migram já com o intuito de se prostituírem no exterior têm uma imagem cubista picassiana, projetada em três eixos: o que reitera a vulnerabilidade pela pobreza, o da infantilidade ou ingenuidade, e, por último, o da ganância, no qual a desfaçatez e a trapaça são vistas como meios de ascender socialmente. Concentraram-se na mesma figura romantizada e degradada atributos que reforçam a impossibilidade de que a mulher possa, por escolha sua, no contexto das opressões de gênero, raça, cor e classe em que vive, buscar na prostituição um meio legítimo de escapar à circularidade do modelo andro-cis-heteronormativo de sociedade em que está enredada, em busca da realização de seus projetos pessoais de vida.

Outro ponto emergente dos discursos analisados esteve no alinhamento entre a fala do Poder Judiciário e propostas de controle ostensivo da migração feminina e da abolição da prostituição, que se associa à pré-compreensão de que "as mulheres nunca entram livremente 
em relações sexuais fora do 'amor' ou do desejo sexual autônomo” (KEMPADOO, 2005, p. $58)$.

Notei que, no campo das narrativas jurídico-penais, o fato de que se ignore o consentimento da vítima essencializa a realidade do tráfico, impedindo a visibilização nítida do tamanho do problema, por colocar num mesmo cepo situações de restrição da liberdade e aquelas em que, simplesmente, ocorre a migração autônoma para fins de prostituição. Funciona, por outro lado, como um facilitador da prova nos casos em que realmente há engano, fraude ou qualquer forma de violência física ou moral no processo migratório.

É nesse encontro da tentativa de proteção das mulheres com relação à violência sexual - que hoje se dá sobre bases paternalistas - com a necessidade de resguardo do projeto libertador do uso do próprio corpo e do legítimo sonho de migrar que as narrativas repressivopenais demonstram sua limitação intrínseca. A dificuldade está na ambivalência do discurso penal, que acaba resvalando para um controle perverso da migração feminina.

A presente pesquisa me leva a concluir que é preciso buscar outra linguagem para o enfrentamento do problema do tráfico de pessoas, problema este cuja dimensão é ainda desconhecida, mas que sabemos que existe, como demonstra a maior parte das decisões analisadas neste estudo, em que narrativas de fraude, engano, coação, ameaça, exploração e diversas formas de violência estavam presentes.

A liberdade surge como condição de realização plena das mulheres e deve ser um parâmetro para a busca de novas formas de discursar sobre tráfico internacional para fins de exploração sexual. É por isso que, como subproduto desta pesquisa, surge o questionamento de como podemos alterar o curso e o sentido das políticas antitráfico para que elas veiculem menos o discurso dominante andro-cis-heternormativo e passem a se alinhar com um projeto de proteção sincera dos direitos humanos das mulheres. Esse caminho a desbravar pode ser orientado por uma leitura pós-colonial das relações de gênero e do tráfico de pessoas, dando possível base para um aprofundamento investigativo posterior. 


\section{REFERÊNCIAS BIBLIOGRÁFICAS}

ALVES, Raissa R., LIMA, Raquel N. S.; SEABRA, Samira L. Prostituição e Tráfíco de Pessoas. Tribuna do Brasil, Brasília, 26 set 2007. Coluna Direito Achado na Rua, p. 9.

AUSSERER, Caroline. "Controle em nome da proteção": análise do discurso de tráfíco de pessoas como problema de migração. Revista Internacional de Mobilidade Humana. Brasília, ano XIX, n. 37, p.107-123, jul-dez, 2011.

BARDIN, Laurence. Análise de conteúdo. Tradução: Luís Antero Reto e Augusto Pinheiro. Lisboa: Edições 70, 1979.

BARONAS, Roberto L. Efeitos de sentido de pertencimento à análise de discurso. In: FERREIRA, Maria Cristina; INDURSKI, Freda (organização). Análise do discurso no Brasil: mapeando conceitos, confrontando limites. São Carlos: Claraluz, 2007. p. 187-198.

BARTLETT, Katherine T. Métodos jurídicos feministas. In: Métodos feministas en el derecho. Aproximaciones críticas a la jurisprudencia peruana. Lima: Palestra, 2011. p. 19-116.

BRASIL. Câmara dos Deputados. Decreto no. 2.954, de 10 de agosto de 1938. Decreta a execução e o cumprimento da Convenção internacional relativa à repressão do tráfico de mulheres maiores, firmada em Genebra, a 11 de outubro de 1933. Diário Oficial da União, de 10 de agosto de 1938. [S.I.] Camara.leg. Disponível em http://www2.camara.leg.br/legin/fed/decret/1930-1939/decreto-2954-10-agosto-1938-345722publicacaooriginal-1-pe.html. Acesso em: 26 de junho de 2015.

. Câmara dos Deputados. Decreto no. 21.076/1932. Decreta o código eleitoral. [S.I.] Camara.leg. Disponível em http://www2.camara.leg.br/legin/fed/decret/1930-1939/decreto21076-24-fevereiro-1932-507583-norma-pe.html. Acesso em: 5 de fevereiro de 2016.

. Câmara dos Deputados. Projeto de Lei no-. 4.211, de 2012. Regulamenta a atividade das profissionais do sexo (Projeto Gabriela Leite). Deputado Jean Wyllys. [S.I.] Camara.leg. Disponível em: http://www.camara.gov.br/proposicoesWeb/fichadetramitacao?idProposicao $=551899$. Acesso em: 5 de fevereiro de 2016.

. Ministério da Justiça. Relatório Nacional sobre Tráfico de Pessoas: consolidação

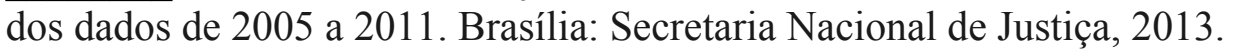

. Ministério da Justiça. Relatório Nacional sobre Tráfico de Pessoas: dados de 2012.

Brasília: Secretaria Nacional de Justiça, 2014. [S.I.] Justiça.mj. Disponível em http://pt.slideshare.net/justicagovbr/2-relatrio-nacional-sobre-trfico-de-pessoas-no-brasil.

Acesso em: 26 de junho de 2015.

Presidência da República. Decreto n⿳⺈.2.740, de 20 de agosto de 1998. Promulga a Convenção Interamericana sobre Tráfico Internacional de Menores, assinada na Cidade do México em 18 de março de 1994. [S.I.] Planalto. Disponível em http://www.planalto.gov.br/ccivil_03/decreto/D2740.htm. Acesso em: 26 de junho de 2015.

Presidência da República. Decreto no. 4.399, de 25 de setembro de 2002. Promulga 
o Estatuto de Roma do Tribunal Penal Internacional. Diário Oficial da União, de 26 de setembro de 2002. [S.I.] Planalto. Disponível em: http://www.planalto.gov.br/ccivil_03/decreto/2002/D4399.htm. Acesso em: 5 de fevereiro de 2016.

Presidência da República. Decreto noo. 5.017, de 12 de março de 2004. Promulga o Protocolo Adicional à Convenção das Nações Unidas contra o Crime Organizado Transnacional Relativo à Prevenção, Repressão e Punição do Tráfico de Pessoas, em Especial Mulheres e Crianças. Diário Oficial da União, de 15 de março de 2004. [S.I.] Planalto. Disponível em http://www.planalto.gov.br/ccivil_03/_ato2004-2006/2004/decreto/d5017.htm. Acesso em: 5 de fevereiro de 2016.

Presidência da República. Decreto no . 5.948, de 26 de outubro de 2006. Aprova a Política Nacional de Enfrentamento ao Tráfico de Pessoas e institui Grupo de Trabalho Interministerial com o objetivo de elaborar proposta do Plano Nacional de Enfrentamento ao Tráfico de Pessoas - PNETP. Diário Oficial da União, de 27 de outubro de 2006. [S.I.] Planalto. Disponível em: http://www.planalto.gov.br/ccivil_03/ato20042006/2006/Decreto/D5948.htm. Acesso em: 5 de fevereiro de 2016.

. Presidência da República. Decreto-Lei no. 2.848, de 7 de dezembro de 1940 (Código Penal Brasileiro). Diário Oficial da União, de 31 de dezembro de 1940. [S.I.] Planalto. Disponível em: http://www.planalto.gov.br/ccivil_03/decreto-lei/Del2848.htm. Acesso em: 5 de fevereiro de 2016.

Presidência da República. Decreto-Lei no. 3.689, de 3 de outubro de 1941 (Código de Processo Penal). Diário Oficial da União, de 13 de outubro de 1941, retificado em 24 de outubro de 1941. Planalto. Disponível: http://www.planalto.gov.br/ccivil 03/decretolei/Del3689.htm. Acesso em: 5 de fevereiro de 2016.

. Presidência da República. Decreto n⿳o . 23.812, de 30 de Janeiro de 1934. Promulga a Convenção para repressão do tráfico de mulheres e crianças, firmada em Genebra, a 30 de setembro de 1921 . [S.I.] Planalto. Disponível em http://www.oas.org/juridico/mla/pt/bra/pt_bra_convencao_internacional_repressao_trafico_m ulheres_criancas.pdf. Acesso em: 26 de junho de 2015.

Presidência da República. Lei no․ 8.089, de 13 julho de 1990 (Estatuto da Criança e do Adolescente - ECA). Dispõe sobre o Estatuto da Criança e do Adolescente e dá outras providências. Diário Oficial da União, de 16 de julho de 1990, retificado em 27 de setembro 1990. [S.I.] Planalto. Disponível em: http://www.planalto.gov.br/ccivil_03/LEIS/L8069.htm. Acesso em: 5 de fevereiro de 2016.

. Senado Federal. Decreto no. 46.981, de 8 de outubro de 1959. Promulga, com o respectivo Protocolo Final, a Convenção para a repressão do tráfico de pessoas e do lenocínio, concluída em Lake Success Nova York, em 21 de março de 1950, e assinada pelo Brasil em 5 de outubro de 1951. [S.I.] Senado.leg. Disponível em http://legis.senado.gov.br/legislacao/ListaPublicacoes.action?id=112661. Acesso em: 26 de junho de 2015.

Senado Federal. Projeto de Lei do Senado no. 236, de 2012. Reforma do Código Penal. Senador José Sarney. [S.I.] Senado.leg. Disponível em: http://www25.senado.leg.br/web/atividade/materias/-/materia/106404. Acesso em: 5 de 
fevereiro de 2016.

. Senado Federal. Projeto de Lei do Senado no. 479, de 2012. Dispõe sobre prevenção e punição ao tráfico interno e internacional de pessoas, bem como sobre medidas de proteção às vítimas. CPI Tráfico Nacional e Internacional de Pessoas no Brasil (2011). [S.I.] Senado.leg. Disponível em: http://www25.senado.leg.br/web/atividade/materias//materia/110044. Acesso em: 5 de fevereiro de 2016.

BAUMAN, Zigmunt. Identidade. Tradução: Carlos Alberto Medeiros. Rio de Janeiro: Zahar, 2005.

BERNSTEIN, Elisabeth. The sexual politics of the "new abolitionism". Brown university and differences: a journal of feminist cultural studies, v. 18, n. 3, 2007.

. O significado da compra: desejo, demanda e o comércio do sexo. Cadernos Pagu, n. 31, p. 315-362, julho-dezembro, 2008.

BLOCH, Ernst. O princípio esperança. Tradução: Nélio Schneider. Rio de Janeiro: EdUERJ Contraponto, 2005. v. 1.

BUTLER, Judith. El marxismo y lo meramente cultural. (Artigo originalmente apresentado em uma das sessões plenárias sobre "Locations of Power", que ocorreu durante a conferência intitulada "Rethinking Marxism", celebrada em Amherst, Massachusetts, em dezembro de 1996). [S.I.] Disponível em http://campusmoodle.proed.unc.edu.ar/file.php/265/Biblioteca/judith_butler_el_marxismo_y_ lo meramente cultural.pdf. Acesso em: 24 de junho de 2015.

CAPPELlE, Mônica C. A.; MELO, Marlene C. O. L.; GONÇALVES, Carlos A. Análise de conteúdo e análise de discurso nas ciências sociais. In: Organizações rurais e agroindustriais, vol. 5, n. 1. Lavras, 2003. [S.I.] Disponível em: http://revista.dae.ufla.br/index.php/ora/index. Acesso em: 23 de fevereiro de 2016.

CASTILHO, Ela Wiecko V. de. Tráfico de pessoas: da Convenção de Genebra ao Protocolo de Palermo. In: Plano nacional de enfrentamento ao tráfico de pessoas. Brasília: Ministério da Justiça, 2008.

- Exploração sexual no tráfico de pessoas: (in)definição. In: Cadernos Temáticos sobre Tráfico de Pessoas. Volume 1: Conceito e Tipologias de Exploração. 1a ed. Brasília: Ministério da Justiça, Secretaria Nacional de Justiça, Coordenação de Enfrentamento ao Tráfico de Pessoas, 2015.

. Problematizando o Conceito de Vulnerabilidade para o Tráfico Internacional de Pessoas. In: Tráfico de pessoas: uma abordagem para os direitos humanos. Brasília: Secretaria Nacional de Justiça do Ministério da Justiça, 2013.

CHARAUDEAU, Patrick; MAINGUENEAU, Dominique. Dicionário de análise do discurso. Tradução: Fabiana Komesu. 3a ed. São Paulo: Contexto, 2014.

CHAUÍ, Marilena. Convite à filosofia. São Paulo: Ática, 2012.

COOK, Rebecca J. Rebecca Cook: entrevistada por Debora Diniz. Pensamento contemporâneo, 7. Revisão e Tradução: Ana Terra Mejia Munhoz; Revisão Jurídica, Beatriz 
Galli e Carmem Campos. Rio de Janeiro: UERJ, 2012.

CRESWELL, John W. Projeto de pesquisa: métodos qualitativo, quantitativo e misto. Tradução: Magda Lopes. Porto Alegre: Artmed, 2010.

CRESWELL, John W.; PLANO CARK, Vicki L. Pesquisa de métodos mistos. Tradução: Magda Lopes. 2ª ed. Porto Alegre: Penso, 2013, Cap. 1. p. 19-31.

DAICH, Deborah. Abolicionismo o reglamentarismo? Aportes de la antropologia feminista para el debate local sobre la prostitución. Revista Runa, UBA, XXXIII, p. 71-84, 2012.

DUSSEL, Enrique. 1492 El encubrimiento del Otro. Hacia el origen del "mito de la Modernidad". La Paz: Plural editores - Facultad de Humanidades y Ciencias de la Educación - UMSA, 1994.

FOUCAULT, Michel. Microfisica do Poder. Organização, introdução e revisão técnica: Roberto Machado. 25a ed. São Paulo: Graal, 2012.

GIL, Antonio C. Métodos e técnicas de pesquisa social. 4⿳亠丷⿵冂丶 ed. São Paulo: Atlas, 1994.

GORENSTEIN, Fabiana. Da concepção menorista à proteção integral: oscilações de discurso na CPMI da exploração sexual de crianças e adolescentes. Dissertação de mestrado apresentada na Universidade de Brasília. Brasília, 2009.

GROSFOGUEL, Ramón. La descolonización de la economía política y los estudios postcoloniales: transmodernidad, pensamiento fronterizo y colonialidad global. Tabula rasa, $\mathrm{n}$. 4, jan. - jun., 2006.

HARAWAY, Donna. J. Manifesto ciborgue: ciência, tecnologia e feminismo-socialista no final do século XX. In: HARAWAY, Donna J. Antropologia do ciborgue: as vertigens do pós-humano. Organização e tradução: Tomaz Tadeu. 2- ed. Belo Horizonte: Autêntica Editora, 2009. p. 33-118.

HARDING, Sandra. The science question in feminism. Ithaca: Cornell University Press, 1986.

KEMPADOO, Kamala. Mudando o debate sobre o tráfico de mulheres. Tradução: Plínio Dentzien. Cadernos Pagu, 25, p. 55-78, jul. - dez., 2005.

KUHN, Thomas. A Estrutura das Revoluções Cientificas. Tradução: Beatriz V. Boeira e Nelson Boeira. São Paulo: Editora Perspectiva, 1975.

LAVILLE, Christian; DIONNE, Jean. A construção do saber: manual de metodologia da pesquisa em ciências humanas. Tradução: Heloísa Monteiro e Francisco Settineri. Porto Alegre: Artmed; Belo Horizonte: Editora UFMG, 1999. p. 214-230.

LYRA FILHO, Roberto. O que é direito? São Paulo: Brasiliense, 1982.

. A Nova Escola Jurídica Brasileira. Revista Notícia do Direito brasileiro. Brasília, n.o 7, p. 497-507, 2000.

LIMA, Raquel N. S.; SEABRA, Samira L. Tráfico de pessoas: uma revisão dos conceitos sob 
uma perspectiva de gênero e as atuais ações de combate e controle. In: SOUSA, Nair H. B. de; MIRANDA, Adriana A.; GORENSTEIN, Fabiana (organização). Desafios e perspectivas para o enfrentamento ao tráfico de pessoas no Brasil. Brasília: Ministério da Justiça, Secretaria Nacional de Justiça, Coordenação de Enfrentamento ao Tráfico de Pessoas, 2011.

MACHADO, Lia Zanotta. Perspectivas em confronto: relações de gênero ou patriarcado contemporâneo? Série Antropologia, n. 284. Departamento de Antropologia, UnB: 2000.

MAINGUENAU, Dominique. Novas tendências em análise do discurso. 3- ed. Tradução: Freda Indurski. Campinas: Pontes, 1997.

MAQUEDA ABREU, María Luisa. ¿Qué passa con la prostitución de las mujeres? Algunas reflexiones desde un discurso de los derechos. s/d. [S.I.] Olvidos.es Disponível em: http://www.olvidos.es/app/webroot/pdf/maqueda.pdf. Acesso em: 12 de fevereiro de 2016.

MENDONÇA, Laís M. S. Imigração e trabalho: luta por reconhecimento dos imigrantes no Brasil. Análise da participação social dos imigrantes na 1- Conferência Municipal de Políticas para Imigrantes de São Paulo. Dissertação de mestrado apresentada na Universidade de Brasília. Brasília, 2014.

MENDONÇA, Talitha S. N. Prostituição: trabalho ou tráfico? A criação da vítima de tráfico de pessoas. Dissertação de mestrado apresentada na Universidade de Brasília. Brasília, 2014.

MIGNOLO, Walter D. Desobediência epistêmica: a opção descolonial e o significado de identidade em política. Tradução: Ângela Lopes Norte. Cadernos de Letras da UFF. Dossiê: literatura, língua e identidade, n. 34, p. 287-324, 2008a.

Hermenéutica de la democracia: el pensamento de los limites y la diferencia colonial. Tabula Rasa, n. 9, jul. - dez., p. 39-60, 2008 b.

. La colonialidad: la cara oculta de la modernidad. In. Catalog of museum exhibit: Modernologies, Manual. Museu de Arte Moderna de Barcelona. (Tradução: em espanhol de "Coloniality: The Darker Side of Modernity") p. 39-49, dez., 2009. [S.I.] Disponível em: http://www.macba.es/PDFs/walter_mignolo_modernologies_cas.pdf. Acesso em: 14 de fevereiro de 2016.

MINAYO, Maria Cecília S.; MINAYO-GÓMEZ, Carlos. Difíceis e possíveis relações entre métodos quantitativos e qualitativos nos estudos de problemas de saúde. In: GOLDENBERG, Paulete; MARSIGLIA, Regina M. G.; GOMES, Mara H. A. (organização). O Clássico e o Novo: tendências, objetos e abordagens em ciências sociais e saúde. Rio de Janeiro: FIOCRUZ, p. 117-142, 2003.

MINAYO, Maria Cecília S.; SANCHES, Odécio. Quantitativo-qualitativo: oposição ou complementaridade? Artigo. Caderno de Saúde Pública, Rio de Janeiro, 9 (3): 239-262, jul. set., 1993.

MISKOLCI, Richard. A teoria queer e a questão das diferenças: por uma analítica da normalização. $\mathrm{s} / \mathrm{d}$. [S.I.] Disponível em: http://alb.com.br/arquivomorto/edicoes anteriores/anais16/prog pdf/prog03 01.pdf. Acesso em: 15 de fevereiro de 2015.

NAÇÕES UNIDAS. An introduction to human trafficking: vulnerability, impact and action. 
New York: United Nations, 2008. [S.I.] UNODC. Disponível em https://www.unodc.org/documents/humantrafficking/An Introduction to Human Trafficking - Background Paper.pdf. Acesso em: 24 de junho de 2015.

Assembleia Geral. Informe del Comité Especial encargado de elaborar una convención contra la delincuencia organizada transnacional sobre la labor de sus períodos de sesiones primero a 11‥ Adición. Notas interpretativas para los documentos oficiales (travaux préparatoires) de la negociación de la Convención de las Naciones Unidas contra la Delincuencia Organizada Transnacional y sus protocolos. A/55/383/Add. 1, de 3 de novembro de 2000, 22 p. In: Travaux Préparatoires for de Organized Crime Convention and protocols. [S.I.] UNODC. Disponível em www.unodc.org. Acesso em: 25 de junho de 2015.

- Convenção das Nações Unidas contra o Crime Organizado Transnacional. Aprovada pela Assembleia-Geral da ONU em 15 de novembro de 2000. Em vigor desde 29 de setembro de 2003. [S.I.] UNODC. Disponível em https://www.unodc.org/lpo-brazil/pt/crime/marco-legal.html. Acesso em: 26 de junho de 2015.

Convenção para a supressão do tráfico de pessoas e da exploração da prostituição de outrem (Lake Success, 1949). [S.I.] Disponível em http://bo.io.gov.mo/bo/i/99/13/resoluar31.asp\#ptg. Acesso em: 26 de junho de 2015.

. Convenção sobre a Eliminação de Todas as Formas de Discriminação contra a Mulher (CEDAW). Aprovada pela Organização das Nações Unidas em 1979, tendo entrado em vigor em 1981. [S.I.] Unifem. Disponível em http://www.unifem.org.br/005/00502001.asp?ttCD_CHAVE=8466. Acesso em: 26 de junho de 2015.

2009.

Global Report on Trafficking in Persons 2009. Nações Unidas: Viena,

Global Report on Trafficking in Persons 2012. Nações Unidas: Nova Iorque, 2012 (United Nations publication, Sales n. E. 13 v. 1).

. Global Report on Trafficking in Persons 2014. Nações Unidas: Nova Iorque, 2014 (United Nations publication, Sales n. E. 14 v. 10).

. Protocolo Adicional à Convenção das Nações Unidas contra o Crime Organizado Transnacional (Protocolo de Palermo). Aprovado pela resolução da AssembleiaGeral 55/25. Em vigor desde 25 de dezembro de 2003.

. Protocolo contra o Contrabando de Migrantes por via Terrestre, Marítima e Aérea (Protocolo dos Migrantes). Aprovado pela resolução da Assembleia-Geral 55/25. Em vigor desde 25 de dezembro de 2003.

UNODC. Documento temático. O papel do consentimento no protocolo sobre tráfico de pesssoas. Viena: Nações Unidas, 2014.

. UNODC. Human trafficking case law database. [S.I.] UNODC. Disponível em https://www.unodc.org/cld/index.jspx. Acesso em: 18 de fevereiro de 2016. UNODC. Issue paper. Abuse of a position of vulnerability and other 
"means" with the definition of trafficking in persons. Nações Unidas: Viena, 2013.

UNODC. Issue paper. The concept of "exploitation" in the trafficking in persons protocol. Nações Unidas: Viena, 2015.

NARZETTI, Claudiana. As linhas de análise do discurso na França dos anos 60-70. Revista virtual de Letras, v. 2, n. 02/2010, p. 51-70. ISSN 2176-9125. [S.I.] Disponível em http://www.revlet.com.br/artigos/52.pdf. Acesso em: 11 de junho de 2015.

OLIVEIRA, Eugênio P. de. Curso de Processo Penal. 16-eㅁ. São Paulo: Atlas, 2012.

OLIVEIRA, João M. de; AMANCIO, Lívia. Teorias feministas e representações sociais: desafios dos conhecimentos situados para a psicologia social. Rev. Estud. Fem. 2006, v. 14, n.3, p. 597-615. [S.I.] Disponível em: http://dx.doi.org/10.1590/S0104026X2006000300002. Acesso em: 8 de agosto de 2015.

ORGANIZAÇÃO INTERNACIONAL DO TRABALHO. Convenção 29, de 10 de junho de 1930, sobre o trabalho forçado ou obrigatório. [S.I.] OIT. Disponível em: http://www.oit.org.br/sites/all/forced labour/oit/convencoes/conv 29.pdf. Acesso em: 26 de junho de 2015.

de 1953. Disponível em: http://www.direitoshumanos.usp.br/index.php/OITOrganiza\%C3\%A7\%C3\%A3o-Internacional-do-Trabalho/convencao-relativa-a-escravatura1953.html. Acesso em: 24 de junho de 2015.

Convenção Suplementar sobre a

Abolição da Escravatura, do Tráfico de Escravos e das Instituições e Práticas Análogas à $\begin{array}{llllll}\text { Escravatura, } & \text { de } & 1956 . & \text { [S.I.] } & \text { OIT. } & \text { Disponível }\end{array}$ http://www.direitoshumanos.usp.br/index.php/OIT-Organiza\%C3\%A7\%C3\%A3oInternacional-do-Trabalho/convencao-suplementar-sobre-abolicao-da-escravatura-do-traficode-escravos-e-das-instituicoes-e-praticas-analogas-a-escravatura-1956.html. Acesso em: 24 de junho de 2015.

ORLANDI, Eni P. Análise de discurso: princípios e procedimentos. 7a ed. Campinas: Pontes, 2007.

PATEMAN, Carole. O que há de errado com a prostituição? In. PATEMAN, C. O contrato sexual. Tradução: Marta Avancini. São Paulo: Paz e Terra, 1993. Cap. 7.

PÊCHEUX, Michel. Semântica e discurso: uma crítica à informação do óbvio. Campinas: Editora Unicamp, 1988.

PISCITELLI, Adriana G. Entre as máfias e a ajuda: a construção de conhecimento sobre tráfico de pessoas. Cadernos Pagu. Unicamp, n. 31, p. 29-63, 2008.

. Feminismos e prostituição no Brasil: uma leitura a partir da antropologia feminista. Cuadernos de antropologia social, n. 36, p. 11-31, 2012.

PISCITELLI, Adriana G.; VASCONCELOS, Marcia. Dossiê gênero no tráfico de pessoas. Apresentação. Cadernos Pagu. Unicamp, n. 31, p. 9-28, 2008. 
QUIJANO, Aníbal. Colonialidade, poder, globalização e democracia. Revista novos rumos. Ano 17, n. 37, 2002.

RAGO, Margareth. As mulheres na historiografia brasileira. In: SILVA, Zélia L. da (organização). Cultura histórica em debate. São Paulo: UNESP, 1995.

ROCHA, Décio; DEUSDARÁ, Bruno. Análise de conteúdo e análise do discurso: aproximações e afastamentos na (re)construção de uma trajetória. Álea: Estudos Neolatinos, v. 7, n. 2, jul-dez, 2005. [S.I.] Disponível em http://www.scielo.br/scielo.php?pid=S1517106X2005000200010\&script=sci_arttext\&tlng=ES. Acesso em: 11 de jun. de 2015.

SAFFIOTI, Heleieth I. B. A mulher na sociedade de classes: Mito e realidade. Petrópolis: Vozes, 1979.

SAMPIERE, Roberto H.; COLLADO, Carlos F.; LUCIO, María del Pilar B. Metodologia de pesquisa. Tradução: Daisy Vaz de Moraes. 5ª ed. São Paulo: McGraw-Hill Ed., 2013.

SARTRE, Jean Paul. O existencialismo é um humanismo. Tradução: Rita Correia Guedes. Fonte: Paris: Les Éditions Nagel, 1970.

SOLER, Juan Carlos V. La perspectiva decolonial y sus posibles contribuciones a la construcción de Otra economía. Otra economía, v. III, n. 4, 1ํsemestre/2009.

SOUSA SANTOS, Boaventura de. Direitos humanos, democracia e desenvolvimento. São Paulo: Cortez, 2013.

SOUSA JUNIOR, José Geraldo de. Direito como liberdade: O Direito Achado na Rua. Experiências populares emancipatórias de criação do direito. Tese de doutorado apresentada na Universidade de Brasília. Brasília, 2008.

Que Judiciário na Democracia? In: SOUSA JUNIOR, José Geraldo de. Ideias para a cidadania e para a justiça. Porto Alegre: Sergio Antonio Fabris, p. 13-17, 2008.

WALSH, Catherine. Estudios (inter)culturales en clave de-colonial. Tabula Rasa, s/d. Artigo apresentado no Congresso "Estudios Culturales en las Américas: compromiso, colaboración, transformación”, organizado pela Universidade da Califórnia, Davis/Pontifícia Universidade Javeriana, Bogotá, 26-28 de out., 2009. 


\section{APÊNDICES}

Apêndice A - Conjunto de decisões constantes da base de dados do UNODC até dezembro de 2015

Apêndice B - Decisões incluídas na análise qualitativa de dados

Apêndice C - Decisões excluídas da análise qualitativa de dados

Apêndice D - Categorias analíticas

Apêndice E - Confirmação da hipótese de que o discurso jurídico-penal é utilizado de forma potencialmente prejudicial aos direitos das mulheres 


\section{Apêndice A}

\begin{tabular}{|c|c|c|c|c|}
\hline \multicolumn{5}{|c|}{ DECISÕES CONTIDAS NO CASE LAW DATABASE ATÉ DEZEMBRO DE 2015} \\
\hline DOC. & CLASSE & NÚMERO & ORIGEM & REFERÊNCIA \\
\hline $\begin{array}{c}\text { DOC. } \\
1\end{array}$ & Sentença & 2006.30.0000.0871-5 & $\begin{array}{c}\text { Justiça Federal, Subseção } \\
\text { Judiciária do Estado do } \\
\text { Acre }\end{array}$ & BRA 028 \\
\hline $\begin{array}{c}\text { DOC. } \\
2\end{array}$ & Sentença & 2006.33.00.005669-9 & $\begin{array}{c}\text { Justiça Federal, Subseção } \\
\text { Judiciária do Estado da } \\
\text { Bahia }\end{array}$ & BRA 031 \\
\hline $\begin{array}{c}\text { DOC. } \\
3\end{array}$ & Sentença & 1999.71.03.001519-4 & $\begin{array}{c}\text { Justiça Federal, Subseção } \\
\text { Judiciária do Estado do } \\
\text { Rio Grande do Sul }\end{array}$ & BRA 073 \\
\hline $\begin{array}{c}\text { DOC. } \\
4\end{array}$ & $\begin{array}{l}\text { Apelação } \\
\text { Criminal }\end{array}$ & $1999.71 .03 .001519-4$ & $\begin{array}{c}\text { Tribunal Regional Federal } \\
\text { da 4- Região }\end{array}$ & BRA 073 \\
\hline $\begin{array}{l}\text { DOC. } \\
5\end{array}$ & Sentença & 2004.61.2000.1211-9 & $\begin{array}{c}\text { Justiça Federal, Subseção } \\
\text { Judiciária do Estado de } \\
\text { São Paulo }\end{array}$ & BRA 049 \\
\hline $\begin{array}{l}\text { DOC. } \\
\quad 6\end{array}$ & Sentença & $97.13 .01451-0$ & $\begin{array}{c}\text { Justiça Federal, Subseção } \\
\text { Judiciária do Estado do } \\
\text { Rio Grande do Sul }\end{array}$ & BRA 034 \\
\hline $\begin{array}{c}\text { DOC. } \\
7 \\
\end{array}$ & $\begin{array}{l}\text { Apelação } \\
\text { Criminal } \\
\end{array}$ & $2003.60 .04 .000915-4$ & $\begin{array}{c}\text { Tribunal Regional Federal } \\
\text { da 3a Região }\end{array}$ & BRA 024 \\
\hline $\begin{array}{l}\text { DOC. } \\
\quad 8\end{array}$ & Sentença & \begin{tabular}{|c|}
$0008821-69.2011 .403 .6181$ \\
$\quad$ (Processo 0011221- \\
27.2009 .4 .03 .6181 )
\end{tabular} & Origem não informada. & BRA 071 \\
\hline $\begin{array}{c}\text { DOC. } \\
9\end{array}$ & Sentença & $2001.38 .03 .002448-8$ & $\begin{array}{c}\text { Justiça Federal, Subseção } \\
\text { Judiciária do Estado de } \\
\text { Minas Gerais }\end{array}$ & BRA 072 \\
\hline $\begin{array}{c}\text { DOC. } \\
10\end{array}$ & Sentença & $2005.83 .0000 .6886-8$ & $\begin{array}{c}\text { Justiça Federal, Subseção } \\
\text { Judiciária do Estado de } \\
\text { Pernambuco } \\
\end{array}$ & BRA 064 \\
\hline $\begin{array}{l}\text { DOC. } \\
11\end{array}$ & Sentença & $2009.84 .00 .005367-8$ & $\begin{array}{c}\text { Justiça Federal, Subseção } \\
\text { Judiciária do Estado do } \\
\text { Rio Grande do Norte }\end{array}$ & BRA 060 \\
\hline $\begin{array}{c}\text { DOC. } \\
12\end{array}$ & Sentença & 6682.72 .2010 .405 .8300 & Origem não informada. & BRA 057 \\
\hline $\begin{array}{c}\text { DOC. } \\
13\end{array}$ & Sentença & $2001.71 .03 .001661-4$ & $\begin{array}{c}\text { Justiça Federal, Subseção } \\
\text { Judiciária do Estado do } \\
\text { Rio Grande do Sul }\end{array}$ & BRA 043 \\
\hline $\begin{array}{l}\text { DOC. } \\
14\end{array}$ & Sentença & $2005.70 .03 .005598-2$ & $\begin{array}{c}\text { Justiça Federal, Subseção } \\
\text { Judiciária do Estado do } \\
\text { Paraná } \\
\end{array}$ & BRA 040 \\
\hline $\begin{array}{c}\text { DOC. } \\
15\end{array}$ & Sentença & $2005.72 .09 .000609-8$ & $\begin{array}{c}\text { Justiça Federal, Subseção } \\
\text { Judiciária do Estado de }\end{array}$ & BRA 016 \\
\hline
\end{tabular}




\begin{tabular}{|c|c|c|c|c|}
\hline & & & Santa Catarina & \\
\hline $\begin{array}{c}\text { DOC. } \\
16 \\
\end{array}$ & $\begin{array}{l}\text { Apelação } \\
\text { Criminal } \\
\end{array}$ & $1389-24.2002 .4 .03 .6113$ & $\begin{array}{c}\text { Tribunal Regional Federal } \\
\text { da 3- Região }\end{array}$ & BRA 019 \\
\hline $\begin{array}{c}\text { DOC. } \\
17 \\
\end{array}$ & $\begin{array}{l}\text { Apelação } \\
\text { Criminal } \\
\end{array}$ & $2005.03 .99 .009508-0$ & $\begin{array}{c}\text { Tribunal Regional Federal } \\
\text { da 3- Região }\end{array}$ & BRA 069 \\
\hline $\begin{array}{c}\text { DOC. } \\
18\end{array}$ & Sentença & $2004.38 .03 .009328-4$ & $\begin{array}{c}\text { Justiça Federal, Subseção } \\
\text { Judiciária do Estado de } \\
\text { Minas Gerais } \\
\end{array}$ & BRA 001 \\
\hline $\begin{array}{c}\text { DOC. } \\
19 \\
\end{array}$ & $\begin{array}{l}\text { Apelação } \\
\text { Criminal }\end{array}$ & $\begin{array}{c}0001703- \\
58.2007 .4 .03 .6124 \\
\end{array}$ & $\begin{array}{c}\text { Tribunal Regional Federal } \\
\text { da 3- Região }\end{array}$ & BRA 020 \\
\hline $\begin{array}{c}\text { DOC. } \\
20\end{array}$ & Sentença & 896379.2002 .4 .05 .8300 & Origem não informada. & BRA 066 \\
\hline $\begin{array}{c}\text { DOC. } \\
21\end{array}$ & Sentença & $89.0040455-5$ & $\begin{array}{c}\text { Justiça Federal, Subseção } \\
\text { Judiciária do Estado de } \\
\text { São Paulo }\end{array}$ & BRA 015 \\
\hline $\begin{array}{c}\text { DOC. } \\
22\end{array}$ & $\begin{array}{l}\text { Apelação } \\
\text { Criminal }\end{array}$ & $96.03 .087722-0$ & $\begin{array}{c}\text { Tribunal Regional Federal } \\
\text { da 3- Região }\end{array}$ & BRA 032 \\
\hline $\begin{array}{c}\text { DOC. } \\
23\end{array}$ & Sentença & $2001.81 .00 .016360-1$ & $\begin{array}{c}\text { Justiça Federal, Subseção } \\
\text { Judiciária do Estado do } \\
\text { Ceará } \\
\end{array}$ & BRA 007 \\
\hline $\begin{array}{c}\text { DOC. } \\
24 \\
\end{array}$ & $\begin{array}{l}\text { Apelação } \\
\text { Criminal } \\
\end{array}$ & $\begin{array}{c}0007379- \\
88.2000 .4 .03 .6105 \\
\end{array}$ & $\begin{array}{c}\text { Tribunal Regional Federal } \\
\text { da 33- Região }\end{array}$ & BRA 022 \\
\hline $\begin{array}{l}\text { DOC. } \\
25\end{array}$ & Sentença & $2001.83 .00 .007512-0$ & $\begin{array}{c}\text { Justiça Federal, Subseção } \\
\text { Judiciária do Estado de } \\
\text { Pernambuco } \\
\end{array}$ & BRA 074 \\
\hline $\begin{array}{c}\text { DOC. } \\
26 \\
\end{array}$ & $\begin{array}{l}\text { Apelação } \\
\text { Criminal } \\
\end{array}$ & $2001.83 .00 .007512-0$ & $\begin{array}{c}\begin{array}{c}\text { Tribunal Regional Federal } \\
\text { da 5- Região }\end{array} \\
\end{array}$ & BRA 074 \\
\hline $\begin{array}{c}\text { DOC. } \\
27\end{array}$ & Sentença & $98.21262-0$ & $\begin{array}{c}\text { Justiça Federal, Subseção } \\
\text { Judiciária do Estado do } \\
\text { Ceará }\end{array}$ & BRA 003 \\
\hline $\begin{array}{c}\text { DOC. } \\
28 \\
\end{array}$ & Sentença & $1979-29.2004 .4 .05 .8100$ & Origem não informada. & BRA 005 \\
\hline $\begin{array}{c}\text { DOC. } \\
29\end{array}$ & Sentença & $\begin{array}{c}0006689- \\
60.2007 .4 .05 .8400\end{array}$ & $\begin{array}{c}\text { Justiça Federal, Subseção } \\
\text { Judiciária do Estado do } \\
\text { Rio Grande do Norte } \\
\end{array}$ & BRA 063 \\
\hline $\begin{array}{c}\text { DOC. } \\
30\end{array}$ & Sentença & $2005.70 .00 .032242-8$ & $\begin{array}{c}\text { Justiça Federal, Subseção } \\
\text { Judiciária do Estado do } \\
\text { Paraná } \\
\end{array}$ & BRA 033 \\
\hline $\begin{array}{c}\text { DOC. } \\
31\end{array}$ & Sentença & 2004.81.00.0118889-0 & $\begin{array}{c}\text { Justiça Federal, Subseção } \\
\text { Judiciária do Estado do } \\
\text { Ceará } \\
\end{array}$ & BRA 004 \\
\hline $\begin{array}{c}\text { DOC. } \\
32\end{array}$ & Sentença & $2005.81 .00 .003813-6$ & $\begin{array}{c}\text { Justiça Federal, Subseção } \\
\text { Judiciária do Estado do } \\
\text { Ceará } \\
\end{array}$ & BRA 056 \\
\hline DOC. & Apelação & $2004.81 .00 .018889-0$ & Tribunal Regional Federal & BRA 056 \\
\hline
\end{tabular}




\begin{tabular}{|c|c|c|c|c|}
\hline 33 & Criminal & & da 5- Região & \\
\hline $\begin{array}{c}\text { DOC. } \\
34\end{array}$ & $\begin{array}{l}\text { Apelação } \\
\text { Criminal }\end{array}$ & $2005.61 .19 .004841-3$ & $\begin{array}{c}\text { Tribunal Regional Federal } \\
\text { da 3a - Região }\end{array}$ & BRA 021 \\
\hline $\begin{array}{c}\text { DOC. } \\
35\end{array}$ & $\begin{array}{l}\text { Apelação } \\
\text { Criminal }\end{array}$ & $2004.83 .00 .007499-2$ & $\begin{array}{c}\text { Tribunal Regional Federal } \\
\text { da 5- Região }\end{array}$ & BRA 065 \\
\hline $\begin{array}{l}\text { DOC. } \\
36\end{array}$ & Sentença & $2004.83 .00 .007499-2$ & $\begin{array}{c}\text { Justiça Federal, Subseção } \\
\text { Judiciária do Estado de } \\
\text { Pernambuco } \\
\end{array}$ & BRA 065 \\
\hline $\begin{array}{c}\text { DOC. } \\
37\end{array}$ & $\begin{array}{l}\text { Habeas } \\
\text { Corpus }\end{array}$ & $2004.03 .00022133-0$ & $\begin{array}{c}\text { Tribunal Regional Federal } \\
\text { da 3- Região }\end{array}$ & $\begin{array}{l}\text { BRA } 030 \mathrm{E} \\
\quad 075\end{array}$ \\
\hline $\begin{array}{c}\text { DOC. } \\
38\end{array}$ & $\begin{array}{l}\text { Habeas } \\
\text { Corpus }\end{array}$ & $2009.03 .00 .014160-5$ & $\begin{array}{c}\text { Tribunal Regional Federal } \\
\text { da 3- Região }\end{array}$ & $\begin{array}{l}\text { BRA } 027 \mathrm{E} \\
054\end{array}$ \\
\hline $\begin{array}{c}\text { DOC. } \\
39\end{array}$ & $\begin{array}{l}\text { Habeas } \\
\text { Corpus }\end{array}$ & $2007.85 .00 .032809-9$ & $\begin{array}{l}\text { Tribunal Regional Federal } \\
\text { da 5- Região (dentro do } \\
\text { Pr. 2008.05.00.101562-0) }\end{array}$ & BRA 044 \\
\hline $\begin{array}{c}\text { DOC. } \\
40\end{array}$ & $\begin{array}{l}\text { Habeas } \\
\text { Corpus }\end{array}$ & $2007.05 .00 .035891-2$ & $\begin{array}{l}\text { Tribunal Regional Federal } \\
\text { da 5a Região (dentro do } \\
\text { Pr. 2008.05.00.101562-0) }\end{array}$ & BRA 044 \\
\hline $\begin{array}{c}\text { DOC. } \\
41\end{array}$ & $\begin{array}{l}\text { Habeas } \\
\text { Corpus }\end{array}$ & $2008.05 .00 .101562-0$ & $\begin{array}{c}\text { Tribunal Regional Federal } \\
\text { da 5- Região }\end{array}$ & BRA 044 \\
\hline $\begin{array}{c}\text { DOC. } \\
42\end{array}$ & Sentença & $\begin{array}{c}0010012- \\
44.2005 .4 .05 .8400\end{array}$ & $\begin{array}{c}\text { Justiça Federal, Subseção } \\
\text { Judiciária do Estado do } \\
\text { Rio Grande do Norte } \\
\text { (Dentro do } \\
\text { 2008.05.00.101562-0) }\end{array}$ & BRA 044 \\
\hline $\begin{array}{c}\text { DOC. } \\
43\end{array}$ & $\begin{array}{l}\text { Habeas } \\
\text { Corpus }\end{array}$ & $2007.03 .00 .020742-5$ & $\begin{array}{c}\text { Tribunal Regional Federal } \\
\text { da 3- Região }\end{array}$ & $\begin{array}{l}\text { BRA } 029 \mathrm{E} \\
061 \\
\end{array}$ \\
\hline $\begin{array}{c}\text { DOC. } \\
44 \\
\end{array}$ & $\begin{array}{l}\text { Habeas } \\
\text { Corpus }\end{array}$ & $2006.05 .00 .062316-0$ & $\begin{array}{c}\text { Tribunal Regional Federal } \\
\text { da 5- Região }\end{array}$ & BRA 051 \\
\hline $\begin{array}{c}\text { DOC. } \\
45 \\
\end{array}$ & $\begin{array}{l}\text { Habeas } \\
\text { Corpus }\end{array}$ & $2006.05 .00 .28010-4$ & $\begin{array}{c}\text { Tribunal Regional Federal } \\
\text { da 5- Região }\end{array}$ & BRA 055 \\
\hline $\begin{array}{c}\text { DOC. } \\
46\end{array}$ & $\begin{array}{l}\text { Habeas } \\
\text { Corpus }\end{array}$ & $2005.05 .00 .050441-5$ & $\begin{array}{c}\text { Tribunal Regional Federal } \\
\text { da 5- Região }\end{array}$ & BRA 059 \\
\hline $\begin{array}{c}\text { DOC. } \\
47\end{array}$ & $\begin{array}{l}\text { Habeas } \\
\text { Corpus }\end{array}$ & $2005.05 .00 .050376-9$ & $\begin{array}{c}\text { Tribunal Regional Federal } \\
\text { da 5- Região }\end{array}$ & BRA 067 \\
\hline $\begin{array}{c}\text { DOC. } \\
48 \\
\end{array}$ & $\begin{array}{l}\text { Habeas } \\
\text { Corpus }\end{array}$ & $2005.05 .00 .050439-7$ & $\begin{array}{c}\text { Tribunal Regional Federal } \\
\text { da 5- Região }\end{array}$ & BRA 070 \\
\hline $\begin{array}{c}\text { DOC. } \\
49\end{array}$ & $\begin{array}{l}\text { Habeas } \\
\text { Corpus }\end{array}$ & $2007.05 .00 .025014-1$ & $\begin{array}{c}\text { Tribunal Regional Federal } \\
\text { da 5- Região }\end{array}$ & BRA 050 \\
\hline $\begin{array}{c}\text { DOC. } \\
50\end{array}$ & $\begin{array}{l}\text { Habeas } \\
\text { Corpus }\end{array}$ & $2007.05 .00 .024317-3$ & $\begin{array}{c}\text { Tribunal Regional Federal } \\
\text { da 5- Região }\end{array}$ & BRA 012 \\
\hline $\begin{array}{c}\text { DOC. } \\
51 \\
\end{array}$ & $\begin{array}{l}\text { Habeas } \\
\text { Corpus }\end{array}$ & $2007.05 .00 .029423-5$ & $\begin{array}{c}\text { Tribunal Regional Federal } \\
\text { da 5- Região }\end{array}$ & BRA 009 \\
\hline $\begin{array}{c}\text { DOC. } \\
52\end{array}$ & $\begin{array}{l}\text { Habeas } \\
\text { Corpus }\end{array}$ & $2008.03 .00 .020091-5$ & $\begin{array}{c}\text { Tribunal Regional Federal } \\
\text { da 3- Região }\end{array}$ & BRA 062 \\
\hline
\end{tabular}




\begin{tabular}{|c|c|c|c|c|}
\hline $\begin{array}{c}\text { DOC. } \\
53\end{array}$ & $\begin{array}{l}\text { Habeas } \\
\text { Corpus }\end{array}$ & 6554.23 .2010 .4 .05 .0000 & $\begin{array}{c}\text { Tribunal Regional Federal } \\
\text { da } 5 \text { - Região }\end{array}$ & BRA 045 \\
\hline $\begin{array}{c}\text { DOC. } \\
54 \\
\end{array}$ & $\begin{array}{l}\text { Habeas } \\
\text { Corpus }\end{array}$ & $2007.05 .00 .088769-6$ & $\begin{array}{c}\text { Tribunal Regional Federal } \\
\text { da 5 - Região }\end{array}$ & BRA 046 \\
\hline $\begin{array}{c}\text { DOC. } \\
55 \\
\end{array}$ & $\begin{array}{l}\text { Habeas } \\
\text { Corpus }\end{array}$ & $2006.05 .00 .028008-6$ & $\begin{array}{c}\text { Tribunal Regional Federal } \\
\text { da 5- Região }\end{array}$ & BRA 068 \\
\hline $\begin{array}{l}\text { DOC. } \\
56\end{array}$ & $\begin{array}{l}\text { Habeas } \\
\text { Corpus }\end{array}$ & $2009.03 .00 .011161-3$ & $\begin{array}{c}\text { Tribunal Regional Federal } \\
\text { da 3a- Região }\end{array}$ & BRA 023 \\
\hline $\begin{array}{c}\text { DOC. } \\
57\end{array}$ & $\begin{array}{l}\text { Habeas } \\
\text { Corpus }\end{array}$ & $8002-31.2010 .4 .05 .0000$ & $\begin{array}{c}\text { Tribunal Regional Federal } \\
\text { da 5- Região }\end{array}$ & BRA 035 \\
\hline $\begin{array}{c}\text { DOC. } \\
58\end{array}$ & $\begin{array}{l}\text { Habeas } \\
\text { Corpus }\end{array}$ & $2007.05 .00 .024422-0$ & $\begin{array}{c}\text { Tribunal Regional Federal } \\
\text { da 5a - Região }\end{array}$ & BRA 011 \\
\hline $\begin{array}{c}\text { DOC. } \\
59\end{array}$ & $\begin{array}{l}\text { Revisão } \\
\text { Criminal } \\
\end{array}$ & 420540.2011 .4 .04 .0000 & $\begin{array}{c}\text { Tribunal Regional Federal } \\
\text { da 4a - Região }\end{array}$ & BRA 039 \\
\hline $\begin{array}{c}\text { DOC. } \\
60 \\
\end{array}$ & $\begin{array}{l}\text { Revisão } \\
\text { Criminal } \\
\end{array}$ & $17108-17.2010 .4 .05 .0000$ & $\begin{array}{c}\text { Tribunal Regional Federal } \\
\text { da 5- Região }\end{array}$ & $\begin{array}{c}\text { BRA } 041 \mathrm{e} \\
\text { BRA } 010\end{array}$ \\
\hline $\begin{array}{c}\text { DOC. } \\
61\end{array}$ & $\begin{array}{l}\text { Recurso em } \\
\text { Sentido } \\
\text { Estrito }\end{array}$ & 6196.78.2010.4.05.8400 & $\begin{array}{c}\text { Tribunal Regional Federal } \\
\text { da 5- Região }\end{array}$ & BRA 036 \\
\hline $\begin{array}{c}\text { DOC. } \\
62\end{array}$ & $\begin{array}{c}\text { Recurso em } \\
\text { Sentido } \\
\text { Estrito } \\
\end{array}$ & $11221.27 .2009 .4 .03618-1$ & $\begin{array}{c}\text { Tribunal Regional Federal } \\
\text { da 3- Região }\end{array}$ & BRA 026 \\
\hline $\begin{array}{c}\text { DOC. } \\
63\end{array}$ & $\begin{array}{c}\text { Embargos de } \\
\text { Declaração } \\
\text { nos autos da } \\
\text { Apelação } \\
\text { Criminal }\end{array}$ & $2005.03 .99 .009508-0$ & $\begin{array}{c}\text { Tribunal Regional Federal } \\
\text { da 3- Região }\end{array}$ & BRA 069 \\
\hline $\begin{array}{c}\text { DOC. } \\
64\end{array}$ & $\begin{array}{c}\text { Embargos de } \\
\text { Declaração } \\
\text { nos autos da } \\
\text { Apelação } \\
\text { Criminal }\end{array}$ & $2004.61 .06 .00 .4897-4$ & $\begin{array}{c}\text { Tribunal Regional Federal } \\
\text { da 3- Região }\end{array}$ & $\begin{array}{l}\text { BRA } 025 \mathrm{E} \\
\quad 053\end{array}$ \\
\hline $\begin{array}{l}\text { DOC. } \\
65\end{array}$ & $\begin{array}{c}\text { Termo de } \\
\text { Audiência no } \\
\text { Processo }\end{array}$ & $2008.84 .0000 .3092-3$ & $\begin{array}{c}\text { Justiça Federal, Subseção } \\
\text { Judiciária do Estado do } \\
\text { Rio Grande do Norte }\end{array}$ & BRA 052 \\
\hline $\begin{array}{l}\text { DOC. } \\
66\end{array}$ & $\begin{array}{c}\text { Sentença em } \\
\text { Inquérito } \\
\text { Policial } \\
\end{array}$ & $2000.61 .07 .000474-3$ & $\begin{array}{c}\text { Justiça Federal, Subseção } \\
\text { Judiciária do Estado de } \\
\text { São Paulo } \\
\end{array}$ & BRA 017 \\
\hline $\begin{array}{l}\text { DOC. } \\
67\end{array}$ & Sentença & 98.21939-0 & $\begin{array}{c}\text { Justiça Federal, Subseção } \\
\text { Judiciária do Estado do } \\
\text { Ceará }\end{array}$ & BRA 006 \\
\hline $\begin{array}{c}\text { DOC. } \\
68\end{array}$ & $\begin{array}{l}\text { Apelação } \\
\text { Criminal } \\
\end{array}$ & $2002.83 .0000 .8963-9$ & $\begin{array}{c}\text { Tribunal Regional Federal } \\
\text { da 5a- Região }\end{array}$ & BRA 058 \\
\hline $\begin{array}{c}\text { DOC. } \\
69\end{array}$ & Sentença & 4159.81 .2005 .4 .05 .8100 & $\begin{array}{c}\text { Justiça Federal, Subseção } \\
\text { Judiciária do Estado do } \\
\text { Ceará }\end{array}$ & BRA 018 \\
\hline
\end{tabular}




\begin{tabular}{|c|c|c|c|c|}
\hline $\begin{array}{c}\text { DOC. } \\
70\end{array}$ & Sentença & $97.01 .04597-1$ & $\begin{array}{c}\text { Justiça Federal, Subseção } \\
\text { Judiciária do Estado de } \\
\text { São Paulo }\end{array}$ & BRA 047 \\
\hline $\begin{array}{c}\text { DOC. } \\
71\end{array}$ & Sentença & $4447-11.2005 .4 .05 .8300$ & $\begin{array}{c}\text { Justiça Federal, Subseção } \\
\text { Judiciária do Estado de } \\
\text { Pernambuco }\end{array}$ & BRA 014 \\
\hline $\begin{array}{c}\text { DOC. } \\
72\end{array}$ & Sentença & $97.13 .01651-3$ & $\begin{array}{c}\text { Justiça Federal, Subseção } \\
\text { Judiciária do Estado do } \\
\text { Rio Grande do Sul }\end{array}$ & BRA 042 \\
\hline $\begin{array}{c}\text { DOC. } \\
73\end{array}$ & Sentença & $2006.721 .00 .01111-9$ & $\begin{array}{c}\text { Justiça Federal, Subseção } \\
\text { Judiciária do Estado de } \\
\text { Santa Catarina } \\
\end{array}$ & BRA 037 \\
\hline $\begin{array}{c}\text { DOC. } \\
74\end{array}$ & Sentença & $2000.37 .0000 .2913-2$ & $\begin{array}{c}\text { Justiça Federal, Subseção } \\
\text { Judiciária do Estado do } \\
\text { Maranhão } \\
\end{array}$ & BRA 002 \\
\hline $\begin{array}{c}\text { DOC. } \\
75\end{array}$ & Sentença & $2003.83 .0000 .2077-2$ & $\begin{array}{c}\text { Justiça Federal, Subseção } \\
\text { Judiciária do Estado de } \\
\text { Pernambuco } \\
\end{array}$ & BRA 013 \\
\hline $\begin{array}{c}\text { DOC. } \\
76\end{array}$ & Sentença & $1999.61 .8100 .6981-4$ & $\begin{array}{c}\text { Justiça Federal, Subseção } \\
\text { Judiciária do Estado de } \\
\text { Santa Catarina } \\
\end{array}$ & BRA 038 \\
\hline $\begin{array}{c}\text { DOC. } \\
77\end{array}$ & Sentença & $2007.61 .8100 .1663-8$ & $\begin{array}{c}\text { Justiça Federal, Subseção } \\
\text { Judiciária do Estado de } \\
\text { São Paulo } \\
\end{array}$ & BRA 048 \\
\hline $\begin{array}{c}\text { DOC. } \\
78 \\
\end{array}$ & Acórdão & 7002.74.0949-9 & Origem não informada. & BRA 077 \\
\hline $\begin{array}{c}\text { DOC. } \\
79\end{array}$ & $\begin{array}{l}\text { Apelação } \\
\text { Criminal }\end{array}$ & $2008.5001 .008495-8$ & $\begin{array}{c}\text { Justiça Federal, Subseção } \\
\text { Judiciária do Estado do } \\
\text { Espírito Santo } \\
\end{array}$ & BRA 078 \\
\hline $\begin{array}{c}\text { DOC. } \\
80\end{array}$ & Sentença & 090/2.07.0001774-0 & $\begin{array}{c}\text { Justiça Federal, Subseção } \\
\text { Judiciária do Estado do } \\
\text { Rio Grande do Sul } \\
\end{array}$ & BRA 076 \\
\hline $\begin{array}{c}\text { DOC. } \\
81\end{array}$ & $\begin{array}{l}\text { Apelação } \\
\text { Criminal }\end{array}$ & $2004.81 .00 .006158-0$ & $\begin{array}{c}\text { Tribunal Regional Federal } \\
\text { da } 4^{\mathrm{a}} \text { - Região }\end{array}$ & BRA 008 \\
\hline
\end{tabular}




\section{Apêndice B}

\begin{tabular}{|c|c|c|c|c|}
\hline \multicolumn{5}{|c|}{ DECISÕES INCLUIIDAS NA ANÁLISE QUALITATIVA DE DADOS } \\
\hline DOC. & CLASSE & NÚMERO & ORIGEM & REFERÊNCIA \\
\hline $\begin{array}{l}\text { DOC. } \\
1\end{array}$ & Sentença & $2006.30 .0000 .0871-5$ & $\begin{array}{c}\text { Justiça Federal, } \\
\text { Subseção Judiciária do } \\
\text { Estado do Acre }\end{array}$ & BRA 028 \\
\hline $\begin{array}{l}\text { DOC. } \\
2\end{array}$ & Sentença & $2006.33 .00 .005669-9$ & $\begin{array}{c}\text { Justiça Federal, } \\
\text { Subseção Judiciária do } \\
\text { Estado da Bahia } \\
\end{array}$ & BRA 031 \\
\hline $\begin{array}{l}\text { DOC. } \\
3\end{array}$ & Sentença & $1999.71 .03 .001519-4$ & $\begin{array}{c}\text { Justiça Federal, } \\
\text { Subseção Judiciária do } \\
\text { Estado do Rio Grande } \\
\text { do Sul }\end{array}$ & BRA 073 \\
\hline $\begin{array}{c}\text { DOC. } \\
4\end{array}$ & $\begin{array}{l}\text { Apelação } \\
\text { Criminal }\end{array}$ & $1999.71 .03 .001519-4$ & $\begin{array}{c}\text { Tribunal Regional } \\
\text { Federal da 4- Região }\end{array}$ & BRA 073 \\
\hline $\begin{array}{l}\text { DOC. } \\
5\end{array}$ & Sentença & 2004.61.2000.1211-9 & $\begin{array}{c}\text { Justiça Federal, } \\
\text { Subseção Judiciária do } \\
\text { Estado de São Paulo }\end{array}$ & BRA 049 \\
\hline $\begin{array}{l}\text { DOC. } \\
6\end{array}$ & Sentença & $97.13 .01451-0$ & $\begin{array}{c}\text { Justiça Federal, } \\
\text { Subseção Judiciária do } \\
\text { Estado do Rio Grande } \\
\text { do Sul } \\
\end{array}$ & BRA 034 \\
\hline $\begin{array}{c}\text { DOC. } \\
7 \\
\end{array}$ & $\begin{array}{l}\text { Apelação } \\
\text { Criminal } \\
\end{array}$ & $2003.60 .04 .000915-4$ & $\begin{array}{c}\text { Tribunal Regional } \\
\text { Federal da 3- Região }\end{array}$ & BRA 024 \\
\hline $\begin{array}{l}\text { DOC. } \\
8\end{array}$ & Sentença & $\begin{array}{c}\text { 0008821-69.2011.403.6181 } \\
\text { (Processo 0011221- } \\
27.2009 .4 .03 .6181 \text { ) }\end{array}$ & Origem não informada. & BRA 071 \\
\hline $\begin{array}{l}\text { DOC. } \\
9\end{array}$ & Sentença & $2001.38 .03 .002448-8$ & $\begin{array}{c}\text { Justiça Federal, } \\
\text { Subseção Judiciária do } \\
\text { Estado de Minas Gerais }\end{array}$ & BRA 072 \\
\hline $\begin{array}{l}\text { DOC. } \\
10\end{array}$ & Sentença & $2005.83 .0000 .6886-8$ & $\begin{array}{c}\text { Justiça Federal, } \\
\text { Subseção Judiciária do } \\
\text { Estado de Pernambuco } \\
\end{array}$ & BRA 064 \\
\hline $\begin{array}{c}\text { DOC. } \\
11\end{array}$ & Sentença & $2009.84 .00 .005367-8$ & $\begin{array}{c}\text { Justiça Federal, } \\
\text { Subseção Judiciária do } \\
\text { Estado do Rio Grande } \\
\text { do Norte } \\
\end{array}$ & BRA 060 \\
\hline $\begin{array}{c}\text { DOC. } \\
12 \\
\end{array}$ & Sentença & 6682.72 .2010 .405 .8300 & Origem não informada. & BRA 057 \\
\hline $\begin{array}{c}\text { DOC. } \\
13\end{array}$ & Sentença & $2001.71 .03 .001661-4$ & $\begin{array}{c}\text { Justiça Federal, } \\
\text { Subseção Judiciária do } \\
\text { Estado do Rio Grande } \\
\text { do Sul } \\
\end{array}$ & BRA 043 \\
\hline DOC. & Sentença & $2005.70 .03 .005598-2$ & Justiça Federal, & BRA 040 \\
\hline
\end{tabular}




\begin{tabular}{|c|c|c|c|c|}
\hline 14 & & & $\begin{array}{l}\text { Subseção Judiciária do } \\
\text { Estado do Paraná }\end{array}$ & \\
\hline $\begin{array}{l}\text { DOC. } \\
15\end{array}$ & Sentença & 2005.72.09.000609-8 & $\begin{array}{c}\text { Justiça Federal, } \\
\text { Subseção Judiciária do } \\
\text { Estado de Santa } \\
\text { Catarina }\end{array}$ & BRA 016 \\
\hline $\begin{array}{c}\text { DOC. } \\
16\end{array}$ & $\begin{array}{l}\text { Apelação } \\
\text { Criminal }\end{array}$ & $1389-24.2002 .4 .03 .6113$ & $\begin{array}{c}\text { Tribunal Regional } \\
\text { Federal da } 3 \text { a Região }\end{array}$ & BRA 019 \\
\hline $\begin{array}{c}\text { DOC. } \\
17\end{array}$ & $\begin{array}{l}\text { Apelação } \\
\text { Criminal }\end{array}$ & $2005.03 .99 .009508-0$ & $\begin{array}{c}\text { Tribunal Regional } \\
\text { Federal da 3- Região }\end{array}$ & BRA 069 \\
\hline $\begin{array}{l}\text { DOC. } \\
18\end{array}$ & Sentença & $2004.38 .03 .009328-4$ & $\begin{array}{c}\text { Justiça Federal, } \\
\text { Subseção Judiciária do } \\
\text { Estado de Minas Gerais }\end{array}$ & BRA 001 \\
\hline $\begin{array}{c}\text { DOC. } \\
19\end{array}$ & $\begin{array}{l}\text { Apelação } \\
\text { Criminal }\end{array}$ & 0001703-58.2007.4.03.6124 & $\begin{array}{c}\text { Tribunal Regional } \\
\text { Federal da 3a Região }\end{array}$ & BRA 020 \\
\hline $\begin{array}{c}\text { DOC. } \\
20\end{array}$ & Sentença & 896379.2002 .4 .05 .8300 & Origem não informada. & BRA 066 \\
\hline $\begin{array}{c}\text { DOC. } \\
21\end{array}$ & Sentença & $89.0040455-5$ & $\begin{array}{c}\text { Justiça Federal, } \\
\text { Subseção Judiciária do } \\
\text { Estado de São Paulo }\end{array}$ & BRA 015 \\
\hline $\begin{array}{c}\text { DOC. } \\
22\end{array}$ & $\begin{array}{l}\text { Apelação } \\
\text { Criminal }\end{array}$ & $96.03 .087722-0$ & $\begin{array}{c}\text { Tribunal Regional } \\
\text { Federal da 3a Região }\end{array}$ & BRA 032 \\
\hline $\begin{array}{c}\text { DOC. } \\
23\end{array}$ & Sentença & $2001.81 .00 .016360-1$ & $\begin{array}{c}\text { Justiça Federal, } \\
\text { Subseção Judiciária do } \\
\text { Estado do Ceará }\end{array}$ & BRA 007 \\
\hline $\begin{array}{c}\text { DOC. } \\
24\end{array}$ & $\begin{array}{l}\text { Apelação } \\
\text { Criminal }\end{array}$ & 0007379-88.2000.4.03.6105 & $\begin{array}{c}\text { Tribunal Regional } \\
\text { Federal da 3- Região }\end{array}$ & BRA 022 \\
\hline $\begin{array}{l}\text { DOC. } \\
25\end{array}$ & Sentença & $2001.83 .00 .007512-0$ & $\begin{array}{l}\text { Justiça Federal, } \\
\text { Subseção Judiciária do } \\
\text { Estado de Pernambuco }\end{array}$ & BRA 074 \\
\hline $\begin{array}{c}\text { DOC. } \\
26\end{array}$ & $\begin{array}{l}\text { Apelação } \\
\text { Criminal }\end{array}$ & $2001.83 .00 .007512-0$ & $\begin{array}{c}\text { Tribunal Regional } \\
\text { Federal da 5- Região }\end{array}$ & BRA 074 \\
\hline $\begin{array}{l}\text { DOC. } \\
27\end{array}$ & Sentença & $98.21262-0$ & $\begin{array}{c}\text { Justiça Federal, } \\
\text { Subseção Judiciária do } \\
\text { Estado do Ceará } \\
\end{array}$ & BRA 003 \\
\hline $\begin{array}{c}\text { DOC. } \\
28\end{array}$ & Sentença & $1979-29.2004 .4 .05 .8100$ & Origem não informada. & BRA 005 \\
\hline $\begin{array}{l}\text { DOC. } \\
29\end{array}$ & Sentença & 0006689-60.2007.4.05.8400 & $\begin{array}{c}\text { Justiça Federal, } \\
\text { Subseção Judiciária do } \\
\text { Estado do Rio Grande } \\
\text { do Norte }\end{array}$ & BRA 063 \\
\hline $\begin{array}{l}\text { DOC. } \\
30\end{array}$ & Sentença & $2005.70 .00 .032242-8$ & $\begin{array}{c}\text { Justiça Federal, } \\
\text { Subseção Judiciária do } \\
\text { Estado do Paraná }\end{array}$ & BRA 033 \\
\hline DOC. & Sentença & 2004.81.00.0118889-0 & Justiça Federal, & BRA 004 \\
\hline
\end{tabular}




\begin{tabular}{|c|c|c|c|c|}
\hline 31 & & $\begin{array}{c}\text { Subseção Judiciária do } \\
\text { Estado do Ceará }\end{array}$ & \\
\hline $\begin{array}{c}\text { DOC. } \\
32\end{array}$ & Sentença & $2005.81 .00 .003813-6$ & $\begin{array}{c}\text { Justiça Federal, } \\
\text { Subseção Judiciária do } \\
\text { Estado do Ceará }\end{array}$ & BRA 056 \\
\hline $\begin{array}{c}\text { DOC. } \\
33\end{array}$ & $\begin{array}{c}\text { Apelação } \\
\text { Criminal }\end{array}$ & $2004.81 .00 .018889-0$ & $\begin{array}{c}\text { Tribunal Regional } \\
\text { Federal da 5- Região }\end{array}$ & BRA 056 \\
\hline $\begin{array}{c}\text { DOC. } \\
34\end{array}$ & $\begin{array}{c}\text { Apelação } \\
\text { Criminal }\end{array}$ & $2005.61 .19 .004841-3$ & $\begin{array}{c}\text { Tribunal Regional } \\
\text { Federal da 3- Região }\end{array}$ & BRA 021 \\
\hline $\begin{array}{c}\text { DOC. } \\
35\end{array}$ & $\begin{array}{c}\text { Apelação } \\
\text { Criminal }\end{array}$ & $2004.83 .00 .007499-2$ & $\begin{array}{c}\text { Tribunal Regional } \\
\text { Federal da 5- Região }\end{array}$ & BRA 065 \\
\hline $\begin{array}{c}\text { DOC. } \\
36\end{array}$ & Sentença & $2004.83 .00 .007499-2$ & $\begin{array}{c}\text { Justiça Federal, } \\
\text { Subseção Judiciária do } \\
\text { Estado de Pernambuco }\end{array}$ & BRA 065 \\
\hline
\end{tabular}


Apêndice C

\begin{tabular}{|c|c|c|c|c|}
\hline \multicolumn{5}{|c|}{ DECISÕES EXCLUÍDAS DA ANÁLISE QUALITATIVA DE DADOS } \\
\hline DOC. & CLASSE & NÚMERO & ORIGEM & REFERÊNCIA \\
\hline $\begin{array}{l}\text { DOC. } \\
37\end{array}$ & Habeas Corpus & $2004.03 .00022133-0$ & $\begin{array}{c}\text { Tribunal Regional Federal } \\
\text { da 3- Região }\end{array}$ & BRA 030 E 075 \\
\hline $\begin{array}{c}\text { DOC. } \\
38\end{array}$ & Habeas Corpus & $2009.03 .00 .014160-5$ & $\begin{array}{c}\text { Tribunal Regional Federal } \\
\text { da 3- Região }\end{array}$ & BRA 027 E 054 \\
\hline $\begin{array}{l}\text { DOC. } \\
39\end{array}$ & Habeas Corpus & $2007.85 .00 .032809-9$ & $\begin{array}{c}\text { Tribunal Regional Federal } \\
\text { da 5- Região (Dentro do } \\
\text { 2008.05.00.101562-0) }\end{array}$ & BRA 044 \\
\hline $\begin{array}{l}\text { DOC. } \\
40\end{array}$ & Habeas Corpus & $2007.05 .00 .035891-2$ & \begin{tabular}{|c|} 
Tribunal Regional Federal \\
da 5a Região (dentro do Pr. \\
2008.05.00.101562-0)
\end{tabular} & BRA 044 \\
\hline $\begin{array}{c}\text { DOC. } \\
41\end{array}$ & Habeas Corpus & $2008.05 .00 .101562-0$ & $\begin{array}{c}\text { Tribunal Regional Federal } \\
\text { da 5- Região }\end{array}$ & BRA 044 \\
\hline $\begin{array}{l}\text { DOC. } \\
42\end{array}$ & Sentença & $\begin{array}{c}0010012- \\
44.2005 .4 .05 .8400\end{array}$ & $\begin{array}{c}\text { Justiça Federal, Subseção } \\
\text { Judiciária do Estado do } \\
\text { Rio Grande do Norte } \\
\text { (dentro do Pr. } \\
\text { 2008.05.00.101562-0) }\end{array}$ & BRA 044 \\
\hline $\begin{array}{c}\text { DOC. } \\
43\end{array}$ & Habeas Corpus & $2007.03 .00 .020742-5$ & $\begin{array}{c}\text { Tribunal Regional Federal } \\
\text { da 3- Região }\end{array}$ & BRA 029 E 061 \\
\hline $\begin{array}{c}\text { DOC. } \\
44\end{array}$ & Habeas Corpus & $2006.05 .00 .062316-0$ & $\begin{array}{l}\text { Tribunal Regional Federal } \\
\text { da 5- Região }\end{array}$ & BRA 051 \\
\hline $\begin{array}{c}\text { DOC. } \\
45\end{array}$ & Habeas Corpus & $2006.05 .00 .28010-4$ & $\begin{array}{c}\text { Tribunal Regional Federal } \\
\text { da 5- Região }\end{array}$ & BRA 055 \\
\hline $\begin{array}{c}\text { DOC. } \\
46\end{array}$ & Habeas Corpus & $2005.05 .00 .050441-5$ & $\begin{array}{c}\text { Tribunal Regional Federal } \\
\text { da 5- Região }\end{array}$ & BRA 059 \\
\hline $\begin{array}{c}\text { DOC. } \\
47\end{array}$ & Habeas Corpus & $2005.05 .00 .050376-9$ & $\begin{array}{c}\text { Tribunal Regional Federal } \\
\text { da 5- Região }\end{array}$ & BRA 067 \\
\hline $\begin{array}{c}\text { DOC. } \\
48\end{array}$ & Habeas Corpus & $2005.05 .00 .050439-7$ & $\begin{array}{c}\text { Tribunal Regional Federal } \\
\text { da 5- Região }\end{array}$ & BRA 070 \\
\hline $\begin{array}{c}\text { DOC. } \\
49\end{array}$ & Habeas Corpus & $2007.05 .00 .025014-1$ & $\begin{array}{c}\text { Tribunal Regional Federal } \\
\text { da 5- Região }\end{array}$ & BRA 050 \\
\hline $\begin{array}{c}\text { DOC. } \\
50 \\
\end{array}$ & Habeas Corpus & $2007.05 .00 .024317-3$ & $\begin{array}{c}\text { Tribunal Regional Federal } \\
\text { da 5- Região }\end{array}$ & BRA 012 \\
\hline $\begin{array}{c}\text { DOC. } \\
51\end{array}$ & Habeas Corpus & $2007.05 .00 .029423-5$ & $\begin{array}{c}\text { Tribunal Regional Federal } \\
\text { da 5a Região }\end{array}$ & BRA 009 \\
\hline $\begin{array}{c}\text { DOC. } \\
52\end{array}$ & Habeas Corpus & $2008.03 .00 .020091-5$ & $\begin{array}{c}\text { Tribunal Regional Federal } \\
\text { da 3- Região }\end{array}$ & BRA 062 \\
\hline $\begin{array}{c}\text { DOC. } \\
53\end{array}$ & Habeas Corpus & 6554.23 .2010 .4 .05 .0000 & $\begin{array}{c}\text { Tribunal Regional Federal } \\
\text { da 5- Região }\end{array}$ & BRA 045 \\
\hline
\end{tabular}




\begin{tabular}{|c|c|c|c|c|}
\hline $\begin{array}{c}\text { DOC. } \\
54\end{array}$ & Habeas Corpus & $2007.05 .00 .088769-6$ & $\begin{array}{l}\text { Tribunal Regional Federal } \\
\text { da 5- Região }\end{array}$ & BRA 046 \\
\hline $\begin{array}{c}\text { DOC. } \\
55\end{array}$ & Habeas Corpus & $2006.05 .00 .028008-6$ & $\begin{array}{c}\text { Tribunal Regional Federal } \\
\text { da 5- Região }\end{array}$ & BRA 068 \\
\hline $\begin{array}{c}\text { DOC. } \\
56 \\
\end{array}$ & Habeas Corpus & $2009.03 .00 .011161-3$ & $\begin{array}{c}\text { Tribunal Regional Federal } \\
\text { da 3- Região }\end{array}$ & BRA 023 \\
\hline $\begin{array}{c}\text { DOC. } \\
57\end{array}$ & Habeas Corpus & $8002-31.2010 .4 .05 .0000$ & \begin{tabular}{|c} 
Tribunal Regional Federal \\
da 5- Região
\end{tabular} & BRA 035 \\
\hline $\begin{array}{c}\text { DOC. } \\
58\end{array}$ & Habeas Corpus & $2007.05 .00 .024422-0$ & \begin{tabular}{|c|}
$\begin{array}{c}\text { Tribunal Regional Federal } \\
\text { da 5a Região }\end{array}$ \\
\end{tabular} & BRA 011 \\
\hline $\begin{array}{c}\text { DOC. } \\
59\end{array}$ & $\begin{array}{l}\text { Revisão } \\
\text { Criminal }\end{array}$ & 420540.2011 .4 .04 .0000 & $\begin{array}{c}\text { Tribunal Regional Federal } \\
\text { da 4- Região }\end{array}$ & BRA 039 \\
\hline $\begin{array}{c}\text { DOC. } \\
60 \\
\end{array}$ & $\begin{array}{l}\text { Revisão } \\
\text { Criminal }\end{array}$ & $\begin{array}{c}17108- \\
17.2010 .4 .05 .0000 \\
\end{array}$ & $\begin{array}{c}\begin{array}{c}\text { Tribunal Regional Federal } \\
\text { da 5- Região }\end{array} \\
\end{array}$ & $\begin{array}{c}\text { BRA } 041 \text { e } \\
\text { BRA } 010\end{array}$ \\
\hline $\begin{array}{c}\text { DOC. } \\
61 \\
\end{array}$ & $\begin{array}{c}\text { Recurso em } \\
\text { Sentido Estrito } \\
\end{array}$ & 6196.78 .2010 .4 .05 .8400 & $\begin{array}{c}\begin{array}{c}\text { Tribunal Regional Federal } \\
\text { da 5- Região }\end{array} \\
\end{array}$ & BRA 036 \\
\hline $\begin{array}{c}\text { DOC. } \\
62\end{array}$ & \begin{tabular}{|c|} 
Recurso em \\
Sentido Estrito \\
\end{tabular} & $\begin{array}{c}11221.27 .2009 .4 .03618- \\
1\end{array}$ & $\begin{array}{c}\text { Tribunal Regional Federal } \\
\text { da 3- Região }\end{array}$ & BRA 026 \\
\hline $\begin{array}{l}\text { DOC. } \\
63\end{array}$ & \begin{tabular}{|c|} 
Embargos de \\
Declaração nos \\
autos da \\
Apelação \\
Criminal \\
\end{tabular} & $2005.03 .99 .009508-0$ & $\begin{array}{l}\text { Tribunal Regional Federal } \\
\text { da 33- Região }\end{array}$ & BRA 069 \\
\hline $\begin{array}{c}\text { DOC. } \\
64\end{array}$ & \begin{tabular}{|c|} 
Embargos de \\
Declaração nos \\
autos da \\
Apelação \\
Criminal \\
\end{tabular} & $2004.61 .06 .00 .4897-4$ & $\begin{array}{l}\text { Tribunal Regional Federal } \\
\text { da 3- Região }\end{array}$ & BRA 025 E 053 \\
\hline $\begin{array}{c}\text { DOC. } \\
65\end{array}$ & $\begin{array}{c}\text { Termo de } \\
\text { Audiência no } \\
\text { Processo } \\
\end{array}$ & $2008.84 .0000 .3092-3$ & $\begin{array}{c}\text { Justiça Federal, Subseção } \\
\text { Judiciária do Estado do } \\
\text { Rio Grande do Norte }\end{array}$ & BRA 052 \\
\hline $\begin{array}{l}\text { DOC. } \\
66\end{array}$ & $\begin{array}{l}\text { Sentença em } \\
\text { Inquérito } \\
\text { Policial } \\
\end{array}$ & $2000.61 .07 .000474-3$ & $\begin{array}{c}\text { Justiça Federal, Subseção } \\
\text { Judiciária do Estado de } \\
\text { São Paulo } \\
\end{array}$ & BRA 017 \\
\hline $\begin{array}{c}\text { DOC. } \\
67\end{array}$ & Sentença & $98.21939-0$ & $\begin{array}{c}\text { Justiça Federal, Subseção } \\
\text { Judiciária do Estado do } \\
\text { Ceará }\end{array}$ & BRA 006 \\
\hline $\begin{array}{c}\text { DOC. } \\
68\end{array}$ & $\begin{array}{l}\text { Apelação } \\
\text { Criminal } \\
\end{array}$ & $2002.83 .0000 .8963-9$ & $\begin{array}{l}\text { Tribunal Regional Federal } \\
\text { da 5- Região }\end{array}$ & BRA 058 \\
\hline $\begin{array}{c}\text { DOC. } \\
69\end{array}$ & Sentença & 4159.81 .2005 .4 .05 .8100 & $\begin{array}{c}\text { Justiça Federal, Subseção } \\
\text { Judiciária do Estado do } \\
\text { Ceará } \\
\end{array}$ & BRA 018 \\
\hline $\begin{array}{c}\text { DOC. } \\
70\end{array}$ & Sentença & $97.01 .04597-1$ & $\begin{array}{c}\text { Justiça Federal, Subseção } \\
\text { Judiciária do Estado de } \\
\text { São Paulo } \\
\end{array}$ & BRA 047 \\
\hline
\end{tabular}




\begin{tabular}{|c|c|c|c|c|}
\hline $\begin{array}{c}\text { DOC. } \\
71\end{array}$ & Sentença & $4447-11.2005 .4 .05 .8300$ & $\begin{array}{c}\text { Justiça Federal, Subseção } \\
\text { Judiciária do Estado de } \\
\text { Pernambuco }\end{array}$ & BRA 014 \\
\hline $\begin{array}{c}\text { DOC. } \\
72\end{array}$ & Sentença & $97.13 .01651-3$ & $\begin{array}{c}\text { Justiça Federal, Subseção } \\
\text { Judiciária do Estado do } \\
\text { Rio Grande do Sul }\end{array}$ & BRA 042 \\
\hline $\begin{array}{l}\text { DOC. } \\
73\end{array}$ & Sentença & 2006.721.00.01111-9 & $\begin{array}{c}\text { Justiça Federal, Subseção } \\
\text { Judiciária do Estado de } \\
\text { Santa Catarina }\end{array}$ & BRA 037 \\
\hline $\begin{array}{c}\text { DOC. } \\
74\end{array}$ & Sentença & $2000.37 .0000 .2913-2$ & $\begin{array}{c}\text { Justiça Federal, Subseção } \\
\text { Judiciária do Estado do } \\
\text { Maranhão }\end{array}$ & BRA 002 \\
\hline $\begin{array}{c}\text { DOC. } \\
75\end{array}$ & Sentença & $2003.83 .0000 .2077-2$ & $\begin{array}{c}\text { Justiça Federal, Subseção } \\
\text { Judiciária do Estado de } \\
\text { Pernambuco }\end{array}$ & BRA 013 \\
\hline $\begin{array}{c}\text { DOC. } \\
76\end{array}$ & Sentença & $1999.61 .8100 .6981-4$ & $\begin{array}{c}\text { Justiça Federal, Subseção } \\
\text { Judiciária do Estado de } \\
\text { Santa Catarina }\end{array}$ & BRA 038 \\
\hline $\begin{array}{l}\text { DOC. } \\
77\end{array}$ & Sentença & $2007.61 .8100 .1663-8$ & $\begin{array}{c}\text { Justiça Federal, Subseção } \\
\text { Judiciária do Estado de } \\
\text { São Paulo } \\
\end{array}$ & BRA 048 \\
\hline $\begin{array}{l}\text { DOC. } \\
78\end{array}$ & Acórdão & $7002.74 .0949-9$ & Origem não informada. & BRA 077 \\
\hline $\begin{array}{l}\text { DOC. } \\
79\end{array}$ & $\begin{array}{l}\text { Apelação } \\
\text { Criminal }\end{array}$ & $2008.5001 .008495-8$ & $\begin{array}{c}\text { Justiça Federal, Subseção } \\
\text { Judiciária do Estado do } \\
\text { Espírito Santo }\end{array}$ & BRA 078 \\
\hline $\begin{array}{l}\text { DOC. } \\
80\end{array}$ & Sentença & 090/2.07.0001774-0 & $\begin{array}{c}\text { Justiça Federal, Subseção } \\
\text { Judiciária do Estado do } \\
\text { Rio Grande do Sul } \\
\end{array}$ & BRA 076 \\
\hline $\begin{array}{c}\text { DOC. } \\
81\end{array}$ & $\begin{array}{l}\text { Apelação } \\
\text { Criminal }\end{array}$ & $2004.81 .00 .006158-0$ & $\begin{array}{c}\text { Tribunal Regional Federal } \\
\text { da 4- Região }\end{array}$ & BRA 008 \\
\hline
\end{tabular}


Apêndice D

\begin{tabular}{|c|c|c|}
\hline \multicolumn{3}{|r|}{ CATEGORIA 1} \\
\hline \multicolumn{3}{|c|}{ PROSTITUIÇÃO COMO EXPLORAÇÃO SEXUAL } \\
\hline DOC. & CORRELAÇÃO & $\begin{array}{l}\text { NARRATIVA DE FRAUDE, ENGANO, COAÇÃO, } \\
\text { EXPLORAÇÃO OU VIOLÊNCIA }\end{array}$ \\
\hline $\begin{array}{c}\text { DOC. } \\
10\end{array}$ & Aproximação semântica & $\begin{array}{l}\text { Dali em diante, as vítimas haviam sido submetidas ao } \\
\text { exercício da prostituição, sobrevivendo a "pão e água" e } \\
\text { sendo obrigadas a fugir da Alemanha para o Brasil. }\end{array}$ \\
\hline $\begin{array}{c}\text { DOC. } \\
12\end{array}$ & Aproximação semântica & $\begin{array}{l}\text { Aduziu o órgão ministerial, em suma, que os denunciados } \\
\text { promoveram a retirada da nacional (...) do território } \\
\text { nacional, com destino à Europa, no dia } 07 / 01 / 2010 \text {, lá } \\
\text { sendo mantida em cárcere privado e para fins de } \\
\text { exploração para a prostituição. }\end{array}$ \\
\hline $\begin{array}{c}\text { DOC. } \\
19\end{array}$ & Aproximação semântica & $\begin{array}{c}\text { (...) operacionalizava esquema de tráfico de mulheres para } \\
\text { a exploração da prostituição na Itália. }\end{array}$ \\
\hline $\begin{array}{c}\text { DOC. } \\
21\end{array}$ & Aproximação semântica & $\begin{array}{c}\text { Ainda segundo a denúncia, a ré, frustrando as expectativas } \\
\text { das jovens, obrigou-as a se dedicarem à prostituição. }\end{array}$ \\
\hline $\begin{array}{c}\text { DOC. } \\
25\end{array}$ & Aproximação semântica & (...) foi forçada à prostituição. \\
\hline $\begin{array}{c}\text { DOC. } \\
27\end{array}$ & Aproximação semântica & $\begin{array}{c}\text { De Paris as moças seguiam para Tel-Aviv/Israel, onde } \\
\text { eram obrigadas a se prostituir. }\end{array}$ \\
\hline $\begin{array}{l}\text { DOC. } \\
28\end{array}$ & Aproximação semântica & $\begin{array}{l}\text { (...) exploração sexual mediante prostituição e fraude. } \\
\text { (...) lá chegando, ditas garotas eram obrigadas a } \\
\text { prostituírem-se. }\end{array}$ \\
\hline $\begin{array}{l}\text { DOC. } \\
30\end{array}$ & Aproximação semântica & $\begin{array}{l}\text { Contudo, foge à competência desta Justiça Federal o } \\
\text { exame dos fatos em tese subsumíveis a outros tipos penais } \\
\text { relacionados à exploração da prostituição. }\end{array}$ \\
\hline $\begin{array}{l}\text { DOC. } \\
33\end{array}$ & $\begin{array}{l}\text { Identidade (sem narrativa } \\
\text { de elementos que } \\
\text { caracterizam tráfico, sob a } \\
\text { perspectiva de Palermo) }\end{array}$ & $\begin{array}{l}\text { 2. Agentes que, no Brasil, (...) participavam de quadrilha } \\
\text { internacional destinada a aliciar mulheres para a } \\
\text { prostituição. } \\
\text { 4. Prova da participação de agentes que mantinham } \\
\text { contato direto com o chefe da quadrilha, que enviava os } \\
\text { estrangeiros para a exploração sexual, sendo } \\
\text { recepcionados pelos agentes, para contato com as moças, } \\
\text { mediante pagamento em dinheiro, além de enviar(em) } \\
\text { mulheres para exercer a prostituição na Alemanha, por } \\
\text { períodos de cerca de três meses. } \\
\text { 5. Autoria e materialidade comprovadas, em face do } \\
\text { conjunto probatório constante dos autos. }\end{array}$ \\
\hline $\begin{array}{c}\text { DOC. } \\
34\end{array}$ & $\begin{array}{l}\text { Identidade (sem narrativa } \\
\text { de elementos que } \\
\text { caracterizam tráfico, sob a } \\
\text { perspectiva de Palermo) }\end{array}$ & $\begin{array}{l}\text { O réu transportou a mulher que ia se prostituir no exterior } \\
\text { até o aeroporto carregando as malas até o check in e diz } \\
\text { que assim ocorreu porque a mala era pesada. Mantinha } \\
\text { contatos com agentes no exterior que exploravam o }\end{array}$ \\
\hline
\end{tabular}




\begin{tabular}{|l|c|} 
exercício da prostituição de mulheres e diz que tal \\
acontecia porque elas pediam e assim sucessivamente com \\
tudo quanto apurado de sua participação nos fatos. (...) \\
Também observo a irrelevância de circunstâncias de \\
interesses e ações livres das mulheres, porque o delito é \\
contra os costumes.
\end{tabular}




\begin{tabular}{|c|c|c|c|c|}
\hline \multicolumn{5}{|c|}{ CATEGORIA 2} \\
\hline \multicolumn{5}{|c|}{ AUXÍLIO À MIGRAÇÃO PARA PROSTITUIÇÃO COMO TRÁFICO DE PESSOAS } \\
\hline DOC. & CORREL. & DISCURSO JUDICIAL & $\begin{array}{l}\text { CONSENT. } \\
\text { IRRELEV. }\end{array}$ & $\begin{array}{c}\text { FRAUDE, } \\
\text { ENGANO, } \\
\text { COAÇÃO } \\
\text { EXPL. OU } \\
\text { VIOL. }\end{array}$ \\
\hline $\begin{array}{c}\text { DOC. } \\
2\end{array}$ & $\begin{array}{c}\text { Associação } \\
\text { genérica }\end{array}$ & $\begin{array}{c}\text { Vê-se que o tipo contém as seguintes condutas: } \\
\text { (...). Tais ações devem visar: à entrada, no } \\
\text { território nacional, de pessoa que nele venha } \\
\text { exercer a prostituição ou a saída de pessoa que } \\
\text { vá exercê-la no exterior. Observa-se que o tipo se } \\
\text { realiza com a promoção, a intermediação ou a } \\
\text { facilitação da entrada (ou saída) de uma ÚNICA } \\
\text { PESSOA, para o exercício da prostituição. Além } \\
\text { disso, o consentimento da vítima e a finalidade de } \\
\text { lucro são indiferentes à tipificação (grifos no } \\
\text { original). } \\
\end{array}$ & Sim & Não \\
\hline $\begin{array}{c}\text { DOC. } \\
4\end{array}$ & $\begin{array}{c}\text { Associação } \\
\text { genérica }\end{array}$ & $\begin{array}{l}\text { Assim, conquanto a sentença não tenha } \\
\text { vislumbrado a conduta típica, o depoimento de } \\
\text { (...) e os diversos indícios objetivos (existência de } \\
\text { dependências apropriadas ao lenocínio; } \\
\text { permanência de várias mulheres; frequência de } \\
\text { homens; fama do local; várias meninas } \\
\text { argentinas) conduzem à certeza de que os fatos } \\
\text { declarados pela vítima são verdadeiros e nessa } \\
\text { condução tipificam a figura denunciada de } \\
\text { promover a entrada no país de mulher que nele } \\
\text { venha a exercer a prostituição. (...) Convém } \\
\text { reiterar ser desnecessária a efetiva prática da } \\
\text { prostituição para que o delito se consuma [sic]. } \\
\text { Forçosa então a condenação. }\end{array}$ & -- & Sim \\
\hline $\begin{array}{c}\text { DOC. } \\
13\end{array}$ & $\begin{array}{c}\text { Associação } \\
\text { genérica }\end{array}$ & $\begin{array}{l}\text { Assim, para apreciação do tráfico de mulheres } \\
\text { simples desimporta a presença ou não do } \\
\text { consentimento das mulheres, não havendo, diante } \\
\text { da anuência, exclusão do crime. } \\
\text { Diante do que foi analisado até então se conclui } \\
\text { que restou comprovada a prática do crime de } \\
\text { tráfico de mulheres pelos denunciados. A autoria } \\
\text { dos réus está bem configurada na conjugação de } \\
\text { esforços e comunhão de vontades nas diligências } \\
\text { por eles efetuadas junto às duas dançarinas, aí } \\
\text { incluído o oferecimento e acerto das quantias a } \\
\text { serem pagas pela prostituição no território } \\
\text { estrangeiro e a disponibilização do transporte até } \\
\text { a Argentina. }\end{array}$ & Sim & Não \\
\hline DOC. & Associação & Sujeito ativo do crime pode ser qualquer pessoa. & Sim & Sim \\
\hline
\end{tabular}




\begin{tabular}{|c|c|c|c|c|}
\hline 14 & genérica & $\begin{array}{c}\text { Sujeito passivo também pode ser qualquer } \\
\text { pessoa, seja do sexo masculino, seja do feminino, } \\
\text { e a coletividade internacional. } \\
\text { A anuência ou consentimento da vítima não } \\
\text { exclui o crime, conforme preceitua o art. 3o-, } \\
\text { alínea "a", do Decreto Legislativo no } 5.017 \text {, de } 12 \\
\text { de março de } 2004 \text {, que internou no ordenamento } \\
\text { jurídico pátrio o "Protocolo Adicional à } \\
\text { Convenção das Nações Unidas contra o } \\
\text { Crime Organizado Transnacional Relativo à } \\
\text { Prevenção, Repressão e Punição do Tráfico de } \\
\text { Pessoas, em Especial, Mulheres e Crianças (...). } \\
\text { (...) } \\
\text { O crime de tráfico internacional de pessoa para } \\
\text { fim de exploração sexual (art. 231, CP) consuma- } \\
\text { se com a entrada ou a saída da pessoa, homem ou } \\
\text { mulher, seja ou não prostituída, do território } \\
\text { nacional, independentemente do efetivo exercício } \\
\text { da prostituição, e, como visto, ainda que conte } \\
\text { com o consentimento da vítima. }\end{array}$ & & \\
\hline $\begin{array}{c}\text { DOC. } \\
15\end{array}$ & $\begin{array}{c}\text { Associação } \\
\text { genérica }\end{array}$ & $\begin{array}{l}\text { (...) caracteriza-se como crime formal, de modo } \\
\text { que sua consumação ocorre com a mera entrada } \\
\text { no Brasil ou a saída da pessoa do território } \\
\text { nacional, não importando a ocorrência do } \\
\text { exercício efetivo da prostituição e nem, na figura } \\
\text { do caput, que consinta ou tenha conhecimento do } \\
\text { fim para o qual está indo ou chegando a } \\
\text { determinado lugar. }\end{array}$ & Sim & Sim \\
\hline $\begin{array}{c}\text { DOC. } \\
17\end{array}$ & $\begin{array}{c}\text { Associação } \\
\text { genérica }\end{array}$ & $\begin{array}{c}\text { O crime de tráfico de mulheres é de natureza } \\
\text { instantânea e se consuma com a entrada, no } \\
\text { território nacional, de mulher que nele venha } \\
\text { exercer a prostituição ou com a saída da mulher } \\
\text { para exercê-la no estrangeiro. Não se exige, } \\
\text { portanto, a efetiva prostituição. } \\
(\ldots) \\
\text { Por fim, pouco releva o argumento da ré de que, } \\
\text { se as ofendidas se prostituíram, teria sido por } \\
\text { vontade própria, na medida em que o delito de } \\
\text { tráfico de mulheres prescinde, para sua } \\
\text { configuração, do efetivo exercício da } \\
\text { prostituição. } \\
(. . .) \\
\text { O dolo da conduta da ré exsurge de sua } \\
\text { participação na prática delitiva, ao intermediar a } \\
\text { contratação de mulheres brasileiras por casas } \\
\text { noturnas suíças para o fim de prostituição. }\end{array}$ & Sim & Sim \\
\hline $\begin{array}{c}\text { DOC. } \\
18\end{array}$ & $\begin{array}{c}\text { Associação } \\
\text { genérica }\end{array}$ & $\begin{array}{l}\text { No caso, o núcleo do tipo previsto no art. } 231 \text { do } \\
\text { Código Penal diz respeito às condutas } \\
\text { consistentes em promover ou facilitar a saída de }\end{array}$ & -- & Não \\
\hline
\end{tabular}




\begin{tabular}{|c|c|c|c|c|}
\hline & & $\begin{array}{c}\text { mulher do território nacional que vá exercer a } \\
\text { prostituição no estrangeiro, consumando-se com } \\
\text { a entrada ou saída da mulher do território } \\
\text { nacional. Segundo Damásio de Jesus não é } \\
\text { necessário que a vítima exerça efetivamente a } \\
\text { prostituição no Brasil ou no estrangeiro. Basta } \\
\text { que a entrada ou saída da mulher do território } \\
\text { nacional seja feita com tal propósito. (in: Direito } \\
\text { Penal. São Paulo: Saraiva, 1996, 3o Vol., Parte } \\
\text { Especial, p. 159). }\end{array}$ & & \\
\hline $\begin{array}{c}\text { DOC. } \\
19\end{array}$ & $\begin{array}{c}\text { Associação } \\
\text { genérica }\end{array}$ & $\begin{array}{l}\text { (...) as testemunhas de acusação, prostitutas que } \\
\text { foram contratadas por (...), relatam em Juízo, de } \\
\text { forma uníssona, que a contratação destinava-se } \\
\text { ao meretrício em Roma, o que aponta } \\
\text { seguramente para o dolo do apelante: (...). } \\
\text { (...) } \\
\text { O tráfico internacional de pessoas para fins de } \\
\text { exploração sexual praticado pelo apelante } \\
\text { também ficou bem delineado, especialmente pelo } \\
\text { teor das conversas interceptadas, nas quais se } \\
\text { observa que o apelante mantinha contato com (...) } \\
\text { referente ao envio de novas prostitutas e às } \\
\text { características que deveriam preencher. Em } \\
\text { 05/10/2007 (...) reclama do declínio dos negócios } \\
\text { e pede a Adriano o envio [de] meninas que } \\
\text { fizessem "tudo", isto é, que se submetessem à } \\
\text { prática sexual em todas as suas vertentes (...). }\end{array}$ & -- & Não \\
\hline $\begin{array}{c}\text { DOC. } \\
20\end{array}$ & $\begin{array}{l}\text { Associação } \\
\text { genérica }\end{array}$ & $\begin{array}{l}\text { Ora, sem maiores delongas, verifico que o crime } \\
\text { imputado à ré é o previsto no art. } 231 \text { do CPB, } \\
\text { que tipifica a conduta de "promover ou facilitar a } \\
\text { entrada, no território nacional, de alguém que } \\
\text { nele venha a exercer a prostituição ou outra } \\
\text { forma de exploração sexual, ou a saída de alguém } \\
\text { que vá exercê-la no estrangeiro". } \\
\text { Da dicção do artigo, facilmente se verifica que a } \\
\text { consumação do delito se dá quando o agente } \\
\text { promove ou facilita a saída de alguém do } \\
\text { território nacional para o estrangeiro com a } \\
\text { finalidade de exercer o meretrício. }\end{array}$ & -- & Sim \\
\hline $\begin{array}{c}\text { DOC. } \\
21\end{array}$ & $\begin{array}{l}\text { Associação } \\
\text { genérica }\end{array}$ & $\begin{array}{l}\text { Também no que diz respeito à consumação do } \\
\text { crime, basta que elas tenham sido ajudadas a sair } \\
\text { do país com o fim de que se prostituíssem, não } \\
\text { importando apurar se a prostituição efetivamente } \\
\text { ocorreu. } \\
\text { (...) ainda que não tivesse ocorrido a prostituição } \\
\text { ou ainda que as meninas quisessem ter-se } \\
\text { prostituído, o crime ter-se-ia consumado do } \\
\text { mesmo modo, pois como já ressaltado, basta a } \\
\text { saída do país com esta finalidade. }\end{array}$ & Sim & Sim \\
\hline
\end{tabular}




\begin{tabular}{|c|c|c|c|c|}
\hline $\begin{array}{c}\text { DOC. } \\
22\end{array}$ & $\begin{array}{c}\text { Associação } \\
\text { genérica }\end{array}$ & $\begin{array}{c}\text { (...) recrutaram as vítimas (...) para exercerem } \\
\text { prostituição na Espanha. } \\
\text { (...) ao tentarem promover a saída das vítimas do } \\
\text { país, cometeram o delito capitulado no artigo } 231 \\
\text { do Código Penal, em sua forma tentada. }\end{array}$ & -- & Não \\
\hline $\begin{array}{c}\text { DOC. } \\
25\end{array}$ & $\begin{array}{c}\text { Associação } \\
\text { genérica }\end{array}$ & \begin{tabular}{|} 
TRÁFICO DE MULHERES (...). CRIME QUE \\
SE CONSUMA COM A MERA FACILITAÇÃO \\
DA SAÍDA DE MULHER DO TERRITÓRIO \\
NACIONAL PARA O EXERCÍCIO DA \\
PROSTITUIÇÃO. IRRELEVÂNCIA DA \\
VONTADE DA VÍTIMA OU DE SUA \\
CONDIÇÃO PRÉVIA DE MERETRIZ NA \\
CARACTERIZAÇÂO DA FORMA BÁSICA. \\
(...) \\
O mero fato de ter emprestado dinheiro à (...) \\
[para] que ela custeasse sua viagem à Espanha, o \\
que está acima de questionamento, já é suficiente \\
para tonalizar o verbo núcleo "facilitar" de que \\
fala o art. 231 do Estatuto repressivo. É \\
inequívoco que (...), com vontade dirigida à \\
prática da ação incriminada, qual seja, a de \\
promover ou facilitar a saída da vítima, tendo \\
consciência de que iria ela entregar-se à \\
prostituição no país a que se destinava, \\
subministrou-lhe os meios materiais necessários a \\
tanto e, mais, prestou-lhe auxílio oferecendo-lhe \\
abrigo em Recife antes do embarque, conforme \\
ela mesma confessou, além de ter indicado-lhe a \\
casa de meretrício (...), cujo proprietário conhece \\
(...). \\
\\
Pouco importa fosse ou não a vítima pessoa \\
dedicada ao meretrício em João Pessoa, ou \\
estivesse ou não ciente da natureza da atividade \\
que desenvolveria em território espanhol. O \\
crime de que aqui se cuida não tem \\
necessariamente a fraude como elemento \\
integrante do tipo. Para sua configuração, inexiste \\
a necessidade de que a vítima tenha sido induzida \\
em erro através da oferta de condição inexistente \\
de trabalho ou algo que não se irá cumprir.
\end{tabular} & Sim & Sim \\
\hline $\begin{array}{c}\text { DOC. } \\
26\end{array}$ & $\begin{array}{c}\text { Associação } \\
\text { genérica }\end{array}$ & \begin{tabular}{|} 
Ora, analisando as declarações acima fica \\
evidenciada a contribuição da ré para a saída da \\
vítima do Brasil com destino à Europa, seja \\
através de ajuda financeira para a compra da \\
passagem, como também quanto ao \\
direcionamento da cidade e local onde a vítima \\
iria trabalhar, coincidindo exatamente na mesma \\
região em que a ré se prostituía anteriormente e \\
\end{tabular} & Sim & Sim \\
\hline
\end{tabular}




\begin{tabular}{|c|c|c|c|c|}
\hline & & $\begin{array}{l}\text { onde seu atual companheiro teria um restaurante. } \\
\text { A conduta da apelante enquadra-se, portanto, } \\
\text { perfeitamente no núcleo do tipo correspondente a } \\
\text { "facilitar" a saída de pessoas para o exterior, cuja } \\
\text { consumação independe até mesmo do } \\
\text { consentimento da vítima, sendo suficiente a ajuda } \\
\text { financeira e o direcionamento ao lugar destinado } \\
\text { à exploração sexual. }\end{array}$ & & \\
\hline $\begin{array}{c}\text { DOC. } \\
34\end{array}$ & $\begin{array}{l}\text { Associação } \\
\text { genérica }\end{array}$ & $\begin{array}{l}\text { O réu transportou a mulher que ia se prostituir no } \\
\text { exterior até o aeroporto carregando as malas até o } \\
\text { check in e diz que assim ocorreu porque a mala } \\
\text { era pesada. Mantinha contatos com agentes no } \\
\text { exterior que exploravam o exercício da } \\
\text { prostituição de mulheres e diz que tal acontecia } \\
\text { porque elas pediam e assim sucessivamente com } \\
\text { tudo quanto apurado de sua participação nos } \\
\text { fatos. (...) } \\
\text { Também observo a irrelevância de circunstâncias } \\
\text { de interesses e ações livres das mulheres, porque } \\
\text { o delito é contra os costumes. }\end{array}$ & Sim & Não \\
\hline $\begin{array}{c}\text { DOC. } \\
36\end{array}$ & $\begin{array}{c}\text { Associação } \\
\text { genérica }\end{array}$ & $\begin{array}{l}\text { Com estes esclarecimentos prévios, volto-me } \\
\text { mais uma vez ao caso em apreço para observar, } \\
\text { em primeiro lugar, que, nos autos, há prova } \\
\text { efetiva de que a denunciada praticou a conduta } \\
\text { descrita no art. } 231, \S 3^{3} \text { - - acima reproduzido - } \\
\text { na medida em que, com vontade livre e } \\
\text { consciente, valendo-se da agência de turismo } \\
\text { efetuou a promoção da saída de mulheres do } \\
\text { território brasileiro para exercerem prostituição } \\
\text { no exterior, com o fito de assim auferir lucro. } \\
\text { Desta forma, presente o primeiro elemento do } \\
\text { fato típico: a conduta. }\end{array}$ & Não & ** 129 \\
\hline
\end{tabular}

${ }^{129}$ Narrativa dúbia, que pode levar à caracterização de ameaça. Faltam elementos que permitam aferir, assertivamente, o ponto. 


\begin{tabular}{|c|c|}
\hline \multicolumn{2}{|r|}{ CATEGORIA 3} \\
\hline \multicolumn{2}{|r|}{ EXERCÍCIO DA PROSTITUIÇÃO COMO DEGRADAÇÃO MORAL } \\
\hline DOC. & CORRELAÇÃO \\
\hline $\begin{array}{c}\text { DOC. } \\
5\end{array}$ & $\begin{array}{l}\text { Além de possuir personalidade voltada à prática reiterada de violações a bens jurídicos } \\
\text { tutelados pelas normas penais, as consequências do delito praticado pelo condenado } \\
\text { (..) são as mais nefastas possíveis: sob sua condenação e ação, faz envolver práticas } \\
\text { incompatíveis e inaceitáveis em pleno século } 21 \text {, que não deixam de ser uma espécie } \\
\text { de "escravidão", uma "escravidão sexual". As mulheres brasileiras são enviadas ao } \\
\text { exterior, mais exatamente para Portugal, para entregar seus corpos com o escopo de } \\
\text { pagarem as passagens aéreas e a estadia já adiantadas e, sobejando, trazendo algo de } \\
\text { volta ao Brasil. / É um procedimento vil e desumano: valer-se da miséria, da pobreza e } \\
\text { da pouca de [sic] oportunidade que esse país oferece a seus próprios nacionais - para } \\
\text { bem viver e/ou subsistir com decência e dignidade, com o fito de ganhar mais, lucrar, } \\
\text { enricar-se. E mais: para construir uma verdadeira organização criminosa, que ilude e } \\
\text { degrada as mulheres nacionais. / Além disso, uma outra consequência, é o fato de se } \\
\text { disseminar no estrangeiro uma ideia errônea e equivocada sobre a mulher brasileira, } \\
\text { dando-lhe nuances pejorativas e vulgares - como se isso fosse a regra. Sem dizer que } \\
\text { tal fato pode passar a impressão que o Estado brasileiro não atua, é conivente com tal } \\
\text { conduta criminosa. / As consequências, pois, são as piores possíveis. O estrangeiro, } \\
\text { notadamente o português é bem vindo ao Brasil, até em face dos vínculos históricos e } \\
\text { etc. No entanto, não se pode mais admitir que ao invés de vir para contribuir para o } \\
\text { progresso e o desenvolvimento do país, aqui venha sangrar-lhe, depauperar-lhe, como } \\
\text { se mercenário fosse. Não se pode mais aceitar esse tipo de comportamento, } \\
\text { especialmente por quem vem de fora. }\end{array}$ \\
\hline $\begin{array}{c}\text { DOC. } \\
9\end{array}$ & "Proposta de trabalho honesto", referência dicotômica ao trabalho sexual. \\
\hline $\begin{array}{c}\text { DOC. } \\
11\end{array}$ & $\begin{array}{l}\text { Por via do tipo penal em apreço, visa-se proteger a moralidade pública sexual, os bons } \\
\text { costumes e também a liberdade sexual, independentemente da discussão acerca do fato } \\
\text { de outros países serem ou não mais liberais no tratamento da exploração do comércio } \\
\text { sexual. }\end{array}$ \\
\hline $\begin{array}{c}\text { DOC. } \\
25\end{array}$ & $\begin{array}{l}\text { A conduta social [da ré] dá conta de ser pessoa de vida fácil e atividades opróbrias. } \\
\text { Quanto à personalidade, revela severos transtornos, delineados pela dificuldade em se } \\
\text { amoldar às regras do lucro moral e honesto. }\end{array}$ \\
\hline $\begin{array}{c}\text { DOC. } \\
35\end{array}$ & $\begin{array}{l}\text { Consideradas as circunstâncias judiciais acima valoradas, e acrescentando a torpeza do } \\
\text { agir da recorrente (gana de obter vantagem econômica com a viagem e atividade } \\
\text { degradante da vítima), o que dá margem ao reconhecimento da agravante do art. 61, II, } \\
\text { "a", do CP (...). }\end{array}$ \\
\hline
\end{tabular}




\begin{tabular}{|c|c|c|c|}
\hline \multicolumn{4}{|c|}{ CATEGORIA 4} \\
\hline \multicolumn{4}{|c|}{ MULHER CISGÊNERO MIGRANTE COMO VÍTIMA } \\
\hline DOC. & CORRELAÇÃO & $\begin{array}{c}\text { FREQUÊNCIA } \\
\text { DO TERMO } \\
\text { VÍTIMA }\end{array}$ & $\begin{array}{l}\text { COMP. DA VÍTIMA COMO REDUTOR DA } \\
\text { PENA-BASE }\end{array}$ \\
\hline $\begin{array}{c}\text { DOC. } \\
2\end{array}$ & Identidade & Alta & $\begin{array}{l}\text { As consequências extrapenais não foram graves e } \\
\text { o comportamento das vítimas facilitou a ação do } \\
\text { agente, já que anuíram no transporte a esta } \\
\text { Capital, para posterior deslocamento para a } \\
\text { Europa (grifos no original). }\end{array}$ \\
\hline $\begin{array}{c}\text { DOC. } \\
4\end{array}$ & Identidade & Alta & 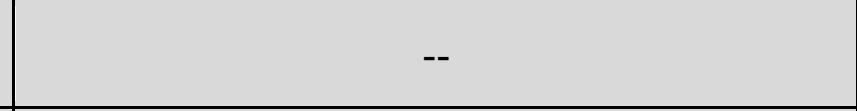 \\
\hline $\begin{array}{c}\text { DOC. } \\
6\end{array}$ & Identidade & Alta & -- \\
\hline $\begin{array}{c}\text { DOC. } \\
7 \\
\end{array}$ & Identidade & Alta & -- \\
\hline $\begin{array}{c}\text { DOC. } \\
8\end{array}$ & Identidade & Alta & -- \\
\hline $\begin{array}{c}\text { DOC. } \\
9\end{array}$ & Identidade & Alta & -- \\
\hline $\begin{array}{c}\text { DOC. } \\
10 \\
\end{array}$ & Identidade & Alta & -- \\
\hline $\begin{array}{c}\text { DOC. } \\
11 \\
\end{array}$ & Proximidade & Média & -- \\
\hline $\begin{array}{c}\text { DOC. } \\
12\end{array}$ & Identidade & Alta & $\begin{array}{c}\text { O comportamento da vítima de certa forma } \\
\text { colaborou para a prática do crime, na medida em } \\
\text { que ela já se prostituía nesta cidade e decidiu ir } \\
\text { para a Europa com o fim de prostituir-se, somente } \\
\text { não sabia que seria mantida em cárcere privado, } \\
\text { achando que teria opção de aceitar ou rejeitar } \\
\text { programas. Essa circunstância deve ser levada em } \\
\text { favor do réu. }\end{array}$ \\
\hline $\begin{array}{c}\text { DOC. } \\
13\end{array}$ & Identidade & Alta & -- \\
\hline $\begin{array}{c}\text { DOC. } \\
14\end{array}$ & Identidade & Alta & -- \\
\hline $\begin{array}{c}\text { DOC. } \\
16\end{array}$ & Identidade & Alta & -- \\
\hline $\begin{array}{c}\text { DOC. } \\
18\end{array}$ & Identidade & Alta & $\begin{array}{l}\text { A vítima contribuiu com a conduta praticada pela } \\
\text { ré, pois vislumbrava ir para o exterior e lá se } \\
\text { prostituir e "ganhar um bom dinheiro" (grifos no } \\
\text { original). }\end{array}$ \\
\hline $\begin{array}{c}\text { DOC. } \\
20\end{array}$ & Identidade & Alta & -- \\
\hline
\end{tabular}




\begin{tabular}{|c|c|c|c|c|}
\hline $\begin{array}{c}\text { DOC. } \\
21\end{array}$ & \multicolumn{2}{|c|}{ Identidade } & Alta & -- \\
\hline \begin{tabular}{|c|} 
DOC. \\
22 \\
\end{tabular} & \multicolumn{2}{|c|}{ Identidade } & Alta & -- \\
\hline $\begin{array}{c}\mathrm{DOC} . \\
24\end{array}$ & \multicolumn{2}{|c|}{ Proximidade } & Baixa & -- \\
\hline $\begin{array}{c}\mathrm{DOC} . \\
25\end{array}$ & \multicolumn{2}{|c|}{ Identidade } & Alta & -- \\
\hline $\begin{array}{c}\text { DOC. } \\
26\end{array}$ & \multicolumn{2}{|c|}{ Identidade } & Alta & -- \\
\hline $\begin{array}{c}\text { DOC. } \\
27\end{array}$ & \multicolumn{2}{|c|}{ Proximidade } & Baixa & -- \\
\hline $\begin{array}{c}\text { DOC. } \\
28\end{array}$ & \multicolumn{2}{|c|}{ Proximidade } & Média & -- \\
\hline $\begin{array}{c}\text { DOC. } \\
36\end{array}$ & \multicolumn{2}{|c|}{ Proximidade } & Baixa & -- \\
\hline \multicolumn{2}{|c|}{ DOC. } & \multicolumn{3}{|c|}{ PAPEL DA NARRATIVA DAS VÍTIMAS } \\
\hline \multicolumn{2}{|c|}{ DOC. 16} & \multicolumn{3}{|c|}{$\begin{array}{l}\text { Crime consumado. Materialidade e autoria comprovadas, sobretudo, com } \\
\text { base nos depoimentos das duas vítimas, que esclarecem acerca da atuação da } \\
\text { ré nas negociações juntamente com o espanhol, levando-as, inclusive, à } \\
\text { polícia federal para tirar passaportes, e de sua estada na Espanha. }\end{array}$} \\
\hline \multicolumn{2}{|c|}{ DOC. 25} & \multicolumn{3}{|c|}{$\begin{array}{l}\text { Em crimes da espécie, praticados, no mais das vezes, na clandestinidade, deve } \\
\text { ser deferida especial atenção para a narrativa da vítima, mormente quando } \\
\text { coerente com as demais circunstâncias em que cometido o delito. Assim, } \\
\text { assume ela caráter preponderante como prova, autorizando, aqui, que se } \\
\text { reconheça o concurso formal, pois tudo nestes autos leva a crer que, } \\
\text { efetivamente, foram encaminhadas outras três mulheres para a Europa, } \\
\text { sempre com o auxílio de (...). Enfatizo que o único interesse da lesada é } \\
\text { apontar os verdadeiros culpados e narrar sua atuação, e não acusar inocentes. } \\
\text { O depoimento de (...) harmônico, estável e seguro desde a fase inquisitória, é } \\
\text { prova quantum satis de que a ré teve também participação ativa na emigração } \\
\text { de (...), pelo que deve incidir a causa especial de aumento contida no art. 70, } \\
\text { caput, do Código Penal. }\end{array}$} \\
\hline \multicolumn{2}{|c|}{ DOC. 26} & \multicolumn{3}{|c|}{$\begin{array}{l}\text { As declarações da vítima neste tipo de delito possuem valor probante } \\
\text { fundamental, vez que são fonte direta de informação de como os fatos } \\
\text { ocorreram. }\end{array}$} \\
\hline
\end{tabular}




\begin{tabular}{|c|c|}
\hline & CATEGORIA 5 \\
\hline & $\begin{array}{l}\text { MIGRAÇÃO PARA A PROSTITUIÇÃO COMO INGENUIDADE OU } \\
\text { VULNERABILIDADE }\end{array}$ \\
\hline DOC. & CORRELAÇÃO \\
\hline $\begin{array}{l}\text { DOC. } \\
2\end{array}$ & "Garotas iludidas". \\
\hline $\begin{array}{l}\text { DOC. } \\
12\end{array}$ & $\begin{array}{l}\text { No caso sub examine, verifica-se que o grau de reprovação da conduta do réu é } \\
\text { intenso, haja vista que se aproveitava de pessoas por quem se dizia apaixonado, para } \\
\text { levá-las consigo ao exterior com fins de prostituição, bem como solicitava-lhes ajuda } \\
\text { para conseguir levar ainda outras pessoas de seu conhecimento, além do que tinha } \\
\text { especial predileção pelas garotas de Natal, Recife e Fortaleza, por serem pobres } \\
\text { (portanto mais vulneráveis) e bonitas (portanto capazes de atrair mais clientes). / (...) } \\
\text { /No que concerne às circunstâncias do delito, já foram acima ponderadas, } \\
\text { considerando que ele se aproveitava de pessoas mais vulneráveis para convencê-las. }\end{array}$ \\
\hline $\begin{array}{l}\text { DOC. } \\
18\end{array}$ & $\begin{array}{l}\text { A ré, de forma livre e consciente, tentou facilitar a saída do país da vítima } \mathrm{D} \text {, para que } \\
\text { esta se prostituísse na cidade de Zaragoza/Espanha, sendo-lhe exigível conduta } \\
\text { diversa. Foi motivada pela possibilidade de que sua prima ingressasse na prostituição } \\
\text { no exterior, a fim de obter lucro fácil. Não há registro de antecedentes criminais. } \\
\text { Personalidade dentro dos padrões normais. De conduta social em desacordo com os } \\
\text { bons costumes. Circunstâncias normais à espécie. As consequências são } \\
\text { desabonadoras, eis que aliciou a vítima nas suas relações de parentesco (prima), } \\
\text { pessoa jovem ( } 24 \text { anos), sem qualificação profissional (faxineira), à procura de uma } \\
\text { segurança financeira e pessoal. }\end{array}$ \\
\hline $\begin{array}{l}\text { DOC. } \\
20\end{array}$ & $\begin{array}{l}\text { (...) O fato de as moças terem conhecimento de que trabalhariam como prostitutas não } \\
\text { afasta a tipicidade da conduta imputada à ré. }\end{array}$ \\
\hline $\begin{array}{l}\text { DOC. } \\
21\end{array}$ & $\begin{array}{l}\text { É que o tipo penal previsto no art. } 231 \text { do CPB tem por finalidade evitar o tráfico de } \\
\text { mulheres, sobretudo quando efetuado por terceiros que visam lucrar às custas de } \\
\text { pessoas menos providas e/ou esclarecidas. }\end{array}$ \\
\hline $\begin{array}{l}\text { DOC. } \\
28\end{array}$ & $\begin{array}{l}\text { Cremos que o passo inicial é perceber a verdadeira situação das mulheres envolvidas, } \\
\text { ou seja, as perceber como vítimas da miséria, da ganância, da nossa própria cultura, } \\
\text { das esperanças desfeitas e dos sonhos nunca realizados, exploradas em suas ilusões de } \\
\text { uma vida melhor e vilipendiadas no corpo e espírito, destroçadas em sua dignidade e } \\
\text { auto-estima (sic), no que pese tentarem demonstrar, muitas vezes, com uma desfaçatez } \\
\text { histriônica, um certo alheamento dos fatos, convencidas de (...) estarem realizando } \\
\text { atividades conscientes e com vontade livre. Verifica-se que muitas das mulheres } \\
\text { envolvidas romantizam suas situações, ainda acreditando que, um dia, "sairão desta } \\
\text { vida" e se casarão com um "gringo" rico e carinhoso, com quem formarão família } \\
\text { respeitável em um vínculo amoroso estável e duradouro, em uma evidente } \\
\text { manifestação de uma adolescência latente, cuja vivência integral não foi permitida } \\
\text { pelo destino. }\end{array}$ \\
\hline $\begin{array}{c}\text { DOC. } \\
36\end{array}$ & "Pessoas humildes e de pouca instrução". \\
\hline
\end{tabular}


Apêndice E

\begin{tabular}{|c|c|c|}
\hline \multicolumn{3}{|c|}{ CONFIRMAÇÃO DE HIPÓTESE } \\
\hline \multicolumn{3}{|c|}{ USOS DO DISCURSO JURÍDICO-PENAL E RISCOS AOS DIREITOS DAS MULHERES } \\
\hline DOC. & ÍNDICE & EXCERTO \\
\hline $\begin{array}{c}\text { DOC. } \\
21\end{array}$ & $\begin{array}{l}\text { Emparelhamento entre os } \\
\text { dizeres da doutrina e o } \\
\text { conteúdo estigmatizador da } \\
\text { mulher migrante e da } \\
\text { prostituição }\end{array}$ & 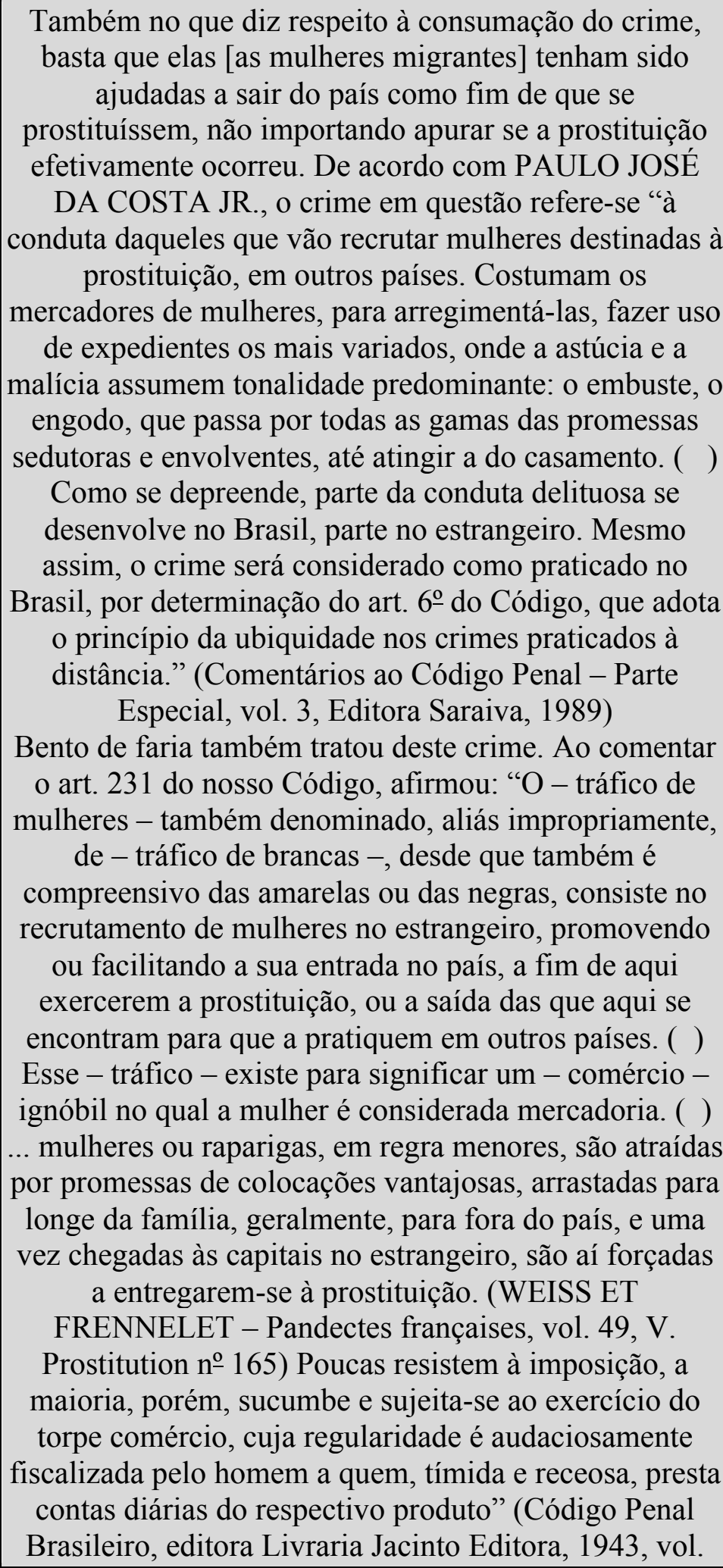 \\
\hline
\end{tabular}




\begin{tabular}{|c|c|c|}
\hline & & V, págs. 128/129). \\
\hline $\begin{array}{c}\text { DOC. } \\
28\end{array}$ & $\begin{array}{l}\text { Discurso de combate à } \\
\text { mercantilização do uso do } \\
\text { corpo como violência a ser } \\
\text { reprimida por controle } \\
\text { policial ostensivo, } \\
\text { especialmente nas fronteiras }\end{array}$ & 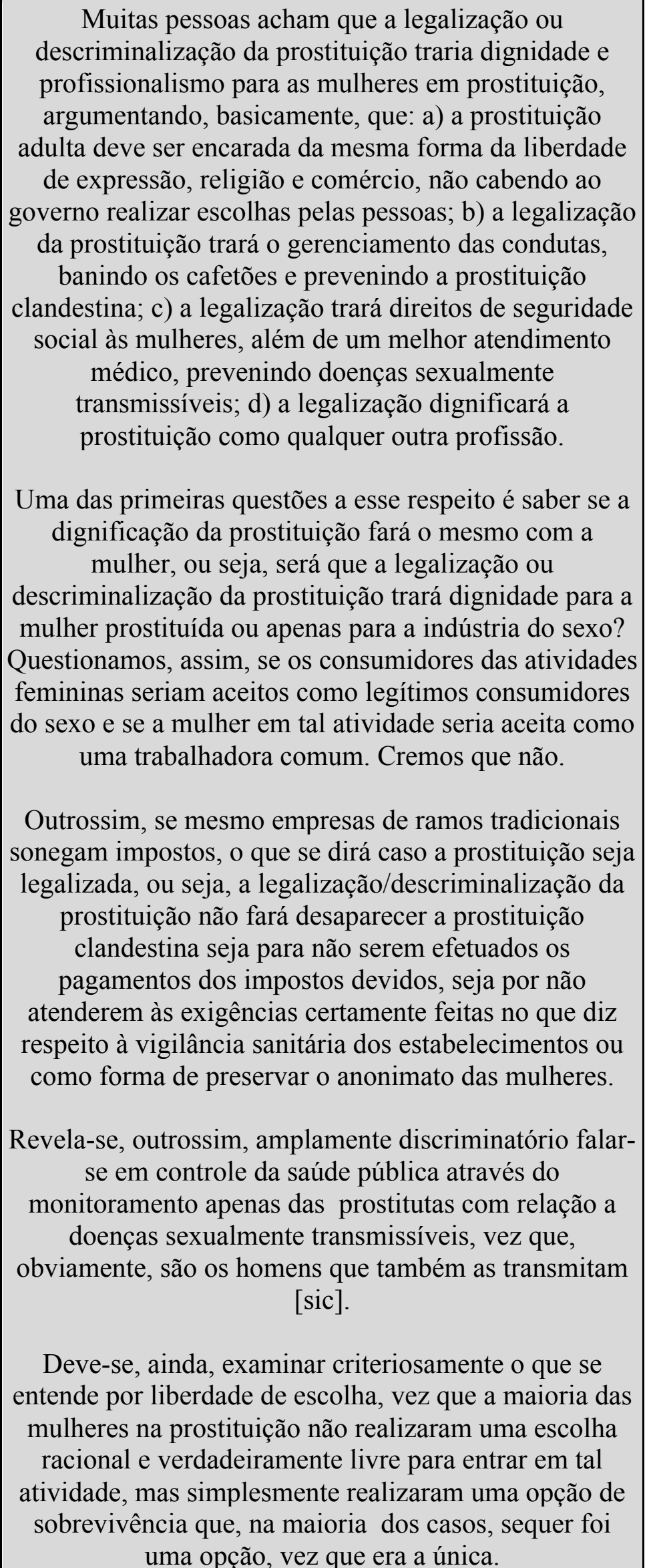 \\
\hline
\end{tabular}


Ademais, legalizar a prostituição parece ser uma maneira simples de dizer aos governantes que eles não precisam se preocupar em melhorar as condições das

populações, vez que sempre haveria a porta da prostituição, abdicando da responsabilidade de promover um decente e aceitável emprego.

No Brasil, por identificar a dignidade da pessoa humana como fundamento do nosso Estado Democrático de Direito (art. 1ํㅡㄴ, III da Constituição de 1988), tal legalização é constitucionalmente defeso [sic], o que não significa deixar de reconhecer a necessidade de amparo e defesa das pessoas exploradas em tais atividades.

Verifica-se, no entanto, que a pobreza é insuficiente para criar uma legião de prostitutas, mas o fazem as percepções ainda silenciosamente cultivadas em nossa sociedade em relação às mulheres, ou seja, aquelas que estabelecem como única coisa de valor na mulher a sua

liberdade sexual que, através de seu corpo, tem se transformado em uma ação vendável. É, pois, a cultura machista ainda vigente em nossa sociedade que partindo da percepção da mulher sem nome, sem família, passado, sem vida e sem vontade, autoriza a prostituição. É nessa cultura invisível que o poder econômico e social cria o silêncio a respeito de quem está sendo explorado, machucado e usado, na penosa constatação de que não se tem a quem recorrer, não se tem a onde ir [sic] e na impressão íntima de que não se é nada. Outro conceito típico de nossa condição de classe média é que as prostitutas são sujas e contagiosas, fontes de tudo o que é ruim e errado, pelo que é vista [sic] como alguém que merece uma punição que a própria vida lhe oferece e não todo tipo de cuidado ou atenção.

Além de se combater a pobreza, do incesto e das violências sexuais sofridas na infância [sic] que empurram a mulher para fora da família e para as profundezas da prostituição, há, pois, que se enfrentar tal cultura, sendo certo que a solução é obviamente política e deve também atingir diretamente os homens que utilizam a prostituição, mas não apenas com penas restritivas da liberdade, mas com pesadas multas e mesmo intervenção estatal, em forma de liquidação forçada, das empresas criadas ou utilizadas de forma preponderante para o tráfico de mulheres, a exemplo da previsão do art. 24 da Lei Ambiental (Lei 9.605, de 12 de fevereiro de 1998). 


\begin{tabular}{|c|c|c|}
\hline & & $\begin{array}{l}\text { Na verdade, cremos que a única prevenção possível seja } \\
\text { a prevenção social, qual seja, a ampliação do acesso à } \\
\text { educação e à saúde, aumento do acesso da mulher ao } \\
\text { mercado de trabalho, maior controle e vigilância nas } \\
\text { regiões de fronteira, com imediato treinamento das } \\
\text { autoridades encarregadas da expedição de passaportes } \\
\text { para prestarem esclarecimentos em entrevistas pessoais } \\
\text { com mulheres suspeitas de futura prostituição. } \\
\text { Disseminação, por meio de todas as formas de mídia, de } \\
\text { informações que auxiliem a prevenir o tráfico e permita } \\
\text { que as pessoas denunciem sua prática, bem como } \\
\text { cartilhas informativas distribuídas por ocasião da } \\
\text { expedição de passaportes ou mesmo impressão de como } \\
\text { realizar tais denúncias nos próprios documentos de } \\
\text { viagem e/ou passaportes são outras medidas simples de } \\
\text { prevenção. }\end{array}$ \\
\hline $\begin{array}{c}\text { DOC. } \\
29\end{array}$ & $\begin{array}{l}\text { Recurso à fala das vítimas } \\
\text { associado à absolvição: o } \\
\text { risco da desproteção }\end{array}$ & $\begin{array}{l}\text { Importa considerar, ainda, que, para a consumação do } \\
\text { delito, é imprescindível que haja a demonstração da } \\
\text { efetiva prática do meretrício pela pessoa traficada, não } \\
\text { bastando a mera consciência pelo agente de que o } \\
\text { ingresso ou a saída da pessoa do território nacional tem } \\
\text { por objetivo o exercício da prostituição. Repita-se, para } \\
\text { a consumação do delito ora em análise, necessário que } \\
\text { ocorra o exercício efetivo da prostituição, tratando-se, } \\
\text { portanto, de crime material. } \\
\text { Neste sentido, leciona o autor Guilherme de Souza } \\
\text { Nucci, in verbis: } \\
\text { "O conceito de prostituição já implica no exercício } \\
\text { habitual do comércio da atividade sexual. É mais uma } \\
\text { modalidade de crime cujo verbo principal exige um } \\
\text { complemento habitual. Para consumar-se, portanto, é } \\
\text { indispensável uma verificação minuciosa do ocorrido } \\
\text { após a entrada da pessoa no território nacional ou depois } \\
\text { que ela saiu, indo para o estrangeiro. Afinal, ainda que a } \\
\text { pessoa ingresse no Brasil para exercer a prostituição, } \\
\text { mas não o faça, inexiste crime. Não é delito formal, mas } \\
\text { material, demandando o efetivo exercício da } \\
\text { prostituição". }\end{array}$ \\
\hline
\end{tabular}




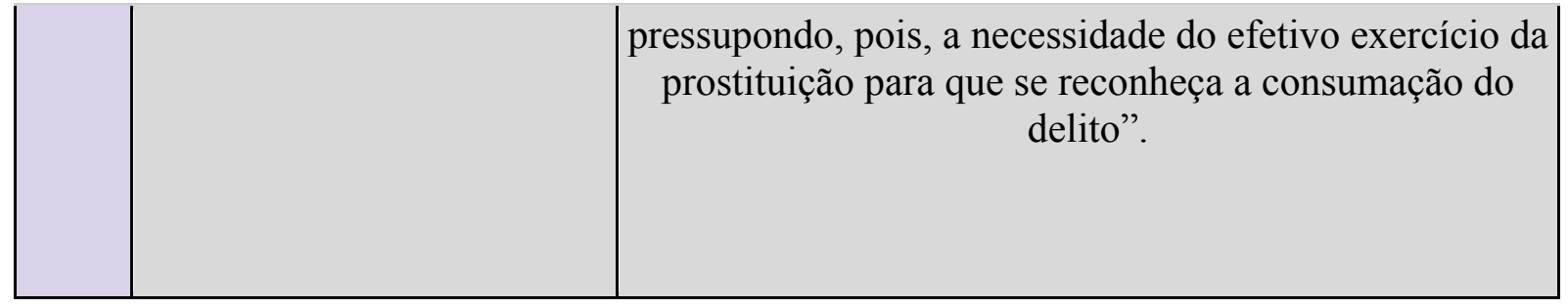

